Marcelo Oliveira Gaspar de Carvalho

Cooperação interorganizacional e apropriação de valor das inovações criadas pelas empresas da indústria de transformação no Brasil

Dissertação de Mestrado

Dissertação apresentada como requisito parcial para obtenção do grau de Mestre pelo Programa de Pós-Graduação em Metrologia (Área de concentração: Metrologia para Qualidade e Inovação) da PUC-Rio.

Orientadora: Prof. ${ }^{a}$ Maria Fatima Ludovico de Almeida 

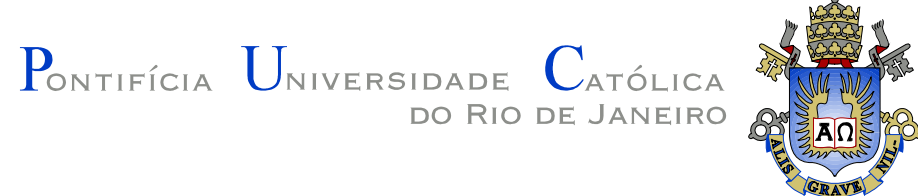

Marcelo Oliveira Gaspar de Carvalho

\title{
Cooperação interorganizacional e apropriação de valor das inovações criadas pelas empresas da indústria de transformação no Brasil
}

Dissertação apresentada como requisito parcial para obtenção do grau de Mestre pelo Programa de Pós-Graduação em Metrologia (Área de concentração: Metrologia para Qualidade e Inovação) da PUC-Rio. Aprovada pela Comissão Examinadora abaixo.

\author{
Profa. Maria Fatima Ludovico de Almeida \\ Orientadora \\ Programa de Pós-Graduação em Metrologia - PUC-Rio
}

Prof. Carlos Augusto Caldas de Moraes Mestrado em Economia Empresarial Universidade Cândido Mendes - UCAM

Prof. Waldir Jesus de Araújo Lobão Escola Nacional de Ciências Estatísticas - ENCE Instituto Brasileiro de Geografia e Estatística - IBGE

Rio de Janeiro, 08 de maio de 2019 
Todos os direitos reservados. É proibida a reprodução total ou parcial do trabalho sem autorização da universidade, do autor e de sua orientadora.

\section{Marcelo Oliveira Gaspar de Carvalho}

Graduado em Engenharia Mecânica pela Universidade do Estado do Rio de Janeiro (1987). Possui larga experiência nas áreas de Tecnologia Industrial Básica, tendo coordenado os Laboratórios no SENAI - CETIQT - Centro de Tecnologia da Indústria Química e Têxtil. Atualmente é mestrando do Programa de Pós-Graduação em Metrologia da PUC-Rio.

Ficha Catalográfica

Carvalho, Marcelo Oliveira Gaspar de

Cooperação interorganizacional e apropriação de valor das inovações criadas pelas empresas da indústria de transformação no Brasil / Marcelo Oliveira Gaspar de Carvalho Orientadora: Maria Fatima Ludovico de Almeida. - 2019.

$191 \mathrm{f}$; $30 \mathrm{~cm}$

Dissertação (mestrado)-Pontifícia Universidade Católica do Rio de Janeiro, Centro Técnico Científico, Programa de Pós-Graduação em Metrologia para a Qualidade e Inovação, 2019.

Inclui bibliografia

1. Metrologia - Teses. 2. Inovação tecnológica. 3. Regime de apropriabilidade. 4. Modelo econométrico logit. 5. Pintec. I. Maria Fatima Ludovico de Almeida. II. Pontifícia Universidade Católica do Rio de Janeiro. Centro Técnico Científico. Programa de Pós-Graduação em Metrologia para a Qualidade e Inovação. III. Título. 


\section{Agradecimentos}

Embora uma dissertação seja, por sua finalidade acadêmica, uma tarefa individual, tal trabalho não teria sido concluído sem o apoio de várias pessoas tão especiais que estão ao meu lado e as que já, não mais presentes fisicamente, mas que certamente, em espírito, deram a inspiração necessária para que eu chegasse à sua conclusão.

Em primeiro lugar, não posso deixar de agradecer a Deus, maior fonte de força espiritual, que permitiu uma caminhada de Fé, Dedicação e Ânimo para que todos os percalços fossem removidos.

À minha esposa, Myriam, grande incentivadora e responsável por eu ter retornado ao Programa de Pós-graduação em Metrologia (Pós-MQI) da PUC-Rio, após dez anos de uma primeira tentativa não conclusiva e de ter acompanhado todo este novo processo sendo uma luz no meu caminho. Realmente um exemplo de perseverança para mim e de garra profissional. Escreveria uma "tese" para te agradecer, mas a frase "Amor da minha vida", resume todo o meu sentimento de agradecimento.

Aos meus pais (in memoriam), por todas as bênçãos e torcida, que certamente dispenderam sobre mim onde quer que estejam, para que eu não os decepcionasse em toda essa trajetória.

À minha querida orientadora, professora e amiga para sempre, Professora Maria Fatima Ludovico de Almeida, que, com sua competência cognitiva e holística, permitiu traduzir os meus anseios temáticos em um trabalho gratificante, que certamente abrirá novas oportunidades na minha vida profissional. Muito obrigado por ter me colocado no rumo certo, quando necessário, sem nunca me desmotivar.

Ao Prof. Maurício Nogueira Frota, por ter mais uma vez acolhido ao meu pedido de ingresso no mestrado e ao Prof. Carlos Hall, por ter viabilizado o meu sonho. 
Aos meus familiares e amigos pelo apoio incondicional que me deram, especialmente aos meus "pets" que estiveram sempre, literalmente, aos meus pés, nas incansáveis noites ao longo da elaboração deste trabalho.

Desejo igualmente agradecer a todos os meus professores, assistentes, equipe de apoio e colegas do Mestrado em Metrologia da PUC-Rio, cujo apoio e amizade estiveram sempre presentes em todos os momentos dessa trajetória.

Ao Instituto Brasileiro de Geografia e Estatística (IBGE), pela autorização do uso dos microdados da Pesquisa de Inovação Tecnológica (Pintec 2014) e, em especial, a José Eduardo de Oliveira Trindade pelo apoio institucional e técnico na realização do estudo empírico objeto desta pesquisa.

Aos Professores membros da banca examinadora pelas suas valiosas análises e recomendações, que muito contribuíram para a revisão e melhoria desta dissertação.

O presente trabalho foi realizado com apoio da Coordenação de Aperfeiçoamento de Pessoal de Nível Superior - Brasil (CAPES) - Código de Financiamento 001. 


\section{Resumo}

Carvalho, Marcelo Oliveira Gaspar de; Almeida, Maria Fatima Ludovico de. Cooperação interorganizacional e apropriação de valor das inovações criadas pelas empresas da indústria de transformação no Brasil. Rio de Janeiro, 2019. 191 p. Dissertação de Mestrado - Programa de PósGraduação em Metrologia, Pontifícia Universidade Católica do Rio de Janeiro.

O objetivo da dissertação é analisar e comparar a influência de diferentes tipos de parceiros em arranjos cooperativos para projetos de PD\&I sobre a apropriação de valor pelas empresas inovadoras da indústria de transformação no Brasil, considerando-se condições ambientais distintas, como nível de intensidade tecnológica e força do regime de apropriabilidade dos setores em que atuam, bem como características internas, como tamanho da empresa e capacidade para cooperar em projetos de PD\&I (focalizando inovações de produto e/ou processo). A fonte de dados é a Pesquisa Nacional de Inovação (Pintec 2014), realizada pelo Instituto Brasileiro de Geografia e Estatística (IBGE). A pesquisa pode ser considerada descritiva e aplicada. A metodologia adotada compreende pesquisa bibliográfica sobre inovação; mecanismos de apropriação de valor; cooperação interorganizacional para inovação e classificações tecnológicas, destacando-se a classificação de intensidade tecnológica proposta pela Organização para a Cooperação e Desenvolvimento Econômico (OCDE); pesquisa documental referente à Classificação CNAE e ao Manual da Pintec 2014, ambas divulgadas pelo IBGE; análise de conteúdo para classificar as atividades econômicas das empresas inovadoras da indústria de transformação (respondentes da Pintec 2014), segundo quatro níveis de intensidade tecnológica e regime de apropriabilidade dos setores em que atuam e três faixas de pessoal alocado; solicitação ao IBGE de acesso aos microdados não desidentificados da Pintec 2014; e desenvolvimento de modelos econométricos logit para os doze agrupamentos de empresas, classificadas por intensidade tecnológica/força do regime de apropriabilidade do setor e por faixa de pessoal ocupado. A utilização dos microdados da Pintec 2014 para analisar a influência da cooperação interorganizacional sobre a apropriação de valor pelas empresas inovadoras da indústria de transformação no Brasil em diferentes condições ambientais conferem à pesquisa um caráter original, uma vez que os estudos anteriores baseados em Pesquisas Nacionais de Inovação não exploraram essa abordagem metodológica.

\section{Palavras-chave}

Metrologia; inovação tecnológica; regime de apropriabilidade; cooperação interorganizacional; modelo de regressão logística; Pintec; Brasil. 


\section{Abstract}

Carvalho, Marcelo Oliveira Gaspar de; Almeida, Maria Fatima Ludovico de. Interorganizational cooperation and value appropriation of innovations created by manufacturing companies in Brazil. Rio de Janeiro, 2019. 191 p. Dissertação de Mestrado - Programa de PósGraduação em Metrologia, Pontifícia Universidade Católica do Rio de Janeiro.

This dissertation aims to analyze and compare the influence of different types of partners in cooperative arrangements for RD\&I projects on the appropriation of value by innovative companies of the transformation industry in Brazil, considering different environmental conditions, such as the level of technological intensity and strength of the appropriability regime of the sectors in which they operate, as well as internal characteristics such as company size and its capacity to cooperate in RD\&I projects (focusing on product and/or process innovations). The primary data source is the National Innovation Survey (Pintec), conducted by the Brazilian Institute of Geography and Statistics (IBGE). The research can be considered descriptive and applied. The methodology adopted includes bibliographic research on innovation; value creation and value appropriation mechanisms; and technological classifications, highlighting the classification of sectoral technological intensity proposed by the Organization for Economic Cooperation and Development (OECD); documentary analysis concerning the Brazilian Classification of Economic Activities (CNAE) and Pintec 2014, both published by IBGE; content analysis to classify the economic activities of the respondent companies, according to sectoral technological intensity, appropriability regime of the sectors in which they operate and number of employees; request to IBGE for access to microdata of Pintec 2014; development of logit econometric models for the companies classified by sector technological intensity/strength of the appropriability regime, and by number of employees (micro and small, medium and large companies). The use of microdata from Pintec 2014 to analyze and compare the influence of different types of partners in cooperative arrangements for RD\&I projects on the appropriation of value by innovative companies under different environmental conditions give the research an original character, since previous studies based on National Innovation Surveys have not explored this methodological approach.

\section{Keywords}

Metrology; technological innovation; appropriability regime; interorganizational cooperation; logistic regression models; Pintec; Brazil. 


\section{Sumário}

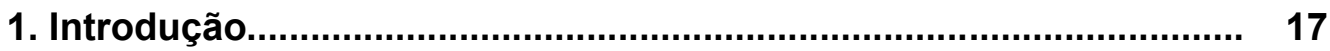

1.1 Definição do problema de pesquisa................................................... 20

1.2 Objetivos: geral e específicos..................................................... 20

1.3 Metodologia.......................................................................... 21

1.3.1 Fase exploratória e descritiva..................................................... 22

1.3.2 Fase de pesquisa aplicada.......................................................... 26

1.3.3 Fase conclusivo-proporsitiva................................................... 28

1.4 Estrutura da dissertação....................................................... 28

2. Inovação, cooperação interorganizacional e apropriação de valor pela criação de inovações .................................................................. 29

2.1 Inovação: conceitos, definições e tipologias.................................... 29

2.2 Cooperação interorganizacional para inovação................................. 35

2.3 Mecanismos para apropriação de valor: formais e não formais........... 36

2.4 Regime de apropriabilidade: fatores determinantes do uso e da eficácia dos mecanismos para apropriação de valor................................ 38

2.5 Decisões sobre o uso de mecanismos para apropriação de valor....... 41

2.5.1 Segredo industrial............................................................... 41

2.5.2 Complexidade tecnológica.......................................................... 42

2.5.3 Tempo de liderança frente aos concorrentes ................................. 43

2.5.4 Patentes, marcas e outros métodos formais de proteção................. 45

2.5.5. Ativos complementares............................................................ 47

2.6 Arquitetura setorial, intensidade tecnológica e uso de ativos complementares.................................................................. 49

2.7 Análise dos estudos empíricos sobre cooperação interorganizacional em projetos de inovação e apropriação de valor.

3. Principais características da inovação na indústria de transformação no Brasil........................................................................ 63

3.1 Panorama geral da indústria brasileira de transformação no Brasil..... 63

3.2 Indicadores da inovação na indústria de transformação...................... 68

3.2.1 Caracterização das empresas inovadoras .................................. 71

3.2.2 Atividades inovativas.............................................................. 74

3.2.3 Cooperação interorganizacional para inovação............................... 77

3.2.4 Impactos das inovações geradas .......................................... 80 
4. Estudo empírico: cooperação interorganizacional e apropriação de valor das inovações geradas pelas empresas inovadoras da indústria de transformação no Brasil

86

4.1 Definição dos objetivos do estudo ................................................. 86

4.2 Hipóteses de pesquisa............................................................... 87

4.3 Métodos adotados................................................................ 91

4.3.1 Coleta de dados: Pintec 2014 como fonte de dados secundários.... 92

4.3.2 Construção da amostra estratificada do estudo............................... 94

4.3.3 Conteúdo da informação.......................................................... 98

4.3.4 Modelagem de dados e inferência estatística................................ 102

4.4 Síntese dos aspectos metodológicos.............................................. 115

4.5 Análise dos resultados............................................................... 115

4.5.1 Análise da influência dos parceiros em arranjos cooperativos sobre a apropriação de valor das inovações geradas: agrupamento setorial AT/FO

4.5.2 Análise da influência dos parceiros em arranjos cooperativos sobre a apropriação de valor das inovações geradas: agrupamento setorial AT/FR

4.5.3 Análise da influência dos parceiros em arranjos cooperativos sobre a apropriação de valor das inovações geradas: agrupamento setorial $\mathrm{BT} / \mathrm{FO}$

4.5.4 Análise da influência dos parceiros em arranjos cooperativos sobre a apropriação de valor das inovações geradas: agrupamento setorial BT/FR

4.6 Síntese dos resultados do estudo empírico.

5. Conclusões

Referências bibliográficas nas regressões logísticas com os microdados da Pintec 2014. 


\section{Lista de figuras}

Figura 1.1 - Desenho da pesquisa, seus componentes e métodos....... 22

Figura 1.2 - Mapa conceitual da pesquisa............................................ 27

Figura 2.1 - Modelo conceitual da influência de diferentes parceiros em arranjos cooperativos sobre a apropriação de valor das inovações geradas pelas empresas da indústria de transformação no Brasil

Figura 3.1 - Participação da indústria de transformação no PIB: Brasil1948 - 2018...

Figura 3.2 - Distribuição do PIB por setores da economia: Brasil 2017

Figura 3.3 - Taxa de empresas que implementaram inovações, por atividade da indústria de transformação (\%): Brasil - 2014

Figura 4.1 - Modelo conceitual proposto com as hipóteses de pesquisa 


\section{Lista de quadros}

Quadro 1.1 - Cooperação interorganizacional para inovação em diferentes condições ambientais

Quadro 4.1 - Síntese das hipóteses associadas à influência da cooperação interorganizacional na apropriação de valor das inovações geradas pelas empresas de transformação no Brasil....

Quadro 4.2 - Definição das variáveis dependentes do estudo, códigos, escalas de medidas e valores.

Quadro 4.3 - Definição das variáveis de controle do estudo, códigos, escalas de medidas e valores.

Quadro 4.4 - Definição das variáveis explanatórias do estudo, códigos, escalas de medidas e valores.

Quadro 4.5 - Resultados das hipóteses do modelo $Y_{A M B}$ referente ao estrato 'BT/FO - médias empresas': análise de um caso concreto.

Quadro 4.6 - Síntese dos aspectos metodológicos do estudo empírico..

Quadro 4.7 - Resultados das hipóteses de pesquisa dos modelos $Y_{M E R C}$ referentes aos estratos AT/FO.

Quadro 4.8 - Resultados das hipóteses de pesquisa dos modelos $Y_{P R O D}$ referentes aos estratos AT/FO

Quadro 4.9 - Resultados das hipóteses de pesquisa dos modelos $Y_{A M B I}$ referentes aos estratos AT/FO.

Quadro 4.10 - Resultados das hipóteses de pesquisa dos modelos $Y_{S O C I}$ referentes aos estratos AT/FO.

Quadro 4.11 - Resultados das hipóteses de pesquisa dos modelos $Y_{R E G U}$ referentes aos estratos AT/FO.

Quadro 4.12 - Resultados das hipóteses de pesquisa dos modelos $Y_{M E R C}$ referentes aos estratos AT/FR.

Quadro 4.13 - Resultados das hipóteses de pesquisa dos modelos $Y_{P R O D}$ referentes aos estratos AT/FR.

Quadro 4.14 - Resultados das hipóteses de pesquisa dos modelos $Y_{A M B I}$ referentes aos estratos AT/FR.

Quadro 4.15 - Resultados das hipóteses de pesquisa dos modelos $Y_{\text {SOCI }}$ referentes aos estratos AT/FR.

Quadro 4.16 - Resultados das hipóteses de pesquisa dos modelos $Y_{R E G U}$ referentes aos estratos AT/FR.

Quadro 4.17 - Resultados das hipóteses de pesquisa dos modelos $Y_{M E R C}$ referentes aos estratos BT/FO. 
Quadro 4.18 - Resultados das hipóteses de pesquisa dos modelos $Y_{P R O D}$ referentes aos estratos BT/FO.

Quadro 4.19 - Resultados das hipóteses de pesquisa dos modelos $Y_{A M B I}$ referentes aos estratos BT/FO.

Quadro 4.20 - Resultados das hipóteses de pesquisa dos modelos $Y_{S O C I}$ referentes aos estratos BT/FO.

Quadro 4.21 - Resultados das hipóteses de pesquisa dos modelos $Y_{R E G U}$ referentes aos estratos BT/FO.

Quadro 4.22 - Resultados das hipóteses de pesquisa dos modelos $Y_{M E R C}$ referentes aos estratos BT/FR.

Quadro 4.23 - Resultados das hipóteses de pesquisa dos modelos $Y_{P R O D}$ referentes aos estratos BT/FR.

Quadro 4.24 - Resultados das hipóteses de pesquisa dos modelos $Y_{A M B I}$ referentes aos estratos BT/FR.

Quadro 4.25 - Resultados das hipóteses de pesquisa dos modelos $Y_{\text {SOCI }}$ referentes aos estratos BT/FR.

Quadro 4.26 - Resultados das hipóteses de pesquisa dos modelos $Y_{R E G U}$ referentes aos estratos AT/FR.

Quadro 4.27 - Síntese dos resultados do estudo empírico, segundo enquadramento conceitual da pesquisa.... 


\section{Lista de tabelas}

Tabela 3.1 - Valor adicionado da indústria de transformação por setor: Brasil - 2016 .

Tabela 3.2 - Estabelecimentos da indústria de transformação por setor: Brasil - 2017 .....

Tabela 3.3 - Empresas da indústria de transformação que implementaram inovação de produto e/ou processo ou com projetos: Brasil - 2014 .

Tabela 3.4 - Dispêndios realizados em atividades internas de P\&D pelas empresas da indústria de transformação: Brasil 2014

Tabela 3.5 - Empresas da indústria de transformação que implementaram inovação de produto e/ou processo ou com projetos por faixa de pessoal ocupado: Brasil - 2014

Tabela 3.6 - Grau de novidade do principal produto e/ou principal processo nas empresas da indústria de transformação que implementaram inovações: Brasil - 2014.

Tabela 3.7 - Empresas que implementaram inovações, por grau de importância das atividades inovativas desenvolvidas, segundo atividades da indústria de transformação: Brasil -2014 .

Tabela 3.8 - Empresas que implementaram inovações, total e com relações de cooperação com outras organizações, por grau de importância da parceria, segundo atividades da indústria de transformação: Brasil - 2014 .

Tabela 3.9 - Empresas que implementaram inovações, por grau de importância do impacto causado, segundo atividades da indústria de transformação: Brasil - 2014 .

Tabela 4.1 - Número de empresas selecionadas para a PINTEC, por estrato, segundo as atividades da indústria, do setor de eletricidade e gás e dos serviços selecionados: Brasil 2014

Tabela 4.2 - Empresas da indústria de transformação que implementaram inovações e com relações de cooperação com outras organizações: Brasil - 2014 ...

Tabela 4.3 - Classificação dos setores da indústria de transformação pela intensidade tecnológica e força do regime de apropriabilidade: Brasil - 2008 .....

Tabela 4.4 - Caracterização da amostra e proporção entre observações e variáveis explanatórias do estudo empírico. 
Tabela 4.5 - Resultados do modelo nulo $Y_{A M B I}$ referente ao estrato 'BT/FO - Médias empresas': passo 0 da estimação Stepwise no caso concreto...

Tabela 4.6 - Significância das variáveis explanatórias para entrada no modelo $Y_{A M B I}$ referente ao estrato 'BT/FO - Médias empresas': análise no caso concreto.

Tabela 4.7 - Resultados da entrada de $X_{E M P R}$ no modelo $Y_{A M B}$ referente ao estrato BT/FO - Médias empresas: passo 1 da estimação Stepwise no caso concreto.

Tabela 4.8 - Significância das variáveis explanatórias após entrada de $X_{E M P R}$ no modelo $Y_{A M B I}$ referente ao estrato 'BT/FO Médias empresas': análise no caso concreto.

Tabela 4.9 - Resultados da entrada de $X_{E M P R}$ no modelo $Y_{A M B I}$ referente ao estrato 'BT/FO - Médias empresas': passo 2 da estimação Stepwise no caso concreto.

Tabela 4.10 - Significância das variáveis explanatórias após entrada de $X_{E M P R}$ e $X_{I C T S}$ no modelo $Y_{A M B I}$ referente ao estrato 'BT/FO - Médias empresas' : análise no caso concreto....

Tabela 4.11 - Resultados da entrada de $X_{E M P R}$ no modelo $Y_{A M B I}$ referente ao estrato 'BT/FO - Médias empresas': passo 3 da estimação Stepwise no caso concreto.

Tabela $4.12-$ Significância das variáveis explanatórias após entrada de $X_{E M P R}, X_{I C T S}$ e $X_{C E R T}$ no modelo $Y_{A M B I}$ referente ao estrato 'BT/FO - Médias empresas': análise no caso concreto.

Tabela 4.13 - Resultados das regressões logísticas para os modelos estimados $Y_{M E R C}$ referentes aos estratos AT/FO

Tabela $4.14-$ Resultados das regressões logísticas para os modelos estimados $Y_{P R O D}$ referentes aos estratos AT/FO.....

Tabela $4.15-$ Resultados das regressões logísticas para os modelos estimados $Y_{A M B /}$ referentes aos estratos AT/FO.

Tabela $4.16-$ Resultados das regressões logísticas para os modelos estimados $Y_{\text {soc }}$ referentes aos estratos AT/FO.

Tabela 4.17 - Resultados das regressões logísticas para os modelos estimados $Y_{R E G U}$ referentes aos estratos AT/FO.

Tabela 4.18 - Resultados das regressões logísticas para os modelos estimados $Y_{M E R C}$ referentes aos estratos AT/FR.

Tabela 4.19 - Resultados das regressões logísticas para os modelos estimados $Y_{P R O D}$ referentes aos estratos AT/FR

Tabela 4.20 - Resultados das regressões logísticas para os modelos estimados $Y_{A M B I}$ referentes aos estratos AT/FR

Tabela 4.21 - Resultados das regressões logísticas para os modelos estimados $Y_{\text {socl }}$ referentes aos estratos AT/FR.....

Tabela $4.22-$ Resultados das regressões logísticas para os modelos estimados $Y_{R E G U}$ referentes aos estratos AT/FR.

Tabela $4.23-$ Resultados das regressões logísticas para os modelos estimados $Y_{M E R C}$ referentes aos estratos BT/FO

Tabela $4.24-$ Resultados das regressões logísticas para os modelos estimados $Y_{P R O D}$ referentes aos estratos BT/FO.

Tabela $4.25-$ Resultados das regressões logísticas para os modelos estimados $Y_{A M B}$ referentes aos estratos BT/FO. 
Tabela 4.26 - Resultados das regressões logísticas para os modelos estimados $Y_{\text {socl }}$ referentes aos estratos BT/FO.......

Tabela 4.27 - Resultados das regressões logísticas para os modelos estimados $Y_{R E G U}$ referentes aos estratos BT/FO.

Tabela 4.28 - Resultados das regressões logísticas para os modelos estimados $Y_{M E R C}$ referentes aos estratos BT/FR

Tabela 4.29 - Resultados das regressões logísticas para os modelos estimados $Y_{P R O D}$ referentes aos estratos BT/FR

Tabela 4.30 - Resultados das regressões logísticas para os modelos estimados $Y_{A M B I}$ referentes aos estratos BT/FR.

Tabela 4.31 - Resultados das regressões logísticas para os modelos estimados $Y_{\text {soc }}$ referentes aos estratos BT/FR.

Tabela 4.32 - Resultados das regressões logísticas para os modelos estimados $Y_{\text {REGU }}$ referentes aos estratos BT/FR. 


\section{Abreviaturas}

C\&T-Ciência e Tecnologia

CNAE - Classificação Nacional das Atividades Econômicas

DPI - Direitos de propriedade intelectual

FIESP - Federação das Indústrias do Estado de São Paulo

IEDI - Instituto de Estudos para o Desenvolvimento Industrial

IBGE - Instituto Brasileiro de Geografia e Estatística

ICT - Instituição de Ciência e Tecnologia

MEI - Movimentação Empresarial pela Inovação

OCDE - Organização para a Cooperação e Desenvolvimento Econômico

PD\&I - Pesquisa, Desenvolvimento e Inovação

PIB - Produto Interno Bruto

PINTEC - Pesquisa Nacional de Inovação

Pós-MQI - Programa de Pós-graduação em Metrologia da PUC-Rio

PUC-Rio - Pontifícia Universidade Católica do Rio de Janeiro

SAS - Statistical Analysis Software

VA - Valor adicionado 


\section{Introdução}

A cooperação interorganizacional entre empresas inovadoras e outras organizações tem sido foco de um debate mais amplo sobre Sistemas Nacionais de Inovação e Políticas Públicas de Ciência e Tecnologia (C\&T) e Industrial em diversos países e regiões. Nesse contexto, discute-se que a força do regime de apropriabilidade e a intensidade tecnológica dos setores em que as empresas atuam são fatores ambientais que influenciam significativamente a capacidade das empresas inovadoras em obter efetivamente os lucros advindos de suas inovações.

Esses fatores relacionam-se à natureza do conhecimento existente na inovação (se tácito ou codificado), à eficácia dos mecanismos de proteção do conhecimento gerado e ao acesso das empresas a ativos complementares ${ }^{1}$. Destacase na presente pesquisa a importância da cooperação interorganizacional em projetos de inovação como um dos meios de acesso das empresas inovadoras a ativos complementares estratégicos, na perspectiva de materialização do potencial de apropriação de valor pela criação de suas inovações.

No Brasil, desde 1986, observa-se uma significativa perda de participação da indústria de transformação no PIB do país, configurando-se um processo de desindustrialização. De acordo com dados do IBGE e estimativas da Federação das Indústrias do Estado de São Paulo (Fiesp), a participação da indústria no PIB declinou quase 10 pontos percentuais ao longo do último período, atingindo, em 2018, a marca dos 11,3\% (Fiesp, 2019).

Metade dos setores da indústria de transformação (alimentos, bebidas; fumo; têxteis; vestuário; couro e calçados; móveis e madeira; metalurgia e produtos de metal; química e petroquímica; máquinas e equipamentos) foram responsáveis por

\footnotetext{
Adota-se nesta pesquisa a abordagem teórica de Teece (1986; 1988; 1992; 2006; 2016) referente a ativos complementares e cooperação interorganizacional. Segundo esse autor, a inovação, para ter seu potencial de ganhos econômicos materializado, requer outros ativos ou capacitações, denominados de ativos complementares. Tais ativos podem ser genéricos, especializados e co-especializados.
} 
mais de 4/5 da perda de participação dessa indústria no PIB entre 1970 e 2016 (IEDI, 2019b).

Os setores de menor intensidade tecnológica (vestuário; couro e calçados; têxteis; minerais não metálicos; móveis e produtos de madeira) seguiram o padrão internacional e perderam participação no PIB, à medida que a renda per capita do país aumentou. Em conjunto, os setores de maior intensidade tecnológica perderam $40 \%$ de peso no PIB desde 1980. Isso é muito crítico e desfavorável ao desenvolvimento do país, considerando-se o dinamismo tecnológico desses setores em nível mundial.

Um dos impulsionadores-chave para a retomada do crescimento da indústria de transformação brasileira e um posicionamento competitivo superior no mercado global é a inovação. Nessa perspectiva, desde 2008, a Confederação Nacional da Indústria (CNI) reúne líderes empresariais, associações industriais e federações estaduais da indústria no âmbito da iniciativa 'Movimentação Empresarial pela Inovação' (MEI), com o objetivo de estimular a competitividade brasileira a partir do incentivo à inovação. Por meio da interlocução entre a iniciativa privada, academia e o setor público, o grupo trabalha para ampliar a efetividade das políticas públicas de apoio à inovação.

$\mathrm{Na}$ etapa de revisão bibliográfica, identificaram-se diversos estudos empíricos sobre inovação na indústria de transformação no Brasil (Gonçalves e Simões, 2005; Podcameni, 2007; Mendes et al., 2012; Cruz et al., 2015, Cássia e Zilber, 2016, dentre outros). Não obstante os resultados alcançados por esses estudos, questões de pesquisa relacionadas à cooperação interorganizacional em projetos de inovação das empresas de manufatura no país continuam em aberto, como as que seguem:

- A taxa de inovação apresenta variação dentre os diversos setores da indústria de transformação?

- Condições ambientais - como intensidade tecnológica e força do regime de apropriabilidade do setor - podem gerar graus distintos de oportunidades tecnológicas e de cooperação interorganizacional em projetos de inovação?

- Como a cooperação interorganizacional em projetos de inovação pode contribuir para a apropriação de valor das inovações geradas pelas empresas da indústria de transformação?

- A intensidade tecnológica e a força do regime de apropriabilidade dos 
setores em que as empresas atuam influenciam a escolha dos parceiros em arranjos cooperativos para inovação?

Essas questões motivaram a investigação do papel da cooperação interorganizacional para a efetiva apropriação de valor pelas empresas inovadoras da indústria de transformação no Brasil, tendo como fonte de dados a Pesquisa Nacional de Inovação 2014 (Pintec 2014).

Para tal, as atividades econômicas das empresas inovadoras da indústria de transformação, que responderam à Pintec 2014, foram classificadas segundo a taxonomia de intensidade tecnológica, proposta pela Organização para a Cooperação e Desenvolvimento Econômico (OCDE) em 1997 e revisada por esta instituição em 2011. A OCDE definiu um indicador de intensidade tecnológica (gasto em $\mathrm{P} \& \mathrm{D} /$ valor adicionado ou gasto em $\mathrm{P} \& \mathrm{D} /$ produção) para classificar os setores da indústria de transformação, segundo uma escala compreendendo quatro níveis, a saber: (i) alta; (ii) média-alta; (iii) média-baixa; e (iv) baixa intensidade tecnológica.

A utilização dos microdados da Pintec 2014 para correlacionar os esforços de cooperação interorganizacional com a materialização de ganhos com inovações geradas pelas empresas da indústria de transformação no Brasil vem preencher a lacuna identificada durante a revisão bibliográfica desta pesquisa, uma vez que estudos anteriores baseados em dados da Pintec não consideraram a força do regime de apropriabilidade e o nível de intensidade tecnológica setorial (OCDE, 2011) como fatores que influenciam a escolha de parceiros para o sucesso de arranjos de cooperação interorganizacional em projetos de inovação.

$\mathrm{Na}$ esfera governamental, os resultados gerados (por intensidade tecnológica setorial) serão relevantes para a formulação de políticas públicas de inovação mais consistentes e bem estruturadas para os setores da indústria de transformação no Brasil, conforme preconizado pela iniciativa 'Movimentação Empresarial pela Inovação' (MEI) da CNI.

Em particular, nos contextos institucionais do Instituto Brasileiro de Geografia e Estatística (IBGE) e do Programa Pós-MQI da PUC-Rio, destaca-se que resultados parciais da presente pesquisa foram objeto de um trabalho apresentado na 28th International Conference of the International Association for Management of Technology (IAMOT 2019), realizada em Mumbai, Índia, em abril 
de 2019. Na ocasião, o trabalho ficou classificado entre os seis melhores na categoria "Academia - Student" (Carvalho et al., 2019).

A presente dissertação insere-se na linha de pesquisa "Gestão Estratégica da Inovação e Sustentabilidade" do Programa Pós-MQI da Pontifícia Universidade Católica do Rio de Janeiro (PUC-Rio).

\section{1.}

Definição do problema de pesquisa

Considerando-se que:

- no Brasil, desde 1986, houve uma significativa perda de participação da indústria de transformação no PIB do país, configurando-se um processo de desindustrialização;

- um dos impulsionadores-chave para a retomada do crescimento da indústria de transformação brasileira e posicionamento competitivo superior no mercado global é a inovação;

- a cooperação interorganizacional em projetos de inovação pode ser considerada um dos meios de acesso das empresas inovadoras a ativos complementares estratégicos, na perspectiva de materialização do potencial de apropriação de valor pela criação de suas inovações;

- estudos empíricos sobre cooperação interorganizacional para inovação poderão subsidiar a formulação de políticas públicas de inovação mais consistentes e bem estruturadas para os setores da indústria de transformação no Brasil, conforme preconizado pela iniciativa 'Movimentação Empresarial pela Inovação' (MEI) da CNI;

definiu-se a seguinte questão principal a ser respondida ao longo da pesquisa:

"Quais as contribuições de diferentes tipos de parceiros em arranjos de cooperação interorganizacional para a efetiva apropriação de valor de empresas inovadoras da indústria de transformação no Brasil, considerando-se condições ambientais distintas e as características internas dessas empresas?".

\section{2 .}

\section{Objetivos: geral e específicos}

O objetivo geral da dissertação é analisar e comparar as contribuições de diferentes tipos de parceiros em arranjos de cooperação interorganizacional para a apropriação de valor pelas empresas inovadoras da indústria de transformação no Brasil, considerando-se condições ambientais distintas e as características internas dessas empresas. 
Para alcançar o objetivo geral, estabeleceram-se os seguintes objetivos específicos:

- Identificar as contribuições das classificações tecnológicas, referenciais teóricos e normativos sobre mensuração de resultados de PD\&I para fundamentar a análise da contribuição da cooperação interorganizacional para a apropriação de valor pelas empresas inovadoras da indústria de transformação no Brasil;

- Classificar as atividades econômicas das empresas respondentes da Pintec 2014, segundo os quatro níveis de intensidade tecnológica propostos pela OCDE (2011), com suporte da Classificação Nacional das Atividades Econômicas (CNAE 2.0 - Seção C);

- Calcular a força do regime de apropriabilidade dos setores em que as empresas atuam, com base em indicadores da Pintec referentes ao uso de métodos formais de proteção intelectual (patentes e marcas) e métodos não formais (complexidade do desenho, segredo industrial, tempo de liderança frente aos competidores e outros métodos);

- Elaborar e submeter ao IBGE projeto para acesso aos microdados não desidentificados da Pintec 2014;

- Desenvolver modelos de regressão logística para investigar a influência da cooperação interorganizacional sobre a apropriação de valor pelas empresas inovadoras, tendo como variável dependente o grau de importância atribuída por essas empresas aos impactos das inovações de produto e processo (mercado; produção; meio ambiente; saúde e segurança; e atendimento à regulamentos e normas).

- Realizar os testes de especificação dos modelos de regressão desenvolvidos (teste da razão de verossimilhança; teste de Wald; e teste de Hosmer-Lemeshow) e analisar e comparar os resultados das regressões.

\section{3.}

\section{Metodologia}

Segundo a taxonomia proposta por Vergara (2005), a pesquisa pode ser considerada descritiva e aplicada (quanto aos fins).

Quanto aos meios de investigação, a metodologia compreende:

- Pesquisa bibliográfica e documental sobre os temas centrais da pesquisa, como indicado na fase exploratória e descritiva da figura 1.1;

- Pesquisa documental referente à Classificação CNAE e ao Manual da Pintec 2014, ambas publicações do IBGE;

- Análise de conteúdo para classificar as atividades econômicas das empresas respondentes da Pintec 2014, segundo a classificação da OCDE (2011) e calcular a força do regime de apropriabilidade dos setores em que 
atuam;

- Elaboração e submissão ao IBGE do projeto para acesso aos microdados não desidentificados da Pintec 2014;

- Desenvolvimento de modelos de regressão logística para investigar a influência da cooperação interorganizacional sobre a apropriação de valor das inovações geradas pelas empresas, considerando-se fatores ambientais distintos e suas características internas;

- Realização de testes de especificação e discussão dos resultados dos modelos.

A figura 1.1, a seguir, apresenta o desenho da pesquisa, destacando seus componentes e métodos, de acordo com três fases principais: (i) exploratória e descritiva; (ii) pesquisa aplicada; e (iii) conclusivo-propositiva.

\subsection{1.}

\section{Fase exploratória e descritiva}

Esta fase foi iniciada com pesquisa bibliográfica e documental, com o objetivo de levantar trabalhos conceituais e documentos de referência para delimitação do tema central da pesquisa - "Cooperação interorganizacional e apropriação de valor das inovações geradas pelas empresas da indústria de transformação brasileira". Em seguida, aprofundou-se a revisão bibliográfica, buscando-se analisar comparativamente os escopos e métodos adotados nos estudos empíricos nacionais e de outros países sobre este tema, na perspectiva de identificar lacunas a serem preenchidas por esta pesquisa.

Nesta fase exploratória e descritiva, confirmou-se a inexistência de estudos científicos que analisassem a contribuição da cooperação interorganizacional para a apropriação de valor das inovações geradas pelas empresas da indústria de transformação, à luz da classificação de intensidade tecnológica setorial, proposta pela OCDE (2011), e da força do regime de apropriabilidade dos setores em que atuam.

A pesquisa documental abordou referenciais de inovação, como o Manual de Oslo (OCDE, 2005), bem como a Classificação CNAE e o Manual da Pintec 2014 (IBGE, 2012). Incluiu ainda a análise de conteúdo para classificar as atividades econômicas (CNAE) das empresas respondentes da Pintec 2014, segundo os quatro níveis de intensidade tecnológica setorial, conforme a classificação da OCDE. 

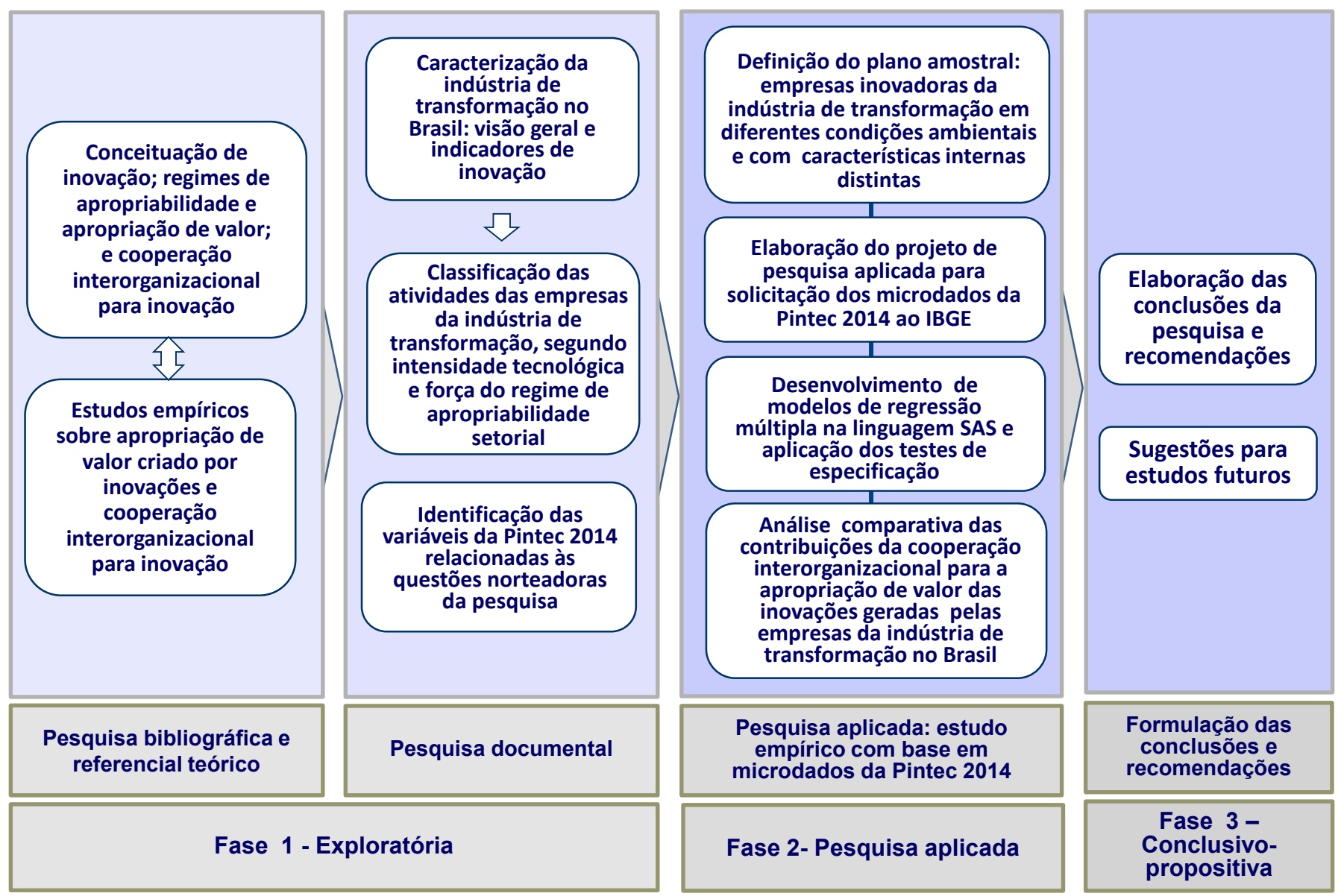

Figura 1.1 - Desenho da pesquisa, seus componentes e métodos

Fonte: Elaboração própria. 
Para a definição dos construtos e variáveis da grade de análise, partiu-se da estrutura lógica do questionário da Pintec 2014, selecionando-se as variáveis de controle, explanatórias e dependentes, tendo em vista o objetivo geral da pesquisa.

As variáveis de controle são: (i) tamanho das empresas da indústria de transformação, expresso pelas faixas de pessoal ocupado; (ii) empresas inovadoras de produto e/ou processo; e/ou com projetos incompletos ou abandonados; e (iii) cooperação interorganizacional.

As cinco variáveis dependentes referem-se à apropriação de valor das inovações geradas pelas empresas da indústria de transformação, expressa pelos impactos dessas inovações, classificados em cinco dimensões, a seguir:

- Impactos no mercado: englobando melhoria da qualidade dos produtos; ampliação da gama de produtos ofertados; manutenção da participação da empresa no mercado; e ampliação da participação da empresa no mercado;

- Impactos na produção: compreendendo aumento da capacidade produtiva; aumento da flexibilidade da produção; redução dos custos de produção; redução dos custos do trabalho;

- Impactos ambientais: abordando redução do consumo de matérias-primas; redução do consumo de energia; redução do consumo de água; redução do impacto sobre o meio ambiente;

- Impactos sociais: expressos pelo controle dos aspectos ligados à saúde e segurança;

- Impactos regulatórios: expressos pelo enquadramento em regulamentos e normas relativas ao mercado interno e externo.

$\mathrm{Na}$ sequência, listam-se as oito variáveis explanatórias referentes à importância atribuída aos parceiros em arranjos de cooperação interorganizacional ${ }^{2}$ para compor os modelos de regressão logística teóricos:

- Importância de clientes e consumidores como parceiros em arranjos cooperativos;

- Importância de fornecedores como parceiros em arranjos cooperativos;

- Importância de concorrentes como parceiros em arranjos cooperativos;

- Importância de outra empresa do grupo como parceira em arranjos cooperativos;

- Importância de empresas de consultoria como parceiras em arranjos cooperativos;

\footnotetext{
${ }^{2}$ Adota-se a definição do Manual da Pintec 2014 (IBGE, 2012) sobre cooperação interorganizacional para inovação, como sendo: "participação ativa em projetos conjuntos de P\&D e outros projetos de inovação com outra organização (empresa ou instituição). Isto não implica, necessariamente, que as partes envolvidas obtêm benefícios comerciais imediatos. A simples contratação de serviços de outra organização, sem a sua colaboração ativa, não é considerada cooperação. Os parceiros compartilham recursos e riscos no desenvolvimento do projeto de inovação.
} 
- Importância de universidades ou institutos de pesquisa como parceiros em arranjos cooperativos;

- Importância de centros de capacitação profissional e assistência técnica como parceiros em arranjos de cooperação interorganizacional;

- Importância de instituições de ensaios e certificações como parceiros em arranjos cooperativos.

Com o objetivo de investigar as contribuições de diferentes tipos de parceiros em arranjos cooperativos para inovação, as empresas da amostra foram divididas em quatro grupos mutuamente exclusivos. Para tal categorização, este estudo adotou a classificação da intensidade tecnológica nas indústrias de transformação concebida pela OCDE (2011), segundo uma escala de quatro níveis: (i) alta; (ii) média/alta; (iii) média/baixa; e (iv) baixa.

Para fins da modelagem pretendida, as empresas da amostra foram reclassificadas em dois grupos: (i) grupo AT (incluindo as empresas de alta e média/alta intensidade tecnológica); e (ii) grupo BT (incluindo as empresas de baixa e média/baixa intensidade tecnológica).

Para posterior categorização das empresas de um determinado grupo de intensidade tecnológica (AT ou BT), calculou-se a força do regime no nível dos setores (CNAE 2.0, dois dígitos), pela média da ocorrência da utilização de um ou mais mecanismos de proteção (formais ou não formais) pelas empresas de cada setor, conforme dados das tabelas 1.1.2 e 1.1.5 da Pintec 2008 (respostas binárias) ${ }^{3}$. Quando o valor médio do setor esteve acima do valor mediano de todos os setores do grupo (AT ou BT), ele foi classificado como tendo um regime de apropriabilidade forte; caso contrário, o setor foi classificado como tendo um regime de apropriabilidade fraco.

Como resultado, as empresas foram reclassificadas em quatro agrupamentos, como representado no quadro 1.1. Neste quadro, mostra-se o enquadramento conceitual preliminar a ser adotado no estudo empírico, visando investigar as contribuições de diferentes tipos de parceiros em arranjos cooperativos para inovação, realizados por empresas inovadoras da indústria de transformação no Brasil no período 2012-2014. Ao final do capítulo 2, com base na revisão da

\footnotetext{
${ }^{3}$ Desde a edição da Pintec 2011, as questões sobre mecanismos de proteção intelectual referem-se somente aos métodos informais de apropriação econômica dos resultados de PD\&I (complexidade do projeto, segredo industrial, tempo de liderança sobre os competidores e outros mecanismos). Optou-se intencionalmente pelo emprego dos dados da Pintec 2008, para que o uso de patentes e marcas (métodos formais de propriedade intelectual) pudesse ser incluído na análise da força do regime de apropriabilidade das empresas foco deste estudo.
} 
literatura sobre cooperação interorganizacional e apropriação de valor pela criação de inovações, apresenta-se o modelo conceitual a ser validado na fase da pesquisa aplicada.

Quadro 1.1 - Enquadramento inicial da pesquisa

\begin{tabular}{|c|c|c|c|}
\hline & \multicolumn{2}{|c|}{ Nível de intensidade tecnológica setorial } \\
\hline & & Alta (AT) & Baixa (BT) \\
\hline \multirow{6}{*}{ 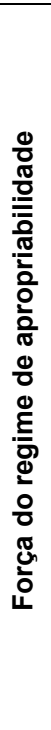 } & \multirow{3}{*}{ 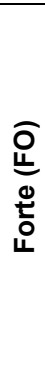 } & $\begin{array}{l}\text { Cooperação interorganizacional e } \\
\text { apropriação de valor das inovações }\end{array}$ & $\begin{array}{l}\text { Cooperação interorganizacional e } \\
\text { apropriação de valor das inovações }\end{array}$ \\
\hline & & $\begin{array}{l}\text { Principais parceiros em projetos de } \\
\text { inovação de empresas inovadoras do } \\
\text { agrupamento AT/FO, classificadas por faixa } \\
\text { de pessoal ocupado }\end{array}$ & $\begin{array}{l}\text { Principais parceiros em projetos de inovação de } \\
\text { empresas inovadoras do agrupamento BT/FO, } \\
\text { classificadas por faixa de pessoal ocupado }\end{array}$ \\
\hline & & $\begin{array}{l}\text { Impactos das inovações criadas em } \\
\text { cooperação, classificados em } \\
\text { mercadológicos; produção; ambientais; } \\
\text { sociais; regulatórios. }\end{array}$ & $\begin{array}{l}\text { Impactos das inovações criadas em } \\
\text { cooperação, classificados em mercadológicos; } \\
\text { produção; ambientais; sociais; regulatórios. }\end{array}$ \\
\hline & \multirow{3}{*}{ 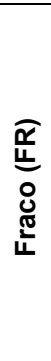 } & $\begin{array}{l}\text { Cooperação interorganizacional e } \\
\text { apropriação de valor das inovações }\end{array}$ & $\begin{array}{l}\text { Cooperação interorganizacional e } \\
\text { apropriação de valor das inovações }\end{array}$ \\
\hline & & $\begin{array}{l}\text { Principais parceiros em projetos de } \\
\text { inovação de empresas inovadoras do } \\
\text { agrupamento AT/FR, classificadas por faixa } \\
\text { de pessoal ocupado }\end{array}$ & $\begin{array}{l}\text { Principais parceiros em projetos de inovação de } \\
\text { empresas inovadoras do agrupamento BT/FR, } \\
\text { classificadas por faixa de pessoal ocupado }\end{array}$ \\
\hline & & $\begin{array}{l}\text { Impactos das inovações criadas em } \\
\text { cooperação, classificados em } \\
\text { mercadológicos; produção; ambientais; } \\
\text { sociais; regulatórios. }\end{array}$ & $\begin{array}{l}\text { Impactos das inovações criadas em } \\
\text { cooperação, classificados em mercadológicos; } \\
\text { produção; ambientais; sociais; regulatórios. }\end{array}$ \\
\hline
\end{tabular}

Fonte: Elaboração própria.

Apresenta-se na figura 1.2, a seguir, uma visão geral e esquemática dos resultados desta primeira fase, no formato de um mapa conceitual da pesquisa.

\subsection{2.}

\section{Fase de pesquisa aplicada}

$\mathrm{Na}$ fase de pesquisa aplicada, foram realizadas as seguintes etapas: (i) elaboração e submissão ao IBGE do projeto para acesso aos microdados não desidentificados da Pintec 2014; (ii) desenvolvimento de modelos de regressão logística, com uso do pacote estatístico Statistical Analysis Software (SAS); (iii) realização de testes de especificação dos modelos; e (iv) apresentação e discussão dos resultados dos modelos ajustados. 


\begin{tabular}{|c|}
\hline 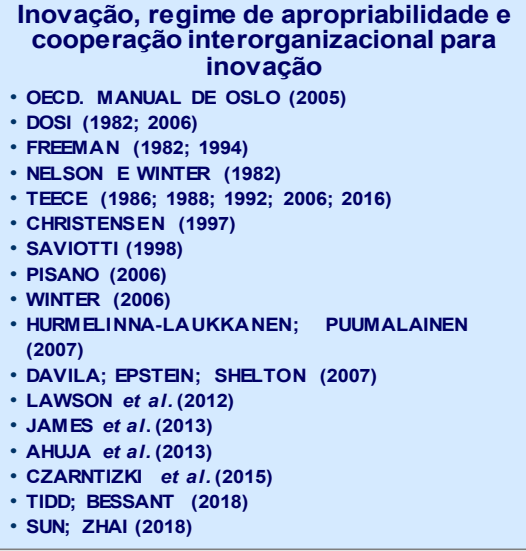 \\
\hline
\end{tabular}

Enquat

Estudos empíricos sobre cooperação interorganizacional e apropriação de

- BAYONA et al. (2001)

- VAN DIJK (2000)
TETHER (2002)

SAE et al. (2002)

BONTE; KELBACH (2005)

SILVA et al. (2005)

- LHUILLERY; PFISTER (2009)

HURMELINNA; PUUMALAINEN $(2005 ; 2007)$

- hURMELINNA et al. (2007)

N et al. (2008)

(2009)

RITALA; HURMELINNA-LAUKKANEN (2013)

- PIRES (2013)

- OLANDER et al. (2014)

SMIT (2014)

- MOURA (2016) TERLINCKA (2015)

HENTLONEN: HURM

GINNA-LAUKKANEN (2016)

- SEO et al. (2017)

- PERERA (2017)

Enquadramento

o estudo

empírico

\begin{tabular}{|c|}
\hline $\begin{array}{c}\text { Caracterização da } \\
\text { indústria de } \\
\text { transformação no Brasil: } \\
\text { visão geral e indicadores } \\
\text { de inovação }\end{array}$ \\
\hline $\begin{array}{l}\text { - FESP (2019) } \\
\text { IEDI (2018) }\end{array}$ \\
\hline $\begin{array}{l}\text { - Indicadores de inovação } \\
\text { (IBGE, 2016) }\end{array}$ \\
\hline
\end{tabular}

\section{Pintec 2014 como fonte de}

- IBGE $(2012 ; 2016)$

- Classificação CNAE das
atividades da indústria de

transformação

(OCDE, 2011)

Identificação das variáveis da

(a)

pesquisa (IBGE, 2016)

Figura 1.2 - Mapa conceitual da pesquisa

Fonte: Elaboração própria. 


\subsection{3.}

\section{Fase conclusivo-propositiva}

$\mathrm{Na}$ terceira fase, elaboraram-se a conclusão geral e as específicas em relação aos objetivos da presente pesquisa. Formulou-se ainda um conjunto de sugestões de temas de estudos acadêmicos futuros, como desdobramentos desta pesquisa.

\section{4.}

\section{Estrutura da dissertação}

A dissertação encontra-se estruturada em cinco capítulos, incluindo esta introdução.

No capítulo 2, apresentam-se os conceitos básicos referentes à inovação, destacando-se os mecanismos de apropriabilidade a serem adotados pelas empresas visando apropriação de valor pela criação de suas inovações, a arquitetura setorial e uso de ativos complementares. Essa conceituação inicial visa fundamentar a discussão sobre a contribuição da cooperação interorganizacional para a apropriação de valor das inovações criadas pelas empresas em geral e, em particular, pelas empresas da indústria de transformação no Brasil. Ao final, propõe-se o modelo conceitual como base para o desenvolvimento do estudo empírico.

No capítulo 3, apresenta-se inicialmente um panorama geral da indústria brasileira de transformação no Brasil, como pano de fundo para a discussão das características da inovação nessa indústria. A partir dos indicadores da Pintec 2014, busca-se caracterizar as empresas que geraram inovações no período 20122014 (inovações de produto e/ou processo ou com projetos de inovação).

No capítulo 4, apresentam-se e discutem-se os resultados do estudo empírico sobre as contribuições de diferentes tipos de parceiros em arranjos de cooperação interorganizacional para a apropriação de valor das inovações geradas pelas empresas da indústria de transformação no Brasil. Para tal, utilizaram-se microdados da Pintec 2014 de 1520 empresas da indústria brasileira de transformação que responderem a Pesquisa e que inovaram em aranjos cooperativos com outras organizações no período 2012-2014.

Finalmente, no capítulo 5, formulam-se as conclusões da pesquisa e endereçam-se propostas para estudos futuros, como desdobramentos naturais e aprofundamento de aspectos relevantes que emergiram desta dissertação. 


\section{2 \\ Inovação, cooperação interorganizacional e apropriação de valor pela criação de inovações}

Apresentam-se os conceitos básicos referentes à inovação, destacando-se os mecanismos de apropriabilidade (formais e não-formais) a serem adotados pelas empresas visando apropriação de valor pela criação de suas inovações, a arquitetura setorial e uso de ativos complementares. Essa conceituação inicial visa fundamentar a discussão sobre a contribuição da cooperação interorganizacional para a apropriação de valor das inovações criadas pelas empresas em geral e, em particular, pelas empresas da indústria de transformação no Brasil (escopo do estudo empírico).

\section{1.}

Inovação: conceitos, definições e tipologias

Atualmente, o mercado global caracteriza-se por uma acirrada concorrência, constantes mudanças nas preferências dos clientes e do ambiente de negócios, bem como por avanços consideráveis das tecnologias que intensificam a necessidade de inovação das empresas (Goffin e Mitchell, 2010).

A inovação tem sido discutida há décadas, por várias disciplinas, uma vez que sua importância foi notada pela primeira vez por Jeremy Bentham e depois enfatizada por Joseph Schumpeter, despertando interesses e atenção de pesquisadores e profissionais.

O conceito de inovação é bastante abrangente e complexo (Adams, Bessant, e Phelps, 2006). Existem diversos autores, estudiosos no tema, que se propuseram conceituar inovação com o intuito de classificar, dimensionar e evidenciar sua importância num contexto de determinar a competitividade das indústrias e das empresas em seus respectivos ramos de negócio (Porter, 1989; 1998). Dentre eles, destacam-se os trabalhos de Schumpeter (1961); Nelson e Winter (1982); Dosi (1982; 2006); Pavitt (1984); Freeman (1982; 1994); Freeman e Soete (1997); e Freeman e Perez (1988). 
Alguns pesquisadores conseguem desenvolver uma definição multidisciplinar de inovação, integrando sobreposições entre as definições de inovação específicas das disciplinas, incluindo economia, inovação e empreendedorismo, gestão de negócios e tecnologia, ciência e engenharia (Damanpour e Schneider, 2006). Por exemplo, Baregheh et al. (2009, p. 1334) propõem que "a inovação é um processo em múltiplos estágios em que as organizações transformam ideias em produtos, serviços ou processos novos/aprimorados, a fim de avançar, competir e diferenciar-se com sucesso em seu mercado". No entanto, a generalidade da definição sacrifica a especificidade, diminuindo a utilidade (praticidade e aplicabilidade) da definição interdisciplinar.

Tem sido amplamente reconhecido que a inovação significa a renovação e desempenha um papel crítico na criação de valor e na melhoria das competências de uma empresa (Danneels, 2002; Francis e Bessant, 2005; Baregheh et al., 2009).

Schumpeter (1961) foi o primeiro a afirmar que o desenvolvimento econômico é impulsionado pela inovação e que as inovações podem ocorrer de cinco formas diferentes:

(i) introdução de um novo produto ou nova qualidade do produto;

(ii) introdução de um novo método de produção;

(iii) abertura de um novo mercado;

(iv) descoberta de uma nova fonte de fornecimento de matéria-prima;

(v) mudanças na organização de qualquer tipo de indústria (criando uma posição monopolista ou a ruptura de um monopólio.

É de suma importância que se faça uma distinção entre os conceitos de invenção e inovação. Uma invenção é uma ideia, um esboço ou um modelo para um produto, um processo ou um sistema novo ou melhorado. A invenção, mesmo que patenteada, na maioria das vezes não se converte em inovação (Freeman e Soete, 1997), sendo apenas um ato de criação de novo conhecimento.

Já uma inovação permite a aplicação econômica e social da invenção, traduzindo-se pela incorporação de novo conhecimento em novos processos ou produtos. Desse modo, a inovação converte em realidade aquilo que na invenção se mantinha em estado de latência. Assim, o bem (produto ou serviço) passa de vendável a vendido (Dosi, 1982; 2006), pois uma inovação é concretizada apenas 
com a primeira transação comercial, isto é, com a chegada ao mercado do novo produto ou do novo processo de produção (Freeman e Soete, 1997).

Schumpeter (1961) propõe uma definição de inovação mais simples e abrangente, considerando-a como uma aplicação concreta da invenção, onde esta é a descoberta de algo novo na esfera da vida econômica. A inovação é um elemento importante na formação dos ciclos econômicos: o "boom" tem início a partir de uma inovação que pode levar a economia ao desequilíbrio (capaz de romper o fluxo circular) e termina quando o processo de difusão chega ao esgotamento originando uma crise que se transforma numa depressão. Em seu livro intitulado "Capitalismo, Socialismo e Democracia”, de 1961, descreve o processo de inovação, o chamado "Creative Destruction". A expressão que pode ser traduzida como "Destruição Criativa", é uma metáfora bastante difundida e que sintetiza todo o potencial de evolução do capitalismo na imagem da destruição do velho pela criação do novo, trazendo à tona seu caráter endógeno, a necessidade de sua visão no tempo, o papel central das inovações, da criação de crédito e o papel do empreendedor e das grandes empresas.

De acordo com Freeman (1982; 1994), inovação é o processo que inclui as atividades técnicas, concepção, desenvolvimento, gestão e que resulta na comercialização de novos (ou melhorados) produtos, ou na primeira utilização de novos (ou melhorados) processos. Inovação pode ser também definida como fazer mais com menos recursos, por permitir ganhos de eficiência em processos, quer produtivos, administrativos ou financeiros.

O conceito de inovação inclui não só a primeira utilização de determinada tecnologia em uma dada unidade do sistema econômico, mas também a sua difusão. Ou seja, uma empresa que utiliza, pela primeira vez, algum processo produtivo ou que fabrica, pioneiramente, um determinado produto é considerada uma empresa inovadora, independentemente do processo ou produto ser ou não novo para os seus concorrentes e para os utilizadores.

Também Ernst, Ganiatsos e Mytelka (1998) e Mytelka e Farinalli (2000) encaram a inovação com esse significado. Esses autores afirmam que a inovação ultrapassa as atividades de $\mathrm{P} \& \mathrm{D}$, para incluir melhorias contínuas na concepção e qualidade dos produtos, mudanças na organização e nas rotinas de gestão, criatividade nas estratégias de marketing e, ainda, modificações nos processos de 
produção visando redução dos custos, melhoria da eficiência e crescimento sustentado.

Dentre as dimensões, o nível de avaliação (por exemplo, indivíduo, grupo, empresa, setor da indústria, grupo de consumidores, região e país) é a dimensão mais discutida, seguida por tipo de inovação (produto versus processo, incremental versus radical; organizacional versus tecnológica; modelo de negócio versus conceito de negócio) (Gopalakrishnan e Damanpour, 1994; e Crossan e Apaydin, 2010).

Entre os níveis de análise, o nível empresarial é o mais frequentemente analisado na literatura, enquanto o nível do setor da indústria é muito menos representado (Crossan e Apaydin, 2010).

Autores como Schumpeter (1961), Freeman e Perez (1988) e Tushman e Anderson (1986) classificam as inovações em incrementais ou radicais. Essa classificação refere-se particularmente ao grau de novidades decorrente da efetivação da inovação na organização.

- Inovações incrementais: correspondem às alterações marginais nos produtos ou processos, acontecendo em qualquer setor e influenciando positivamente a produtividade. Sua origem advém tanto de melhorias quanto de invenções aventadas pelo pessoal da produção como também dos clientes desses produtos ou serviços.

- Inovações radicais: são transformações fundamentais que ocorrem envolvendo a mudança no paradigma tecnológico vigente, quando do desenvolvimento e introdução de um novo produto, processo ou forma de organização da produção inteiramente nova.

Teece (1986) propôs uma evolução para esta classificação, evidenciando a forma pela qual as empresas se beneficiam de inovações radicais, por meio da apropriabilidade e dos ativos complementares. A apropriabilidade significa a proteção que a tecnologia pode obter, impedindo o aparecimento de imitações e oportunizando ao inovador o retorno econômico. A complementaridade refere-se a todas as outras competências que a empresa deve ter, além daquela específica que dá suporte à tecnologia.

Quando se leva em consideração a dimensão tecnologia, não existe dificuldade em identificar tanto uma inovação incremental, quanto uma inovação radical. Em contrapartida, ao se analisar conjuntamente os aspectos tecnológicos e 
as características do modelo de negócio no nível da empresa, aparecem correspondências que possibilitam a identificação de três grupos diferentes de inovações: as radicais, as semirradicais e as incrementais.

Segundo Davila, Epstein e Shelton (2007), nem todas as inovações são criadas da mesma forma, uma vez que não explicitam os mesmos riscos nem oferecem recompensas semelhantes. Para os autores, os tipos de inovação no nível da empresa são:

- Incrementais: quando são estabelecidas melhorias moderadas nos produtos e processos da organização.

- Semirradicais: envolvem mudanças substanciais no modelo de negócios ou na tecnologia de uma organização, mas não em ambas.

- Radicais: conjunto de novos produtos e/ou serviços fornecidos de modo inteiramente novo.

Outra forma de classificação é proposta por Francis e Bessant (2005) que classificam as inovações segundo quatro categorias, como segue:

- Inovação de produto: baseia-se nas modificações ocorridas nos bens e serviços ofertados por uma organização;

- Inovação de processo: fundamenta-se nas transformações advindas dos processos para fabricação e oferta de bens e serviços;

- Inovação de posicionamento: consiste em definir ou redefinir o posicionamento de um produto em outros segmentos de mercado;

- Inovação de paradigma: constitui-se em definir ou redefinir os paradigmas da organização, podendo ser internos (valores organizacionais e política de tomada de decisão) e externos (o modelo de negócios, a forma conceitual que a empresa utiliza para prosperar no mercado).

Christensen (1997) caracterizou ainda as inovações chamadas disruptivas (disruptive innovations), que geralmente costumam ser confundidas com as inovações radicais.

Inovações disruptivas são consideradas simples ao se comparar com as tecnologias e processos que as antecedem e sua estrutura usualmente se baseia em uma associação de elementos pouco valorizados pelas organizações já constituídas. Caracterizam-se por oferecer menos que os consumidores de mercados consolidados estão habituados a receber e, por isso, inicialmente fazem parte de mercados emergentes que não utilizam os produtos/serviços disponíveis, seja por falta de recursos ou excesso de sofisticação. Apesar das ideias de ruptura 
originarem-se a partir de organizações estabelecidas, muitas vezes elas são ignoradas em razão do pouco grau de incentivo financeiro oferecido aos seus produtos de linha.

Para fins da presente pesquisa, adotam-se as definições do Manual de Oslo (OCDE, 2005), publicação internacional de referência que estabelece diretrizes para a coleta e uso de dados sobre as atividades de inovação na indústria e é adotado como guia nas pesquisas nacionais de inovação, inclusive a Pintec/IBGE (fonte de dados para o estudo empírico apresentado no capítulo 4).

Segundo o Manual de Oslo, distinguem-se quatro tipos de inovação, a saber:

- Inovação de produto: compreende uma mudança significativa em bens e serviços, introduzindo novos bens ou serviços, ou aperfeiçoando os produtos já existentes;

- Inovação de processo: compreende mudanças significativas nos métodos de produção e/ou distribuição de produtos;

- Inovação organizacional: refere-se à implementação de novos métodos organizacionais que podem conter mudanças em práticas da organização, transformações no ambiente interno ou nas relações externas da empresa;

- Inovação de marketing: envolve a implementação de novos métodos de marketing, podendo implicar em mudanças na aparência e embalagem do produto, nos métodos de promoção e apresentação do produto e em métodos para a definição de preços de bens e serviços.

Cabe destacar ainda uma segunda classificação das inovações estabelecida no Manual de Oslo (2005, p. 24; 69), segundo o seu grau de abrangência e originalidade:

- Nova para a empresa: quando a novidade implementada está limitada ao âmbito da empresa, mesmo que as mudanças já existam em outras empresas.

- Nova para o mercado: quando a empresa é a primeira a introduzir a inovação em seu mercado. O escopo geográfico do que é novo para o mercado está sujeito, pois, à própria visão da empresa sobre seu mercado de operação e pode incluir empresas domésticas ou internacionais.

- Nova para o mundo: quando a empresa é a primeira a introduzir a inovação em todos os mercados e indústrias, domésticas ou internacionais. Assim, uma inovação nova para o mundo implica em um grau de novidade qualitativamente maior do que uma inovação nova somente para o mercado. 


\section{2. \\ Cooperação interorganizacional para inovação}

Cooperação interorganizacional se dá quando as entidades envolvidas optam por agir em conjunto em torno de um propósito maior, compartilhando conhecimento, ativos e competências. As entidades envolvidas em arranjos cooperativos compartilham riscos e ganhos e esses podem ser de diferentes tipos: (i) financeiros por escala; (ii) manutenção de flexibilidade; (iii) soluções com benefícios coletivos; (iv) acesso a novos mercados ou manutenção de posicionamento competitivo nos mercados em que atuam; (v) atendimento a regulamentos e requisitos de normas aplicáveis; e (vi) ganhos de competitividade.

Para fins da presente pesquisa, focaliza-se o tema cooperação interorganizacional na perspectiva de formação de arranjos cooperativos para desenvolvimento conjunto de projetos de PD\&I. Adota-se a definição apresentada no questionário da Pintec 2014 (IBGE, 2012, p.9), como segue:

“Cooperação para inovação significa a participação ativa em projetos conjuntos de P\&D e outros projetos de inovação com outra organização (empresa ou instituição). Isto não implica, necessariamente, que as partes envolvidas obtêm benefícios comerciais imediatos. A simples contratação de serviços de outra organização, sem a sua colaboração ativa, não é considerada cooperação".

A cooperação interorganizacional entre empresas inovadoras e outras organizações tem sido foco de diversos estudos empíricos identificados na fase de revisão bibliográfica desta pesquisa e abordados em detalhe no item 2.4 deste capítulo (Bayona et al., 2001; Sáez et al., 2002; Veugelers e Cassiman, 2005; Bönte e Keilbach, 2005; Silva et al., 2005; Arranz e Arroyabe, 2008; Lhuillery e Pfister, 2009; Hurmelinna-Laukkanen, 2011; Capaldo e Petruzzelli, 2011; Wu, 2012; Pires, 2013; Spithovena e Teirlinck, 2015; Czarnitzki et al., 2015; Henttonen; Hurmelinna-Laukkanen e Ritala, 2016; Veer; Lorenz e Blind, 2016; Moura, 2016; Pereira, 2017; e Lorenz e Veer, 2019).

Esse tema também tem sido foco de um debate mais amplo sobre Sistemas Nacionais de Inovação e Políticas Públicas de Ciência e Tecnologia (C\&T) e Industrial de diversos países e regiões. Nesse contexto, discute-se adiante neste capítulo a importância da cooperação interorganizacional em projetos de inovação como um dos meios de acesso das empresas inovadoras a ativos complementares 
estratégicos, na perspectiva de materialização do potencial de apropriação de valor pela criação de suas inovações.

\section{3. \\ Mecanismos para apropriação de valor: formais e não formais}

O conhecimento possui algumas características específicas que o diferenciam dos demais fatores de produção, entre as quais se destacam sua intangibilidade e capacidade de não possuir vínculos a determinado lugar. Conforme Polanyi (1967), o conhecimento humano é classificado em conhecimento codificado (explícito) e tácito. O primeiro permite a representação escrita e é facilmente registrado, sistematizado e comunicado, podendo ser formalmente transmitido as outras pessoas. Ao contrário, o conhecimento tácito retrata as experiências individuais dos agentes e é constituído por elementos intangíveis como instituições, crenças, emoções e habilidades, o que dificulta sua representação em linguagem formal. Ambos os conhecimentos, contudo, são unidades que se completam e a interação entre eles condiciona a dinâmica da criação do total de conhecimento.

Mesmo sendo tácito e idiossincrático, o conhecimento pode ser transferido ou reproduzido quase sem custos, em um tempo extremamente rápido e com alcance ilimitado. Isto decorre do fato de que a maior parte do conhecimento existente, especialmente no meio acadêmico, é publicamente disponível e as infrações da propriedade intelectual ainda não são consideradas com devida relevância. Por conseguinte, as características inerentes ao conhecimento fazem com que este se torne extremamente vulnerável à exploração por parte dos free riders.

Diante disso a estimulação e a manutenção de investimentos em atividades de PD\&I requerem uma ampla disposição de medidas que objetivem conservar os rendimentos originados pela transposição dos conhecimentos ao sistema econômico, tendo em vista o montante significativo de recursos necessários para a sua concepção. Tais medidas são representadas por mecanismos de proteção, que podem ser classificados como informais e formais. No que se refere aos primeiros, os mais destacados são:

- Complexidade tecnológica, para que o entendimento seja dificultado;

- Segredo industrial, para manutenção secreta dos conhecimentos gerados;

- Tempo de liderança frente aos concorrentes (lead time), ou seja, utilização da liderança no tempo como monopólio temporário decorrente da rápida 
entrada de uma empresa no mercado.

No entanto, tais medidas mostram-se pouco eficientes para proteger as inovações baseadas em conhecimento, o que ocorre, por um lado, porque a manutenção secreta dos conhecimentos gerados somente é possível até a inserção do produto ou serviço no mercado e, por outro, devido ao curto ciclo da inovação e da velocidade na qual os competidores no mercado são capazes de realizar uma imitação, tornando a vantagem do tempo de liderança modesta.

Com relação aos mecanismos formais, estes representam direitos exclusivos, legalmente garantidos e com prazos limitados, que conferem ao seu proprietário uma série de possibilidades para impedir e punir o uso indevido do conhecimento protegido. Como exemplo, pode-se mencionar os direitos autorais (copyright), patentes, modelos de utilidade, desenhos industriais, entre outros.

A proteção formal tem como objetivo impedir, ou pelo menos restringir, três categorias de fraudes e concorrência desleal: (i) a cópia, que parece verdadeira quando analisada objetivamente, como, por exemplo, a falsificação; (ii) a imitação ilícita, que conduz a confusão quando apreciada subjetivamente pelo consumidor; e (iii) A competição desfavorável, que leva vantagem de uma semelhança que não é apreciada objetivamente, mas economicamente.

Entre os instrumentos formais, as patentes têm-se destacado em discussões recentes no tocante à proteção das atividades inovadoras no meio acadêmico. Isto se deve a uma série de características inerentes apresentadas por estas. Uma delas é que as patentes são caracterizadas pela "livre transferibilidade", constituindo-se em um mecanismo único e altamente visível de transferência de conhecimento tecnológico ao setor privado (Basberg, 1987).

O conceito da "livre transferibilidade" relaciona-se ao fato de que as patentes representam um título legal que pode estar sujeito tanto ao licenciamento como também à venda e à avaliação individual que, ao conferirem exclusividades temporárias de comercialização, permitem aos produtores recuperarem os custos do investimento em P\&D e auferirem lucros, o que torna possível sua utilização como garantia de crédito, capital próprio e participações em empresas. 


\section{4 . \\ Regime de apropriabilidade: fatores determinantes do uso e da eficácia dos mecanismos}

Para se compreender o regime de apropriabilidade disponibilizado para cada projeto de PD\&I e se estabelecer a mensuração do grau de apropriabilidade das soluções tecnológicas inovadoras desenvolvidas no âmbito das empresas, torna-se importante entender quais são os fatores que afetam a inclusão de mecanismos de apropriabilidade no regime e que podem ser utilizados sobre os resultados do projeto, estabelecendo-se parâmetros para cada um desses mecanismos, de tal sorte a quantificar o nível de proteção que garante a exclusividade no uso da tecnologia inovadora.

O termo apropriabilidade refere-se às condições em torno de um novo conhecimento que permitem a captura de seu valor. Em outras palavras, apropriabilidade é a capacidade de impossibilitar a ação de imitadores e de garantir o retorno otimizado dos investimentos em P\&D e inovação (Almeida et al., 2012).

O nível de apropriabilidade de uma tecnologia inovadora é determinado por um conjunto de mecanismos que impedem a imediata difusão/diluição da vantagem obtida pela empresa inovadora. Entre estes se destacam o tempo e o custo de imitação - quanto menores, mais baixo o grau de apropriabilidade, e vice-versa.

A existência desse regime explicaria o porquê de empresas inovadoras, por vezes, não conseguirem manter uma posição de liderança em função do pioneirismo. As instâncias mais relevantes de um regime de apropriação englobam a natureza da tecnologia e os mecanismos de proteção à propriedade intelectual. Isto é, a apropriação e a utilização de cada instrumento de proteção legal varia conforme a indústria (e dentro de uma mesma indústria), setor e país (pois ocorrem variações na aplicação da legislação de proteção à propriedade intelectual de acordo com especificidades nacionais).

Assim, a eficácia dos mecanismos de apropriação deve ser avaliada a partir de sua capacidade de afetar custos e tempo de imitação, criando ou reforçando as condições de apropriabilidade. A grande questão é se esses mecanismos são uma condição necessária e/ou suficiente para a apropriação dos resultados dos projetos inovadores, observando-se, ainda, que a eficácia admite graus - entre a total eficácia e a nula, há um contínuo de situações intermediárias. Alto nível de eficácia 
acarretaria, em tese, um efeito positivo do ponto de vista do agente inovador; porém, pode ter outros efeitos conforme a posição do agente no processo competitivo pode ser negativo, por exemplo, para organizações que adotam estratégias baseadas na imitação. O efeito de determinados mecanismos pode ainda ser negativo do ponto de vista social por implicar restrições à concorrência e à difusão da tecnologia.

Diversos autores, como Arrow (1962), Kay (1988), Teece (1988; 1992; 2006) e Dosi (2006), concordam que a apropriabilidade é uma forma de incentivo e estímulo para a incorporação das atividades de P\&D. De acordo com Leopardi (2008), essa é uma relação que pode ser confirmada em diversos estudos empíricos, entretanto, as opiniões dos autores divergem em torno do grau de proteção necessário para esse incentivo, acima do qual a proteção teria um efeito restritivo, não justificável, da disseminação do conhecimento.

Hurmelinna-Laukkanen e Puumalainen (2007) definem um regime de apropriabilidade como sendo composto de diferentes mecanismos que são utilizados pelas empresas para proteger as inovações e os possíveis retornos correspondentes. Estes mecanismos são uma combinação de capacidades tecnológicas e de marketing, conhecimento básico existente e, por exemplo, a capacidade de aprendizado. Também existem outras formas de impedir que os concorrentes imitem determinados produtos previamente pesquisados. Exemplos disso são direitos de propriedade intelectual, contratos de trabalho e lead time. Em geral, este regime deve ser capaz de proteger inovações dos imitadores.

As organizações têm uma variedade de mecanismos de proteção (e apropriabilidade) do conhecimento à sua disposição e, confiando nelas, podem tornar os ativos intelectuais mais rígidos e impedir ou retardar a imitação de seus intangíveis mais importantes (Hurmelinna-Laukkanen e Puumalainen, 2007). A exclusividade obtida, por sua vez, pode ser usada para aumentar a capacidade de gerenciar ativos intangíveis (que podem incorporar mais obviamente conhecimento técnico, relacionado ao produto ou serviço, mas também mais conhecimento relacionado a negócios), não apenas em termos de proteção, mas também em utilizá-los em empreendimentos colaborativos.

Para que o processo de PD\&I possa obter retornos dos investimentos minimizando a ação da concorrência, faz-se necessário que a empresa crie, adote e 
implemente um regime de apropriabilidade em cada projeto de inovação (Naqshbandi e Kaur, 2011; Hurmelinna e Puumalainen, 2005).

Numa tentativa de investigar quem ganha com a inovação, Teece (1986) identificou três fatores predominantes que explicam a distribuição dos lucros de uma inovação entre a empresa inovadora, imitadores e demais concorrentes, a saber: (i) regime de apropriabilidade; (ii) estágio do projeto dominante (dominant design); e (iii) acesso aos ativos complementares.

Segundo Teece (1986), o conceito de 'regime de apropriabilidade' de uma empresa se refere a "fatores ambientais, excluindo-se sua estrutura e do mercado, que governam a habilidade dessa organização obter os lucros advindos de uma inovação". Tratam-se de mecanismos que estabelecem medidas adotadas para que as inovações possam ser protegidas dos imitadores. Estão incluídas neste conceito uma dimensão da eficácia dos mecanismos legais de proteção, relacionada a patentes e segredos industriais, e uma dimensão tecnológica, relacionada à natureza da tecnologia e do conhecimento envolvido, se tácito ou codificado.

Arrow (1962) aponta que "os direitos de propriedade impostos legalmente podem fornecer apenas uma barreira parcial", sugerindo, assim, a necessidade de mecanismos complementares. Mecanismos de proteção da propriedade intelectual também chamados de mecanismos de apropriabilidade (ver, por exemplo, Cohen et al., 2000), têm sido mais frequentemente categorizados como formais ou informais. O regime de apropriabilidade normalmente é categorizado, sem uma fronteira bem definida, como "forte" ou "fraco", de acordo com a possibilidade que confere aos inovadores de se apropriar do valor gerado por sua inovação.

Teece (1986) definiu que o regime de apropriabilidade pode ser caracterizado como forte, quando os conhecimentos de PD\&I são tácitos e/ou os mecanismos de proteção intelectual são eficazes. Por outro lado, o regime pode ser considerado fraco, quando os conhecimentos são codificáveis e/ou os mecanismos de proteção são ineficazes.

A seguir, apresentam-se alguns outros conceitos básicos necessários para um bom entendimento do modelo Profiting from Innovation - PFI (Teece, 1986; 2006; 2016), o qual, é considerado um marco na literatura sobre apropriabilidade do sresultados de PD\&I e a relação entre inovação e a estratégia de negócios. 


\section{5 . \\ Decisões sobre o uso de mecanismos para apropriação de valor}

As empresas têm à sua disposição vários instrumentos, métodos e estratégias para proteger o conhecimento (intangíveis) e seus ativos tangíveis, contra possíveis imitações ilícitas promovidas por seus concorrentes a um custo mais baixo. Diante disso, as instituições devem buscar esses mecanismos de proteção, a fim de assegurar a apropriação econômica dos seus esforços de P\&D e inovação, como também criar barreiras para que os imitadores não copiem livremente suas criações, tornando seus conhecimentos menos transferíveis e seus ativos tangíveis exclusivos. Esses mecanismos são chamados na literatura de mecanismos de apropriabilidade, mecanismos de isolamento (Rumelt, 1987) ou mecanismos de proteção à propriedade intelectual (Hipp e Herstatt, 2006).

Diferentes mecanismos podem ser empregados nas várias etapas do processo de inovação. As empresas podem inicialmente confiar no segredo industrial antes da comercialização de um novo produto e, mais tarde, solicitar uma patente e/ou adotar estratégias agressivas de marketing e liderança no tempo (lead time). Por sua vez, a liderança no tempo pode ser usada para obter vantagens na manufatura (movendo-se ao longo da curva de aprendizado e ganhando economias de escala) e marketing (construindo vendas de marketing e capacidades de serviço), e para retardar a imitação por concorrentes (Harabi,1995). Portanto, mais de um mecanismo pode ser empregado ao mesmo tempo para uma dada tecnologia e inovação quando compreende componentes ou características separadamente protegíveis (Cohen et al., 2000), ou quando a legislação permite um "empilhamento" de DPI sobre a mesma invenção. Finalmente, a eficácia dos diferentes mecanismos varia ao longo do tempo; segredos industriais podem ser revelados, patentes expiram e podem ser inventadas em qualquer lugar, por outro lado, marcas registradas, por exemplo, podem aumentar drasticamente seu valor e serem renovadas indefinidamente (Hurmelinna e Puumalainen, 2005).

\subsection{1.}

\section{Segredo industrial}

O segredo industrial ou comercial consiste em manter as informações restritas aos envolvidos com os respectivos projetos, prevenindo que qualquer elemento essencial do conhecimento seja levado para fora da empresa. O segredo cobre uma 
ampla gama de informações confidenciais, desde aspectos técnicos, como fórmulas, know-how e processos de produção, até informações dos clientes/consumidores/ empregados da empresa parceira, e estratégias de vendas.

$\mathrm{O}$ segredo industrial depende de imposição, às vezes, unilateral, de obrigações pessoais, por meio de cláusulas contratuais de confidencialidade. A natureza deste contrato, que pode ser implícito ou explícito, pode dar à uma das partes - diga-se o empregador - direitos, enquanto que dá a outra parte - o empregado - restrições.

A proteção por meio do segredo industrial é, em grande parte, conseguida com a participação de gestores das empresas, mais do que pela adoção de procedimentos legais. Assim é importante que os gestores entendam o que representa o segredo industrial e o que o ambiente legal vigente sugere como seus direitos, responsabilidades e restrições.

O principal problema do segredo industrial é que na prática o mesmo só fornece efetiva proteção se a inovação não puder ser facilmente observada e replicada com a utilização de processos de engenharia reversa, como o que ocorre no caso das inovações de processos.

\subsection{2.}

\section{Complexidade tecnológica}

A complexidade tecnológica está relacionada a tornar a tecnologia ou o design complexo para manter ou proteger segredos relevantes. Em geral, um design complexo é difícil de imitar. Além disso, é difícil para os concorrentes fazer engenharia reversa dos itens de complexidade da tecnologia, o que é em si uma medida de proteção.

Assim como no caso das patentes, a complexidade tecnológica influencia a eficácia dos segredos, com inovações discretas sendo mais facilmente alvo de engenharia reversa e, portanto, de proteção mais difícil (James et al., 2013).

Pela mesma razão, segredos são mais eficazes para inovações de processos do que de produtos (Milesi et al., 2013).

Vale mencionar que, no caso da complexidade tecnológica, o aumento desta também implica em um custo maior de manutenção do segredo que pode afetar a apropriação de valor (James et al., 2013). 
A complexidade tecnológica é significativa no desenvolvimento de engenharia de produto, no qual os projetistas precisam considerar esse aspecto para criar um produto funcional e confiável. As medidas de complexidade tecnológica são importantes para apoiar a gestão de empresas de manufatura nas decisões relativas à seleção de novos produtos a serem fabricados e sua produção. Uma vez que um nível de complexidade tecnológica é definido para cada produto, é possível desenvolver estudos de viabilidade para verificar a capacidade da planta de produzilo.

A complexidade do projeto é um mecanismo de apropriação considerado indireto e informal, pois geralmente inclui parcerias entre empresas e universidades, formação de alianças estratégicas, lançamento constante de novas tecnologias, avaliação das necessidades do mercado, mudanças na estrutura organizacional, contratação e treinamento de pesquisadores, contratação e treinamento de negociadores, criação estratégica de spin-offs, criação de incubadoras tecnológicas, desenvolvimento de tecnologias combinadas, complexidade de design de produtos, estratégias de marketing, dentre outros.

\subsection{3.}

\section{Tempo de liderança frente aos concorrentes}

Alguns estudos, principalmente da indústria aeronáutica e de semicondutores, mostram que ganhar tempo até divulgar um novo conhecimento ou produto inovador e explorar as vantagens da curva de aprendizagem são os principais meios de apropriabilidade dos retornos da PD\&I. Há também, outros estudos que enfatizam a importância dos investimentos em ativos complementares, tais como, marketing e atendimento ao cliente como sendo estratégicos para se obter os retornos almejados. No entanto, com o aprofundamento de estudos na área de apropriabilidade, tem-se observado que cada vez mais a competitividade das organizações depende do resultado dos avanços tecnológicos obtidos por essas empresas (Dosi, 1982; 2006; Nelson e Winter, 1982).

Diante disso, em alguns setores industriais, principalmente os intensivos em tecnologia, tem-se observado uma forma de apropriabilidade como sendo de fundamental importância para se obter bons retornos dos investimentos em P\&D e inovação. Esse mecanismo está relacionado ao fato de que o imitador terá de reproduzir todo o processo inovativo, dedicando muito tempo, grande investimento 
e muitos recursos para obter retornos favoráveis. Está diretamente relacionado à complexidade da tecnologia e à curva de aprendizagem.

A literatura intitula esse mecanismo como "lead time" ou time-to-market, definido como o tempo necessário para que a organização transforme sua invenção em inovação, ou seja, o tempo necessário para percorrer o chamado funil de inovação até iniciar a comercialização do produto (introdução no mercado). Uma organização pode ser capaz de converter sua liderança no tempo em um conjunto de vantagens peculiar de primeiro entrante (first-mover), pelo fato de ser a única e a primeira organização a ter a ideia e saber como implementá-la (Boldrin e Levine, 2008).

Essas vantagens podem ocorrer, pelo lado da oferta, pelo alcance de economias de escala; pela exploração de curvas de aprendizado; e por vantagens relacionadas às incertezas de custos improváveis inerentes ao conhecimento e práticas de difícil imitação. Pelo lado da demanda, a organização pode ser favorecida devido aos altos custos de mudança na formação de novos hábitos ou alto custo de conquista dos consumidores, construindo vantagens por meio de reputação, aprendizado do consumidor (Suárez e Lanzolla, 2007) e externalidades de redes.

As organizações que investem na atividade de $P \& D$ e inovação se utilizam de um "mix" de mecanismos de apropriabilidade. As empresas devem sempre estabelecer um regime de apropriabilidade para cada projeto colaborativo com empresas, pois a tendência dessas instituições é apenas gerenciar o mecanismo formal de propriedade intelectual, principalmente as patentes. Porém, esse instrumento, quando utilizado isoladamente, não garante a obtenção melhores resultados econômicos, estando condicionado à capacidade de articulá-lo a outros mecanismos para que se obtenha uma maior proteção e lucro com o conhecimento e inovação.

Além disso, os diferentes mecanismos de apropriabilidade interagem entre si de várias maneiras. Por exemplo, alguns mecanismos podem ser pensados como pré-requisitos, desdobramento ou como suporte a outras formas de proteção. Assim, as barreiras técnicas podem ser um requisito para manter um segredo comercial. Patentes ou sigilo podem ajudar a criar vantagens de time-to-market (HurmelinnaLaukkanen e Puumalainen, 2007). 
Diferentes mecanismos também podem ser empregados nas várias etapas do processo de inovação. As empresas podem inicialmente confiar no sigilo antes da comercialização de um novo produto e, mais tarde, solicitar uma patente e/ou exibir estratégias agressivas de marketing e time-to-market. Por sua vez, o time-to-market pode ser usado para obter vantagens na manufatura (movendo-se ao longo da curva de aprendizado e ganhando economias de escala) e marketing (construindo vendas de marketing e capacidades de serviço), e para retardar a imitação por concorrentes (Harabi,1995).

Portanto, mais de um mecanismo pode ser empregado ao mesmo tempo para uma dada tecnologia e inovação quando compreende componentes ou características separadamente passíveis de proteção (Cohen et al., 2000), ou quando a legislação permite um "empilhamento" de direitos de propriedade industrial/intelectual (DPI) sobre a mesma invenção.

Finalmente, a eficácia dos diferentes mecanismos varia ao longo do tempo; segredos comerciais podem ser revelados, patentes expiram e podem ser inventadas em qualquer lugar, entretanto, marcas registradas, por exemplo, podem aumentar drasticamente seu valor e ser renovadas indefinidamente (Hurmelinna e Puumalainen, 2005).

\subsection{4.}

\section{Patentes, marcas e outros métodos formais de proteção}

Com o propósito de resolver o problema da apropriação indevida dos resultados da PD\&I pelos imitadores, incentivando as empresas inovadoras a investirem e desfrutarem dos lucros gerados por suas invenções e/ou inovações, foram criadas legislações que regulamentam o monopólio do inventor, por meio DPI e outros mecanismos. Esses são os meios formais de proteção e são aqueles que concedem proteção jurídica a todas as criações resultantes do espírito humano, seja de caráter científico, industrial, literário ou artístico.

Ocorreram alguns avanços em meados da década de 90 quanto ao sistema de propriedade intelectual vigente no Brasil. Em 1996, foi instituída a nova lei de propriedade industrial brasileira, que substituiu o antigo código de 1971, ampliando a proteção para produtos e processos biotecnológicos, incluindo o patenteamento de genes utilizados na indústria de sementes. 
$\mathrm{Na}$ área de DPI, destacam-se os seguintes instrumentos de proteção: as patentes de invenção, as patentes de modelos de utilidade, desenhos industriais, indicações geográficas, registros de marcas e proteção de cultivares. Além dos DPI, de caráter industrial, existe também o direito autoral que é aquele que protege obras literárias, artísticas e científicas, programas de computador, topografias de circuito integrado, domínios da internet e cultura imaterial. A patente é o principal instrumento de proteção legal utilizado no segmento industrial, por estabelecer direitos de propriedade sobre os resultados do processo de P\&D e inovação, protegendo legalmente os inovadores contra a ação dos imitadores. A empresa ou instituição que detém uma determinada patente mantém o monopólio temporário sobre todos os direitos oriundos da patente e assim desfruta dos retornos que o investimento nessa atividade pode gerar.

Além da proteção contra os imitadores e a obstrução à atividade das empresas concorrentes, as patentes oferecem outras vantagens e representam uma maneira objetiva de se medir o desempenho dos empregados da área de $\mathrm{P} \& \mathrm{D}$, bem como melhoram o poder de negociação das instituições com outras empresas, além de permitirem que a empresa detentora da patente consiga entrar em determinados mercados estrangeiros onde o acesso exige ter contratos de licenciamento com empresas locais.

A patente tende a criar algumas contradições quanto ao caráter de apropriação dos resultados do conhecimento e inovação. Uma delas é a de que a contrapartida da proteção é a difusão do conhecimento protegido, o que capacita a geração de variantes da tecnologia básica. Além disso, a flexibilidade da legislação permite que sejam registrados fragmentos de produtos e/ou processos o que não garante a plenitude da sua aplicação e impede que outras empresas repliquem aquele fragmento para outras aplicações (Buainain et al., 2005).

Além dos DPI, outro instrumento de cunho jurídico que reforça a apropriação dos investimentos em inovações são as estratégias desenvolvidas a partir do estabelecimento da reputação sobre uma marca. Para alguns mercados, a marca constitui-se como um forte fator de diferenciação. Ela indica não somente a qualidade do produto, como também serviços de venda e assistência técnica prestados pelos seus detentores. 
Consumidores que estejam satisfeitos com uma marca serão relutantes em mudar para outras marcas concorrentes se houver a possibilidade de que esses produtos não atinjam ou superem o desempenho do produto adquirido. A incerteza que circunda uma transação, unida aos efeitos da reputação podem transformar a marca de uma empresa ou instituição como uma fonte de apropriabilidade.

Um outro motivo para consolidação do registro de marca como instrumento formal de apropriabilidade, deve-se ao fato de que, para alguns produtos ou serviços reconhecidos pela sua marca, há necessidade de se desenvolver know-how específico para ser confiável, e a mudança para uma outra marca poderia acarretar em custos de aprendizado da tecnologia (conhecimento) e novo produto (inovação) a ser compartilhado com os parceiros estratégicos. Assim, uma instituição ou empresa que queira penetrar em um mercado que possui uma marca confiável estabelecida, será forçada a vender a preços inferiores em relação aos pioneiros. Caso haja falhas com a tecnologia ou produto licenciado/vendido ou serviço prestado, a reputação dos pioneiros será ainda mais fortalecida.

$\mathrm{Na}$ área institucional existem basicamente as legislações pertinentes para proteção do conhecimento e das inovações. Essas leis facilitam o uso de cláusulas de confidencialidade e de segredo industrial nos acordos firmados entre as partes, para explorar plenamente o dever de fidelidade dos envolvidos com o conhecimento e inovações, incorporando sanções relacionadas à quebra do sigilo (Rousseau e Wade-Benzoni, 1994).

\subsection{5.}

\section{Ativos complementares}

A quinta estratégia básica de captura de valor das atividades inovativas enfatiza a importância dos ativos complementares. Trata-se de um conceito pouco explorado na literatura sobre estratégia segundo a visão baseada em recursos (sigla em inglês, RBV). Embora a RBV traga proposições levemente diferentes em diferentes artigos, pode-se dizer, de forma genérica, que ela propõe uma explicação para a vantagem competitiva de uma empresa, que se dá a partir do conjunto específico de recursos internos que ela controla e que a diferencia, positivamente, dos concorrentes. Tais recursos podem ser tangíveis, como equipamentos e unidades produtivas; ou intangíveis, como competências técnicas e organizacionais, bem como direitos de propriedade intelectual (patentes, marcas, dentre outros). 
Nesse contexto, surge talvez a mais importante contribuição de Teece (1986; 2006; 2016) com o seu modelo Profiting from Innovation - PFI. Teece propôs uma taxonomia para ativos e tecnologias complementares, a saber: (I) genéricos; (ii) especializados; e (iii) co-especializados. Os ativos complementares genéricos são ativos de finalidade geral, que não precisam ser adaptados à inovação em questão. Os ativos especializados são aqueles em que há dependência unilateral entre a inovação e o ativo complementar. Os ativos co-especializados são aqueles para os quais há dependência bilateral.

Deve-se levar em conta que a atividade inovativa apenas se completa, quando a inovação é comercializada com sucesso. $\mathrm{Na}$ realização desta etapa, empresas inovadoras também precisam dos ativos complementares necessários para apoiar a atividade inovativa e garantir os benefícios da inovação (Teece, 1986). Estes ativos complementares relacionam-se com as atividades típicas de áreas funcionais das empresas, tais como marketing, produção competitiva, distribuição e suporte pósvenda. Estes ativos tanto podem ser internalizados, quanto contratados a jusante da cadeia produtiva.

Pesquisas empíricas apoiaram amplamente a afirmação básica sobre a importância de ativos complementares especializados em regimes de fraca apropriabilidade. Por exemplo, Levin et al. (1987) e Cohen et al. (2000) destacaram a importância de possuir ativos complementares para capturar valor em indústrias com apropriabilidade relativamente fraca.

Em um estudo setorial detalhado, Helfat (1994) concluiu que as diferenças intraindustriais nas aplicações de $\mathrm{P} \& \mathrm{D}$ das empresas de petróleo e gás estavam associadas a diferentes tipos de ativos complementares usados para comercializar produtos e serviços resultantes de P\&D. Essa especificidade firme em P\&D aumenta a apropriabilidade específica da empresa e torna mais difícil para os rivais imitar os esforços de PD\&I de uma empresa.

Já Rothaermel e Hill (2005) mostram que os ativos complementares genéricos necessários para comercializar uma nova tecnologia geram um desempenho mais baixo do que os ativos complementares especializados.

A natureza do contexto tecnológico também afeta a eficácia do uso de ativos complementares. Quando confrontados com uma descontinuidade tecnológica ou uma mudança tecnológica radical, as empresas que possuem ou controlam ativos 
complementares especializados são mais propensas a sustentar uma vantagem competitiva e desempenho persistente (Rothaermel e Hill, 2005; Tripsas, 1997). Por exemplo, Sorescu, Chandy e Prabhu (2003) demonstraram que as empresas que fornecem maiores níveis de suporte de marketing e de tecnologia obtêm maior desempenho de suas inovações radicais.

Existe uma perspectiva alternativa que considera a apropriabilidade como um fator endógeno. As empresas podem tentar moldar seus regimes de apropriabilidade, alterando seus esforços de PD\&I para otimizar o valor derivado de co-especialização, ou seja, quando o programa de $\mathrm{P} \& \mathrm{D}$ depender de ativos complementares especializados e vice-versa (Teece, 1986; 2006; 2016).

\section{6.}

Arquitetura setorial, intensidade tecnológica e uso de ativos complementares

Enquanto Teece (1986) trata da relação da empresa com um concorrente que ameaça se apropriar do valor de sua inovação, a partir do poder de barganha que possui, Jacobides et al. (2006) buscam dar conta destas relações de poderes de barganha derivados de recursos e apropriação do valor de inovações para todo um setor. Este é um conceito de suma importância para o estudo empírico objeto do capítulo 4 .

O conceito central de Jacobides et al. (2006) é o de "arquitetura setorial" (industry architecture). Os autores mencionam o propósito de lidar com duas repartições feitas entre as organizações de uma cadeia produtiva: o "quem faz o que", ou a divisão do trabalho; e o "quem fica com o que", ou a divisão do excedente econômico.

A primeira aproxima o conceito de arquitetura setorial do conceito de cadeia produtiva, descrevendo a sequência de atividades produtivas que transformam uma série de insumos em determinado produto, identificando, eventualmente, os responsáveis pela realização de cada atividade; uma descrição, justamente, da divisão (técnica) do trabalho naquele setor.

A segunda, por sua vez, alinha o texto com o modelo de Teece (1986), uma vez que explica a apropriação do excedente com base no poder de barganha derivado dos recursos controlados pelos agentes, em particular no caso de inovações às quais determinados ativos são complementares. Em sua abordagem, 
Teece apresenta três bases conceituais que influenciam a capacidade que um inovador possui de colher os frutos de sua inovação: o regime de apropriação; o projeto dominante (dominant design); e os ativos complementares.

A classificação dos setores de atividade de acordo com seus padrões tecnológicos permite resumir a estrutura produtiva em um número relativamente reduzido de categorias, facilitando o processamento e a análise de um volume extenso de informações.

As duas classificações tecnológicas mais amplamente empregadas por formuladores de políticas e por pesquisadores da área de economia da inovação são: (i) a classificação da Organização para a Cooperação e Desenvolvimento Econômico (OCDE), que agrupa os setores da indústria de transformação de acordo com sua intensidade tecnológica (alta, média-alta, média-baixa e baixa); e (ii) a taxonomia originalmente proposta por Pavitt (1984), que considera os padrões setoriais de mudança técnica e que, em seu formato original, considera quatro categorias: dominados pelos fornecedores, intensivos em escala, fornecedores especializados (ou difusores do progresso técnico) e baseados em ciência.

A utilização de classificações tecnológicas, na prática, pressupõe que se associe, a cada setor de atividade, um dos grupos definidos. Essa nem sempre é uma tarefa trivial porque as empresas que compõem um dado setor de atividade podem ter padrões tecnológicos distintos. Esse problema tende a agravar-se quando se usam setores mais agregados. No caso das firmas, a classificação tecnológica se aplica pela presença de níveis elevados de heterogeneidade intrassetorial, de modo que há o argumento para uma categorização padronizada específica às firmas (Archibugi, 2001; Cavalcante, 2014).

A classificação tecnológica da OCDE por intensidade tecnológica foi registrada por Hatzichronoglou (1997), que menciona as iniciativas precedentes adotadas no âmbito daquela organização e propõe um critério que considera tanto o nível de tecnologia específico do setor quanto o valor agregado e a tecnologia incorporada nas compras de bens intermediários e de capital. Mais recentemente a classificação da OCDE tem se restringido aos gastos em P\&D para classificar os setores. Baseada no indicador de intensidade de P\&D (gasto em P\&D/valor agregado ao produto ou gasto em P\&D/processo), a OCDE (2011) classifica os setores em quatro grupos principais de intensidade tecnológica, a saber: 
- Alta intensidade tecnológica: setores aeroespaciais; farmacêutico; de informática; eletrônica e telecomunicações; instrumentos;

- Média-alta intensidade tecnológica: setores de material elétrico; veículos automotores; química, excluído o setor farmacêutico; ferroviário e de equipamentos de transporte; máquinas e equipamentos;

- Média-baixa intensidade tecnológica: setores de construção naval; borracha e produtos plásticos; coque, produtos refinados de petróleo e de combustíveis nucleares; outros produtos não metálicos; metalurgia básica e produtos metálicos;

- Baixa intensidade tecnológica: outros setores e de reciclagem, madeira, papel e celulose; editorial e gráfica; alimentos, bebidas e fumo; têxtil e de confecção, couro e calçados.

Esta classificação é adotada no estudo empírico apresentado no capítulo 4, considerando-se diferentes condições setoriais e distintas características internas das empresas inovadoras. Para a definição dos agrupamentos setoriais, classificamse os setores da indústria de transformação segundo intensidade tecnológica, adotando-se a taxonomia da OCDE (2011) e calcula-se a força do regime de apropriabilidade pelo uso dos mecanismos de proteção (formais e informais) pelas empresas de cada setor, a partir de dados da Pintec 2008.

\section{7.}

\section{Análise dos estudos empíricos sobre cooperação interorganizacional e apropriação de valor}

O quadro 2.1, a seguir, sintetiza os objetivos, fontes de dados e amostra; país/região; variáveis e métodos de análise adotados em 26 estudos empíricos sobre os temas centrais desta dissertação, na perspectiva de se identificar as principais lacunas de pesquisa, que serão abordadas no estudo empírico focalizando empresas da indústria de transformação no Brasil que inovaram no período 2012-2014. 
Quadro 2.1 - Quadro-síntese dos estudos empíricos sobre os temas centrais da pesquisa: cooperação interorganizacional em projetos de inovação e apropriação de valor pela criação de inovações

\begin{tabular}{|c|c|c|c|c|c|c|}
\hline Ref. & Autores & Objetivo do estudo empírico & Fonte de dados/amostra & $\begin{array}{c}\text { País ou região/ } \\
\text { setores abordados }\end{array}$ & Variáveis & $\begin{array}{l}\text { Métodos } \\
\text { adotados }\end{array}$ \\
\hline $\mathrm{CO} 1$ & Bayona et al. (2001) & $\begin{array}{l}\text { Analisar as razões que levam as empresas } \\
\text { da indústria de transformação a cooperarem } \\
\text { em projetos de P\&D e os fatores que } \\
\text { condicionam a cooperação } \\
\text { interorganizacional. }\end{array}$ & \begin{tabular}{|l|} 
Fonte: Pesquisa de Inovação \\
Tecnológica na Espanha \\
(1996) \\
Amostra: 1.652 empresas que \\
realizaram atividades de P\&D.
\end{tabular} & $\begin{array}{l}\text { País/região: } \\
\text { Espanha/ Europa } \\
\text { Setor(es): } \\
\text { Indústria de } \\
\text { transformação. }\end{array}$ & $\begin{array}{l}\text { Tipos de cooperação em P\&D; } \\
\text { complexidade da tecnologia; capacidade } \\
\text { absortiva (conhecimento de mercado, } \\
\text { riscos e recursos financeiros); tamanho } \\
\text { das empresas }\end{array}$ & $\begin{array}{l}\text { Estatística } \\
\text { descritiva } \\
\text { Regressão } \\
\text { logística }\end{array}$ \\
\hline $\mathrm{CO} 2$ & Tether (2002) & $\begin{array}{l}\text { Investigar os padrões de cooperação entre } \\
\text { empresas inovadoras e parceiros externos, } \\
\text { analisando aspectos do tipo da empresa } \\
\text { parceira e do que se entende por inovação. }\end{array}$ & $\begin{array}{l}\text { Fonte: Pesquisa Europeia } \\
\text { sobre Cooperação em } \\
\text { Inovação (CIS-2) de } 1997 \\
\text { Amostra: } 2.342 \text { empresas, } \\
\text { sendo } 1.598 \text { (68\%) de setores } \\
\text { de transformação; e } 744(32 \%) \\
\text { de setores de serviços. }\end{array}$ & $\begin{array}{l}\text { Pais/região: } \\
\text { Reino Unido / } \\
\text { Europa } \\
\text { Setor(es): } \\
\text { Indústria de } \\
\text { transformação e } \\
\text { serviços. }\end{array}$ & $\begin{array}{l}\text { Tipos de cooperação em P\&D; tipo de } \\
\text { empresa parceira, abrangência da } \\
\text { inovação, tipo de inovação; capacidade } \\
\text { absortiva; tamanho e características das } \\
\text { empresas }\end{array}$ & $\begin{array}{l}\text { Análise } \\
\text { multivariada } \\
\text { Regressão } \\
\text { logística }\end{array}$ \\
\hline $\mathrm{CO} 3$ & Sáez et al. (2002) & $\begin{array}{l}\text { Compreender as razões que levam as } \\
\text { empresas a cooperar com universidades e } \\
\text { centros de pesquisa e as características da } \\
\text { relação que isso envolve. }\end{array}$ & $\begin{array}{l}\text { Fonte: Pesquisa de Inovação } \\
\text { Tecnológica (1996) } \\
\\
\text { Amostra: } 747 \text { empresas que } \\
\text { participaram de algum tipo de } \\
\text { projeto colaborativo em P\&D. }\end{array}$ & $\begin{array}{l}\text { País/região: } \\
\text { Espanha/ Europa } \\
\text { Setor(es): } \\
\text { Indústria de } \\
\text { transformação. }\end{array}$ & $\begin{array}{l}\text { Variável dependente: Tipo de empresa } \\
\text { parceira (universidades e centros de } \\
\text { pesquisa); tipo de empresa parceira; } \\
\text { tamanho das empresas; intensidade } \\
\text { tecnológica (classificação de Pavitt); } \\
\text { impactos da inovação }\end{array}$ & $\begin{array}{l}\text { Teste de } \\
\text { hipóteses } \\
\text { Regressão } \\
\text { logística }\end{array}$ \\
\hline $\mathrm{CO} 4$ & $\begin{array}{l}\text { Bönte e Keilbach } \\
(2005)\end{array}$ & $\begin{array}{l}\text { Investigar sobre os fatores determinantes } \\
\text { nas escolhas, pelas empresas inovadoras, } \\
\text { dentre os diferentes modos de cooperação } \\
\text { (formais e informais) de sua cadeia de } \\
\text { suprimento vertical. }\end{array}$ & $\begin{array}{l}\text { Fonte: } 1^{\circ} \text { e } 2^{\circ} \text { Levantamentos } \\
\text { do Painel de Inovação de } \\
\text { Mannheim/ Alemanha (1993 e } \\
\text { 1994) } \\
\text { Amostra: } 2.860 \text { ( } 1^{\circ} \\
\text { levantamento); e } 3.065 \\
\text { empresas (2॰ levantamento) }\end{array}$ & \begin{tabular}{|l} 
País/região: \\
Alemanha/Europa \\
Setor (es): \\
Empresas da cadeia \\
de suprimento \\
vertical
\end{tabular} & $\begin{array}{l}\text { Tipos de cooperação em P\&D (clientes e } \\
\text { fornecedores/formais e informais); tipos } \\
\text { de transbordamentos do conhecimento } \\
\text { (adquiridos e disponibilizados); } \\
\text { mecanismos de apropriabilidade; } \\
\text { capacidade absortiva; intensidade } \\
\text { tecnológica características das empresas } \\
\text { (tamanho, localização, estrutura } \\
\text { organizacional de P\&D e a dinâmica de } \\
\text { inovação do mercado) }\end{array}$ & $\begin{array}{l}\text { Estatística } \\
\text { descritiva } \\
\text { Teste de } \\
\text { hipóteses } \\
\text { Regressão } \\
\text { logística }\end{array}$ \\
\hline $\mathrm{CO} 5$ & $\begin{array}{l}\text { Veugelers e Cassiman } \\
\text { (2005) }\end{array}$ & $\begin{array}{l}\text { Analisar quais características da empresa e } \\
\text { da indústria são propícias à cooperação com } \\
\text { universidades. }\end{array}$ & $\begin{array}{l}\text { Fonte; Pesquisa da } \\
\text { comunidade belga de } \\
\text { inovação (conduzida pela } \\
\text { Eurostat com os diferentes } \\
\text { membros em } 1993 \text { (CIS-I) com } \\
325 \text { empresas que inovaram, } \\
\text { sendo a amostra de } 87 \\
\text { empresas que têm parcerias } \\
\text { com universidades. }\end{array}$ & $\begin{array}{l}\text { País/região: } \\
\text { Bélgica/ Europa } \\
\text { Setores: } \\
\text { Indústria de } \\
\text { transformação. }\end{array}$ & $\begin{array}{l}\text { Variáveis explanatórias: características } \\
\text { das empresas (tamanho, capacidade de } \\
\text { P\&D e se nacional ou estrangeira); } \\
\text { capacidade absortiva (riscos, base } \\
\text { científica e recursos financeiros); ativos } \\
\text { complementares e mecanismos de } \\
\text { apropriabilidade. }\end{array}$ & $\begin{array}{l}\text { Estatística } \\
\text { descritiva } \\
\text { Regressão } \\
\text { logística }\end{array}$ \\
\hline
\end{tabular}


Quadro 2.1 - Quadro-síntese dos estudos empíricos sobre os temas centrais da pesquisa: cooperação interorganizacional em projetos de inovação e apropriação de valor pela criação de inovações (cont.)

\begin{tabular}{|c|c|c|c|c|c|c|}
\hline Ref. & Autores & Objetivo do estudo empírico & Fonte de dados/amostra & $\begin{array}{l}\text { País ou região/ setores } \\
\text { abordados }\end{array}$ & Variáveis & $\begin{array}{l}\text { Métodos de análise } \\
\text { adotados }\end{array}$ \\
\hline $\mathrm{CO} 6$ & $\begin{array}{l}\text { Silva et al. } \\
(2005)\end{array}$ & $\begin{array}{l}\text { Investigar se os relacionamentos } \\
\text { estabelecidos entre as empresas e seus } \\
\text { parceiros no âmbito da inovação } \\
\text { influenciam de forma significativa a } \\
\text { capacidade inovadora das empresas } \\
\text { industriais portuguesas, no nível dos } \\
\text { avanços inovadores empreendidos em } \\
\text { termos de inovações de produto. }\end{array}$ & $\begin{array}{l}\text { Fonte: Inquérito } \\
\text { Comunitário à Inovação - } \\
\text { CIS } 1999 \\
\text { Amostra: inicial - } 1.556 \\
\text { empresas industriais } \\
\text { Amostra ajustada: } 1.429 \\
\text { empresas }\end{array}$ & \begin{tabular}{|l|} 
País/região: \\
Portugal/ \\
Europa \\
Setor(es): \\
Setores industrais \\
cobertos pelo Inquérito \\
Comunitário à Inovação \\
- CIS 1999, segundo \\
CAE.
\end{tabular} & $\begin{array}{l}\text { Variável dependente: avanços inovadores } \\
\text { Variáveis explanatórias: relacionamentos com } \\
\text { clientes, fornecedores e emrpesas do grupo; } \\
\text { relacionamentos com concorrentes; } \\
\text { relacioanmentos com universidades e OlEs; } \\
\text { relacionamentos com instituições de investigação } \\
\text { e empresas de consultoria. }\end{array}$ & $\begin{array}{l}\text { Estatística descritiva } \\
\text { Regressão logística }\end{array}$ \\
\hline $\mathrm{CO} 7$ & $\begin{array}{l}\text { Arranz; } \\
\text { Arroyabe } \\
\text { (2008) }\end{array}$ & $\begin{array}{l}\text { Analisar os determinantes para a escolha } \\
\text { de parceiros entre empresas que } \\
\text { cooperam em P\&D. }\end{array}$ & $\begin{array}{l}\text { Fonte: Spanish } \\
\text { Community Innovation } \\
\text { Survey } 1997 \text { (CIS-2), } \\
\text { conduzida pelo Instituto } \\
\text { Nacional de Estatística } \\
\text { (INE). } \\
\text { Amostra: } 1.652 \text { empresas. }\end{array}$ & $\begin{array}{l}\text { País/região: Espanha/ } \\
\text { Europa } \\
\text { Setores: } \\
\text { Indústria de } \\
\text { transformação. }\end{array}$ & $\begin{array}{l}\text { Variável dependente: tipos de parceiros em } \\
\text { cooperação em P\&D (vertical ou horizontal); } \\
\text { intensidade tecnológica. } \\
\text { Variável explanatória: capacidade absortiva } \\
\text { (riscos e custo). }\end{array}$ & $\begin{array}{l}\text { Estatística descritiva } \\
\text { Teste de hipóteses } \\
\text { Análise de } \\
\text { regressão } \\
\text { hierárquica }\end{array}$ \\
\hline $\mathrm{CO} 8$ & $\begin{array}{l}\text { Lhuillery; } \\
\text { Pfister } \\
\text { (2009) }\end{array}$ & $\begin{array}{l}\text { Analisar a ocorrência de falhas na } \\
\text { cooperação interorganizacional para } \\
\text { inovação. }\end{array}$ & $\begin{array}{l}\text { Fonte: French Community } \\
\text { Innovation Survey (CIS-2) } \\
\text { Amostra: } 2.354 \text { empresas. }\end{array}$ & $\begin{array}{l}\text { País/região: } \\
\text { França/Europa } \\
\text { Setor(es): } \\
\text { Indústria de } \\
\text { transformação } \\
\end{array}$ & $\begin{array}{l}\text { Variáveis dependentes: Falha na cooperação } \\
\text { Variáveis explanatórias: tipo de empresa } \\
\text { parceira; experiência do parceiro; regime de } \\
\text { apropriabilidade; características das empresas; } \\
\text { intensidade tecnológica setorial (OCDE). }\end{array}$ & $\begin{array}{l}\text { Estatística descritiva } \\
\text { Análise de } \\
\text { regressão } \\
\text { Modelo Probit }\end{array}$ \\
\hline $\operatorname{cog}$ & $\begin{array}{l}\text { Capaldo; } \\
\text { Petruzzelli } \\
\text { (2011) }\end{array}$ & $\begin{array}{l}\text { Investigar como o conhecimento } \\
\text { tecnológico em diferentes domínios afeta } \\
\text { a criação de valor e apropriação de valor } \\
\text { em arranjos cooperativos para PD\&I. }\end{array}$ & $\begin{array}{l}\text { Fontes: Banco de dados } \\
\text { de patentes; International } \\
\text { Patent Classification } \\
\text { (IPC3). } \\
\text { Amostra: } 10 \text { empresas do } \\
\text { setor de equipamentos } \\
\text { elétricos e eletrônicos } \\
\text { mais inovadoras, em } \\
\text { termos de patentes } \\
\text { concedidas. }\end{array}$ & $\begin{array}{l}\text { País/Região: } \\
\text { Itália/ Europa } \\
\text { Setor (es): fabricantes } \\
\text { de equipamentos } \\
\text { elétricos e eletrônicos } \\
\text { (EEE) }\end{array}$ & $\begin{array}{l}\text { Variáveis dependentes: criação de valor; } \\
\text { apropriação de valor } \\
\text { Variáveis explanatórias: conhecimento } \\
\text { tecnológico em diferentes domínios (IPC3); } \\
\text { número de patentes conjuntas; } \\
\text { Variáveis de controle: tamanho da empresa; } \\
\text { capital tecnológico; tamanho da equipe; diferença } \\
\text { cultural entre os envolvidos nas patentes; } \\
\text { existência de alianças anteriores de P\&D entre } \\
\text { as organizações envolvidas e tempo de aliança }\end{array}$ & $\begin{array}{l}\text { Estatística descritiva } \\
\text { Análise de } \\
\text { regressão }\end{array}$ \\
\hline Co10 & $\begin{array}{l}\text { Hurmelinna- } \\
\text { Laukkanen } \\
\text { (2011) }\end{array}$ & $\begin{array}{l}\text { Analisar e discutir o papel da proteção de } \\
\text { novos conhecimentos em relação a } \\
\text { arranjos cooperativos em projetos de } \\
\text { PD\&I. }\end{array}$ & $\begin{array}{l}\text { Fonte: Blue Book } \\
\text { Database. Coleta feita via } \\
\text { pesquisa survey junto às } \\
\text { empresas na web, } \\
\text { cobrindo o período } 2008 \text { e } \\
2009 . \\
\text { Amostra: } 242 \text { empresas } \\
\text { finlandesas, com pelo } \\
\text { menos } 50 \text { empregados. }\end{array}$ & $\begin{array}{l}\text { País/Região: Finlândia/ } \\
\text { Europa } \\
\text { Setor(es): diversos. }\end{array}$ & $\begin{array}{l}\text { Variável dependente: desempenho inovador; } \\
\text { compartilhamento de conhecimento. } \\
\text { Variáveis explanatórias e de controle: força do } \\
\text { regime de apropriabilidade; condições setoriais; } \\
\text { tamanho da empresa; idade da empresa; } \\
\text { intensidade em P\&D. }\end{array}$ & $\begin{array}{l}\text { Estatística descritiva } \\
\text { Teste de hipóteses } \\
\text { Método de } \\
\text { correlação de } \\
\text { Pearson } \\
\text { Análise de } \\
\text { regressão (Baron e } \\
\text { Kenny, 1986). }\end{array}$ \\
\hline
\end{tabular}


Quadro 2.1 - Quadro-síntese dos estudos empíricos sobre os temas centrais da pesquisa: cooperação interorganizacional em projetos de inovação e apropriação de valor pela criação de inovações (cont.)

\begin{tabular}{|c|c|c|c|c|c|c|}
\hline Ref. & Autores & Objetivo do estudo empírico & Fonte de dados/amostra & \begin{tabular}{|l|}
$\begin{array}{l}\text { País ou região/ } \\
\text { setores abordados }\end{array}$ \\
\end{tabular} & Variáveis & $\begin{array}{l}\text { Métodos de } \\
\text { análise adotados }\end{array}$ \\
\hline Co11 & Wu (2012) & $\begin{array}{l}\text { Avaliar em que medida a } \\
\text { colaboração tecnológica em } \\
\text { inovações de produto dependem } \\
\text { das condições competitivas do } \\
\text { mercado em que as empresas } \\
\text { inovadoras atuam e nas } \\
\text { características tecnológicas } \\
\text { setoriais. }\end{array}$ & $\begin{array}{l}\text { Fonte: Pesquisa realizada pelo } \\
\text { Banco Mundial em colaboração } \\
\text { com a Enterprise Survey } \\
\text { Organization do Departamento } \\
\text { Nacional de Estatísticas da China. } \\
\text { Amostra: } 944 \text { empresas de cinco } \\
\text { setores da indústria de } \\
\text { transformação. }\end{array}$ & $\begin{array}{l}\text { País/Região: } \\
\text { China/Ásia } \\
\\
\text { Setor(es): } \\
\text { Cinco setores da } \\
\text { indústria de } \\
\text { transformação }\end{array}$ & $\begin{array}{l}\text { Variável dependente: percentual das } \\
\text { vendas totais contabilizadas pelas } \\
\text { vendas de novos produtos (vendas de } \\
\text { novos produtos ou não) } \\
\text { Variáveis explanatórias: condições } \\
\text { competitivas dos setores em que as } \\
\text { empresas atuam; intensidade } \\
\text { tecnológica setorial. }\end{array}$ & $\begin{array}{l}\text { Análise de } \\
\text { regressão de } \\
\text { Poisson } \\
\text { Regressão } \\
\text { logística }\end{array}$ \\
\hline Co12 & Pires (2013) & $\begin{array}{l}\text { Analisar qual a influência dos } \\
\text { determinantes da inovação, } \\
\text { entendendo-se como determinantes } \\
\text { da inovação as fontes de } \\
\text { informação, a cooperação com os } \\
\text { vários parceiros de negócio e } \\
\text { ciência e os investimentos } \\
\text { e despesas em actividades de } \\
\text { inovação no desempenho inovador, } \\
\text { ao nível do produto e ao } \\
\text { nível organizacional. } \\
\end{array}$ & $\begin{array}{l}\text { Fonte: Inquérito Comunitário à } \\
\text { Inovação - CIS } 2008 \\
\text { Amostra: } 6.512 \text { empresas }\end{array}$ & \begin{tabular}{|l} 
País/região: \\
Portugal/ \\
Europa \\
Setor(es): \\
Seções B; C; D; E; \\
F; G; H; J; K; M da \\
CAE - Rev. 3, \\
sector industrial e \\
de comércio e \\
serviços. \\
\end{tabular} & $\begin{array}{l}\text { Variáveis dependentes: inovação de } \\
\text { produto; inovação organizacional. } \\
\text { Variáveis explanatórias: } \\
\text { fontes de informação; cooperação no } \\
\text { âmbito da inovação; investimentos e as } \\
\text { despesas em atividades de inovação e } \\
\text { de P\&D. }\end{array}$ & $\begin{array}{l}\text { Estatística } \\
\text { descritiva } \\
\text { Regressão } \\
\text { logística }\end{array}$ \\
\hline Co13 & $\begin{array}{l}\text { Spithovena; Teirlinck } \\
\text { (2015) }\end{array}$ & $\begin{array}{l}\text { Contribuir para uma validação } \\
\text { empírica da terceirização de P\&D, } \\
\text { integrando a influência de } \\
\text { capacidades internas, recursos de } \\
\text { rede e mecanismos de apropriação } \\
\text { e discutindo os determinantes da } \\
\text { terceirização de P\&D. }\end{array}$ & $\begin{array}{l}\text { Fonte: } 3^{\mathrm{a}} \text { e } 4^{\mathrm{a}} \text { Pesquisas de } \\
\text { Inovaçâo da Comunidade Europeia } \\
\text { para a Bélgica com uma amostra } \\
\text { de (CIS-3 e CIS-4). } \\
\text { Amostra: } 601 \text { empresas presentes } \\
\text { nas duas pesquisas, com } 10 \text { ou } \\
\text { mais empregados. }\end{array}$ & $\begin{array}{l}\text { País/Região: } \\
\text { Bélgica/Europa. } \\
\text { Setor(es): } \\
\text { Não identificados. }\end{array}$ & $\begin{array}{l}\text { Variável dependente: intensidade de } \\
\text { terceirização de P\&D. } \\
\text { Variáveis explanatórias: capacidades } \\
\text { internas, recursos de rede e mecanismos } \\
\text { de apropriação (preditoras) e intensidade } \\
\text { das exportações, tamanho e } \\
\text { características da empresa (controle) } \\
\text { Variáveis binárias: spillovers de } \\
\text { conhecimento ou aquisição complexa de } \\
\text { conhecimento; recursos de rede } \\
\text { (coopera ou não); patentes (possui ou } \\
\text { não); apropriação (formal ou informal). }\end{array}$ & $\begin{array}{l}\text { Estatística } \\
\text { descritiva } \\
\text { Análise de } \\
\text { regressão }\end{array}$ \\
\hline CO14 & Czarnitzki et al. (2015) & $\begin{array}{l}\text { Mostrar que, dependendo do tipo de } \\
\text { parceiro em arranjos colaborativos } \\
\text { e do tamanho da empresa, } \\
\text { incertezas relacionadas a direitos } \\
\text { de propriedade intelectual (DPI) } \\
\text { levam à redução da cooperação } \\
\text { interorganizacional e podem, } \\
\text { portanto, impedir a produção de } \\
\text { novos conhecimentos e inovações. }\end{array}$ & $\begin{array}{l}\text { Fonte: Painel de Inovação de } \\
\text { Mannheim (PIM), parte da German } \\
\text { Community Innovation Survey } \\
\text { (CIS). } \\
\text { Amostra: } 1.817 \text { empresas. }\end{array}$ & \begin{tabular}{|l|} 
País/Região: \\
Alemanhal \\
Europa. \\
Setor(es): \\
Indústria de \\
transformação.
\end{tabular} & $\begin{array}{l}\text { Variável dependente: capacidade } \\
\text { absortiva } \\
\text { Variáveis de controle (binárias): custos, } \\
\text { riscos e incertezas do processo de } \\
\text { inovação (obstáculos à inovação) e } \\
\text { spillovers de conhecimento. } \\
\text { Variáveis explanatórias: mecanismos de } \\
\text { proteção formal; mecanismos de } \\
\text { proteção informal. } \\
\text { Variáveis de controle: tamanho da } \\
\text { empresa e intensidade de P\&D. }\end{array}$ & $\begin{array}{l}\text { Estatística } \\
\text { descritiva } \\
\text { Regressão Probit }\end{array}$ \\
\hline
\end{tabular}


Quadro 2.1 - Quadro-síntese dos estudos empíricos sobre os temas centrais da pesquisa: cooperação interorganizacional em projetos de inovação e apropriação de valor pela criação de inovações (cont.)

\begin{tabular}{|c|c|c|c|c|c|c|}
\hline Ref. & Autores & Objetivo do estudo empírico & Fonte de dados/amostra & $\begin{array}{l}\text { País ou região/ } \\
\text { setores abordados }\end{array}$ & Variáveis & $\begin{array}{l}\text { Métodos de } \\
\text { análise adotados }\end{array}$ \\
\hline CO15 & $\begin{array}{l}\text { Henttonen; } \\
\text { Hurmelinna- } \\
\text { Laukkanen; Ritala, } \\
(2016)\end{array}$ & $\begin{array}{l}\text { Fornecer novas evidências sobre a } \\
\text { relação entre os diferentes } \\
\text { mecanismos de apropriabilidade } \\
\text { (formais e informais) e a propensão } \\
\text { da empresa em se envolver na } \\
\text { colaboração de P\&D com várias } \\
\text { partes interessadas. }\end{array}$ & $\begin{array}{l}\text { Fonte: Banco de dados Amadeus. } \\
\text { Coleta feita via pesquisa survey } \\
\text { junto às empresas na web, } \\
\text { cobrindo o período } 2008 \text { e } 2009 \text {. } \\
\text { Amostra: } 209 \text { empresas de grande } \\
\text { porte (67 empresas de } \\
\text { transformação; } 40 \text { máquinas e } \\
\text { veículos; } 31 \text { tecnologia da } \\
\text { informação e comunicação e } \\
\text { eletrônica; } 24 \text { atacado, varejo e } \\
\text { logística; } 15 \text { construção civil; e } 32 \\
\text { serviços. } 149 \text { empresas relataram } \\
\text { ter pelo menos algumas atividades } \\
\text { no exterior). }\end{array}$ & $\begin{array}{l}\text { País/Região: } \\
\text { Finlândia/ } \\
\text { Europa } \\
\\
\text { Setor(es): } \\
\text { Diversos. }\end{array}$ & $\begin{array}{l}\text { Variáveis dependentes: colaboração em } \\
\text { P\&D em diversos níveis } \\
\text { Variáveis explanatórias: tipo de empresa } \\
\text { parceira; tipos de cooperação em P\&D; } \\
\text { regime de apropriabilidade (\# uso de } \\
\text { diferentes mecanismos) } \\
\text { Variáveis de controle: intensidade de } \\
\text { P\&D; idade da empresa; tamanho da } \\
\text { empresa. }\end{array}$ & $\begin{array}{l}\text { Análises da } \\
\text { variância } \\
\text { (ANOVA) } \\
\text { Uso de T-test } \\
\text { Análise de } \\
\text { regressão }\end{array}$ \\
\hline $\mathrm{CO} 16$ & $\begin{array}{l}\text { Veer; Lorenz; Blind } \\
(2016)\end{array}$ & $\begin{array}{l}\text { Investigar o papel do regime de } \\
\text { apropriabilidade na cooperação } \\
\text { interorganizacional em projetos de } \\
\text { inovação, visando mitigar imitações. }\end{array}$ & $\begin{array}{l}\text { Fonte: German Community } \\
\text { Innovation Survey (CIS) } \\
\text { Amostra: } 2.797 \text { empresas }\end{array}$ & \begin{tabular}{|l|} 
País/região: \\
Alemanha/ \\
Europa \\
Setor(es): \\
Indústria de \\
transformação
\end{tabular} & $\begin{array}{l}\text { Variável dependente: imitação. } \\
\text { Variáveis explanatórias: uso de } \\
\text { mecanismos formais de proteção; uso } \\
\text { de contratos com parceiros; } \\
\text { Variáveis categóricas: escopo da } \\
\text { inovação aberta (\# diferentes estágios } \\
\text { do funil de inovação) } \\
\text { Espectro da inovação aberta (\# } \\
\text { diferentes tipos de parceiros) } \\
\text { Variáveis de controle: faixas de pessoal } \\
\text { alocado; intensidade de P\&D (\%); } \\
\text { intensidade de exportações (\%); estoque } \\
\text { de patentes; estoque de marcas; valor } \\
\text { da propriedade intelectual; experiência } \\
\text { legal; controle da indústria. }\end{array}$ & $\begin{array}{l}\text { Estatística } \\
\text { descritiva } \\
\text { Regressão } \\
\text { logística }\end{array}$ \\
\hline $\mathrm{CO} 17$ & Moura (2016) & $\begin{array}{l}\text { Caraterizar os determinantes que } \\
\text { influenciam o processo de inovação } \\
\text { nas empresas portuguesas para } \\
\text { cada um dos tipos de inovação } \\
\text { (produto, processo, organizacional } \\
\text { ou de marketing) e identificar e } \\
\text { descrever o papel da cooperação } \\
\text { interorganizacional no desempenho } \\
\text { inovador das empresas. }\end{array}$ & $\begin{array}{l}\text { Fonte: Inquérito Comunitário à } \\
\text { Inovação - CIS } 2010 \\
\text { Amostra: } 6.160 \text { empresas }\end{array}$ & \begin{tabular}{|l} 
País/região: \\
Portugal/ \\
Europa \\
\\
Setor(es): \\
Setores cobertos \\
pelo Inquérito \\
Comunitário à \\
Inovação - CIS \\
2010, segundo \\
Classificação da \\
Atividade \\
Econômica (CAE)
\end{tabular} & $\begin{array}{l}\text { Variável dependente: desempenho } \\
\text { inovador } \\
\text { Variáveis explanatórias: cooperação } \\
\text { interorganizacional; políticas públicas; e } \\
\text { capacidade de absorção. }\end{array}$ & $\begin{array}{l}\text { Estatística } \\
\text { descritiva } \\
\text { Regressão } \\
\text { logística }\end{array}$ \\
\hline
\end{tabular}


Quadro 2.1 - Quadro-síntese dos estudos empíricos sobre os temas centrais da pesquisa: cooperação interorganizacional em projetos de inovação e apropriação de valor pela criação de inovações (cont.)

\begin{tabular}{|c|c|c|c|c|c|c|}
\hline Ref. & Autores & Objetivo do estudo empírico & Fonte de dados/amostra & \begin{tabular}{|l|} 
País ou região/ \\
setores abordados
\end{tabular} & Variáveis & $\begin{array}{l}\text { Métodos de } \\
\text { análise adotados }\end{array}$ \\
\hline CO18 & Pereira (2017) & $\begin{array}{l}\text { Analisar a importância dos } \\
\text { diferentes tipos de parceiros e o } \\
\text { fator localização nas relações } \\
\text { interorganizacionais de empresas } \\
\text { inovadoras no Brasil. }\end{array}$ & $\begin{array}{l}\text { Fonte: Pesquisa de Inovação } \\
\text { (PINTEC) dos anos de 2003, 2005, } \\
\text { 2008, 2011 e } 2014 \\
\text { Amostra: } 490 \text { empresas. }\end{array}$ & \begin{tabular}{|l|} 
País/região: \\
Brasil/América \\
Latina \\
\\
Setor(es): \\
28 atividades \\
empresariais \\
brasileiras
\end{tabular} & $\begin{array}{l}\text { Variáveis dependentes: imitação em } \\
\text { produto; imitação em processo. } \\
\text { Variáveis explanatórias: tipos de } \\
\text { parceiros em diversas localizações } \\
\text { geográficas } \\
\text { Variáveis de controle: atividades } \\
\text { inovativas (P\&D interno, aquisição de } \\
\text { máquinas/equipamentos e treinamento); } \\
\text { Receita líquida de vendas. }\end{array}$ & $\begin{array}{l}\text { Estatística } \\
\text { descritiva } \\
\text { Análise de } \\
\text { regressão em } \\
\text { painel }\end{array}$ \\
\hline Co19 & Lorenz; Veer (2019) & $\begin{array}{l}\text { Investigar a relação entre a } \\
\text { apropriação indevida prévia de } \\
\text { propriedade intelectual protegida e } \\
\text { desprotegida (PI) e a colaboração } \\
\text { em P\&D. }\end{array}$ & $\begin{array}{l}\text { Fonte: German Community } \\
\text { Innovation Survey (CIS) e dados de } \\
\text { patentes e de entrevistas } \\
\text { qualitativas } \\
\text { Amostra: } 630 \text { empresas }\end{array}$ & $\begin{array}{l}\text { País/região: } \\
\text { Alemanha/ Europa } \\
\\
\text { Setor(es): } \\
\text { Indústria de } \\
\text { transformação }\end{array}$ & $\begin{array}{l}\text { Variável dependente: colaboração em } \\
\text { P\&D } \\
\text { Variáveis explanatórias: uso de } \\
\text { mecanismos formais de proteção (PI) - } \\
\text { apropriação indevida por imitação e } \\
\text { violação, } \\
\text { Variáveis de controle: tamanho das } \\
\text { empresas; intensidade em P\&D e } \\
\text { intensidade de exportaçães (volume de } \\
\text { negócios); intensidade tecnológica } \\
\text { (OCDE); setor industrial (nível de } \\
\text { colaboração do setor); custos e riscos, } \\
\text { falta de oportunidades e obstáculos de } \\
\text { mercado à inovação; ciclo de vida do } \\
\text { produto; localização da empresa; } \\
\text { crescimento retração da empresa } \\
\text { Outras variáveis: valor da Pl; } \\
\text { capacidade legal e estratégias de PI. }\end{array}$ & $\begin{array}{l}\text { Regressão } \\
\text { logística }\end{array}$ \\
\hline
\end{tabular}


Quadro 2.1 - Quadro-síntese dos estudos empíricos sobre os temas centrais da pesquisa: cooperação interorganizacional em projetos de inovação e apropriação de valor pela criação de inovações (cont.)

\begin{tabular}{|c|c|c|c|c|c|c|}
\hline Ref. & Autores & Objetivo do estudo empírico & Fonte de dados/amostra & \begin{tabular}{|l|}
$\begin{array}{l}\text { País ou região/ } \\
\text { setores abordados }\end{array}$ \\
\end{tabular} & Variáveis & $\begin{array}{l}\text { Métodos de } \\
\text { análise adotados }\end{array}$ \\
\hline AP1 & Van Dijk (2000) & $\begin{array}{l}\text { Analisar as correlações entre as } \\
\text { propriedades estruturais e } \\
\text { dinâmicas de diferentes setores da } \\
\text { indústria e seus regimes } \\
\text { tecnológicos. }\end{array}$ & $\begin{array}{l}\text { Fonte: Statistics Netherlands } \\
\text { Manufacturing Database. } \\
\text { Amostra: } 2.838 \text { com informação } \\
\text { contínua no período } 1978 \text { - } 1992 .\end{array}$ & $\begin{array}{l}\text { País/região: } \\
\text { Holanda/ } \\
\text { Europa. } \\
\text { Setor(es): } \\
\text { Indústria de } \\
\text { transformação. }\end{array}$ & $\begin{array}{l}\text { Variáveis dependentes: regimes } \\
\text { tecnológicos segundo Schumpeter } \\
\text { (Schumpeter Mark I; Schumpeter Mark } \\
\text { II). } \\
\text { Variáveis explanatórias: diversas } \\
\text { relacionadas às propriedades estruturais } \\
\text { e dinâmicas dos setores. }\end{array}$ & $\begin{array}{l}\text { Estatística } \\
\text { descritiva } \\
\text { Testes T-test e } \\
\text { F-test }\end{array}$ \\
\hline AP2 & $\begin{array}{l}\text { Hurmelinna et al. } \\
(2007)\end{array}$ & $\begin{array}{l}\text { Determinar o papel, a } \\
\text { disponibilidade, força e eficiência de } \\
\text { mecanismos de apropriabilidade } \\
\text { entre empresas de setores } \\
\text { selecionados da indústria de } \\
\text { transformação. }\end{array}$ & $\begin{array}{l}\text { Fonte: Pesquisa survey junto às } \\
\text { empresas da amostra } \\
\text { Amostra: } 229 \text { empresas com pelo } \\
\text { menos } 50 \text { empregados. }\end{array}$ & $\begin{array}{l}\text { País/região: } \\
\text { Finlândia/ } \\
\text { Europa. } \\
\text { Setor(es): } \\
\text { Selecionados da } \\
\text { indústria de } \\
\text { transformação. }\end{array}$ & $\begin{array}{l}\text { Variáveis dependentes: uso de } \\
\text { mecanismo formais de proteção; uso } \\
\text { técnico e tácito do conhecimento; tempo } \\
\text { de liderança frente à concorrência; } \\
\text { mecanismos de gestão de recursos } \\
\text { humanos (cláusulas contratuais de } \\
\text { trabalho, p.ex.). } \\
\text { Variáveis explanatórias e de controle: } \\
\text { força de mecanismos técnicos; força da } \\
\text { legislação trabalhista; força dos DPI; } \\
\text { força de contratos; força do tempo de } \\
\text { liderançaa; força do conhecimento tácito/ } \\
\text { força da gestão de recursos humanos; } \\
\text { Variáveis de moderação: objetivos de } \\
\text { inovação de longo prazo; objetivos de } \\
\text { inovação de curto prazo; barreiras para } \\
\text { competição. }\end{array}$ & $\begin{array}{l}\text { Estatística } \\
\text { descritiva } \\
\text { Teste de } \\
\text { hipóteses } \\
\text { Regressão } \\
\text { linear } \\
\text { hierárquica }\end{array}$ \\
\hline AP3 & $\begin{array}{l}\text { Hurmelinna- } \\
\text { Laukkanen et al. } \\
\text { (2008) }\end{array}$ & $\begin{array}{l}\text { Examinar as relações entre regimes } \\
\text { de apropriabilidade e inovações } \\
\text { radicais e incrementais }\end{array}$ & $\begin{array}{l}\text { Fonte: Pesquisa survey junto às } \\
\text { empresas selecionadas. } \\
\text { Amostra: } 299 \text { empresas com pelo } \\
\text { menos } 50 \text { empregados. }\end{array}$ & $\begin{array}{l}\text { País/região: } \\
\text { Finlândia/ } \\
\text { Europa. } \\
\text { Setor(es): } \\
\text { Selecionados da } \\
\text { indústria de } \\
\text { transformação. }\end{array}$ & $\begin{array}{l}\text { Variável dependente: desempenho } \\
\text { inovador. } \\
\text { Variáveis explanatórias: dinamismo } \\
\text { ambiental (setorial); intensidade de } \\
\text { esforços de P\&D; tamanho da empresa; } \\
\text { força do regime de apropriabilidade. } \\
\text { Variáveis de controle: empresas com } \\
\text { inovações radicais; empresas com } \\
\text { inovações incrementais. }\end{array}$ & $\begin{array}{l}\text { Estatística } \\
\text { descritiva } \\
\text { Teste de } \\
\text { hipóteses } \\
\text { Regressão } \\
\text { linear } \\
\text { hierárquica }\end{array}$ \\
\hline AP4 & $\begin{array}{l}\text { Hurmelinna- } \\
\text { Laukkanen (2009) }\end{array}$ & $\begin{array}{l}\text { Analisar a disponibilidade, força e } \\
\text { eficiência de mecanismos de } \\
\text { apropriabilidade para proteção de } \\
\text { investimentos na criação de } \\
\text { conhecimento. }\end{array}$ & $\begin{array}{l}\text { Fonte: coleta de dados junto a } \\
\text { empresas de Tecnologia de } \\
\text { informação e comunicação (TIC), } \\
\text { de diferentes tamanhos. } \\
\text { Foco: } 5 \text { empresas. }\end{array}$ & $\begin{array}{l}\text { País/região: } \\
\text { EUA/ América do } \\
\text { Norte. } \\
\text { Setor(es): } \\
\text { Tecnologia de } \\
\text { informação e } \\
\text { comunicação } \\
\text { (TIC). }\end{array}$ & $\begin{array}{l}\text { Variável dependente: proteção de } \\
\text { investimentos na criação de } \\
\text { conhecimento. } \\
\text { Variáveis explanatórias: disponibilidade, } \\
\text { força e eficiência de mecanismos de } \\
\text { apropriabilidade. }\end{array}$ & $\begin{array}{l}\text { Estudo de caso } \\
\text { Entrevistas } \\
\text { Estatística } \\
\text { descritiva }\end{array}$ \\
\hline
\end{tabular}


Quadro 2.1 - Quadro-síntese dos estudos empíricos sobre os temas centrais da pesquisa: cooperação interorganizacional em projetos de inovação e apropriação de valor pela criação de inovações (cont.)

\begin{tabular}{|c|c|c|c|c|c|c|}
\hline Ref. & Autores & Objetivo do estudo empírico & Fonte de dados/amostra & \begin{tabular}{|l|}
$\begin{array}{l}\text { País ou região/ } \\
\text { setores abordados }\end{array}$ \\
\end{tabular} & Variáveis & $\begin{array}{l}\text { Métodos de } \\
\text { análise adotados }\end{array}$ \\
\hline AP5 & Olander et al. (2014) & $\begin{array}{l}\text { Examinar como o uso de diferentes } \\
\text { mecanismos de proteção (formais e } \\
\text { informais) se relacionam com a } \\
\text { captação e criação de valor; e se } \\
\text { essas relações são afetadas pelo } \\
\text { objetivo estratégico de reduzir a } \\
\text { imitação de concorrentes ou } \\
\text { melhorar o compartilhamento de } \\
\text { conhecimento seguro para os } \\
\text { parceiros. }\end{array}$ & $\begin{array}{l}\text { Fonte: Pesquisa survey junto às } \\
\text { empresas da amostra no período } \\
2008-2009 . \\
\text { Amostra: } 209 \text { empresas que } \\
\text { cooperam e compartilham } \\
\text { conhecimento com parceiros em } \\
\text { projetos de inovação. }\end{array}$ & \begin{tabular}{|l} 
País/região: \\
Finlândia/ \\
Europa. \\
Setor(es): não \\
identificados.
\end{tabular} & $\begin{array}{l}\text { Variáveis dependentes: captura de valor; } \\
\text { criação de valor. } \\
\text { Variáveis explanatórias: uso de direitos } \\
\text { de propriedade intelectual (DPI); } \\
\text { contratos; segredo industrial; e natureza } \\
\text { tácita do conhecimento como } \\
\text { mecanismos de apropriabilidade. } \\
\text { Variáveis de moderação: objetivo de } \\
\text { prevenção da imitação; objetivo de } \\
\text { compartilhamento seguro de } \\
\text { conhecimento. }\end{array}$ & $\begin{array}{l}\text { Estatística } \\
\text { descritiva } \\
\text { Teste de } \\
\text { hipóteses } \\
\text { Análise } \\
\text { discriminante }\end{array}$ \\
\hline AP6 & Seo et al. (2017) & $\begin{array}{l}\text { Examinar a relação entre } \\
\text { cooperação em P\&D e geração de } \\
\text { inovaç̃̃es inesperadas (não- } \\
\text { planejadas); e os efeitos das } \\
\text { condições setoriais de } \\
\text { apropriabilidade e de intensidade } \\
\text { tecnológica na geração de } \\
\text { inovações inesperadas no contexto } \\
\text { da cooperação interorganizacional } \\
\text { em projetos de P\&D. }\end{array}$ & $\begin{array}{l}\text { Fonte: } 2012 \text { Korean Innovation } \\
\text { Survey (KIS): Manufacturing } \\
\text { industry' } \\
\text { Amostra: Inicialmente } 4.086 \\
\text { empresas da indústria de } \\
\text { transformação. Após aplicação } \\
\text { dos critérios de pesquisa: } 986 \\
\text { empresas. }\end{array}$ & $\begin{array}{l}\text { País/região: } \\
\text { Coreia/ } \\
\text { Ásia. } \\
\text { Setor(es): } \\
\text { Indústria de } \\
\text { transformação. }\end{array}$ & $\begin{array}{l}\text { Variáveis dependentes: geração de } \\
\text { inovações de produto não-planejadas; } \\
\text { geração de inovações de processo não- } \\
\text { planejadas. } \\
\text { Variáveis explanatórias: cooperação } \\
\text { interorganizacional (\# diferentes } \\
\text { parceiros); tamanho da empresa; } \\
\text { percentual de investimento em P\&D. } \\
\text { Variáveis categóricas: classificação das } \\
\text { atividades econômicas; obstáculos à } \\
\text { inovação. } \\
\text { parceiros) } \\
\text { Variáveis de controle: faixas de pessoal } \\
\text { alocado; intensidade de P\&D (\%); } \\
\text { intensidade de exportações (\%); } \\
\text { estoque de patentes; estoque de } \\
\text { marcas; valor da propriedade } \\
\text { intelectual; experiência legal; controle } \\
\text { da indústria. }\end{array}$ & $\begin{array}{l}\text { Estatística } \\
\text { descritiva } \\
\text { Regressão } \\
\text { logística }\end{array}$ \\
\hline AP7 & Zobel et al. (2017) & $\begin{array}{l}\text { Analisar em que medida a } \\
\text { capacidade inovativa e a adoção de } \\
\text { estratégias de inovação aberta por } \\
\text { empresas inovadoras influenciam o } \\
\text { uso de mecanismos formais e } \\
\text { informais para proteção de novos } \\
\text { conhecimentos. }\end{array}$ & $\begin{array}{l}\text { Fonte: } 1998 \text { and } 2000 \text { Dutch } \\
\text { Community Innovation Surveys } \\
\text { (CIS). } \\
\text { Amostra: } 1.133 \text { empresas } \\
\text { inovadoras observadas em ambas } \\
\text { pesquisas nacionais (1998 e 2000) } \\
\text { operando em diversos setores da } \\
\text { indústria de transformação. }\end{array}$ & $\begin{array}{l}\text { País/região: } \\
\text { Holanda/ } \\
\text { Europa. } \\
\text { Setor(es): } \\
\text { Indústria de } \\
\text { transformação. }\end{array}$ & $\begin{array}{l}\text { Variáveis dependentes: uso de } \\
\text { mecanismos formais de apropriação de } \\
\text { valor; uso de mecanismos informais de } \\
\text { apropriação de valor. } \\
\text { Variáveis explanatórias: amplitude do } \\
\text { uso de fontes externas de conhecimento; } \\
\text { importância atribuída a fontes externas } \\
\text { nas atividades inovativas (\# diferentes } \\
\text { fontes externas de conhecimento). } \\
\text { Variáveis de controle: intensidade de } \\
\text { esforços em P\&D; tamanho da empresa; } \\
\text { empresa pertencendo a um grupo } \\
\text { empresarial maior. } \\
\text { Variáveis categóricas: classificação de } \\
\text { atividades econômicas (dois dígitos). }\end{array}$ & $\begin{array}{l}\text { Método } \\
\text { generalizado } \\
\text { dos momentos } \\
\text { (MGM) }\end{array}$ \\
\hline
\end{tabular}


Para facilitar a identificação das lacunas de pesquisa, os estudos empíricos foram classificados pela ênfase temática, a saber: (i) 19 estudos sobre cooperação interorganizacional em projetos de inovação (CO1 a CO19); e (ii) 7 sobre regimes de apropriabilidade e apropriação de valor pela criação de inovações (AP1 a AP7).

Analisando-se os estudos empíricos apresentados no quadro 2.1, pode-se constatar que muitos já abordaram os temas centrais dessa pesquisa, separadamente ou correlacionando-os. A maioria foi desenvolvida em países europeus (Alemanha; Bélgica; Espanha; Finlândia, França; Holanda; Itália; e Reino Unido;); dois na Ásia (Coreia e China); um no Brasil e outro nos EUA.

Do total de 26 estudos, 19 referem-se a questões relacionadas à cooperação interorganizacional, sendo as variáveis dependentes mais estudadas a importância atribuída aos parceiros em projetos de $\mathrm{P} \& \mathrm{D}$ (por tipo de parceiro); e riscos na cooperação em P\&D (imitação, por exemplo). Cabe ressaltar a diversidade de variáveis explanatórias e de controle que foram definidas em função das questões norteadoras de cada estudo e das características das diferentes fontes de dados. Os principais métodos estatísticos para análise foram regressão logística (modelos logit) e análise de regressão hierárquica, além de estatística descritiva.

Já os sete estudos empíricos sobre regimes de apropriabilidade e apropriação de valor focalizaram variáveis dependentes como a disponibilidade e força de mecanismos formais e informais de proteção, bem como a apropriação de valor pelas inovações geradas em cada regime de apropriabilidade. As variáveis explanatórias e de controle também variaram muito nesses estudos, pelas mesmas razões já mencionadas na análise do primeiro agrupamento (CO1 a CO19). Os métodos mais adotados nesses estudos foram análise de regressão hierárquica, teste de hipóteses e estatística descritiva.

Constatou-se ainda que, dentre os 26 estudos empíricos, poucos já abordaram os dois temas centrais, correlacionando-os de alguma forma (HurmelinnaLaukkanen, 2011; Henttonen, Hurmelinna-Laukkanen e Ritala, 2016; Veer, Lorenz e Blind, 2016; Pereira, 2017; e Lorenz e Veer, 2019). No entanto, como mencionado por Pereira (2017, p.81):

"O campo para pesquisas que busquem analisar a importância da cooperação com diferentes parceiros para os diferentes resultados de inovação encontra-se em aberto para novas constatações". 
Não obstante a importância dos resultados alcançados até o momento para o avanço do conhecimento na temática em foco, concluiu-se que estudos anteriores não analisaram a influência de diferentes tipos de parceiros em arranjos cooperativos formados por empresas da indústria de transformação na apropriação de valor de suas inovações, considerando-se condições ambientais distintas e diferentes características internas.

Na próxima seção, propõe-se um modelo conceitual focalizando esta questão de pesquisa e formulam-se as hipóteses de pesquisa a serem confirmadas mediante estudo empírico desenvolvido com base em dados da Pintec 2014 (capítulo 4).

\section{8.}

\section{Proposta de modelo conceitual da pesquisa}

A revisão da literatura que integra este capítulo apontou para a relevância dos temas cooperação interorganizacional para inovação e apropriação de valor pelas inovações geradas pelas empresas em arranjos cooperativos para inovar. Pretendese com a presente pesquisa contribuir para a análise da influência da cooperação interorganizacional na apropriação de valor das inovações geradas pelas empresas da indústria de transformação, conforme proposto esquematicamente na figura 2.1.

De acordo com esta proposta do modelo conceitual, consideram-se os principais tipos de parceiros escolhidos pelas empresas em arranjos cooperativos para inovar, a saber:

- Clientes e consumidores;

- Fornecedores;

- Concorrentes;

- Outra empresa do grupo;

- Empresas de consultoria;

- Universidades ou institutos de pesquisa;

- Centros de capacitação profissional e assistência técnica;

- Instituições de ensaios e certificações.

Com base nos resultados de estudos empíricos selecionados (Bayona et al., 2001; Tether, 2002; Sáez et al., 2002; Bönte e Keilbach, 2005; Silva et al., 2005; Arranz e Arroyabe, 2008; Pires, 2013; e Moura, 2016), parte-se do pressuposto que a cooperação interoganizazional em projetos de PD\&I influencia a criação de 
inovações pelas empresas e a apropriação de valor pelas inovações geradas. Buscase na presente pesquisa investigar a influência dos relacionamentos entre as empresas da indústria de transformação no Brasil e seus parceiros em projetos de PD\&I na apropriação de valor decorrente das inovações geradas em arranjos cooperativos, expressa por impactos mercadológicos; operacionais (na produção); ambientais; sociais; e regulatórios.

A figura 2.1 representa esquematicamente o modelo conceitual proposto, a partir do qual selecionam-se as variáveis explanatórias e dependentes e formulamse as hipóteses de pesquisa, como será retomado no capítulo 4 (seção 4.2 'Hipóteses de pesquisa').

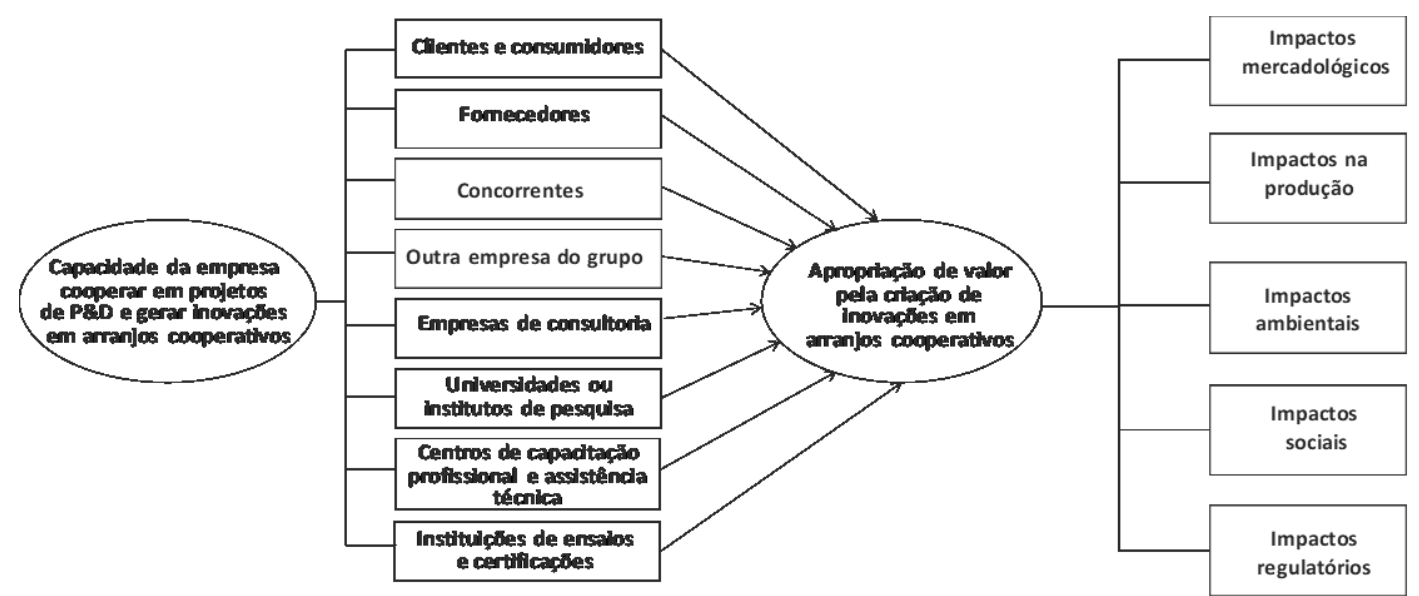

Figura 2.1 - Modelo conceitual da influência de diferentes parceiros em arranjos cooperativos sobre a apropriação de valor das inovações geradas pelas empresas da indústria de transformação no Brasil

Fonte: Elaboração própria.

Cabe ainda destacar que o modelo conceitual proposto associa a influência dos relacionamentos externos em projetos de PD\&I a cada uma das dimensões de impactos das inovações geradas em arranjos cooperativos, a saber: (i) mercadológicos; (ii) na produção; (iii) ambientais; (iv) sociais; e (v) regulatórios.

Investigar as correlações entre os tipos de relacionamentos em arranjos cooperativos e a materialização de ganhos com inovações geradas pelas empresas da indústria de transformação no Brasil vem preencher a lacuna identificada durante a revisão bibliográfica desta pesquisa. Como já abordado, os estudos anteriores sintetizados no quadro 2.5 não consideraram a força do regime de apropriabilidade e o nível de intensidade tecnológica setorial (OCDE, 2011) como fatores que podem condicionar a escolha de parceiros para o sucesso de arranjos de cooperação interorganizacional em projetos de PD\&I. 
$\mathrm{Na}$ esfera governamental, os resultados gerados (por intensidade tecnológica setorial) serão relevantes para a formulação de políticas públicas de inovação mais consistentes e bem estruturadas para os setores da indústria de transformação no Brasil.

No contexto das instituições de C\&T (ICT), acredita-se que os resultados desta pesquisa possam revelar novas oportunidades para estudos futuros sobre a temática em foco. 


\section{3 \\ Principais características da inovação na indústria de transformação no Brasil}

Neste capítulo, apresenta-se inicialmente um panorama geral da indústria brasileira de transformação no Brasil, destacando-se os desafios atuais frente à desindustrialização que vem acontecendo desde meados dos anos 80 e as características inovativas desta indústria. A partir dos indicadores da Pintec 2014, busca-se caracterizar as empresas que geraram inovações no período 2012-2014 (inovações de produto e/ou processo ou com projetos de inovação). Na sequência, detalham-se as atividades inovativas realizadas por essas empresas; seu envolvimento em arranjos cooperativos com outras organizações na perspectiva de inovar e os impactos das inovações que geram em diferentes dimensões, a saber: mercado; produção; ambiental; social; e regulatória.

\section{1.}

\section{Panorama geral da indústria brasileira de transformação no Brasil}

Desde meados da década de 1980, percebe-se que a indústria de transformação brasileira interrompeu a longa trajetória de expansão de sua participação no Produto Interno Bruto (PIB) e na ocupação total do país.

Dos anos 1950 até 1985 transcorreu o primeiro período, caracterizado por um intenso processo de crescimento, diversificação e consolidação da estrutura industrial brasileira. Foi nesse período que a participação da indústria de transformação no PIB quase duplicou, saltando dos 11,4\% em 1952 para 21,8\% em 1985 (Fiesp, 2019).

Nota-se que o processo de industrialização brasileiro avançou bastante durante três décadas, dos anos 1950 até os anos 1980. A parcela da indústria de transformação no valor adicionado (VA) total elevou-se de $16 \%$ na década de 1950 para aproximadamente $27 \%$ do VA no início da década de 1980 . Neste período a industrialização brasileira alcançou o seu auge. O país fabricava os produtos de praticamente todos os setores industriais existentes nos países avançados, 
consolidava o parque produtivo da indústria 2.0 e instalava alguns segmentos que ficariam conhecidos como indústria 3.0 (IEDI, 2019a). Cabe destacar que o crescimento econômico do Brasil foi elevado e teve o setor industrial na liderança durante as três décadas de industrialização.

No entanto, já no segundo período, a partir de 1986, observa-se uma significativa perda de participação da indústria na produção agregada do país, configurando-se o processo de desindustrialização. De acordo com dados do IBGE e estimativas $\mathrm{d}=\mathrm{a}$ Fiesp, a participação da indústria de transformação no PIB declinou quase 10 pontos percentuais ao longo do último período, atingindo, em 2018, a marca dos 11,3\% (Fiesp, 2019).

A figura 3.1 mostra a evolução da participação da indústria de transformação no PIB no período de 1947 a 2018.

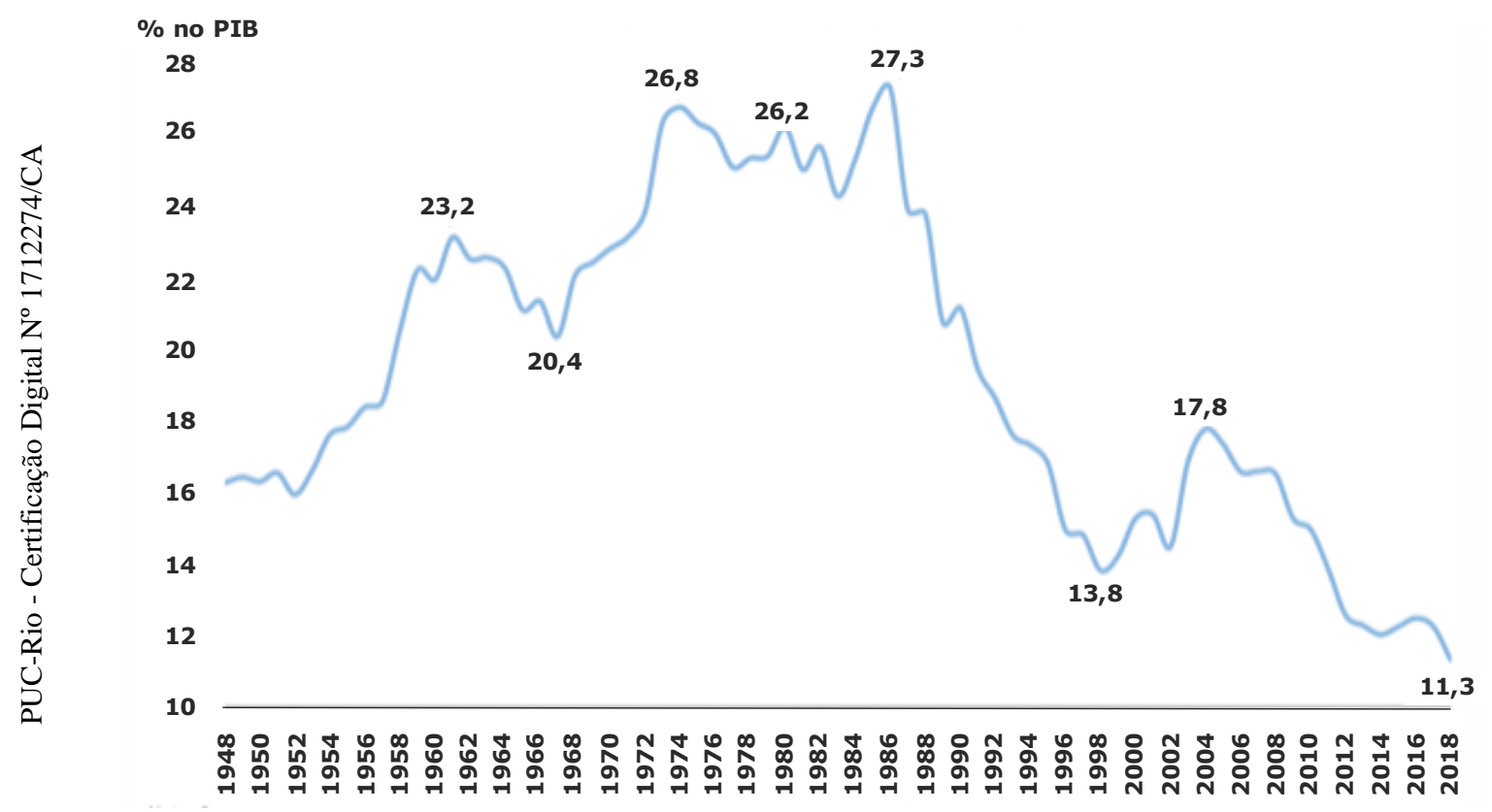

Figura 3.1 - Participação da indústria de transformação no PIB: Brasil- 1948 - 2018 Fonte: Morceiro (2019) apud IEDI (2019a).

De acordo com o estudo do IEDI (2019b), a desindustrialização brasileira já foi tema de diversos estudos de diferentes orientações teóricas (IEDI, 2019a; Morceiro, 2019; Silva, 2014; Oreiro e Feijó, 2010; dentre outros). Não obstante seus resultados, algumas questões continuam sendo objeto de debate, a saber:

- Nas últimas décadas, todos os setores da indústria de transformação perderam participação no PIB? Ou a diminuição foi concentrada setorialmente?

- Há algum setor que não teve desindustrialização? Os setores mais 
desindustrializados são de alta ou baixa intensidade tecnológica?

- A taxa de inovação apresenta variação dentre os diversos setores da indústria de transformação, em função de diversos graus de oportunidade tecnológica entre setores; e da capacidade inovativa das empresas?

Essas questões serão abordadas ao longo deste capítulo, como pano de fundo caracterizar os setores da indústria de transformação que mais geraram inovações no período 2012-2014 (inovações de produto e/ou processo ou com projetos de inovação). Complementando-se esse quadro mais geral, detalham-se as atividades inovativas realizadas por setor; o envolvimento das empresas inovadoras em arranjos cooperativos com outras organizações em projetos de inovação; e os impactos das inovações. As duas últimas questões serão objeto do estudo empírico desenvolvido durante esta pesquisa, com base em microdados da Pintec 2014.

O movimento de retrocesso relativo é concentrado setorialmente. Metade dos setores da indústria de transformação (alimentos, bebidas; fumo; têxteis; vestuário; couro e calçados; móveis e madeira; metalurgia e produtos de metal; química e petroquímica; máquinas e equipamentos) foram responsáveis por mais de $4 / 5$ da perda de participação dessa indústria no PIB entre 1970 e 2016 (IEDI, 2019b).

Os setores de menor intensidade tecnológica (vestuário; couro e calçados; têxteis; minerais não metálicos; móveis e produtos de madeira) seguiram o padrão internacional e perderam participação no PIB à medida que a renda per capita do país aumentou.

A participação no PIB de setores de maior intensidade tecnológica (máquinas e equipamentos; química e petroquímica; indústria automobilística; e outros equipamentos de transporte) começou a declinar prematuramente. Em conjunto, os setores de maior intensidade tecnológica perderam 40\% de peso no PIB desde 1980. Isso é muito crítico e desfavorável ao desenvolvimento do país, considerando-se o dinamismo tecnológico desses setores em nível mundial.

Alguns setores de alta e média-alta intensidade tecnológica (como a fabricação de produtos farmoquímicos e farmacêuticos; materiais elétricos; e informática e eletroeletrônicos) não regrediram, mas também não ampliaram sua participação na economia como ocorreu em outros países, que passaram por um processo de desindustrialização relativa (IEDI, 2019b).

O setor de informática e eletrônicos - com um papel central na quarta revolução industrial em curso (indústria 4.0) - tem uma participação pequena na 
estrutura industrial (representa só $0,5 \%$ do PIB) e cresce muito pouco. A título de comparação, nos Estados Unidos, esse setor responde por um percentual do PIB 3,5 vezes maior do que no Brasil. Segundo o estudo do IEDI, prevê-se que o país enfrentará grandes dificuldades para acompanhar as transformações da era digital.

De acordo com dados das Contas Nacionais do IBGE, em 2017, a indústria de transformação respondeu por $11,8 \%$ do PIB. Neste mesmo ano, o setor de serviços representou $60,6 \%$ do PIB, o comércio $12,7 \%$, a agropecuária 5,3\% e a construção civil 5,2\%. A indústria total, constituída pela indústria de transformação, pela indústria extrativa mineral e pelos serviços industriais de utilidade pública representou 16,2\% do PIB (Fiesp, 2019, p. 9).

A figura 3.2, a seguir, mostra a distribuição do PIB por setores da economia brasileira em 2017 , sendo que a indústria de transformação representou $11,8 \%$ do PIB naquele ano.

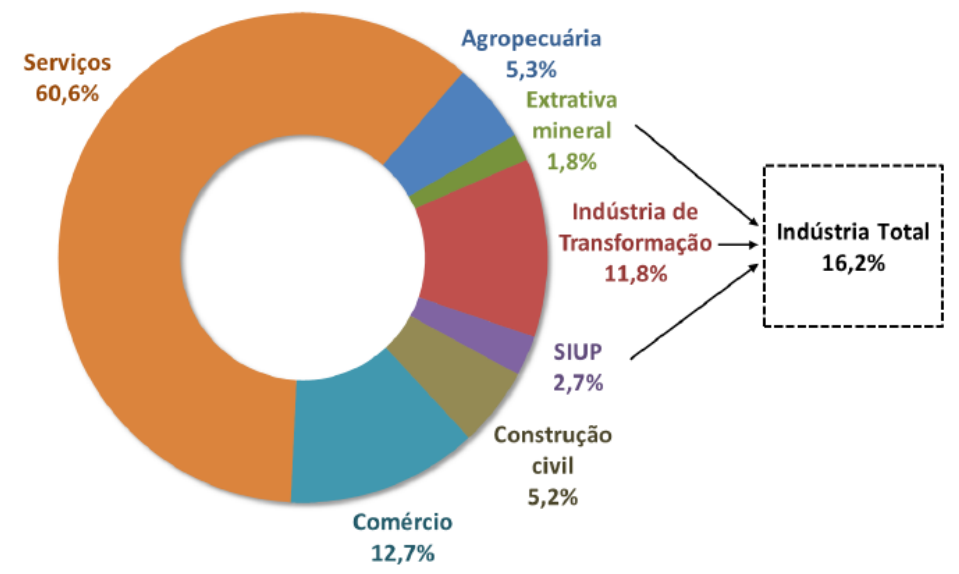

Figura 3.2 - Distribuição do PIB por setores da economia: Brasil - 2017 Fonte: Fiesp (2019, p. 9).

A tabela 3.1 mostra a distribuição do valor adicionado entre os setores da indústria de transformação e sua participação no PIB (Fiesp, 2019).

Para o cálculo do valor adicionado por setor, a Fiesp utilizou o valor adicionado do total da indústria de transformação segundo as Contas Nacionais e a distribuição do valor adicionado entre os setores industriais da PIA.

O valor adicionado da indústria de transformação em 2016 era de R\$ 675,8 bilhões. Os setores com maior participação neste valor e, consequentemente, no PIB em 2016 foram: produtos alimentícios (19,1\% do valor adicionado da indústria de 
transformação); coque, derivados do petróleo e biocombustíveis (13,6\%); produtos químicos $(9,2 \%)$; metalurgia (5,3\%) e veículos automotores $(5,3 \%)$.

Tabela 3.1 - Valor adicionado da indústria de transformação por setor: Brasil - 2016

\begin{tabular}{|c|c|c|c|}
\hline Setor & $\begin{array}{l}\text { Valor } \\
\text { adicionado } \\
\text { (R\$ } \\
\text { milhões) } \\
\end{array}$ & $\begin{array}{l}\text { Participação do VA } \\
\text { do setor na } \\
\text { indústria de } \\
\text { transformação (\%) }\end{array}$ & $\begin{array}{c}\text { Participação do } \\
\text { VA no PIB } \\
(\%)\end{array}$ \\
\hline Indústria de transformação & 675.816 & 100 & 12,5 \\
\hline Fabricação de produtos alimentícios & 128.979 & 19,1 & 2,4 \\
\hline $\begin{array}{l}\text { Fabricação de coque, de produtos derivados do } \\
\text { petróleo e de combustíveis }\end{array}$ & 92.243 & 13,6 & 1,7 \\
\hline Fabricação de produtos químicos & 62.206 & 9,2 & 1,1 \\
\hline Metalurgia & 35.890 & 5,3 & 0,7 \\
\hline $\begin{array}{l}\text { Fabricação de veículos automotores, reboques } \\
\text { e carrocerias }\end{array}$ & 35.738 & 5.3 & 0,7 \\
\hline Fabricação de máquinas e equipamentos & 32.478 & 4,8 & 0,6 \\
\hline $\begin{array}{l}\text { Fabricação de celulose, papel e produtos de } \\
\text { papel }\end{array}$ & 28.120 & 4.2 & 0,5 \\
\hline Fabricação de artigos de borracha e plástico & 27.140 & 4,0 & 0,5 \\
\hline Fabricação de bebidas & 24.486 & 3,6 & 0,5 \\
\hline Fabricação de produtos de metal & 23.787 & 3,5 & 0,4 \\
\hline $\begin{array}{l}\text { Fabricação de produtos de minerais não- } \\
\text { metálicos }\end{array}$ & 23.657 & 3,5 & 0,4 \\
\hline $\begin{array}{l}\text { Fabricação de máquinas, aparelhos e materiais } \\
\text { elétricos }\end{array}$ & 21.430 & 3,2 & 0,4 \\
\hline $\begin{array}{l}\text { Fabricação de produtos farmoquímicos e } \\
\text { farmacêuticos }\end{array}$ & 19.783 & 2,9 & 0,4 \\
\hline Confecção de artigos do vestuário e acessórios & 18.050 & 2,7 & 0,3 \\
\hline $\begin{array}{l}\text { Fabricação de equipamentos de informática, } \\
\text { produtos eletrônicos e ópticos }\end{array}$ & 15.823 & 2,3 & 0,3 \\
\hline $\begin{array}{l}\text { Preparação de couros e fabricação de artefatos } \\
\text { de couro, artigos de viagem e calçados }\end{array}$ & 12.782 & 1,9 & 0,2 \\
\hline $\begin{array}{l}\text { Manutenção, reparação e instalação de } \\
\text { máquinas e equipamentos }\end{array}$ & 12.576 & 1,9 & 0,2 \\
\hline Fabricação de produtos têxteis & 11.747 & 1,7 & 0,2 \\
\hline $\begin{array}{l}\text { Fabricação de outros equipamentos de } \\
\text { transporte }\end{array}$ & 11.076 & 1,6 & 0,2 \\
\hline Fabricação de produtos diversos & 9.953 & 1,5 & 0,2 \\
\hline Fabricação de móveis & 9.404 & 1,4 & 0,2 \\
\hline Fabricação de produtos de madeira & 8.352 & 1,2 & 0,2 \\
\hline Impressão e reprodução de gravações & 6.819 & 1,0 & 0,1 \\
\hline Fabricação de produtos do fumo & 3.297 & 0,5 & 0,1 \\
\hline
\end{tabular}

Fonte: Fiesp (2019, p. 11).

De acordo com o estudo da Fiesp (2019), a análise dos dados da RAIS-MTE contidos na tabela 3.2 permite constatar que, em 2017, entre os setores da indústria de transformação, aquele que mais tinha estabelecimentos era o de confecções de artigos do vestuário e acessórios (14,9\%), seguido pelo alimentício (14,5\%) e, em terceiro lugar, pelo setor de produtos de metal $(11,6 \%)$. 
Tabela 3.2 - Estabelecimentos da indústria de transformação por setor: Brasil - 2017

\begin{tabular}{|c|c|c|}
\hline Setor & $\begin{array}{l}\text { Número de } \\
\text { estabelecimentos } \\
\text { (n) }\end{array}$ & $\begin{array}{l}\text { Participação } \\
\text { (\%) }\end{array}$ \\
\hline Indústria de transformação & 330.801 & 100 \\
\hline Confecção de artigos do vestuário e acessórios & 49,133 & 14,9 \\
\hline Fabricação de produtos alimentícios & 47.811 & 14,5 \\
\hline $\begin{array}{l}\text { Fabricação de produtos de metal, exceto máquinas e } \\
\text { equipamentos }\end{array}$ & 38.479 & 11,6 \\
\hline Fabricação de produtos de minerais não-metálicos & 26.945 & 8,1 \\
\hline Manutenção e instalação de máquinas e equipamentos & 22.215 & 6,7 \\
\hline Fabricação de móveis & 21.157 & 6,4 \\
\hline Fabricação de produtos de madeira & 13.811 & 4,2 \\
\hline Fabricação de produtos de borracha e material plástico & 13.736 & 4,2 \\
\hline Fabricação de máquinas e equipamentos & 13.695 & 4,1 \\
\hline Fabricação de produtos diversos & 13.341 & 4,0 \\
\hline Impressão e reprodução de gravações & 13.309 & 4,0 \\
\hline $\begin{array}{l}\text { Fabricação de artefatos de couro, artigos de viagem e } \\
\text { calçados }\end{array}$ & 10.958 & 3,3 \\
\hline Fabricação de produtos têxteis & 10.153 & 3,1 \\
\hline Fabricação de produtos químicos & 8.990 & 2,7 \\
\hline $\begin{array}{l}\text { Fabricação de veículos automotores, carrocerias e } \\
\text { autopeças }\end{array}$ & 6.120 & 1,9 \\
\hline Fabricação de máquinas, aparelhos e materiais elétricos & 4.475 & 1,4 \\
\hline Fabricação de celulose, papel e produtos de papel & 4.265 & 1,3 \\
\hline Metalurgia & 3.584 & 1,1 \\
\hline $\begin{array}{l}\text { Fabricação de equipamentos de informática, produtos } \\
\text { eletrônicos e ópticos }\end{array}$ & 3.246 & 1,0 \\
\hline Fabricação de bebidas & 2.656 & 0,8 \\
\hline $\begin{array}{l}\text { Fabricação de outros equipamentos de transporte, exceto } \\
\text { veículos automotores }\end{array}$ & 1.164 & 0,4 \\
\hline Fabricação de produtos farmoquímicos e farmacêuticos & 808 & 0,2 \\
\hline $\begin{array}{l}\begin{array}{l}\text { Fabricação de coque, derivados de petróleo e } \\
\text { biocombustíveis }\end{array} \\
\end{array}$ & 547 & 0,2 \\
\hline Fabricação de produtos do fumo & 203 & 0,1 \\
\hline
\end{tabular}

Fonte: Fiesp (2019, p. 18).

\section{2.}

\section{Inovação na indústria de transformação}

A tabela 3.3, a seguir, fornece um quadro geral das empresas da indústria de transformação que implementaram inovações de produto e/ou processo e que tiveram projetos incompletos e/ou abandonados no período 2012-2014.

Com base nos dados da tabela 3.3, calculou-se a participação percentual das empresas da indústria de transformação que implementaram efetivamente inovações em relação ao total de firmas desta indústria. Constatou-se que essa taxa foi relativamente baixa para a indústria como um todo (36\%), sendo que para a maioria das atividades a taxa ficou abaixo de 50\% (figura 3.3). 
Tabela 3.3 - Empresas da indústria de transformação que implementaram inovação de produto e/ou processo ou com projetos: Brasil - 2014

\begin{tabular}{|c|c|c|c|}
\hline \multirow[b]{2}{*}{ Atividades } & \multirow[b]{2}{*}{$\begin{array}{l}\text { Total de } \\
\text { empresas }\end{array}$} & \multicolumn{2}{|c|}{ Empresas que implementaram } \\
\hline & & $\begin{array}{l}\text { Inovação de } \\
\text { produto } \\
\text { elou processo }\end{array}$ & $\begin{array}{l}\text { Com projetos } \\
\text { incompletos ou } \\
\text { abandonados }\end{array}$ \\
\hline Indústria de transformação & 115.268 & 41.850 & 3.310 \\
\hline Fabricação de produtos alimentícios & 13.846 & 6.168 & 478 \\
\hline Fabricação de bebidas & 967 & 423 & 14 \\
\hline Fabricação de produtos do fumo & 68 & 24 & 5 \\
\hline Fabricação de produtos têxteis & 3.856 & 1.234 & 111 \\
\hline Confeç̧ão de artigos do vestuário e acessórios & 17.582 & 5.107 & 361 \\
\hline $\begin{array}{l}\text { Preparação de couros e fabricação de artefatos } \\
\text { de couro, artigos de viagem e calçados }\end{array}$ & 4.921 & 1.415 & 153 \\
\hline Fabricação de produtos de madeira & 5.235 & 1.325 & 193 \\
\hline $\begin{array}{l}\text { Fabricação de celulose, papel e produtos de } \\
\text { papel }\end{array}$ & 2.133 & 647 & 49 \\
\hline Impressão e reprodução de gravações & 3.037 & 839 & 93 \\
\hline $\begin{array}{l}\text { Fabricação de coque, de produtos derivados do } \\
\text { petróleo e de combustíveis }\end{array}$ & 295 & 125 & 8 \\
\hline Fabricação de produtos químicos & 3.632 & 1.802 & 40 \\
\hline $\begin{array}{l}\text { Fabricação de produtos farmoquímicos e } \\
\text { farmacêuticos }\end{array}$ & 406 & 212 & 52 \\
\hline Fabricação de artigos de borracha e plástico & 7.148 & 2.925 & 165 \\
\hline $\begin{array}{l}\text { Fabricação de produtos de minerais não- } \\
\text { metálicos }\end{array}$ & 10.982 & 4.229 & 204 \\
\hline Metalurgia & 1.776 & 669 & 133 \\
\hline Fabricação de produtos de metal & 11.935 & 3.513 & 603 \\
\hline $\begin{array}{l}\text { Fabricação de equipamentos de informática, } \\
\text { produtos eletrônicos e ópticos }\end{array}$ & 1.542 & 1.053 & 23 \\
\hline $\begin{array}{l}\text { Fabricação de máquinas, aparelhos e materiais } \\
\text { elétricos }\end{array}$ & 2.170 & 1.022 & 100 \\
\hline Fabricação de máquinas e equipamentos & 6.588 & 2.657 & 155 \\
\hline $\begin{array}{l}\text { Fabricação de veículos automotores, reboques } \\
\text { e carrocerias }\end{array}$ & 2.765 & 1.080 & 32 \\
\hline $\begin{array}{l}\text { Fabricação de outros equipamentos de } \\
\text { transporte }\end{array}$ & 598 & 227 & 6 \\
\hline Fabricação de móveis & 6.168 & 2.714 & 64 \\
\hline Fabricação de produtos diversos & 3.531 & 1.504 & 98 \\
\hline $\begin{array}{l}\text { Manutenção, reparação e instalação de } \\
\text { máquinas e equipamentos }\end{array}$ & 4.088 & 937 & 170 \\
\hline
\end{tabular}

Fonte: IBGE (2016). Extrato da Tabela 1.1.1 da Pintec 2014. Elaboração própria.

Como pode ser observado na figura 3.3, a seguir, a taxa de inovação apresenta variação dentre os diversos setores da indústria de transformação, considerando-se apenas o período 2012-2014. Há diferentes possíveis razões para tal variância, como condições setoriais (intensidade tecnológica, força do regime de apropriabilidade, dentre outras), os diversos graus de oportunidade tecnológica entre setores e capacidade inovativa das empresas. 


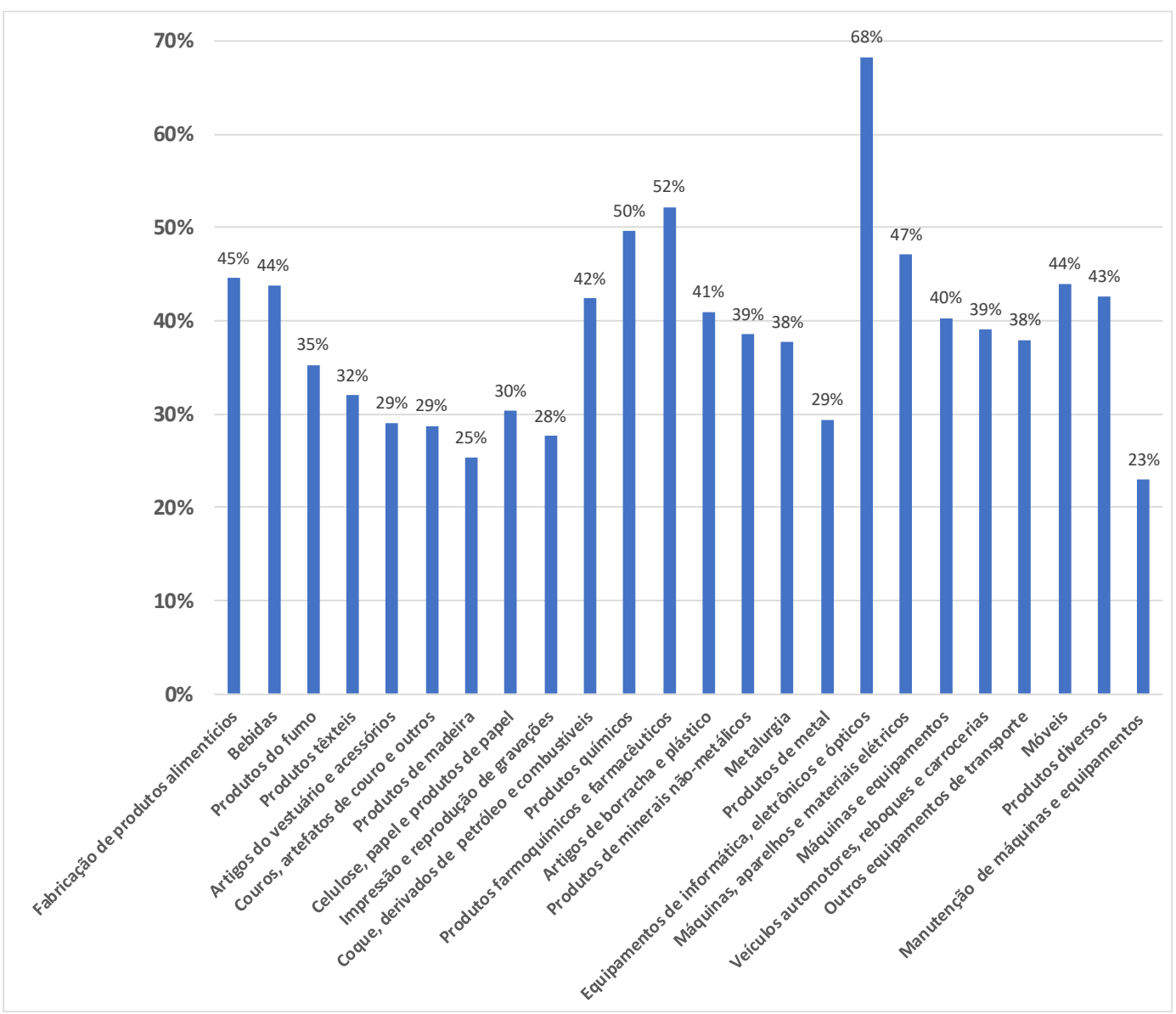

Figura 3.3 - Taxa de empresas que implementaram inovações, por atividade da indústria de transformação (\%): Brasil - 2014

Fonte: IBGE (2016). Tabela 1.1.1. Elaboração própria.

Destacam-se na figura 3.3 aqueles setores que alcançaram taxas iguais ou superiores a 50\%, a saber: (i) fabricação de equipamentos de informática, produtos eletrônicos e ópticos (68\%); (ii) fabricação de produtos farmoquímicos e farmacêuticos (52\%); e (iii) fabricação de produtos químicos $(50 \%)$.

Outra possível explicação pode ser encontrada para setores com ciclos de vida do produto menores, como o caso da fabricação de equipamentos de informática, produtos eletrônicos e ópticos (maior taxa de inovação, dentre todos os setores da indústria de transformação).

Embora essa situação não seja favorável em termos do potencial de crescimento setorial impulsionado por inovações, a questão mais crítica revelada pelos dados divulgados pela Pintec 2014 refere-se à baixa proporção dos dispêndios em P\&D interno em relação ao dispêndio total em atividades inovativas, considerando-se que esforços de P\&D interno contribuem de forma significativa para a formação de arranjos de cooperação interorganizacional voltados para a geração de novos produtos e processos que chegam ao mercado. (tabela 3.4) 
Tabela 3.4 - Dispêndios realizados em atividades internas de P\&D pelas empresas da indústria de transformação: Brasil - 2014

\begin{tabular}{|c|c|c|c|c|c|}
\hline \multirow[b]{3}{*}{ Atividades } & \multicolumn{4}{|c|}{$\begin{array}{c}\text { Dispêndios realizados pelas empresas } \\
\text { inovadoras nas atividades inovativas }-2014\end{array}$} & \multirow{3}{*}{$\begin{array}{c}\text { Dispêndios } \\
\text { para P\&D } \\
\text { interno (\%) }\end{array}$} \\
\hline & \multicolumn{2}{|c|}{ Total } & \multicolumn{2}{|c|}{ P\&D Interno } & \\
\hline & $\begin{array}{l}N^{\circ} \text { de } \\
\text { empresas }\end{array}$ & $\begin{array}{l}\text { Valor } \\
(1.000 R \$)\end{array}$ & $\begin{array}{l}N^{\circ} \text { de } \\
\text { empresas }\end{array}$ & $\begin{array}{l}\text { Valor } \\
(1.000 \mathrm{R} \$)\end{array}$ & \\
\hline Indústria de transformação & 33.573 & 55.891 .758 & 5.877 & 17.560 .176 & 31 \\
\hline Fabricação de produtos alimentícios & 4.841 & 7.106 .516 & 572 & 776.246 & 11 \\
\hline Fabricação de bebidas & 340 & 2.152 .772 & 81 & 62.540 & 3 \\
\hline Fabricação de produtos do fumo & 16 & 170.408 & 10 & 75.430 & 44 \\
\hline Fabricação de produtos têxteis & 1.108 & 761.050 & 78 & 59.212 & 8 \\
\hline $\begin{array}{l}\text { Confecção de artigos do vestuário e } \\
\text { acessórios }\end{array}$ & 3.867 & 805.552 & 79 & 105.549 & 13 \\
\hline $\begin{array}{l}\text { Preparação de couros e fabricação de } \\
\text { artefatos de couro, artigos de viagem e } \\
\text { calçados }\end{array}$ & 1.086 & 673.702 & 70 & 264.533 & 39 \\
\hline Fabricação de produtos de madeira & 1.138 & 630.051 & 34 & 48.121 & 8 \\
\hline $\begin{array}{l}\text { Fabricação de celulose, papel e produtos } \\
\text { de papel }\end{array}$ & 599 & 1.219 .031 & 60 & 275.760 & 23 \\
\hline Impressão e reprodução de gravações & 629 & 444.443 & 48 & 55.991 & 13 \\
\hline $\begin{array}{l}\text { Fabricação de coque, de produtos } \\
\text { derivados do petróleo e de combustíveis }\end{array}$ & 110 & 4.823 .909 & 31 & 2.665 .346 & 55 \\
\hline Fabricação de produtos químicos & 1.493 & 4.748 .945 & 957 & 1.966 .468 & 41 \\
\hline $\begin{array}{l}\text { Fabricação de produtos farmoquímicos e } \\
\text { farmacêuticos }\end{array}$ & 191 & 2.281 .624 & 113 & 1.228 .473 & 54 \\
\hline $\begin{array}{l}\text { Fabricação de artigos de borracha e } \\
\text { plástico }\end{array}$ & 2.337 & 2.086 .346 & 348 & 467.323 & 22 \\
\hline $\begin{array}{l}\text { Fabricação de produtos de minerais não- } \\
\text { metálicos }\end{array}$ & 3.434 & 2.369 .375 & 178 & 295.289 & 12 \\
\hline Metalurgia & 540 & 2.513 .146 & 104 & 558.020 & 22 \\
\hline Fabricação de produtos de metal & 2.751 & 2.092 .468 & 552 & 206.135 & 10 \\
\hline $\begin{array}{llr}\text { Fabricação } & \text { de equipamentos } & \text { de } \\
\text { informática, produtos eletrônicos } & \text { e } \\
\text { ópticos } & & \\
\end{array}$ & 847 & 2.795 .774 & 462 & 1.555 .772 & 56 \\
\hline $\begin{array}{l}\text { Fabricação de máquinas, aparelhos e } \\
\text { materiais elétricos }\end{array}$ & 845 & 2.179 .327 & 403 & 1.367 .967 & 63 \\
\hline Fabricação de máquinas e equipamentos & 2.258 & 2.835 .718 & 787 & 1.041 .178 & 37 \\
\hline $\begin{array}{l}\text { Fabricação de veículos automotores, } \\
\text { reboques e carrocerias }\end{array}$ & 959 & 6.260 .313 & 286 & 2.913 .239 & 47 \\
\hline $\begin{array}{l}\text { Fabricação de outros equipamentos de } \\
\text { transporte }\end{array}$ & 180 & 5.077 .692 & 67 & 1.122 .820 & 22 \\
\hline Fabricação de móveis & 2.094 & 797.647 & 312 & 140.393 & 18 \\
\hline Fabricação de produtos diversos & 1.312 & 544.305 & 190 & 128.281 & 24 \\
\hline $\begin{array}{l}\text { Manutenção, reparação e instalação de } \\
\text { máquinas e equipamentos }\end{array}$ & 597 & 521.642 & 56 & 180.089 & 35 \\
\hline
\end{tabular}

Fonte: IBGE (2016). Extrato da Tabela 1.1.1 da Pintec 2014. Elaboração própria.

Atribui-se que as restrições observadas na geração das inovações por parte da maioria das empresas da indústria de transformação estejam diretamente relacionadas ao montante limitado que elas aplicam em P\&D interno: apenas 31\% do total do dispêndio em atividades inovativas, como mostra a tabela 3.4.

\subsection{1}

\section{Caracterização das empresas inovadoras}

Busca-se neste item, caracterizar as empresas inovadoras da indústria de transformação por faixa de pessoal ocupado e por tipo de inovação gerada - se produto e/ou produto novo ou com projetos incompletos e/ou abandonados (tabela 
3.5). Na sequência, evidencia-se o grau de novidade atribuído pelas empresas às inovações de processo e de processo (tabela 3.6).

Tabela 3.5 - Empresas da indústria de transformação que implementaram inovação de produto e/ou processo ou com projetos por faixa de pessoal ocupado: Brasil - 2014

\begin{tabular}{llllll}
\hline $\begin{array}{l}\text { Faixa de pessoal ocupado } \\
\text { na indústria de } \\
\text { transformação }\end{array}$ & \multicolumn{3}{l}{ Empresas que implementaram inovações } \\
\cline { 2 - 6 } & $\begin{array}{l}\text { Total de } \\
\text { empresas }\end{array}$ & $\begin{array}{l}\text { Inovação de } \\
\text { produto }\end{array}$ & $\begin{array}{l}\text { Inovação de } \\
\text { processo }\end{array}$ & $\begin{array}{l}\text { Inovação } \\
\text { de produto } \\
\text { e processo }\end{array}$ & $\begin{array}{l}\text { Com projetos } \\
\text { incompletos } \\
\text { ou } \\
\text { abandonados }\end{array}$ \\
\hline Total & $\mathbf{4 1 . 8 5 0}$ & $\mathbf{2 1 . 1 7 0}$ & $\mathbf{3 7 . 4 1 0}$ & $\mathbf{1 6 . 7 2 9}$ & $\mathbf{1 6 . 8 1 0}$ \\
\hline De 10 a 29 & 23.921 & 11.196 & 21.450 & 8.724 & 21.450 \\
\hline De 30 a 49 & 7.082 & 3.524 & 6.357 & 2.800 & 6.357 \\
\hline De 50 a 99 & 5.307 & 2.708 & 4.680 & 2.083 & 4.680 \\
\hline De 100 a 249 & 3.117 & 1.961 & 2.748 & 1.591 & 2.748 \\
\hline De 250 a 499 & 1.147 & 791 & 1.018 & 660 & 1.018 \\
\hline Com 500 e mais & 1.276 & 988 & 1.158 & 872 & 694 \\
\hline
\end{tabular}

Fonte: IBGE (2016). Tabulação especial solicitada pelo pesquisador ao IBGE.

Analisando-se os dados da tabela 3.5, verifica-se que na indústria de transformação, independente do porte da empresa, há um maior número de projetos implementados de inovação de processo, sendo que neste tipo de inovação, tanto as micro e pequenas, as médias e as grandes empresas estão no mesmo patamar, tendo cerca de $89 \%$ de seus projetos de inovação desse tipo.

As grandes empresas da indústria de transformação são as principais inovadoras em produtos, respondendo com $77 \%$ de seus projetos, seguida das médias empresas, que têm em suas carteiras $65 \%$ de projetos desse tipo e as pequenas empresas com 48\%. Já nas empresas que inovam em produto e processo, observam-se os seguintes percentuais de acordo com o tamanho da empresa: grandes (68\%); médias (53\%); e micro e pequenas $(37 \%)$.

Cabe ressaltar que as grandes empresas, tanto em produtos, como em processos, ou em ambos, são as que contribuem com os maiores percentuais nesses três tipos de inovação analisados.

A tabela 3.6, a seguir, mostra o grau de novidade atribuído pelas empresas da indústria de transformação às inovações de produto e/ou de processo, se novos para a empresa, mas existentes no mercado nacional; se novos para o mercado nacional, mas existentes no mercado mundial; ou se novos para o mercado mundial. 
Tabela 3.6 - Grau de novidade do principal produto e/ou principal processo nas empresas que implementaram inovações - Brasil - 2014

\begin{tabular}{|c|c|c|c|c|c|c|}
\hline \multirow[b]{3}{*}{ Atividades } & \multicolumn{6}{|c|}{$\begin{array}{l}\text { Grau de novidade do principal produto e/ou principal processo nas empresas que } \\
\text { implementaram inovações }\end{array}$} \\
\hline & \multicolumn{3}{|l|}{ Produto } & \multicolumn{3}{|l|}{ Processo } \\
\hline & $\begin{array}{l}\text { Novo para a } \\
\text { empresa, } \\
\text { mas } \\
\text { existente no } \\
\text { mercado } \\
\text { nacional }\end{array}$ & $\begin{array}{l}\text { Novo para o } \\
\text { mercado } \\
\text { nacional, mas } \\
\text { existente no } \\
\text { mercado } \\
\text { mundial }\end{array}$ & $\begin{array}{l}\text { Novo } \\
\text { para o } \\
\text { mercado } \\
\text { mundial }\end{array}$ & $\begin{array}{l}\text { Novo para a } \\
\text { empresa, mas } \\
\text { existente no } \\
\text { mercado } \\
\text { nacional }\end{array}$ & $\begin{array}{l}\text { Novo para o } \\
\text { mercado } \\
\text { nacional, mas } \\
\text { existente no } \\
\text { mercado } \\
\text { mundial }\end{array}$ & $\begin{array}{l}\text { Novo } \\
\text { para o } \\
\text { mercado } \\
\text { mundial }\end{array}$ \\
\hline $\begin{array}{l}\text { Indústria de } \\
\text { transformação }\end{array}$ & 16.634 & 4.046 & 490 & 34.033 & 3.077 & 300 \\
\hline $\begin{array}{l}\text { Fabricação de produtos } \\
\text { alimentícios }\end{array}$ & 3.183 & 188 & 17 & 4.975 & 352 & 112 \\
\hline Fabricação de bebidas & 155 & 10 & 1 & 378 & 10 & 2 \\
\hline $\begin{array}{l}\text { Fabricação de produtos } \\
\text { do fumo }\end{array}$ & 3 & 10 & - & 12 & 8 & 1 \\
\hline $\begin{array}{l}\text { Fabricação de produtos } \\
\text { têxteis }\end{array}$ & 366 & 89 & 11 & 1.090 & 54 & 7 \\
\hline $\begin{array}{l}\text { Confecção de artigos do } \\
\text { vestuário e acessórios }\end{array}$ & 1.644 & 337 & 3 & 4.309 & 120 & 3 \\
\hline $\begin{array}{l}\text { Preparação de couros e } \\
\text { fabricação de artefatos de } \\
\text { couro, artigos de viagem e } \\
\text { calçados }\end{array}$ & 611 & 177 & 8 & 1.125 & 42 & 7 \\
\hline $\begin{array}{l}\text { Fabricação de produtos } \\
\text { de madeira }\end{array}$ & 647 & 24 & 2 & 1.258 & 35 & 1 \\
\hline $\begin{array}{l}\text { Fabricação de celulose, } \\
\text { papel e produtos de papel }\end{array}$ & 186 & 35 & 10 & 589 & 35 & 3 \\
\hline $\begin{array}{l}\text { Impressão e reprodução } \\
\text { de gravações }\end{array}$ & 113 & 39 & 3 & 657 & 178 & 4 \\
\hline $\begin{array}{ll}\text { Fabricação de coque, de } \\
\text { produtos derivados } \\
\text { petróleo do } \\
\text { combustíveis }\end{array}$ & 47 & 5 & 1 & 99 & 16 & 2 \\
\hline $\begin{array}{l}\text { Fabricação de produtos } \\
\text { químicos }\end{array}$ & 855 & 325 & 60 & 1.120 & 299 & 20 \\
\hline $\begin{array}{lr}\text { Fabricação de } & \text { produtos } \\
\text { farmoquímicos } & \text { e } \\
\text { farmacêuticos } & \\
\end{array}$ & 111 & 36 & 12 & 159 & 23 & - \\
\hline $\begin{array}{l}\text { Fabricação de artigos de } \\
\text { borracha e plástico }\end{array}$ & 1.389 & 219 & 37 & 2.238 & 288 & 16 \\
\hline $\begin{array}{l}\text { Fabricação de produtos } \\
\text { de minerais não-metálicos }\end{array}$ & 1.601 & 116 & 8 & 3.598 & 320 & 3 \\
\hline Metalurgia & 147 & 33 & 8 & 606 & 40 & 7 \\
\hline $\begin{array}{l}\text { Fabricação de produtos } \\
\text { de metal }\end{array}$ & 1.306 & 287 & 24 & 2.883 & 220 & 14 \\
\hline $\begin{array}{lr}\text { Fabricação } & \text { de } \\
\text { equipamentos } & \text { de } \\
\text { informática, produtos } \\
\text { eletrônicos e ópticos }\end{array}$ & 491 & 397 & 23 & 772 & 89 & 18 \\
\hline $\begin{array}{l}\text { Fabricação de máquinas, } \\
\text { aparelhos e materiais } \\
\text { elétricos }\end{array}$ & 425 & 243 & 31 & 733 & 186 & 20 \\
\hline $\begin{array}{l}\text { Fabricação de máquinas e } \\
\text { equipamentos }\end{array}$ & 806 & 695 & 150 & 2.174 & 221 & 36 \\
\hline $\begin{array}{l}\text { Fabricação de veículos } \\
\text { automotores, reboques e } \\
\text { carrocerias }\end{array}$ & 428 & 269 & 34 & 732 & 147 & 11 \\
\hline $\begin{array}{lr}\text { Fabricação de } & \text { outros } \\
\text { equipamentos } & \text { de } \\
\text { transporte } & \\
\end{array}$ & 99 & 50 & 7 & 130 & 22 & 3 \\
\hline Fabricação de móveis & 1.077 & 249 & 7 & 2.464 & 81 & 3 \\
\hline $\begin{array}{l}\text { Fabricação de produtos } \\
\text { diversos }\end{array}$ & 635 & 184 & 22 & 1.155 & 228 & - \\
\hline $\begin{array}{l}\text { Manutenção, reparação } \\
\text { e instalação de máquinas } \\
\text { e equipamentos }\end{array}$ & 309 & 29 & 10 & 777 & 63 & 7 \\
\hline
\end{tabular}

Fonte: IBGE (2016). Extrato da Tabela 1.1.3 da Pintec 2014.

Analisando-se os dados da tabela 3.6, verifica-se que as principais empresas que implementaram inovações de produto (novo para a empresa, mas existente no 
nível nacional) foram: (i) fabricantes de produtos alimentícios (19\%); (ii) confecções de artigos de vestuário e acessórios (10\%) e os (iii) fabricantes de produtos não-metálicos (10\%). Observa-se também que, dentre os diversos setores da indústria de transformação, o que mais inovou em produto, atribuindo um grau de novidade como sendo novo para o mercado nacional, mas existente a nível mundial, foram os fabricantes de máquinas e equipamentos (17\%). Os demais setores estão num patamar bem abaixo. Destacam-se também os dois principais setores que inovaram em produtos, sendo essas inovações classificadas como novas a nível mundial. São os fabricantes de máquinas e equipamentos (31\%) e fabricantes de produtos químicos (12\%).

Já os setores que se destacam em inovações de seu principal processo com o grau de novidade para a empresa mas já existente no mercado nacional são os seguintes: (i) fabricação de produtos alimentícios (15\%); (ii) confecção de artigos de vestuário e acessórios (13\%) e (iii) fabricação de produtos de minerais nãometálicos (11\%). Quando se avalia as inovações de processo no nível de novidade para o mercado nacional, mas já existente em nível mundial, há três principais setores que se destacam, e eles estão no mesmo patamar em termos percentuais, a saber: fabricantes de produtos alimentícios (11\%), fabricantes de produtos químicos $(10 \%)$ e os fabricantes de produtos minerais não-metálicos $(10 \%)$. É também o setor de alimentos que responde pelo maior percentual de inovações de seu principal processo com grau de novidade pera o mercado mundial, correspondendo a $37 \%$ de toda a indústria de transformação.

\subsection{3.}

\section{Atividades inovativas}

Apresentam-se neste item os dados sobre empresas que implementaram inovações, por grau de importância das atividades inovativas desenvolvidas, a saber: (i) atividades internas de $\mathrm{P} \& \mathrm{D}$; (ii) aquisição externa de $\mathrm{P} \& \mathrm{D}$; (iii) aquisição de outros conhecimentos externos; (iv) aquisição de software; (v) aquisição de máquinas e equipamentos; (vi) treinamento; (vii) introdução das inovações tecnológicas no mercado; e (viii) projeto industrial e outras preparações técnicas (tabela 3.7). 
Tabela 3.7- Empresas que implementaram inovações, por grau de importância das atividades inovativas desenvolvidas, segundo atividades da indústria de transformação - Brasil - 2014

\begin{tabular}{|c|c|c|c|c|c|c|c|c|c|c|c|c|c|}
\hline \multirow{4}{*}{ Atividades } & \multicolumn{13}{|c|}{ Empresas que implementaram inovações } \\
\hline & \multirow{3}{*}{ Total } & \multicolumn{12}{|c|}{ Atividades inovativas desenvolvidas e grau de importância } \\
\hline & & \multicolumn{3}{|c|}{ Atividades internas de P\&D } & \multicolumn{3}{|c|}{ Aquisição externa de P\&D } & \multicolumn{3}{|c|}{$\begin{array}{l}\text { Aquisição de outros } \\
\text { conhecimentos externos }\end{array}$} & \multicolumn{3}{|c|}{ Aquisição de software } \\
\hline & & Alta & Média & Baixa* $^{*}$ & Alta & Média & Baixa* $^{*}$ & Alta & Média & Baixa* & Alta & Média & Baixa* $^{*}$ \\
\hline Indústria de transformação & 41.850 & 4.356 & 2.124 & 35.369 & 1.279 & 933 & 39.637 & 3.770 & 2.343 & 35.737 & 9.045 & 4.242 & 28.563 \\
\hline Fabricação de produtos alimentícios & 6.168 & 490 & 237 & 5441 & 185 & 161 & 5.822 & 545 & 399 & 5225 & 691 & 660 & 4817 \\
\hline Fabricação de bebidas & 423 & 76 & 24 & 322 & 16 & 5 & 402 & 108 & 4 & 310 & 87 & 10 & 325 \\
\hline Fabricação de produtos do fumo & 24 & 10 & 1 & 13 & - & 1 & 23 & 1 & - & 23 & 1 & 3 & 20 \\
\hline Fabricação de produtos têxteis & 1.234 & 50 & 35 & 1.149 & 15 & 109 & 1.110 & 177 & 35 & 1.023 & 138 & 184 & 913 \\
\hline Confecção de artigos do vestuário e acessórios & 5.107 & 64 & 96 & 4.946 & 10 & 95 & 5.001 & 325 & 430 & 4351 & 1.568 & 648 & 2.891 \\
\hline Preparação de couros e fabricação de artefatos & 1.415 & 65 & 7 & 1.343 & 11 & 14 & 1.391 & 293 & 37 & 1.086 & 357 & 110 & 947 \\
\hline Fabricação de produtos de madeira & 1.325 & 14 & 18 & 1.292 & 13 & 5 & 1.307 & 92 & 31 & 1.202 & 53 & 396 & 875 \\
\hline Fabricação de celulose, papel e produtos de papel & 647 & 38 & 24 & 585 & 16 & 3 & 627 & 18 & 15 & 614 & 88 & 41 & 518 \\
\hline Impressão e reprodução de gravações & 839 & 46 & 2 & 790 & 17 & - & 822 & 169 & 3 & 667 & 415 & 93 & 331 \\
\hline $\begin{array}{l}\text { Fabricação de coque, de produtos derivados do } \\
\text { petróleo e de combustiveis }\end{array}$ & 125 & 13 & 15 & 97 & 16 & 9 & 99 & 9 & 11 & 104 & 41 & 12 & 73 \\
\hline Fabricação de produtos químicos & 1.802 & 786 & 231 & 784 & 77 & 69 & 1.656 & 201 & 65 & 1.536 & 396 & 112 & 1.294 \\
\hline $\begin{array}{l}\text { Fabricação de produtos farmoquímicos e } \\
\text { farmacêuticos }\end{array}$ & 212 & 87 & 64 & 61 & 34 & 60 & 118 & 35 & 19 & 158 & 48 & 8 & 156 \\
\hline Fabricação de artigos de borracha e plástico & 2.925 & 180 & 171 & 2.574 & 210 & 48 & 2667 & 312 & 136 & 2477 & 545 & 215 & 2.166 \\
\hline Fabricação de produtos de minerais não-metálicos & 4.229 & 84 & 63 & 4.082 & 59 & 16 & 4154 & 262 & 238 & 3729 & 522 & 210 & 3.496 \\
\hline Metalurgia & 669 & 81 & 17 & 571 & 31 & 12 & 625 & 24 & 24 & 621 & 125 & 36 & 508 \\
\hline Fabricação de produtos de metal & 3.513 & 427 & 290 & 2.796 & 35 & 38 & 3440 & 120 & 293 & 3100 & 725 & 198 & 2.590 \\
\hline $\begin{array}{l}\text { Fabricação de equipamentos de informática, } \\
\text { produtos eletrônicos e ópticos }\end{array}$ & 1.053 & 384 & 92 & 577 & 86 & 34 & 933 & 108 & 35 & 910 & 257 & 176 & 620 \\
\hline $\begin{array}{l}\text { Fabricação de máquinas, aparelhos e materiais } \\
\text { elétricos }\end{array}$ & 1.022 & 233 & 199 & 589 & 65 & 68 & 889 & 54 & 79 & 889 & 310 & 79 & 633 \\
\hline Fabricação de máquinas e equipamentos & 2.657 & 519 & 194 & 1.945 & 64 & 64 & 2529 & 247 & 151 & 2260 & 790 & 275 & 1.593 \\
\hline $\begin{array}{l}\text { Fabricação de veículos automotores, reboques e } \\
\text { carrocerias }\end{array}$ & 1.080 & 227 & 109 & 745 & 67 & 39 & 974 & 153 & 52 & 876 & 271 & 96 & 713 \\
\hline Fabricação de outros equipamentos de transporte & 227 & 50 & 18 & 158 & 9 & 10 & 208 & 18 & 9 & 199 & 63 & 15 & 149 \\
\hline Fabricação de móveis & 2.714 & 242 & 91 & 2.382 & 211 & 55 & 2.448 & 113 & 214 & 2388 & 829 & 282 & 1.603 \\
\hline Fabricação de produtos diversos & 1.504 & 144 & 117 & 1.243 & 29 & 14 & 1.461 & 336 & 14 & 1154 & 491 & 233 & 780 \\
\hline Manutenção/instalação de máq. e equipamentos & 937 & 44 & 8 & 885 & 2 & 4 & 931 & 51 & 50 & 835 & 235 & 150 & 552 \\
\hline
\end{tabular}

Nota: $\left({ }^{*}\right)$ baixa importância ou não realizou a atividade inovativa.

Fonte: IBGE (2016). Extrato da Tabela 1.1.6 da Pintec 2014. Elaboração própria. 
Tabela 3.7 - Empresas que implementaram inovações, por grau de importância das atividades inovativas desenvolvidas, segundo atividades da indústria de transformação - Brasil - 2014 (cont.)

\begin{tabular}{|c|c|c|c|c|c|c|c|c|c|c|c|c|c|}
\hline \multirow{4}{*}{ Atividades } & \multicolumn{13}{|c|}{ Empresas que implementaram inovações } \\
\hline & \multirow{3}{*}{ Total } & \multicolumn{12}{|c|}{ Atividades inovativas desenvolvidas e grau de importância } \\
\hline & & \multicolumn{3}{|c|}{$\begin{array}{l}\text { Aquisição de máquinas e } \\
\text { equipamentos }\end{array}$} & \multicolumn{3}{|c|}{ Treinamento } & \multicolumn{3}{|c|}{$\begin{array}{l}\text { Introdução das inovações } \\
\text { tecnológicas no mercado }\end{array}$} & \multicolumn{3}{|c|}{$\begin{array}{l}\text { Projeto industrial e outras } \\
\text { preparaçōes técnicas }\end{array}$} \\
\hline & & Alta & Média & Baixa & Alta & Média & Baixa & Alta & Média & Baixa & Alta & Média & Baixa \\
\hline Indústria de transformação & 41.850 & 22.374 & 8.445 & 11.032 & 18.137 & 7.666 & 16.046 & 7.204 & 5.699 & 28.946 & 7.493 & 5.527 & 28.829 \\
\hline Fabricação de produtos alimentícios & 6.168 & 3.517 & 1.280 & 1.371 & 2.326 & 1.388 & 2454 & 856 & 753 & 4.559 & 1.042 & 788 & 4.338 \\
\hline Fabricação de bebidas & 423 & 235 & 82 & 106 & 261 & 42 & 119 & 110 & 144 & 168 & 43 & 62 & 318 \\
\hline Fabricação de produtos do fumo & 24 & 13 & 3 & 8 & 15 & 1 & 8 & 1 & 2 & 21 & 11 & 7 & 6 \\
\hline Fabricação de produtos têxteis & 1.234 & 623 & 249 & 362 & 345 & 264 & 626 & 136 & 214 & 884 & 138 & 171 & 926 \\
\hline Confecção de artigos do vestuário e acessórios & 5.107 & 2460 & 993 & 1653 & 2180 & 786 & 2141 & 651 & 845 & 3611 & 459 & 598 & 4.050 \\
\hline Preparação de couros e fabricação de artefatos & 1.415 & 658 & 406 & 351 & 460 & 298 & 657 & 151 & 281 & 984 & 161 & 217 & 1.038 \\
\hline Fabricação de produtos de madeira & 1.325 & 927 & 272 & 125 & 432 & 402 & 491 & 338 & 72 & 915 & 171 & 149 & 1.005 \\
\hline Fabricação de celulose, papel e produtos de papel & 647 & 440 & 69 & 138 & 362 & 114 & 171 & 125 & 56 & 466 & 48 & 53 & 545 \\
\hline Impressão e reprodução de gravações & 839 & 577 & 133 & 129 & 551 & 89 & 199 & 140 & 125 & 574 & 56 & 148 & 635 \\
\hline $\begin{array}{l}\text { Fabricação de coque, de produtos derivados do } \\
\text { petróleo e de combustíveis }\end{array}$ & 125 & 83 & 27 & 15 & 69 & 6 & 50 & 35 & 5 & 85 & 29 & 11 & 85 \\
\hline Fabricação de produtos químicos & 1.802 & 740 & 371 & 690 & 865 & 315 & 622 & 672 & 197 & 933 & 454 & 231 & 1.117 \\
\hline $\begin{array}{l}\text { Fabricação de produtos farmoquímicos } \\
\text { farmacêuticos }\end{array}$ & 212 & 74 & 45 & 92 & 85 & 71 & 57 & 62 & 56 & 93 & 28 & 77 & 107 \\
\hline Fabricação de artigos de borracha e plástico & 2.925 & 1.326 & 734 & 864 & 1.084 & 427 & 1.414 & 572 & 312 & 2.041 & 540 & 345 & 2.041 \\
\hline Fabricação de produtos de minerais não-metálicos & 4.229 & 2.832 & 608 & 789 & 1.569 & 805 & 1855 & 470 & 542 & 3.217 & 715 & 680 & 2.835 \\
\hline Metalurgia & 669 & 233 & 124 & 311 & 310 & 122 & 237 & 65 & 44 & 560 & 99 & 45 & 525 \\
\hline Fabricação de produtos de metal & 3.513 & 2. 180 & 543 & 790 & 1.755 & 599 & 1159 & 610 & 203 & 2.700 & 686 & 502 & 2.325 \\
\hline $\begin{array}{l}\text { Fabricação de equipamentos de informática, } \\
\text { produtos eletrônicos e ópticos }\end{array}$ & 1.053 & 487 & 195 & 371 & 416 & 202 & 434 & 303 & 214 & 536 & 293 & 110 & 649 \\
\hline $\begin{array}{l}\text { Fabricação de máquinas, aparelhos e materiais } \\
\text { elétricos }\end{array}$ & 1.022 & 482 & 212 & 328 & 515 & 233 & 274 & 186 & 147 & 689 & 191 & 178 & 652 \\
\hline Fabricação de máquinas e equipamentos & 2.657 & 1.208 & 398 & 1051 & 1.099 & 668 & 890 & 448 & 556 & 1.653 & 766 & 384 & 1.507 \\
\hline $\begin{array}{l}\text { Fabricação de veículos automotores, reboques e } \\
\text { carrocerias }\end{array}$ & 1.080 & 499 & 303 & 279 & 507 & 96 & 477 & 250 & 154 & 676 & 141 & 255 & 684 \\
\hline Fabricação de outros equipamentos de transporte & 227 & 114 & 40 & 73 & 106 & 27 & 94 & 62 & 34 & 131 & 44 & 57 & 125 \\
\hline Fabricação de móveis & 2.714 & 1.540 & 862 & 312 & 1.500 & 553 & 661 & 492 & 431 & 1.792 & 788 & 229 & 1.697 \\
\hline Fabricação de produtos diversos & 1.504 & 842 & 334 & 328 & 774 & 113 & 617 & 406 & 204 & 894 & 348 & 214 & 941 \\
\hline Manutenção/instalação de máq. e equipamentos & 937 & 284 & 160 & 493 & 550 & 46 & 340 & 63 & 107 & 766 & 244 & 15 & 678 \\
\hline
\end{tabular}

Nota: $\left(^{*}\right)$ baixa importância ou não realizou a atividade inovativa.

Fonte: IBGE (2016). Extrato da Tabela 1.1.6 da Pintec 2014. Elaboração própria. 
Dentre as 24 atividades da indústria de transformação que implementaram inovações e que consideram as atividades inovativas com grau de importância alta, destacam-se: fabricantes de produtos alimentícios que atribuiu, em média percentual, 12,75\% para cada tipo de atividade, seguido dos fabricantes de equipamentos, com um percentual médio de $7,5 \%$ e dos fabricantes de produtos químicos (7\%).

Para as atividades da indústria de transformação que consideraram as atividades inovativas com grau de importância média destacam-se os fabricantes de produtos alimentícios, com um percentual médio para cada tipo de atividade de 15,38; as confecções de artigos de vestuário e acessórios, que atribuiu, em média, $12 \%$ e os fabricantes de produtos de metal, com um percentual médio de $8,88 \%$.

Já as atividades da indústria de transformação que consideraram as atividades inovativas com baixo grau de importância foram: fabricantes de produtos alimentícios (15\%); confecção de artigos de vestuário e acessórios (12,88\%) e fabricação de produtos de minerais não-metálicos (10,5\%).

\subsection{4.}

\section{Cooperação interorganizacional para inovação}

Neste item apresenta-se a visão das empresas que implementaram inovações (total e com relações de cooperação com outras organizações), segundo as atividades da indústria, por grau de importância atribuída aos seguintes parceiros: (i) clientes ou consumidores; (ii) fornecedores; (iii) concorrentes; (iv) outra empresa do grupo; (v) empresas de consultoria; (vi) universidades e institutos de pesquisa; (vii) centros de capacitação profissional e assistência técnica; e (viii) instituições de ensaios e certificações (tabela 3.8). 
Tabela 3.8 - Empresas que implementaram inovações, total e com relações de cooperação com outras organizações, por grau de importância da parceria, segundo atividades da indústria de transformação - Brasil - 2014

\section{Atividades}

Empresas que implementaram inovações com relações de cooperação com outras organizações

Parceiros da cooperação interorganizacional e grau de importância

Total Clientes ou consumidores Fornecedores

$\begin{array}{llll}\text { Clentes ou consumidores } & \text { Fornecedores } & \text { Concorrentes } & \text { Outra empresa do grupo }\end{array}$

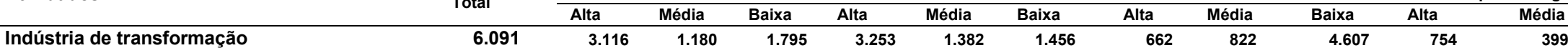

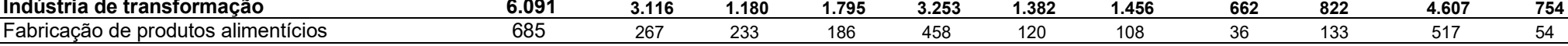
Fabricacão de produs alm

\begin{tabular}{lllllll}
685 & 267 & 233 & 186 & 458 & 120 & 108 \\
\hline
\end{tabular}

Fabricação de produtos do fumo

Fabricação de produtos têxteis

Confecção de artigos do vestuário e acessórios Preparação de couros e fabricação de artefatos

Fabricação de produtos de madeira

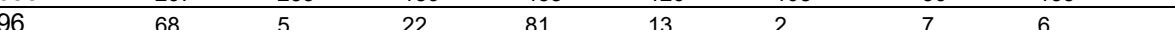
273

Impressão e reprodução de gravações

Fabricação de coque de produtos derivados do

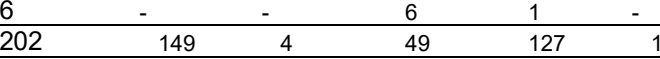

\begin{tabular}{|c|c|c|c|c|c|c|c|c|c|c|c|}
\hline 149 & 4 & 49 & 127 & 13 & 63 & 12 & 6 & 185 & 21 & 5 & 176 \\
\hline 229 & 4 & 138 & 161 & 112 & 98 & 76 & 79 & 216 & 1 & 7 & 363 \\
\hline
\end{tabular}

\begin{tabular}{lllllllllllll}
24 & 106 & 143 & 154 & 46 & 72 & 4 & 53 & 216 & 5 & 1 & 267 \\
\hline
\end{tabular}

$\begin{array}{llllllllll}64 & 32 & 14 & 18 & 22 & 32 & 10 & 5 & 8 & 50 \\ 59 & 36 & 7 & 16 & 39 & 5 & 15 & 3 & 6 & 49\end{array}$

36

Fabricacão de produtos químid

Fabricação de produtos farmoquímicos e

farmacêuticos produs farmoquímicos

Fabricação de artigos de borracha e plástico

Fabricação de produtos de minerais não-metálicos

Metalurgia

\begin{tabular}{llllll}
36 & 7 & 16 & 39 & 5 & 15 \\
\hline & 1 & 44 & 63 & 5 & 5
\end{tabular}

\begin{tabular}{lllllllllllll}
36 & 5 & 4 & 27 & 11 & 5 & 20 & 4 & 3 & 29 & 16 & -20 \\
\hline 542 & 373 & 71 & 98 & 375 & 87 & 79 & 62 & 55 & 424 & 116 & 33 & 393
\end{tabular}

Fabricação de equipamentos de informática,

\begin{tabular}{lllllllllllll}
98 & 30 & 20 & 49 & 56 & 17 & 24 & 21 & 14 & 63 & 23 & 10 & 65 \\
350 & 246 & 28 & 77 & 130 & 61 & 160 & 4 & 16 & 330 & 35 & 14 & 302 \\
\hline 430 & 216 & 42 & 172 & 229 & 157 & 44 & 20 & 86 & 324 & 67 & 39 & 324
\end{tabular}

\begin{tabular}{|c|c|c|c|c|c|c|c|c|c|c|c|c|}
\hline 130 & 216 & 42 & 172 & 229 & 157 & 44 & 20 & 86 & 324 & 67 & 39 & 324 \\
\hline 146 & 111 & 16 & 18 & 92 & 27 & 27 & 60 & 6 & 80 & 26 & 6 & 114 \\
\hline
\end{tabular}

Fabricação de máquinas, ap. e materiais estri

Fabricação de veículos automotores, reboques $e$

carrocerias Fabricação de móveis

Fabricacão de produtos diversos

$\begin{array}{lll}111 & 16 & 18\end{array}$

$\begin{array}{ll}92 & 27 \\ 285 & 73\end{array}$

\begin{tabular}{lllllllllllll}
317 & 136 & 126 & 55 & 126 & 106 & 85 & 17 & 107 & 192 & 26 & 19 & 271 \\
267 & 80 & 131 & 56 & 85 & 49 & 134 & 8 & 9 & 251 & 45 & 12 & 210 \\
439 & 211 & 98 & 129 & 178 & 169 & 92 & 20 & 37 & 383 & 51 & 24 & 364 \\
\hline
\end{tabular}

te produtos diversos

equipamentos

\begin{tabular}{lllllllllllll}
247 & 172 & 26 & 50 & 71 & 89 & 88 & 8 & 61 & 178 & 61 & 15 & 171 \\
\hline 53 & 36 & 1 & 16 & 24 & 5 & 24 & 3 & 9 & 41 & 23 & 3 & 28 \\
\hline 418 & 175 & 23 & 220 & 206 & 131 & 81 & 64 & 54 & 299 & 11 & 49 & 358 \\
\hline 245 & 160 & 25 & 60 & 141 & 58 & 46 & 50 & 36 & 159 & 8 & 25 & 213 \\
\hline 214 & 59 & 116 & 39 & 138 & 2 & 74 & 120 & 1 & 93 & 11 & 1 & 202
\end{tabular}

Fonte: IBGE (2016). Extrato da Tabela 1.1.17 da Pintec 2014. 
Tabela 3.8 - Empresas que implementaram inovações, total e com relações de cooperação com outras organizações, por grau de importância da parceria, segundo atividades da indústria de transformação - Brasil - 2014 (cont.)

\begin{tabular}{|c|c|c|c|c|c|c|c|c|c|c|c|c|c|}
\hline \multirow{4}{*}{ Atividades } & \multirow{4}{*}{ Total } & \multicolumn{12}{|c|}{ Empresas que implementaram inovações com relações de cooperação com outras organizações } \\
\hline & & \multicolumn{12}{|c|}{ Parceiros da cooperação interorganizacional e grau de importância } \\
\hline & & \multicolumn{3}{|c|}{ Empresas de consultoria } & \multicolumn{3}{|c|}{$\begin{array}{l}\text { Universidades e institutos de } \\
\text { pesquisa }\end{array}$} & \multicolumn{3}{|c|}{$\begin{array}{l}\text { Centros de capacitação } \\
\text { profissional } \\
\text { e assistência técnica }\end{array}$} & \multicolumn{3}{|c|}{$\begin{array}{l}\text { Instituições de ensaios e } \\
\text { certificações }\end{array}$} \\
\hline & & Alta & Média & Baixa & Alta & Média & Baixa & Alta & Média & Baixa & Alta & Média & Baixa \\
\hline Indústria de transformação & 6.091 & 971 & 1.025 & 4.095 & 874 & 579 & 4.638 & 677 & 901 & 4.512 & 1.130 & 935 & 4.026 \\
\hline Fabricação de produtos alimentícios & 685 & 119 & 104 & 462 & 202 & 38 & 445 & 38 & 178 & 470 & 103 & 148 & 434 \\
\hline Fabricação de bebidas & 96 & 4 & 64 & 28 & 9 & 10 & 77 & 46 & 9 & 41 & 51 & 5 & 40 \\
\hline Fabricação de produtos do fumo & 6 & - & - & 6 & 5 & 1 & - & - & - & 6 & - & - & 6 \\
\hline Fabricação de produtos têxteis & 202 & 15 & 87 & 101 & 16 & 79 & 108 & 19 & 18 & 165 & 102 & 10 & 91 \\
\hline Confecção de artigos do vestuário e acessórios & 371 & 96 & 7 & 267 & 4 & 10 & 356 & 110 & 12 & 249 & 7 & 8 & 356 \\
\hline Preparação de couros e fabricação de artefatos & 273 & 6 & 43 & 224 & 6 & 3 & 264 & 5 & 36 & 233 & 75 & 104 & 93 \\
\hline Fabricação de produtos de madeira & 64 & 3 & 8 & 53 & 3 & 3 & 57 & 2 & 9 & 52 & 4 & 8 & 51 \\
\hline Fabricação de celulose, papel e produtos de papel & 59 & 17 & 4 & 38 & 10 & 2 & 47 & 9 & 4 & 46 & 19 & 7 & 34 \\
\hline Impressão e reprodução de gravações & 73 & 6 & 28 & 40 & 31 & 29 & 12 & 27 & - & 46 & 24 & 3 & 46 \\
\hline $\begin{array}{l}\text { Fabricação de coque, de produtos derivados do } \\
\text { petróleo e de combustiveis }\end{array}$ & 36 & 9 & 2 & 25 & 10 & 8 & 18 & 10 & 3 & 23 & 12 & 5 & 19 \\
\hline Fabricação de produtos químicos & 542 & 116 & 76 & 350 & 104 & 114 & 323 & 75 & 68 & 399 & 119 & 86 & 337 \\
\hline $\begin{array}{l}\begin{array}{l}\text { Fabricação de produtos farmoquímicos } \\
\text { farmacêuticos }\end{array} \\
\end{array}$ & 98 & 21 & 25 & 51 & 38 & 18 & 41 & 16 & 9 & 72 & 26 & 19 & 52 \\
\hline Fabricação de artigos de borracha e plástico & 350 & 23 & 37 & 291 & 36 & 23 & 291 & 17 & 29 & 304 & 58 & 94 & 199 \\
\hline Fabricação de produtos de minerais não-metálicos & 430 & 78 & 21 & 332 & 47 & 12 & 372 & 29 & 63 & 339 & 77 & 32 & 322 \\
\hline Metalurgia & 146 & 27 & 49 & 69 & 22 & 7 & 117 & 16 & 52 & 78 & 21 & 18 & 107 \\
\hline Fabricação de produtos de metal & 460 & 48 & 117 & 295 & 31 & 59 & 371 & 17 & 101 & 342 & 87 & 76 & 297 \\
\hline $\begin{array}{l}\text { Fabricação de equipamentos de informática, } \\
\text { produtos eletrônicos e ópticos }\end{array}$ & 317 & 75 & 35 & 206 & 117 & 36 & 164 & 19 & 35 & 263 & 62 & 24 & 231 \\
\hline Fabricação de máquinas, ap. e materiais elétricos & 267 & 10 & 37 & 220 & 32 & 17 & 219 & 9 & 19 & 239 & 45 & 38 & 183 \\
\hline Fabricação de máquinas e equipamentos & 439 & 27 & 40 & 372 & 41 & 55 & 343 & 38 & 65 & 336 & 58 & 55 & 327 \\
\hline $\begin{array}{l}\text { Fabricação de veículos automotores, reboques e } \\
\text { carrocerias }\end{array}$ & 247 & 21 & 29 & 197 & 11 & 21 & 215 & 10 & 14 & 222 & 31 & 17 & 199 \\
\hline Fabricação de outros equipamentos de transporte & 53 & 5 & 4 & 44 & 5 & 9 & 39 & 6 & 6 & 41 & 5 & 7 & 40 \\
\hline Fabricação de móveis & 418 & 107 & 178 & 134 & 53 & 17 & 347 & 80 & 151 & 187 & 105 & 115 & 198 \\
\hline Fabricação de produtos diversos & 245 & 102 & 24 & 119 & 38 & 8 & 199 & 72 & 11 & 161 & 23 & 50 & 172 \\
\hline $\begin{array}{l}\text { Manutenção/instalação de máquinas e } \\
\text { equipamentos }\end{array}$ & 214 & 35 & 7 & 171 & 2 & - & 211 & 7 & 9 & 198 & 14 & 8 & 191 \\
\hline
\end{tabular}

Fonte: IBGE (2016). Extrato da Tabela 1.1.17 da Pintec 2014. 
Tomando-se como base nos dados da tabela 3.8, calculou-se a média dos valores percentuais referentes à importância atribuída pelas empresas aos diferentes tipos de parceiros (alta, média e baixa importância). Destacam-se as seguintes atividades industrias que consideraram como sendo de alta importância as parcerias: (i) fabricação de produtos químicos (12\%); (ii) fabricação de produtos alimentícios (11\%); e (iii) fabricação de produtos de metal (7\%).

Para empresas que implementaram inovações e que atribuíram média importância às parcerias com outras organizações, destacam-se as seguintes atividades da indústria de transformação: (i) fabricação de produtos alimentícios (16\%); (ii) fabricação de máquinas e equipamentos (7,1\%); e (iii) fabricação de equipamentos de informática, produtos elétricos e ópticos (6,6\%). Já as principais atividades que consideram de baixa importância as parcerias para cooperação são: (i) fabricação de produtos alimentícios (10\%); (ii) fabricação de produtos de minerais não-metálicos $(7,4 \%)$; e (iii) fabricação de móveis $(6,3 \%)$.

Cabe ressaltar que dentre todas as atividades da indústria de transformação a fabricação de produtos alimentícios se destaca como tendo empresas desse ramo que dão importância às parcerias para se implementar inovações e é nessa atividade que se evidenciam como sendo os principais tipos de parceria aquelas realizadas com outras empresas do grupo, universidades e institutos de pesquisa e clientes ou consumidores finais.

\subsection{5. \\ Impactos das inovações geradas}

Apresenta-se, a seguir, o quadro das empresas que implementaram inovações, segundo as atividades da indústria de transformação, por grau de importância do impacto causado, a saber: (i) melhoria da qualidade dos produtos; (ii) ampliação da gama de produtos ofertados; (iii) manutenção da participação da empresa no mercado; (iv) ampliação da participação da empresa no mercado; (v) abertura de novos mercados; (vi) aumento da capacidade produtiva; (vii) aumento da flexibilidade da produção; (viii) redução dos custos de produção; (ix) redução dos custos do trabalho; (x) redução do consumo de matéria-prima; (xi) redução do consumo de energia; (xii) redução do consumo de água; (xiii) redução do impacto ambiental e/ou em aspectos ligados à saúde e segurança; (xiv) redução do impacto ambiental; (xv) ampliação do controle de aspectos ligados à saúde e segurança; (xvi) enquadramento em regulações e normas (tabela 3.9). 
Tabela 3.9 - Empresas que implementaram inovações, por grau de importância do impacto causado, segundo atividades da indústria de transformação Brasil -2014

\begin{tabular}{|c|c|c|c|c|c|c|c|c|c|c|c|c|c|}
\hline \multirow{4}{*}{ Atividades } & \multicolumn{13}{|c|}{ Empresas que implementaram inovações } \\
\hline & \multirow{3}{*}{ Total } & \multicolumn{12}{|c|}{ Impacto causado e grau de importância } \\
\hline & & \multicolumn{3}{|c|}{$\begin{array}{l}\text { Melhoria da qualidade dos } \\
\text { produtos }\end{array}$} & \multicolumn{3}{|c|}{$\begin{array}{l}\text { Ampliação da gama de produtos } \\
\text { ofertados }\end{array}$} & \multicolumn{3}{|c|}{$\begin{array}{l}\text { Manutenção da participação da } \\
\text { empresa no mercado }\end{array}$} & \multicolumn{3}{|c|}{$\begin{array}{l}\text { Ampliação da participação da } \\
\text { empresa no mercado }\end{array}$} \\
\hline & & Alta & Média & Baixa & Alta & Média & Baixa & Alta & Média & Baixa & Alta & Média & Baixa \\
\hline Indústria de transformação & 41.850 & 21.673 & 12.047 & 8.130 & 9.750 & 7.960 & 24.139 & 18.453 & 15.563 & 7.834 & 14.153 & 14.635 & 13.062 \\
\hline Fabricação de produtos alimentícios & 6.168 & 2.886 & 1.919 & 1.363 & 1.628 & 1.058 & 3.482 & 2.315 & 1.986 & 1.867 & 2.100 & 2.000 & 2.069 \\
\hline Fabricação de bebidas & 423 & 239 & 141 & 43 & 47 & 91 & 285 & 189 & 195 & 40 & 204 & 82 & 137 \\
\hline Fabricação de produtos do fumo & 24 & 5 & 7 & 12 & 1 & 11 & 12 & 2 & 17 & 5 & 1 & 9 & 14 \\
\hline Fabricação de produtos têxteis & 1.234 & 536 & 292 & 407 & 192 & 217 & 825 & 414 & 630 & 190 & 261 & 558 & 415 \\
\hline Confecção de artigos do vestuário e acessórios & 5.107 & 2.435 & 1.567 & 1.104 & 1.296 & 844 & 2.967 & 2.577 & 1.537 & 993 & 1.463 & 1.866 & 1.778 \\
\hline Preparação de couros e fabricação de artefatos & 1.415 & 1.006 & 256 & 154 & 336 & 469 & 610 & 499 & 611 & 305 & 385 & 496 & 534 \\
\hline Fabricação de produtos de madeira & 1.325 & 823 & 182 & 320 & 338 & 323 & 663 & 545 & 414 & 366 & 721 & 437 & 166 \\
\hline Fabricação de celulose, papel e produtos de papel & 647 & 211 & 109 & 326 & 156 & 51 & 440 & 114 & 471 & 62 & 181 & 150 & 316 \\
\hline Impressão e reprodução de gravações & 839 & 477 & 191 & 171 & 92 & 55 & 691 & 443 & 185 & 211 & 505 & 106 & 228 \\
\hline $\begin{array}{l}\text { Fabricação de coque, de produtos derivados do } \\
\text { petróleo e de combustiveis }\end{array}$ & 125 & 61 & 19 & 45 & 29 & 17 & 79 & 50 & 34 & 41 & 34 & 46 & 45 \\
\hline Fabricação de produtos químicos & 1.802 & 1.029 & 398 & 375 & 682 & 427 & 693 & 909 & 475 & 418 & 809 & 489 & 504 \\
\hline $\begin{array}{l}\text { Fabricação de produtos farmoquímicos } \\
\text { farmacêuticos }\end{array}$ & 212 & 82 & 68 & 62 & 49 & 87 & 76 & 120 & 58 & 34 & 98 & 74 & 40 \\
\hline Fabricação de artigos de borracha e plástico & 2.925 & 1.235 & 1089 & 600 & 486 & 726 & 1713 & 1.407 & 1.075 & 443 & 891 & 1.313 & 721 \\
\hline Fabricação de produtos de minerais não-metálicos & 4.229 & 2.371 & 1.133 & 725 & 662 & 477 & 3.091 & 1.851 & 1.821 & 558 & 1.105 & 1.584 & 1.540 \\
\hline Metalurgia & 669 & 250 & 204 & 214 & 86 & 66 & 517 & 213 & 270 & 185 & 191 & 214 & 264 \\
\hline Fabricação de produtos de metal & 3.513 & 1.908 & 986 & 619 & 876 & 452 & 2.185 & 1.548 & 1.413 & 552 & 1.261 & 1.269 & 983 \\
\hline $\begin{array}{l}\text { Fabricação de equipamentos de informática, } \\
\text { produtos eletrônicos e ópticos }\end{array}$ & 1.053 & 719 & 163 & 170 & 232 & 388 & 432 & 615 & 237 & 201 & 488 & 239 & 325 \\
\hline Fabricação de máquinas, ap. e materiais elétricos & 1.022 & 599 & 285 & 138 & 266 & 379 & 377 & 702 & 214 & 106 & 433 & 367 & 222 \\
\hline Fabricação de máquinas e equipamentos & 2.657 & 222 & 69 & 56 & 142 & 112 & 93 & 189 & 108 & 51 & 115 & 101 & 132 \\
\hline $\begin{array}{l}\text { Fabricação de veículos automotores, reboques e } \\
\text { carrocerias }\end{array}$ & 1.080 & 1.362 & 996 & 299 & 568 & 764 & 1325 & 1.222 & 1.073 & 362 & 823 & 952 & 883 \\
\hline Fabricação de outros equipamentos de transporte & 227 & 527 & 305 & 248 & 332 & 253 & 496 & 434 & 517 & 129 & 302 & 529 & 250 \\
\hline Fabricação de móveis & 2.714 & 153 & 31 & 44 & 95 & 37 & 95 & 120 & 79 & 28 & 110 & 58 & 59 \\
\hline Fabricação de produtos diversos & 1.504 & 1.609 & 910 & 195 & 789 & 411 & 1514 & 1.278 & 1.136 & 300 & 908 & 884 & 922 \\
\hline $\begin{array}{l}\text { Manutenção/instalação de máquinas e } \\
\text { equipamentos }\end{array}$ & 937 & 117 & 427 & 392 & 70 & 33 & 834 & 88 & 605 & 244 & 264 & 295 & 378 \\
\hline
\end{tabular}

Fonte: IBGE (2016). Extrato da Tabela 1.1.13 da Pintec 2014. 
Tabela 3.9 - Empresas que implementaram inovações, por grau de importância do impacto causado, segundo atividades da indústria de transformação Brasil - 2014 (cont.)

\begin{tabular}{|c|c|c|c|c|c|c|c|c|c|c|c|c|c|}
\hline \multirow{4}{*}{ Atividades } & \multicolumn{13}{|c|}{ Empresas que implementaram inovações } \\
\hline & \multirow{3}{*}{ Total } & \multicolumn{12}{|c|}{ Impacto causado e grau de importância } \\
\hline & & \multicolumn{3}{|c|}{ Abertura de novos mercados } & \multicolumn{3}{|c|}{$\begin{array}{l}\text { Aumento da capacidade } \\
\text { produtiva }\end{array}$} & \multicolumn{3}{|c|}{$\begin{array}{l}\text { Aumento da flexibilidade da } \\
\text { produção }\end{array}$} & \multicolumn{3}{|c|}{ Redução dos custos de produção } \\
\hline & & Alta & Média & Baixa & Alta & Média & Baixa & Alta & Média & Baixa & Alta & Média & Baixa \\
\hline Indústria de transformação & 41.850 & 8.733 & 6.815 & 26.302 & 19.236 & 11.546 & 11.068 & 16.097 & 14.160 & 11.593 & 11171 & 13.239 & 17.440 \\
\hline Fabricação de produtos alimentícios & 6.168 & 1.275 & 993 & 3.900 & 2.773 & 1.977 & 1.418 & 2.348 & 2.188 & 1.633 & 1.568 & 1.509 & 3.091 \\
\hline Fabricação de bebidas & 423 & 33 & 101 & 289 & 189 & 78 & 156 & 211 & 58 & 155 & 199 & 72 & 151 \\
\hline Fabricação de produtos do fumo & 24 & - & 12 & 12 & 5 & 14 & 5 & 5 & 16 & 3 & 4 & 13 & 7 \\
\hline Fabricação de produtos têxteis & 1.234 & 235 & 106 & 893 & 585 & 315 & 334 & 381 & 254 & 599 & 286 & 350 & 598 \\
\hline Confecção de artigos do vestuário e acessórios & 5.107 & 459 & 918 & 3.730 & 1.870 & 1.475 & 1.761 & 1.999 & 1.591 & 1.517 & 1.396 & 1.433 & 2.277 \\
\hline Preparação de couros e fabricação de artefatos & 1.415 & 475 & 112 & 828 & 697 & 295 & 423 & 644 & 369 & 402 & 370 & 356 & 689 \\
\hline Fabricação de produtos de madeira & 1.325 & 124 & 455 & 745 & 805 & 455 & 64 & 743 & 479 & 103 & 240 & 631 & 454 \\
\hline Fabricação de celulose, papel e produtos de papel & 647 & 161 & 56 & 430 & 304 & 153 & 190 & 357 & 108 & 182 & 322 & 97 & 228 \\
\hline Impressão e reprodução de gravações & 839 & 101 & 21 & 716 & 455 & 193 & 191 & 444 & 265 & 129 & 267 & 344 & 228 \\
\hline $\begin{array}{l}\text { Fabricação de coque, de produtos derivados do } \\
\text { petróleo e de combustíveis }\end{array}$ & 125 & 25 & 16 & 83 & 48 & 26 & 51 & 32 & 26 & 66 & 21 & 27 & 77 \\
\hline Fabricação de produtos químicos & 1.802 & 588 & 381 & 833 & 786 & 319 & 696 & 580 & 604 & 617 & 492 & 501 & 808 \\
\hline $\begin{array}{l}\text { Fabricação de produtos farmoquímicos } \\
\text { farmacêticos }\end{array}$ & 212 & 42 & 26 & 144 & 74 & 74 & 64 & 60 & 75 & 77 & 70 & 37 & 105 \\
\hline Fabricação de artigos de borracha e plástico & 2.925 & 498 & 675 & 1.753 & 1.332 & 921 & 671 & 791 & 1.324 & 810 & 542 & 889 & 1.493 \\
\hline Fabricação de produtos de minerais não-metálicos & 4.229 & 755 & 471 & 3.003 & 1.956 & 1.132 & 1.141 & 1.460 & 1.679 & 1.090 & 1.184 & 1.489 & 1.556 \\
\hline Metalurgia & 669 & 94 & 92 & 482 & 294 & 182 & 193 & 228 & 339 & 102 & 180 & 350 & 139 \\
\hline Fabricação de produtos de metal & 3.513 & 784 & 368 & 2361 & 1963 & 877 & 673 & 1.695 & 1.111 & 707 & 951 & 1305 & 1.257 \\
\hline $\begin{array}{l}\text { Fabricação de equipamentos de informática, } \\
\text { produtos eletrônicos e ópticos }\end{array}$ & 1.053 & 448 & 196 & 409 & 404 & 337 & 312 & 370 & 297 & 386 & 278 & 347 & 427 \\
\hline $\begin{array}{l}\text { Fabricação de máquinas, aparelhos e materiais } \\
\text { elétricos }\end{array}$ & 1.022 & 249 & 244 & 529 & 451 & 273 & 298 & 400 & 241 & 381 & 370 & 220 & 432 \\
\hline Fabricação de máquinas e equipamentos & 2.657 & 148 & 74 & 125 & 162 & 99 & 86 & 136 & 105 & 106 & 84 & 105 & 159 \\
\hline $\begin{array}{l}\text { Fabricação de veículos automotores, reboques e } \\
\text { carrocerias }\end{array}$ & 1.080 & 620 & 599 & 1.438 & 1.179 & 885 & 593 & 963 & 854 & 840 & 602 & 1.217 & 838 \\
\hline Fabricação de outros equipamentos de transporte & 227 & 305 & 266 & 509 & 455 & 223 & 402 & 407 & 375 & 298 & 197 & 483 & 400 \\
\hline Fabricação de móveis & 2.714 & 71 & 59 & 97 & 103 & 45 & 79 & 107 & 63 & 57 & 73 & 56 & 97 \\
\hline Fabricação de produtos diversos & 1.504 & 838 & 147 & 1.730 & 1270 & 863 & 581 & 1.101 & 1.027 & 586 & 791 & 976 & 947 \\
\hline $\begin{array}{l}\text { Manutenção/instalação de máquinas e } \\
\text { equipamentos }\end{array}$ & 937 & 33 & 194 & 710 & 323 & 190 & 424 & 114 & 408 & 416 & 152 & 123 & 662 \\
\hline
\end{tabular}

Fonte: IBGE (2016). Extrato da Tabela 1.1.13 da Pintec 2014. 
Tabela 3.9 - Empresas que implementaram inovações, por grau de importância do impacto causado, segundo atividades da indústria de transformação Brasil - 2014 (cont.)

\begin{tabular}{|c|c|c|c|c|c|c|c|c|c|c|c|c|c|}
\hline \multirow{4}{*}{ Atividades } & \multicolumn{13}{|c|}{ Empresas que implementaram inovações } \\
\hline & \multirow{3}{*}{ Total } & \multicolumn{12}{|c|}{ Impacto causado e grau de importância } \\
\hline & & \multicolumn{3}{|c|}{$\begin{array}{l}\text { Redução dos custos do } \\
\text { trabalho }\end{array}$} & \multicolumn{3}{|c|}{$\begin{array}{l}\text { Redução do consumo de } \\
\text { matéria-prima }\end{array}$} & \multicolumn{3}{|c|}{ Redução do consumo de energia } & \multicolumn{3}{|c|}{ Redução do consumo de água } \\
\hline & & Alta & Média & Baixa & Alta & Média & Baixa & Alta & Média & Baixa & Alta & Média & Baixa \\
\hline Indústria de transformação & 41.850 & 10.524 & 13.416 & 17.910 & 5.408 & 8.934 & 27.507 & 3.805 & 8.174 & 29.871 & 3.170 & 4.922 & 33.758 \\
\hline Fabricação de produtos alimentícios & 6.168 & 1.509 & 1.457 & 3.202 & 552 & 1.201 & 4.415 & 231 & 956 & 4.982 & 253 & 1.252 & 4.663 \\
\hline Fabricação de bebidas & 423 & 171 & 103 & 149 & 126 & 62 & 236 & 145 & 28 & 249 & 148 & 40 & 235 \\
\hline Fabricação de produtos do fumo & 24 & 3 & 12 & 9 & 2 & 11 & 11 & - & 7 & 17 & & 4 & 20 \\
\hline Fabricação de produtos têxteis & 1.234 & 239 & 434 & 562 & 95 & 112 & 1027 & 103 & 218 & 914 & 160 & 128 & 947 \\
\hline Confecção de artigos do vestuário e acessórios & 5.107 & 1.335 & 1.480 & 2.292 & 799 & 1.418 & 2.889 & 233 & 845 & 4.028 & 270 & 301 & 4.535 \\
\hline Preparação de couros e fabricação de artefatos & 1.415 & 300 & 400 & 715 & 201 & 175 & 1.039 & 42 & 302 & 1.071 & 44 & 237 & 1.135 \\
\hline Fabricação de produtos de madeira & 1.325 & 247 & 734 & 344 & 64 & 642 & 618 & 21 & 500 & 803 & 72 & 153 & 1099 \\
\hline Fabricação de celulose, papel e produtos de papel & 647 & 304 & 103 & 240 & 34 & 62 & 551 & 76 & 69 & 502 & 89 & 25 & 533 \\
\hline Impressão e reprodução de gravações & 839 & 264 & 271 & 304 & 275 & 64 & 499 & 164 & 219 & 457 & 275 & 19 & 545 \\
\hline $\begin{array}{l}\text { Fabricação de coque, de produtos derivados do } \\
\text { petróleo e de combustiveis }\end{array}$ & 125 & 19 & 36 & 70 & 14 & 28 & 82 & 13 & 24 & 88 & 16 & 19 & 89 \\
\hline Fabricação de produtos químicos & 1.802 & 449 & 442 & 911 & 130 & 317 & 1.354 & 196 & 316 & 1.290 & 250 & 287 & 1.264 \\
\hline Fabricação de produtos farmoquímicos $\mathrm{e}$ & & & & & & & & & & & & & \\
\hline farmacêuticos & 212 & 64 & 35 & 113 & 25 & 24 & 163 & 33 & 37 & 142 & 24 & 21 & 167 \\
\hline Fabricação de artigos de borracha e plástico & 2.925 & 647 & 852 & 1.425 & 351 & 376 & 2.198 & 289 & 412 & 2.224 & 236 & 336 & 2.353 \\
\hline Fabricação de produtos de minerais não-metálicos & 4.229 & 1.192 & 1.731 & 1.306 & 732 & 1.006 & 2.491 & 713 & 797 & 2.720 & 373 & 537 & 3.319 \\
\hline Metalurgia & 669 & 106 & 361 & 201 & 36 & 160 & 473 & 41 & 112 & 515 & 17 & 45 & 607 \\
\hline Fabricação de produtos de metal & 3.513 & 919 & 1.100 & 1.494 & 500 & 721 & 2.292 & 416 & 608 & 2.489 & 130 & 305 & 3.078 \\
\hline $\begin{array}{l}\text { Fabricação de equipamentos de informática, } \\
\text { produtos eletrônicos e ópticos }\end{array}$ & 1.053 & 282 & 246 & 525 & 142 & 93 & 818 & 208 & 58 & 786 & 138 & 82 & 832 \\
\hline $\begin{array}{l}\text { Fabricação de máquinas, aparelhos e materiais } \\
\text { elétricos }\end{array}$ & 1.022 & 285 & 253 & 485 & 107 & 275 & 640 & 82 & 255 & 685 & 74 & 99 & 848 \\
\hline Fabricação de máquinas e equipamentos & 2.657 & 72 & 105 & 170 & 41 & 97 & 210 & 26 & 82 & 240 & 13 & 67 & 268 \\
\hline $\begin{array}{l}\text { Fabricação de veículos automotores, reboques e } \\
\text { carrocerias }\end{array}$ & 1.080 & 542 & 1.118 & 997 & 161 & 693 & 1.803 & 224 & 621 & 1.812 & 276 & 273 & 2.109 \\
\hline Fabricação de outros equipamentos de transporte & 227 & 271 & 402 & 407 & 175 & 295 & 611 & 143 & 340 & 598 & 146 & 163 & 771 \\
\hline Fabricação de móveis & 2.714 & 52 & 75 & 99 & 43 & 61 & 123 & 30 & 57 & 141 & 12 & 20 & 195 \\
\hline Fabricação de produtos diversos & 1.504 & 710 & 1.029 & 975 & 419 & 636 & 1.660 & 158 & 963 & 1.593 & 114 & 321 & 2.279 \\
\hline $\begin{array}{l}\text { Manutenção/instalação de máquinas e } \\
\text { equipamentos }\end{array}$ & 937 & 189 & 373 & 374 & 18 & 207 & 712 & 19 & 141 & 777 & 3 & 10 & 923 \\
\hline
\end{tabular}

Fonte: IBGE (2016). Extrato da Tabela 1.1.13 da Pintec 2014. 
Tabela 3.9 - Empresas que implementaram inovações, por grau de importância do impacto causado, segundo atividades da indústria de transformação Brasil - 2014 (cont.)

\begin{tabular}{|c|c|c|c|c|c|c|c|c|c|c|c|c|c|}
\hline \multirow{4}{*}{ Atividades } & \multicolumn{13}{|c|}{ Empresas que implementaram inovações } \\
\hline & \multirow{3}{*}{ Total } & \multicolumn{12}{|c|}{ Impacto causado e grau de importância } \\
\hline & & \multicolumn{3}{|c|}{$\begin{array}{l}\text { Redução do impacto } \\
\text { ambiental e/ou em aspectos } \\
\text { ligados à saúde e segurança }\end{array}$} & \multicolumn{3}{|c|}{ Redução do impacto ambiental } & \multicolumn{3}{|c|}{$\begin{array}{l}\text { Ampliação do controle de } \\
\text { aspectos ligados à saúde e } \\
\text { segurança }\end{array}$} & \multicolumn{3}{|c|}{$\begin{array}{l}\text { Enquadramento em regulações } \mathrm{e} \\
\text { normas }\end{array}$} \\
\hline & & Alta & Média & Baixa & Alta & Média & Baixa & Alta & Média & Baixa & Alta & Média & Baixa \\
\hline Indústria de transformação & 41.850 & 17.174 & 13.459 & 26.509 & 10.425 & 6.919 & 24.505 & 14.744 & 10.300 & 16.806 & 12.090 & 9.392 & 20.368 \\
\hline Fabricação de produtos alimentícios & 6.168 & 2.597 & 1.995 & 4.301 & 993 & 1.127 & 4.048 & 2.459 & 1.468 & 2.241 & 2.197 & 1.423 & 2.549 \\
\hline Fabricação de bebidas & 423 & 230 & 117 & 198 & 169 & 64 & 189 & 222 & 75 & 127 & 202 & 51 & 170 \\
\hline Fabricação de produtos do fumo & 24 & 4 & 8 & 16 & 2 & 6 & 16 & 3 & 8 & 13 & 3 & 6 & 15 \\
\hline Fabricação de produtos têxteis & 1.234 & 432 & 365 & 799 & 305 & 278 & 651 & 268 & 292 & 674 & 355 & 340 & 540 \\
\hline Confecção de artigos do vestuário e acessórios & 5.107 & 1.303 & 1.437 & 3.982 & 860 & 611 & 3.635 & 892 & 1.128 & 3.087 & 646 & 1.170 & 3.290 \\
\hline Preparação de couros e fabricação de artefatos & 1.415 & 772 & 293 & 858 & 430 & 206 & 779 & 678 & 242 & 495 & 450 & 366 & 599 \\
\hline Fabricação de produtos de madeira & 1.325 & 834 & 438 & 672 & 583 & 137 & 604 & 734 & 410 & 180 & 337 & 250 & 738 \\
\hline Fabricação de celulose, papel e produtos de papel & 647 & 157 & 195 & 502 & 121 & 52 & 474 & 136 & 166 & 345 & 133 & 72 & 441 \\
\hline Impressão e reprodução de gravações & 839 & 512 & 90 & 476 & 412 & 29 & 398 & 425 & 83 & 331 & 370 & 102 & 368 \\
\hline $\begin{array}{l}\text { Fabricação de coque, de produtos derivados do } \\
\text { petróleo e de combustiveis }\end{array}$ & 125 & 61 & 37 & 69 & 34 & 30 & 61 & 59 & 24 & 42 & 42 & 25 & 58 \\
\hline Fabricação de produtos químicos & 1.802 & 785 & 626 & 1026 & 612 & 306 & 884 & 511 & 474 & 818 & 728 & 368 & 706 \\
\hline $\begin{array}{l}\text { Fabricação de produtos farmoquímicos } \\
\text { farmacêuticos }\end{array}$ & 212 & 63 & 103 & 107 & 35 & 72 & 105 & 57 & 93 & 61 & 117 & 37 & 58 \\
\hline Fabricação de artigos de borracha e plástico & 2.925 & 945 & 828 & 1.977 & 691 & 459 & 1.774 & 734 & 687 & 1.504 & 715 & 555 & 1.655 \\
\hline Fabricação de prod.de minerais não-metálicos & 4.229 & 2.412 & 1.367 & 1.736 & 1.728 & 851 & 1.650 & 2.208 & 946 & 1.076 & 1.430 & 1.197 & 1.602 \\
\hline Metalurgia & 669 & 380 & 218 & 373 & 204 & 108 & 357 & 360 & 174 & 135 & 178 & 222 & 268 \\
\hline Fabricação de produtos de metal & 3.513 & 1.218 & 1.295 & 2.465 & 694 & 500 & 2.319 & 1.136 & 1.048 & 1.329 & 822 & 807 & 1.884 \\
\hline $\begin{array}{l}\text { Fabricação de equipamentos de informática, } \\
\text { produtos eletrônicos e ópticos }\end{array}$ & 1.053 & 443 & 259 & 720 & 226 & 139 & 688 & 420 & 161 & 472 & 425 & 206 & 421 \\
\hline $\begin{array}{l}\text { Fabricação de máquinas, aparelhos e materiais } \\
\text { elétricos }\end{array}$ & 1.022 & 366 & 229 & 685 & 301 & 107 & 615 & 303 & 163 & 556 & 276 & 348 & 398 \\
\hline Fabricação de máquinas e equipamentos & 2.657 & 133 & 118 & 218 & 98 & 61 & 188 & 105 & 85 & 158 & 106 & 99 & 143 \\
\hline $\begin{array}{l}\text { Fabricação de veículos automotores, reboques e } \\
\text { carrocerias }\end{array}$ & 1.080 & 894 & 996 & 1.790 & 460 & 476 & 1.721 & 799 & 709 & 1.149 & 705 & 517 & 1.435 \\
\hline Fabricação de outros equipamentos de transporte & 227 & 480 & 413 & 653 & 392 & 126 & 562 & 257 & 355 & 469 & 220 & 196 & 665 \\
\hline Fabricação de móveis & 2.714 & 117 & 66 & 126 & 91 & 25 & 111 & 79 & 50 & 97 & 76 & 57 & 93 \\
\hline Fabricação de produtos diversos & 1.504 & 1.183 & 1.412 & 1.286 & 655 & 869 & 1.190 & 1.045 & 1.139 & 530 & 983 & 768 & 964 \\
\hline Manutenção/instalação de máq. e equipamentos & 937 & 278 & 336 & 695 & 145 & 100 & 692 & 269 & 244 & 424 & 48 & 216 & 673 \\
\hline
\end{tabular}

Fonte: IBGE (2016). Extrato da Tabela 1.1.13 da Pintec 2014. 
$\mathrm{Na}$ tabela 3.9, percebe-se que as principais atividades da indústria de transformação que atribuíram um grau de importância aos impactos gerados pela implementação de inovações foram as empresas de fabricação de produtos alimentícios, as de confecção de artigos do vestuário e acessórios e fabricação de produtos de minerais não-metálicos.

Fazendo-se um recorte dessas três atividades da indústria de transformação, descobre-se que foi atribuído alto impacto, considerando-se a média do percentual obtido, para redução dos custos do trabalho, redução do consumo de matéria-prima e ampliação do controle de aspectos ligados à saúde e segurança, todos com percentual médio de 13\%. Quanto ao grau de impacto médio, utilizando-se o mesmo cálculo anterior, verificou-se que os principais impactos são: redução do consumo de matéria-prima e redução do consumo de água, ambos com 14\%.

Com relação ao grau de impacto baixo, sob mesma avaliação dos anteriores, verificou-se que os principais impactos apontados na pesquisa foram: manutenção da participação da empresa no mercado (15\%) e ampliação da participação da empresa no mercado (14\%).

Buscou-se neste capítulo apresentar um panorama geral da indústria brasileira de transformação no Brasil e caracterizar como as empresas que geraram inovações no período 2012-2014 (inovações de produto e/ou processo ou com projetos de inovação) se situam neste panorama. Considera-se que os dados apresentados sobre o envolvimento dessas empresas em arranjos cooperativos com outras organizações na perspectiva de inovar e os impactos das inovações que geram em diferentes dimensões (mercado; produção; ambiental; social; e regulatória) fornecerão importantes subsídios para a discussão dos resultados do estudo empírico objeto do capítulo 4, a seguir. 


\section{4 \\ Estudo empírico: cooperação interorganizacional e apropriação de valor das inovações geradas pelas empresas da indústria de transformação no Brasil}

Neste capítulo, apresentam-se e discutem-se os resultados do estudo empírico sobre a influência de diferentes parceiros na apropriação de valor das inovações geradas em arranjos cooperativos formados pelas empresas da indústria de transformação no Brasil com outras organizações. Para tal, consideram-se condições ambientais distintas, como nível de intensidade tecnológica e força do regime de apropriabilidade dos setores em que atuam, e diferentes características internas, como o tamanho das empresas e a capacidade de cooperar em projetos de PD\&I. Como fonte de dados secundários, utilizaram-se microdados da Pintec 2014, conduzida pelo Instituto Brasileiro de Geografia e Estatística (IBGE), junto a 1.520 empresas inovadoras desta indústria envolvidas em arranjos cooperativos com outras organizações no período de 2012 a 2014, que responderam à Pintec 2014.

\section{1. \\ Definição dos objetivos do estudo}

O objetivo geral do estudo é analisar e comparar a influência de diferentes parceiros em arranjos de cooperação interorganizacional sobre a apropriação de valor das inovações geradas pelas empresas da indústria de transformação no Brasil, considerando-se características ambientais distintas, como nível de intensidade tecnológica e força do regime de apropriabilidade dos setores em que atuam, bem como características internas, como tamanho da empresa (micro e pequenas; médias; e grandes empresas) e capacidade para inovar em arranjos cooperativos focalizando projetos de PD\&I para inovações de produto e/ou processo.

Para atingir este objetivo geral, definiram-se os seguintes objetivos específicos:

- Caracterizar os principais parceiros das empresas da indústria de 
transformação brasileira que podem influenciar a apropriação de valor das inovações geradas em arranjos cooperativos para projetos de PD\&I em cada uma das dimensões de impactos dessas inovações (produto e/ou processo);

- Identificar e descrever o papel da cooperação interorganizacional na apropriação de valor pelas empresas brasileiras da indústria de transformação que cooperaram com outras organizações e inovaram;

- Analisar e comparar os resultados dos modelos de regressão logística referentes aos agrupamentos setoriais da amostra (setores AT/FO/ AT/FR; BT/FO; BT/FR);

- Analisar e comparar os resultados dos modelos de regressão logística referentes aos agrupamentos acima, considerando-se o tamanho das empresas em cada agrupamento (micro e pequenas; médias; e grandes empresas).

Deste modo, pretende-se investigar como se relacionam os fenômenos da cooperação interorganizacional e apropriação de valor no âmbito das empresas da indústria de transformação no Brasil no período de 2012 a 2014, considerando-se características ambientais distintas, como nível de intensidade tecnológica e força do regime de apropriabilidade dos setores em que atuam, bem como características internas, como tamanho da empresa (micro e pequenas; médias; e grandes empresas) e capacidade para inovar em arranjos cooperativos focalizando projetos de PD\&I para inovações de produto e/ou processo.

\section{2.}

\section{Hipóteses de pesquisa}

A formulação das hipóteses de pesquisa considerou a revisão da literatura apresentada no capítulo 2, alinhando-se aos objetivos propostos no item 4.1, bem como o modelo conceitual representado e descrito no final do capítulo 2 e a estrutura lógica do questionário da fonte de dados - a Pintec 2014.

As hipóteses de pesquisa apresentadas no quadro 4.1 foram formuladas tendo em vista a variável dependente - apropriação de valor pelas inovações geradas em arranjos cooperativos formados pelas empresas da indústria de transformação no Brasil. Em função das questões da Pintec 2014, a variável dependente será desdobrada na fase de modelagem em cinco dimensões de 
impactos das inovações de produto e/ou processo, a saber: (i) mercadológicos; (ii) na produção; (iii) ambientais; (iv) sociais; e (v) regulatórios.

Quadro 4.1 - Síntese das hipóteses associadas à influência da cooperação interorganizacional na apropriação de valor das inovações geradas pelas empresas de transformação no Brasil

\begin{tabular}{|c|c|c|}
\hline Hipóteses & $\begin{array}{l}\text { Variáveis } \\
\text { explanatórias }\end{array}$ & $\begin{array}{l}\text { Variáveis } \\
\text { dependentes }\end{array}$ \\
\hline $\begin{array}{l}\text { H1: a cooperação com clientes e consumidores } \\
\text { influencia positivamente a apropriação de valor pela } \\
\text { empresa }\end{array}$ & \multirow{6}{*}{$\begin{array}{l}\text { Importância de } \\
\text { clientes e } \\
\text { consumidores como } \\
\text { parceiros em } \\
\text { arranjos } \\
\text { cooperativos para } \\
\text { projetos de PD\&l }\end{array}$} & \multirow{18}{*}{$\begin{array}{l}\text { Apropriação de } \\
\text { valor pelas } \\
\text { inovações geradas } \\
\text { em arranjos } \\
\text { cooperativos, } \\
\text { expressa por seus } \\
\text { impactos: } \\
\text { - Mercadológicos; } \\
\text { - Na produção; } \\
\text { - Ambientais; } \\
\text { - Sociais; } \\
\text { - Regulatórios. }\end{array}$} \\
\hline $\begin{array}{l}\text { H1.1: a cooperação com clientes e consumidores influencia } \\
\text { positivamente a apropriação de valor das inovações geradas } \\
\text { em arranjos cooperativos, pelos seus impactos } \\
\text { mercadológicos. }\end{array}$ & & \\
\hline $\begin{array}{l}\text { H1.2: a cooperação com clientes e consumidores influencia } \\
\text { positivamente a apropriação de valor das inovações geradas } \\
\text { em arranjos cooperativos, pelos seus impactos na produção. }\end{array}$ & & \\
\hline $\begin{array}{l}\text { H1.3: a cooperação com clientes e consumidores influencia } \\
\text { positivamente a apropriação de valor das inovações geradas } \\
\text { em arranjos cooperativos, pelos seus impactos ambientais. }\end{array}$ & & \\
\hline $\begin{array}{l}\text { H1.4: a cooperação com clientes e consumidores influencia } \\
\text { positivamente a apropriação de valor das inovações geradas } \\
\text { em arranjos cooperativos, pelos seus impactos sociais. }\end{array}$ & & \\
\hline $\begin{array}{l}\text { H1.5: a cooperação com clientes e consumidores influencia } \\
\text { positivamente a apropriação de valor das inovações geradas } \\
\text { em arranjos cooperativos, pelos seus impactos regulatórios. }\end{array}$ & & \\
\hline $\begin{array}{l}\text { H2: a cooperação com fornecedores influencia } \\
\text { positivamente a apropriação de valor pela empresa }\end{array}$ & \multirow{6}{*}{$\begin{array}{l}\text { Importância de } \\
\text { fornecedores como } \\
\text { parceiros em } \\
\text { arranjos } \\
\text { cooperativos para } \\
\text { projetos de PD\&l }\end{array}$} & \\
\hline $\begin{array}{l}\text { H2.1: a cooperação com fornecedores influencia } \\
\text { positivamente a apropriação de valor das inovações geradas } \\
\text { em arranjos cooperativos, pelos seus impactos } \\
\text { mercadológicos. }\end{array}$ & & \\
\hline $\begin{array}{l}\text { H2.2: a cooperação com fornecedores influencia } \\
\text { positivamente a apropriação de valor das inovações geradas } \\
\text { em arranjos cooperativos, pelos seus impactos na produção. }\end{array}$ & & \\
\hline $\begin{array}{l}\text { H2.3: a cooperação com fornecedores influencia } \\
\text { positivamente a apropriação de valor das inovações geradas } \\
\text { em arranjos cooperativos, pelos seus impactos ambientais. }\end{array}$ & & \\
\hline $\begin{array}{l}\text { H2.4: a cooperação com fornecedores influencia } \\
\text { positivamente a apropriação de valor das inovações geradas } \\
\text { em arranjos cooperativos, pelos seus impactos sociais. }\end{array}$ & & \\
\hline $\begin{array}{l}\text { H2.5: a cooperação com fornecedores influencia } \\
\text { positivamente a apropriação de valor das inovações geradas } \\
\text { em arranjos cooperativos, pelos seus impactos regulatórios. }\end{array}$ & & \\
\hline $\begin{array}{l}\text { H3: a cooperação com concorrentes influencia } \\
\text { positivamente a apropriação de valor pela empresa }\end{array}$ & \multirow{6}{*}{$\begin{array}{l}\text { Importância de } \\
\text { concorrentes como } \\
\text { parceiros em } \\
\text { arranjos } \\
\text { cooperativos para } \\
\text { projetos de PD\&l }\end{array}$} & \\
\hline $\begin{array}{l}\text { H3.1: a cooperação com concorrentes influencia } \\
\text { positivamente a apropriação de valor das inovações geradas } \\
\text { em arranjos cooperativos, pelos seus impactos } \\
\text { mercadológicos. }\end{array}$ & & \\
\hline $\begin{array}{l}\text { H3.2: a cooperação com concorrentes influencia } \\
\text { positivamente a apropriação de valor das inovações geradas } \\
\text { em arranjos cooperativos, pelos seus impactos na produção. }\end{array}$ & & \\
\hline $\begin{array}{l}\text { H3.3: a cooperação com concorrentes influencia } \\
\text { positivamente a apropriação de valor das inovações geradas } \\
\text { em arranjos cooperativos, pelos seus impactos ambientais. }\end{array}$ & & \\
\hline $\begin{array}{l}\text { H3.4: a cooperação com concorrentes influencia } \\
\text { positivamente a apropriação de valor das inovações geradas } \\
\text { em arranjos cooperativos, pelos seus impactos sociais. }\end{array}$ & & \\
\hline $\begin{array}{l}\text { H3.5: a cooperação com concorrentes influencia } \\
\text { positivamente a apropriação de valor das inovações geradas } \\
\text { em arranjos cooperativos, pelos seus impactos regulatórios. }\end{array}$ & & \\
\hline
\end{tabular}


Quadro 4.1 - Síntese das hipóteses associadas à influência da cooperação interorganizacional na apropriação de valor das inovações geradas pelas empresas de transformação no Brasil (cont.)

\begin{tabular}{|c|c|c|}
\hline Hipóteses & $\begin{array}{l}\text { Variáveis } \\
\text { explanatórias }\end{array}$ & $\begin{array}{l}\text { Variáveis } \\
\text { dependentes }\end{array}$ \\
\hline $\begin{array}{l}\text { H4: a cooperação com outra empresa do grupo } \\
\text { influencia positivamente a apropriação de valor pela } \\
\text { empresa }\end{array}$ & \multirow{6}{*}{$\begin{array}{l}\text { Importância de outra } \\
\text { empresa do grupo } \\
\text { como parceira em } \\
\text { arranjos } \\
\text { cooperativos para } \\
\text { projetos de PD\&I }\end{array}$} & \multirow{18}{*}{$\begin{array}{l}\text { Apropriação de } \\
\text { valor pelas } \\
\text { inovações geradas } \\
\text { em arranjos } \\
\text { cooperativos, } \\
\text { expressa por seus } \\
\text { impactos: } \\
\text { - Mercadológicos; } \\
\text { - Na produção; } \\
\text { - Ambientais; } \\
\text { - Sociais; } \\
\text { - Regulatórios. }\end{array}$} \\
\hline $\begin{array}{l}\text { H4.1: a cooperação com outra empresa do grupo influencia } \\
\text { positivamente a apropriação de valor das inovações geradas } \\
\text { em arranjos cooperativos, pelos seus impactos } \\
\text { mercadológicos. }\end{array}$ & & \\
\hline $\begin{array}{l}\text { H4.2: a cooperação com outra empresa do grupo influencia } \\
\text { positivamente a apropriação de valor das inovações geradas } \\
\text { em arranjos cooperativos, pelos seus impactos na produção. }\end{array}$ & & \\
\hline $\begin{array}{l}\text { H4.3: a cooperação com outra empresa do grupo influencia } \\
\text { positivamente a apropriação de valor das inovações geradas } \\
\text { em arranjos cooperativos, pelos seus impactos ambientais. }\end{array}$ & & \\
\hline $\begin{array}{l}\text { H4.4: a cooperação com outra empresa do grupo influencia } \\
\text { positivamente a apropriação de valor das inovações geradas } \\
\text { em arranjos cooperativos, pelos seus impactos sociais. }\end{array}$ & & \\
\hline $\begin{array}{l}\text { H4.5: a cooperação com outra empresa do grupo influencia } \\
\text { positivamente a apropriação de valor das inovações geradas } \\
\text { em arranjos cooperativos, pelos seus impactos regulatórios. }\end{array}$ & & \\
\hline $\begin{array}{l}\text { H5: a cooperação com empresas de consultoria } \\
\text { influencia positivamente a apropriação de valor pela } \\
\text { empresa }\end{array}$ & \multirow{6}{*}{$\begin{array}{l}\text { Importância de } \\
\text { empresas de } \\
\text { consultoria como } \\
\text { parceiras em } \\
\text { arranjos } \\
\text { cooperativos para } \\
\text { projetos de PD\&I }\end{array}$} & \\
\hline $\begin{array}{l}\text { H5.1: a cooperação com empresas de consultoria influencia } \\
\text { positivamente a apropriação de valor das inovações geradas } \\
\text { em arranjos cooperativos, pelos seus impactos } \\
\text { mercadológicos. }\end{array}$ & & \\
\hline $\begin{array}{l}\text { H5.2: a cooperação com empresas de consultoria influencia } \\
\text { positivamente a apropriação de valor das inovações geradas } \\
\text { em arranjos cooperativos, pelos seus impactos na produção. }\end{array}$ & & \\
\hline $\begin{array}{l}\text { H5.3: a cooperação com empresas de consultoria influencia } \\
\text { positivamente a apropriação de valor das inovações geradas } \\
\text { em arranjos cooperativos, pelos seus impactos ambientais. }\end{array}$ & & \\
\hline $\begin{array}{l}\text { H5.4: a cooperação com empresas de consultoria influencia } \\
\text { positivamente a apropriação de valor das inovações geradas } \\
\text { em arranjos cooperativos, pelos seus impactos sociais. }\end{array}$ & & \\
\hline $\begin{array}{l}\text { H5.5: a cooperação com empresas de consultoria influencia } \\
\text { positivamente a apropriação de valor das inovações geradas } \\
\text { em arranjos cooperativos, pelos seus impactos regulatórios. }\end{array}$ & & \\
\hline $\begin{array}{l}\text { H6: a cooperação com universidades ou institutos de } \\
\text { pesquisa influencia positivamente a apropriação de } \\
\text { valor pela empresa. }\end{array}$ & \multirow{6}{*}{$\begin{array}{l}\text { Importância de } \\
\text { universidades ou } \\
\text { institutos de } \\
\text { pesquisa como } \\
\text { parceiros em } \\
\text { arranjos } \\
\text { cooperativos para } \\
\text { projetos de PD\&l }\end{array}$} & \\
\hline $\begin{array}{l}\text { H6.1: a cooperação com universidades ou institutos de } \\
\text { pesquisa influencia positivamente a apropriação de valor das } \\
\text { inovações geradas em arranjos cooperativos, pelos seus } \\
\text { impactos mercadológicos. }\end{array}$ & & \\
\hline $\begin{array}{l}\text { H6.2: a cooperação com universidades ou institutos de } \\
\text { pesquisa influencia positivamente a apropriação de valor das } \\
\text { inovações geradas em arranjos cooperativos, pelos seus } \\
\text { impactos na produção. }\end{array}$ & & \\
\hline $\begin{array}{l}\text { H6.3: a cooperação com universidades ou institutos de } \\
\text { pesquisa influencia positivamente a apropriação de valor das } \\
\text { inovações geradas em arranjos cooperativos, pelos seus } \\
\text { impactos ambientais. }\end{array}$ & & \\
\hline $\begin{array}{l}\text { H6.4: a cooperação com universidades ou institutos de } \\
\text { pesquisa influencia positivamente a apropriação de valor das } \\
\text { inovações geradas em arranjos cooperativos, pelos seus } \\
\text { impactos sociais. }\end{array}$ & & \\
\hline $\begin{array}{l}\text { H6.5: a cooperação com universidades ou institutos de } \\
\text { pesquisa influencia a positivamente a apropriação de valor } \\
\text { das inovações geradas em arranjos cooperativos, pelos seus } \\
\text { impactos regulatórios. }\end{array}$ & & \\
\hline
\end{tabular}


Quadro 4.1 - Síntese das hipóteses associadas à influência da cooperação interorganizacional na apropriação de valor das inovações geradas pelas empresas de transformação no Brasil (cont.)

\begin{tabular}{|c|c|c|}
\hline Hipóteses & $\begin{array}{l}\text { Variáveis } \\
\text { explanatórias }\end{array}$ & $\begin{array}{l}\text { Variáveis } \\
\text { dependentes }\end{array}$ \\
\hline $\begin{array}{l}\text { H7: a cooperação com centros de capacitação } \\
\text { profissional e assistência técnica influencia } \\
\text { positivamente a apropriação de valor pela empresa. }\end{array}$ & \multirow{6}{*}{$\begin{array}{l}\text { Importância de } \\
\text { centros de } \\
\text { capacitação } \\
\text { profissional e } \\
\text { assistência técnica } \\
\text { como parceiros em } \\
\text { arranjos } \\
\text { cooperativos para } \\
\text { projetos de PD\&l }\end{array}$} & \multirow{12}{*}{$\begin{array}{l}\text { Apropriação de } \\
\text { valor pelas } \\
\text { inovações geradas } \\
\text { em arranjos } \\
\text { cooperativos, } \\
\text { expressa por seus } \\
\text { impactos: } \\
\text { - Mercadológicos; } \\
\text { - Na produção; } \\
\text { - Ambientais; } \\
\text { - Sociais; } \\
\text { - Regulatórios. }\end{array}$} \\
\hline $\begin{array}{l}\text { H7.1: a cooperação com centros de capacitação } \\
\text { profissional e assistência técnica influencia positivamente a } \\
\text { apropriação de valor das inovações geradas em arranjos } \\
\text { cooperativos, pelos seus impactos mercadológicos. }\end{array}$ & & \\
\hline $\begin{array}{l}\text { H7.2: a cooperação com centros de capacitação } \\
\text { profissional e assistência técnica influencia positivamente a } \\
\text { apropriação de valor das inovações geradas em arranjos } \\
\text { cooperativos, pelos seus impactos na produção. }\end{array}$ & & \\
\hline $\begin{array}{l}\text { H7.3: a cooperação com centros de capacitação } \\
\text { profissional e assistência técnica influencia positivamente a } \\
\text { apropriação de valor das inovações geradas em arranjos } \\
\text { cooperativos, pelos seus impactos ambientais. }\end{array}$ & & \\
\hline $\begin{array}{l}\text { H7.4: a cooperação com centros de capacitação } \\
\text { profissional e assistência técnica influencia positivamente a } \\
\text { apropriação de valor das inovações geradas em arranjos } \\
\text { cooperativos, pelos seus impactos sociais. }\end{array}$ & & \\
\hline $\begin{array}{l}\text { H7.5: a cooperação com centros de capacitação } \\
\text { profissional e assistência técnica influencia positivamente a } \\
\text { apropriação de valor das inovações geradas em arranjos } \\
\text { cooperativos, pelos seus impactos regulatórios. }\end{array}$ & & \\
\hline $\begin{array}{l}\text { H8: a cooperação com instituições de ensaios e } \\
\text { certificações influencia positivamente a apropriação } \\
\text { de valor pela empresa. }\end{array}$ & \multirow{6}{*}{$\begin{array}{l}\text { Importância de } \\
\text { instituições de } \\
\text { ensaios e } \\
\text { certificações como } \\
\text { parceiras em } \\
\text { arranjos } \\
\text { cooperativos para } \\
\text { projetos de PD\&I }\end{array}$} & \\
\hline $\begin{array}{l}\text { H8.1: a cooperação com instituições de ensaios e } \\
\text { certificações influencia positivamente a apropriação de valor } \\
\text { das inovações geradas em arranjos cooperativos, pelos } \\
\text { seus impactos mercadológicos. }\end{array}$ & & \\
\hline $\begin{array}{l}\text { H8.2: a cooperação com instituições de ensaios e } \\
\text { certificações influencia positivamente a apropriação de valor } \\
\text { das inovações geradas em arranjos cooperativos, pelos } \\
\text { seus impactos na produção. }\end{array}$ & & \\
\hline $\begin{array}{l}\text { H8.3: a cooperação com instituições de ensaios e } \\
\text { certificações influencia positivamente a apropriação de valor } \\
\text { das inovações geradas em arranjos cooperativos, pelos } \\
\text { seus impactos ambientais. }\end{array}$ & & \\
\hline $\begin{array}{l}\text { H8.4: a cooperação com instituições de ensaios e } \\
\text { certificações influencia positivamente a apropriação de valor } \\
\text { das inovações geradas em arranjos cooperativos, pelos } \\
\text { seus impactos sociais. }\end{array}$ & & \\
\hline $\begin{array}{l}\text { H8.5: a cooperação com instituições de ensaios e } \\
\text { certificações influencia positivamente a apropriação de valor } \\
\text { das inovações geradas em arranjos cooperativos, pelos } \\
\text { seus impactos regulatórios. }\end{array}$ & & \\
\hline
\end{tabular}

Fonte: Elaboração própria.

As hipóteses apresentadas no quadro 4.1 serão empiricamente testadas e analisadas pelo método de regressão logística, com base em microdados da Pintec 2014 e com emprego do pacote estatístico Statistical Analysis Software (SAS).

$\mathrm{Na}$ figura 4.1 encontra-se representado o modelo conceitual proposto no capítulo 2, porém incluindo as hipóteses de pesquisa definidas no quadro 4.1. 
Cada uma das hipóteses de pesquisa a serem testadas empiricamente será analisada no âmbito das cinco dimensões de impactos das inovações geradas em arranjos cooperativos, como representado na figura abaixo.

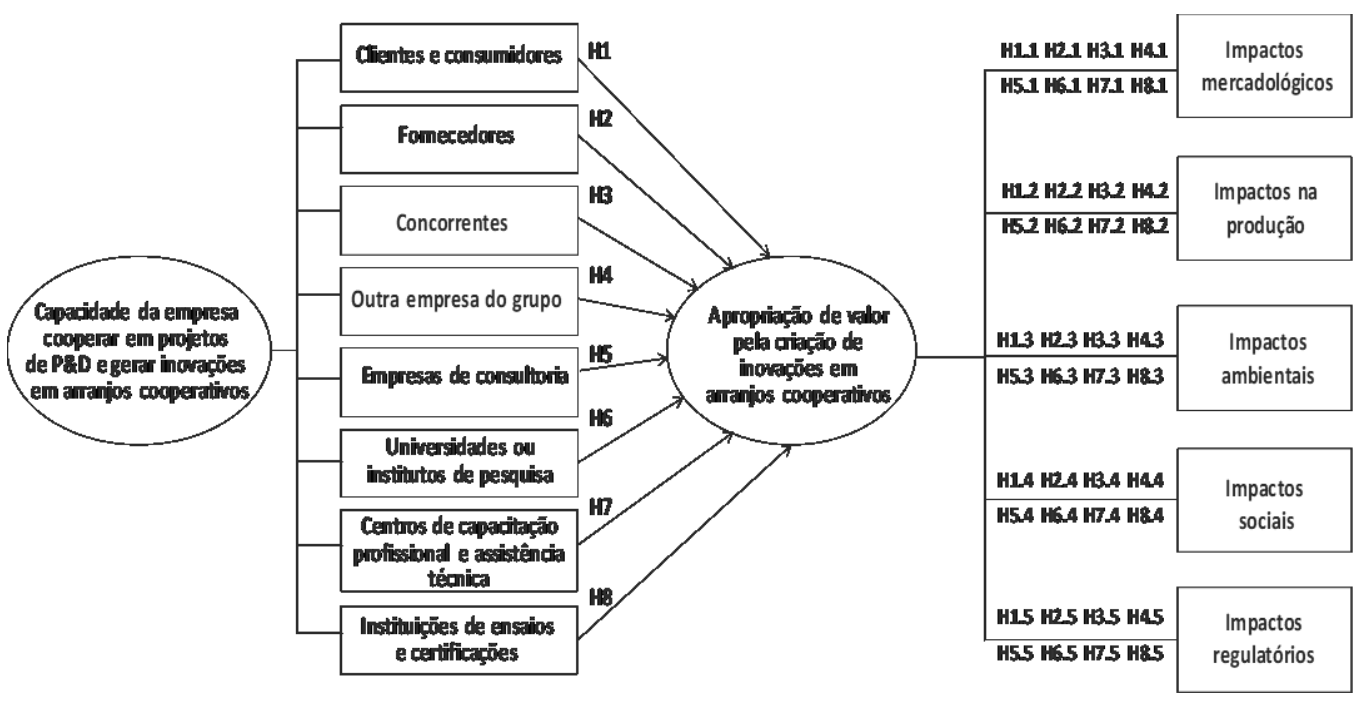

Figura 4.1 - Modelo conceitual proposto com as hipóteses de pesquisa Fonte: Elaboração própria.

Busca-se demonstrar empiricamente a influência de diferentes parceiros em arranjos de cooperação interorganizacional sobre a apropriação de valor das inovações geradas pelas empresas da indústria de transformação no Brasil, considerando-se características ambientais distintas, como nível de intensidade tecnológica e força do regime de apropriabilidade dos setores em que atuam, bem como características internas, como tamanho da empresa (micro e pequenas; médias; e grandes empresas) e capacidade para inovar em arranjos cooperativos focalizando projetos de PD\&I para inovações de produto e/ou processo.

\section{3.}

\section{Métodos adotados}

Inicialmente, levantam-se algumas questões que condicionaram a fase de modelagem. Em primeiro lugar, surgiu a questão associada à seleção da população objeto de estudo. Na presente pesquisa, consideraram-se os microdados da Pintec 2014 referentes às empresas da indústria de transformação no território nacional, que responderam à Pesquisa Nacional de Inovação referente ao período 20122014. 
Considerou-se ainda uma segunda questão associada ao método de coleta de dados, especialmente no que tange ao tipo de dados necessários e à forma de acesso a eles.

Finalmente surgiram as questões da modelagem propriamente dita, que requereram a identificação e análise dos métodos estatísticos mais apropriados e consistentes para realização das análises pretendidas neste estudo empírico.

Nesta seção, descrevem-se os métodos adotados para a coleta de dados, a construção da amostra do estudo empírico; a definição das variáveis, códigos e escalas de medidas adotadas; a escolha do método de regressão múltipla; e a modelagem de dados e inferência estatística.

\subsection{1.}

\section{Coleta de dados: Pintec 2014 como fonte de dados secundários}

A Pesquisa de Inovação Pintec tem por objetivo a construção de indicadores setoriais, nacionais e regionais, das atividades de inovação nas empresas do setor de indústria (extrativa e de transformação), e de indicadores nacionais das atividades de inovação nas empresas dos setores de eletricidade e gás e de serviços selecionados, compatíveis com as recomendações internacionais em termos conceituais e metodológicos.

Tendo como referência o período 2012-2014, a Pintec 2014 dá continuidade à série iniciada com a Pintec 2000, que levantou informações relativas ao triênio 1998-2000, seguida pelas pesquisas de 2003 (triênio 2001-2003), 2005 (triênio 2003-2005), 2008 (triênio 2006-2008) e 2011 (triênio 2009-2011).

A Pintec foi inspirada na experiência do modelo harmonizado proposto pelo EUROSTAT: a terceira e a quarta versão do Community Innovation Survey (CIS), que permite a comparação das informações com referências internacionalmente aceitas.

A unidade estatística e de análise é a empresa. Em empresas com mais de uma unidade local (endereço de atuação), identificam-se as atividades inovativas realizadas em todas as suas unidades locais e mensurado o seu impacto na empresa como um todo (IBGE, 2016).

Para o desenho da amostra, o IBGE utilizou o cadastro básico de seleção da amostra originado do Cadastro Central de Empresas - CEMPRE, delimitado pelo âmbito da pesquisa. Na Pintec 2014, o tamanho da amostra nas indústrias 
extrativas e de transformação foi fixado em 14.387 empresas, em 96 empresas no setor de eletricidade e gás, e em 2.688 nos serviços selecionados.

O IBGE realizou uma amostra estratificada desproporcional em três etapas: (i) identificação prévia das empresas que possuem maior probabilidade de serem inovadoras, para aumentar a fração amostral para este subconjunto ${ }^{4}$; (ii) divisão da população em três estratos: estrato certo (formado pelas empresas com $500 \mathrm{ou}$ mais empregados, que são incluídas com probabilidade um na amostra); estrato de empresas potencialmente inovadoras (composto por empresas com indicadores de probabilidade de serem inovadoras): e estrato de empresas sem indicação de potencial inovador (formado pelas empresas que não possuem nenhum indicativo de potencial inovador); e (iii) distribuição da amostra de modo que $80 \%$ das empresas da amostra sejam originárias dos estratos das potenciais inovadoras e $20 \%$ dos estratos sem indicação de potencial inovador.

Por fim, a seleção da amostra em cada estrato final foi feita de forma independente, com probabilidade de seleção proporcional ao número de pessoas ocupadas.

O tamanho da amostra da Pintec 2014 foi dimensionado pelo IBGE de forma a assegurar que o estimador do total de pessoal ocupado em cada estrato natural tivesse um coeficiente de variação de $12 \%$ e levando-se em consideração uma taxa de perda de $15 \%$, conforme a tabela 4.1 , a seguir.

Tabela 4.1 - Número de empresas selecionadas para a PINTEC, por estrato, segundo as atividades da indústria, do setor de eletricidade e gás e dos serviços selecionados: Brasil -2014

\begin{tabular}{lrrrr}
\hline & \multicolumn{4}{c}{ Empresas selecionadas } \\
\cline { 2 - 5 } $\begin{array}{l}\text { Atividades da indústria, do } \\
\text { setor de eletricidade e gás }\end{array}$ & & \multicolumn{3}{c}{ Estrato } \\
\cline { 2 - 5 } $\begin{array}{l}\text { e dos serviços } \\
\text { selecionado. }\end{array}$ & Total & Inovadoras & $\begin{array}{c}\text { Potencialmente } \\
\text { inovadoras }\end{array}$ & $\begin{array}{c}\text { Sem } \\
\text { indicação de } \\
\text { potencial } \\
\text { inovador }\end{array}$ \\
\hline Total & $\mathbf{1 7 . 1 7 1}$ & $\mathbf{5 . 7 8 6}$ & $\mathbf{7 . 6 6 2}$ & $\mathbf{3 . 7 2 3}$ \\
\hline Indústria & 14.387 & 4.439 & 6.932 & 3.016 \\
\hline Eletricidade e gás & 96 & 63 & 8 & 25 \\
\hline Serviços selecionados & 2.688 & 1.284 & 722 & 682 \\
\hline
\end{tabular}

Fonte: IBGE, Diretoria de Pesquisas, Coordenação de Indústria, Pesquisa de Inovação 2014.

\footnotetext{
${ }^{4}$ Diante da impossibilidade de uma operação de screening, são utilizadas informações oriundas de diversas fontes para gerar indicadores capazes de identificar este subconjunto (banco de dados de patentes e de contratos de transferência de tecnologia, relação de empresas que se beneficiaram de incentivos fiscais para P\&D, empresas inovadoras na Pintec, etc.).
} 


\subsection{2. \\ Construção da amostra estratificada do estudo}

Em consonância com a política de sigilo do IBGE, o pesquisador solicitou permissão para o uso dos microdados não desidentificados da Pintec 2014 submetendo um projeto de pesquisa direcionado para as questões de pesquisa da sua dissertação de mestrado. $\mathrm{O}$ foco da solicitação foram os microdados referentes a empresas da indústria de transformação que implementaram inovações e que estabeleceram relações de cooperação com outras organizações (tabela 4.2).

Tabela 4.2 - Empresas da indústria de transformação que implementaram inovações e com relações de cooperação com outras organizações: Brasil - 2014

\begin{tabular}{|c|c|c|c|}
\hline CNAE* & Setor da indústria de transformação & $\begin{array}{l}\text { Empresas que } \\
\text { implementaram inovações } \\
\text { e cooperaram com outras } \\
\text { organizações em projetos } \\
\text { de P\&D** }\end{array}$ & $\%$ \\
\hline Divisão & Total & 6.091 & 100 \\
\hline 10 & Fabricação de produtos alimentícios & 685 & 11,25 \\
\hline 11 & Fabricação de bebidas & 96 & 1,58 \\
\hline 12 & Fabricação de produtos de fumo & 6 & 0,10 \\
\hline 13 & Fabricação de produtos têxteis & 202 & 3,32 \\
\hline 14 & $\begin{array}{l}\text { Confecção de artigos do vestuário e } \\
\text { acessórios }\end{array}$ & 371 & 6,09 \\
\hline 15 & $\begin{array}{l}\text { Preparação de couros e fabricação de } \\
\text { artefatos de couro, artigos de viagem e } \\
\text { calçados }\end{array}$ & 273 & 4,48 \\
\hline 16 & Fabricação de produtos de madeira & 64 & 1,05 \\
\hline 17 & $\begin{array}{l}\text { Fabricação de celulose, papel e produtos e } \\
\text { papel }\end{array}$ & 59 & 0,97 \\
\hline 18 & Impressão e reprodução de gravações & 73 & 1,20 \\
\hline 19 & $\begin{array}{l}\text { Fabricação de coque, de produtos derivados } \\
\text { de petróleo e de biocombustíveis }\end{array}$ & 36 & 0,59 \\
\hline 20 & Fabricação de produtos químicos & 542 & 8,90 \\
\hline 21 & $\begin{array}{l}\text { Fabricação de produtos farmoquímicos e } \\
\text { farmacêuticos }\end{array}$ & 98 & 1,61 \\
\hline 22 & Fabricação de artigos de borracha e plástico & 350 & 5,75 \\
\hline 23 & $\begin{array}{l}\text { Fabricação de produtos de minerais não- } \\
\text { metálicos }\end{array}$ & 430 & 7,06 \\
\hline 24 & Metalurgia & 146 & 2,40 \\
\hline 25 & $\begin{array}{l}\text { Fabricação de produtos de metal, exceto } \\
\text { máquinas e equipamentos }\end{array}$ & 460 & 7,55 \\
\hline 26 & $\begin{array}{l}\text { Fabricação de equipamentos de informática, } \\
\text { produtos eletrônicos e ópticos }\end{array}$ & 317 & 5,20 \\
\hline 27 & $\begin{array}{l}\text { Fabricação de máquinas, aparelhos e } \\
\text { materiais elétricos }\end{array}$ & 267 & 4,38 \\
\hline 28 & Fabricação de máquinas e equipamentos & 439 & 7,21 \\
\hline 29 & $\begin{array}{l}\text { Fabricação de veículos automotores, } \\
\text { reboques e carrocerias }\end{array}$ & 247 & 4,06 \\
\hline 30 & $\begin{array}{l}\text { Fabricação de outros equipamentos de } \\
\text { transporte }\end{array}$ & 53 & 0,87 \\
\hline 31 & Fabricação de móveis & 418 & 6,86 \\
\hline 32 & Fabricação de produtos diversos & 245 & 4,02 \\
\hline 33 & $\begin{array}{l}\text { Manutenção, reparação e instalação de } \\
\text { máquinas e equipamentos }\end{array}$ & 214 & 3,51 \\
\hline
\end{tabular}

Notas: $\left({ }^{*}\right.$ ) Classificação Nacional de Atividades Econômicas - CNAE, versão 2.2 (IBGE, 2015).

$\left({ }^{* *}\right)$ Relações de cooperação com os seguintes parceiros: clientes ou consumidores; fornecedores; concorrentes; outra empresa do grupo; empresas de consultoria; universidades e institutos de pesquisa; centros de capacitação profissional; e instituições de testes, ensaios e certificações e assistência técnica.

Fonte: Elaboração própria a partir de dados da Pintec 2014 - tabela

1.1.17 (IBGE, 2016). 
Assim, elaborou-se o projeto conforme o modelo disponibilizado pelo IBGE e orientações para seu encaminhamento. Em novembro de 2018, o pesquisador submeteu o referido projeto ao Conselho de Sigilo da Pintec/IBGE, tendo sido aprovado meses depois após análise da relevância do projeto e da inexistência de ameaças ao sigilo dos dados das empresas.

$\mathrm{O}$ acesso aos microdados foi concedido a um Tecnologista em Informações Geográficas e Estatísticas do IBGE, designado como procurador do pesquisador neste projeto $^{5}$. O procurador compareceu à Sala de Sigilo nas dependências do IBGE no Rio de Janeiro no período determinado pelo Conselho, com o objetivo de assinar o termo de confidencialidade e alimentar os microdados no pacote estatístico SAS. Nesta fase, o pesquisador formulou em conjunto com a orientadora e o procurador do IBGE os modelos de regressão logística na linguagem SAS (código-fonte apresentado no apêndice 1) e interpretou os resultados das aplicações dos procedimentos de estimação de máxima verossimilhança e de seleção sequencial das variáveis explanatórias em cada um dos 60 modelos de regressão.

Com relação à construção da amostra, cabe ressaltar que 6.091 é o número estimado pelo IBGE do total de empresas da indústria de transformação, que implementaram inovações e com relações de cooperação com outras organizações em projetos de PD\&I. Para a amostra deste estudo empírico, considerou-se o número de empresas da indústria de transformação respondentes da Pintec, que implementaram inovações e com relações de cooperação com outras organizações em projetos de PD\&I no período 2012-2014. Assim, a amostra totalizou 1.520 empresas com informação sobre o conjunto das variáveis explanatórias do estudo empírico e que se apresentam nos modelos de regressão logística, como mostrado adiante.

Pela análise da tabela 4.2, foi possível constatar que não há concentração de um setor ou mais setores da indústria de transformação em relação aos demais. O setor de produtos alimentícios responde por $11,25 \%$ das empresas da indústria de transformação que implementaram inovações e cooperaram com outras

\footnotetext{
${ }^{5}$ José Eduardo de Oliveira Trindade, Tecnologista do IBGE e Mestre pelo Programa Pós-MQI da PUC-Rio.
} 
organizações, seguido dos setores químico (8,9\%); produtos de metal $(7,55 \%)$ e fabricação de máquinas e equipamentos $(7,21 \%)$.

Com o objetivo de investigar as contribuições de diferentes tipos de parceiros nos arranjos cooperativos para a apropriação de valor pelas inovações criadas, classificaram-se inicialmente as 1.520 empresas inovadoras com relações de cooperação com outras organizações no período 2012-2014, conforme a taxonomia de intensidade tecnológica concebida pela OCDE (2011) para os setores da indústria de transformação. A escala de intensidade tecnológica compreende quatro níveis: (i) alta; (ii) média/alta; (iii) média/baixa; e (iv) baixa.

Para posterior categorização das empresas de um determinado grupo de intensidade tecnológica (AT ou BT), calculou-se a força do regime no nível dos setores (CNAE 2.2, dois dígitos), pela média da ocorrência da utilização de um ou mais mecanismos de proteção intelectual pelas empresas de cada setor, conforme dados da tabelas 1.1.2 e 1.1.5 da Pintec 2008 (respostas binárias).

A tabela 4.3, a seguir, apresenta os resultados da classificação dos setores da indústria de transformação pela intensidade tecnológica e força do regime de apropriabilidade, tendo como base dos dados da Pintec 2008.

Como indicado nesta tabela, quando o valor médio do setor esteve acima do valor mediano de todos os setores de um determinado grupo (AT ou BT), ele foi classificado como tendo um regime de apropriabilidade forte; caso contrário, o setor foi classificado como tendo um regime de apropriabilidade fraco (Veugelers e Cassiman, 2005); Bönte e Keilbach, 2005; Lhuillery e Pfister, 2009; e Seo et al., 2017).

A amostra de 1.520 empresas foi estratificada segundo a intensidade tecnológica (OCDE, 2011) e a força do regime de apropriabilidade do setor no qual a empresa atua, formando-se quatro estratos, a saber: (i) agrupamento 'AT/FO - alta intensidade tecnológica/forte regime de apropriabilidade'; (ii) agrupamento 'AT/FR - alta intensidade tecnológica/ fraco regime de apropriabilidade'; (iii) agrupamento 'BT/FO - baixa intensidade tecnológica/regime forte de apropriabilidade'; e (iv) agrupamento 'BT/FR - baixa intensidade tecnológica/ fraco regime de apropriabilidade'. 
Tabela 4.3 - Classificação dos setores da indústria de transformação pela intensidade tecnológica e força do regime de apropriabilidade: Brasil - 2008

\begin{tabular}{|c|c|c|c|}
\hline $\begin{array}{l}\text { Intensidade } \\
\text { tecnológica } \\
\text { setorial }\end{array}$ & $\begin{array}{l}\text { Força do } \\
\text { regime de } \\
\text { apropriabilidade }\end{array}$ & Setor & $\begin{array}{l}\text { Cálculo da força } \\
\text { do regime de } \\
\text { apropriabilidade }\end{array}$ \\
\hline \multirow{8}{*}{$\begin{array}{l}\text { Alta } \\
\text { intensidade } \\
\text { tecnológica } \\
\text { (AT) }\end{array}$} & \multirow{4}{*}{ Forte $^{a}$} & Fabricação de produtos químicos & 0,942200 \\
\hline & & $\begin{array}{l}\text { Fabricação de produtos farmoquímicos e } \\
\text { farmacêuticos }\end{array}$ & 1,584127 \\
\hline & & $\begin{array}{l}\text { Fabricação de máquinas, aparelhos e } \\
\text { materiais elétricos }\end{array}$ & 0,994444 \\
\hline & & Fabricação de produtos diversos & 0,948969 \\
\hline & \multirow{4}{*}{ Fraco $^{a}$} & $\begin{array}{l}\text { Fabricação de equipamentos de } \\
\text { informática, produtos eletrônicos e óticos }\end{array}$ & 0,845224 \\
\hline & & Fabricação de máquinas e equipamentos & 0,720240 \\
\hline & & $\begin{array}{l}\text { Fabricação de veículos automotores } \\
\text { reboques e carrocerias }\end{array}$ & 0,673950 \\
\hline & & $\begin{array}{l}\text { Fabricação de outros equipamentos de } \\
\text { transporte exceto veículos automotores }\end{array}$ & 0,640884 \\
\hline \multirow{16}{*}{$\begin{array}{l}\text { Baixa } \\
\text { intensidade } \\
\text { tecnológica } \\
\text { (BT) }\end{array}$} & \multirow{8}{*}{ Forte $^{b}$} & Fabricação de bebidas & 1,652597 \\
\hline & & Fabricação de produtos de fumo & 1,062500 \\
\hline & & $\begin{array}{l}\text { Fabricação de celulose, papel e produtos } \\
\text { de papel }\end{array}$ & 0,600266 \\
\hline & & $\begin{array}{l}\text { Fabricação de coque, de produtos } \\
\text { derivados do petróleo e de } \\
\text { biocombustíveis }\end{array}$ & 0,709924 \\
\hline & & $\begin{array}{l}\text { Fabricação de artigos de borracha e } \\
\text { plástico }\end{array}$ & 0,726302 \\
\hline & & Metalurgia & 0,624811 \\
\hline & & $\begin{array}{l}\text { Fabricação de produtos de metal, exceto } \\
\text { máquinas e equipamentos }\end{array}$ & 0,461942 \\
\hline & & $\begin{array}{l}\text { Manutenção, reparação e instalação de } \\
\text { máquinas e equipamentos }\end{array}$ & 0,562500 \\
\hline & \multirow{8}{*}{ Fraco $^{b}$} & Fabricação de produtos alimentícios & 0,406111 \\
\hline & & Fabricação de produtos têxteis & 0,385771 \\
\hline & & $\begin{array}{l}\text { Confecção de artigos do vestuário e } \\
\text { acessórios }\end{array}$ & 0,214800 \\
\hline & & $\begin{array}{l}\text { Preparação de couros e fabricação de } \\
\text { artefatos de couro e artigos de viagem e } \\
\text { calçados }\end{array}$ & 0,379054 \\
\hline & & Fabricação de produtos de madeira & 0,211803 \\
\hline & & Fabricação de móveis & 0,285633 \\
\hline & & Impressão e reprodução de gravações & 0,284763 \\
\hline & & $\begin{array}{l}\text { Fabricação de produtos de minerais não } \\
\text { metálicos }\end{array}$ & 0,268645 \\
\hline
\end{tabular}

Notas: ${ }^{a}$ mediana $=0,893712 ;{ }^{\mathrm{b}}$ mediana $=0,434026$.

Fonte: Elaboração própria a patir de dados da Pintec 2008 - Tabelas 1.1.2 e 1.1.5 (IBGE, 2010).

Além da estratificação setorial, procedeu-se à estratificação por tamanho das empresas respondentes em cada agrupamento setorial, a saber: (i) micro e pequenas empresas; (ii) médias; e (iii) grandes (ver tabela 4.4). 
Tabela 4.4 - Caracterização da amostra e proporção entre observações e variáveis explanatórias do estudo empírico

\begin{tabular}{lllll}
\hline $\begin{array}{l}\text { Agrupamento } \\
\text { setorial }\end{array}$ & $\begin{array}{l}\text { Tamanho das } \\
\text { empresas }\end{array}$ & $\begin{array}{l}\text { Número de } \\
\text { observações }\end{array}$ & $\begin{array}{l}\text { Distribuição } \\
\text { percentual (\%) }\end{array}$ & $\begin{array}{l}\text { Proporção entre } \\
\text { observaçóes e variáveis } \\
\text { explanatórias }\end{array}$ \\
\hline \multirow{3}{*}{ AT/FO } & Micro e pequenas & 58 & 4 & 7 \\
\cline { 2 - 5 } & Médias & 135 & 9 & 17 \\
\cline { 2 - 5 } & Grandes & 113 & 7 & 14 \\
\hline \multirow{3}{*}{ AT/FR } & Micro e pequenas & 82 & 5 & 10 \\
\cline { 2 - 5 } & Médias & 165 & 11 & 21 \\
\cline { 2 - 5 } & Grandes & 101 & 7 & 13 \\
\hline \multirow{3}{*}{ BT/FO } & Micro e pequenas & 66 & 4 & 14 \\
\cline { 2 - 5 } & Médias & 109 & 7 & 20 \\
\cline { 2 - 5 } & Grandes & 83 & 5 & 24 \\
\hline \multirow{3}{*}{ BT/FR } & Micro e pequenas & 156 & 10 & \\
\cline { 2 - 5 } & Médias & 261 & 17 & 13 \\
\hline & Grandes & 191 & 100 & \\
\hline
\end{tabular}

Fonte: Elaboração própria.

O tamanho da amostra afeta a generalização dos resultados pela proporção entre observações e variáveis explanatórias, além de seu papel na determinação do poder estatístico do modelo. Uma regra geral observada é que a razão nunca deve ficar abaixo de 5 para 1, ou seja, cinco observações para cada variável explanatória na variável estatística. Apesar da proporção mínima ser de 5 para 1 , o nível desejado deve se situar entre 15 e 20 observações para cada variável explanatória (Hair et al., 2009). A tabela 4.4, a seguir, apresenta a proporção entre observações em cada agrupamento e variáveis explanatórias consideradas no presente estudo (para a relação de variáveis do estudo, ver subseção 4.3.3).

Como mostra a tabela 4.4, o nível desejado entre 15 e 20 observações por variável explanatória foi observado em cinco estratos. Em um segundo patamar, entre 14 e 10 observações, situam-se mais cinco estratos. Em apenas dois estratos - micro e pequenas empresas nos agrupamentos AT/FO - as proporções foram mais baixas, porém acima do nível mínimo de 5 observações.

\subsection{3.}

\section{Conteúdo da informação}

Com relação ao conteúdo da informação, procurou-se analisar se os microdados da Pintec 2014 correspondiam às informações requeridas e qual seria a forma mais adequada para a modelagem e análises pretendidas. Constatou-se que o conjunto de parceiros de arranjos cooperativos para inovação incluídos no 
modelo conceitual articulava-se com os microdados e alinhava-se aos resultados da revisão da literatura (capítulo 2).

Os microdados foram organizados de forma a testar as hipóteses apresentadas no quadro 4.1 e comprovar empiricamente o modelo conceitual da figura 4.1, em consonância com as seguintes categorias de variáveis:

- Cooperação interorganizacional: pretende-se analisar a influência dos diferentes parceiros sobre a apropriação de valor das inovações geradas em arranjos cooperativos. Na Pintec 2014, caracteriza-se a cooperação interorganizacional pela importância atribuída pelas empresas a cada tipo de parceiro em arranjos cooperativos para projetos de PD\&I, segundo uma escala de quatro níveis de importância: (i) alta; (ii) média; (iii) baixa; e (iv) não desenvolveu.

- Apropriação de valor das inovações geradas em arranjos cooperativos: associam-se a esta variável dependente os impactos decorrentes das inovações em cinco dimensões - impactos mercadológicos; na produção; ambientais; sociais; e regulatórios. Os impactos são expressos na Pintec 2014 pela importância atribuída pelas empresas aos impactos de umas dimensões citadas, segundo uma escala de quatro níveis de importância: (i) alta; (ii) média; (iii) baixa; e (iv) não desenvolveu.

Listam-se a seguir as oito variáveis explanatórias selecionadas para compor o modelo conceitual:

- Importância de clientes e consumidores como parceiros em arranjos cooperativos $\left(X_{\text {CLIE }}\right)$;

- Importância de fornecedores como parceiros em arranjos cooperativos $\left(X_{F O R N}\right)$;

- Importância de concorrentes como parceiros em arranjos cooperativos $\left(X_{C O N C}\right)$

- Importância de outra empresa do grupo como parceira em arranjos cooperativos $\left(X_{E M P R}\right)$;

- Importância de empresas de consultoria como parceiras em arranjos cooperativos $\left(X_{C O N S}\right)$;

- Importância de universidades ou institutos de pesquisa como parceiros em arranjos cooperativos $\left(X_{\text {ICTS }}\right)$;

- Importância de centros de capacitação profissional e assistência técnica como parceiros em arranjos cooperativos $\left(X_{C C A P}\right)$;

- Importância de instituições de ensaios e certificações como parceiras em arranjos cooperativos $\left(X_{C E R T}\right)$.

As variáveis de controle são:

- Tamanho das empresas da indústria de transformação, expresso pelas faixas de pessoal ocupado (VC1);

- Capacidade para inovar: empresas inovadoras de produto e/ou processo; 
ou com projetos incompletos ou abandonados (VC2);

- Capacidade para cooperar em projetos de PD\&I (VC3);

- Divisões da indústria de transformação, segundo CNAE a dois dígitos.

As variáveis do estudo empírico, seus códigos e escalas de medidas definidas na Pintec 2014 e os valores adotados neste estudo são apresentadas nos quadros 4.2 a 4.4 , a seguir.

Quadro 4.2 - Definição das variáveis dependentes do estudo, códigos, escalas de medidas e valores

\begin{tabular}{|c|c|c|c|c|}
\hline \multicolumn{2}{|c|}{ Categoria e denominação da variável } & \multirow{2}{*}{$\begin{array}{l}\text { Código } \\
Y_{M E R C}\end{array}$} & \multirow{2}{*}{$\begin{array}{l}\text { Escala de medida pela } \\
\text { Pintec } 2014 \\
\text { Categórica nominal } \\
1 \text { - Alta importância } \\
2 \text { - Média importância } \\
3 \text { - Baixa importância } \\
4 \text { - Não desenvolveu }\end{array}$} & \multirow{2}{*}{$\begin{array}{l}\text { Valores adotados no } \\
\text { estudo }\end{array}$} \\
\hline \multirow{5}{*}{ 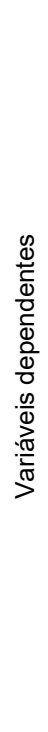 } & $\begin{array}{l}\text { Importância dos impactos das inovações } \\
\text { de produto e/ou processo, } \\
\text { implementadas, nestes casos referentes } \\
\text { a aspectos mercadológicos }\end{array}$ & & & \\
\hline & $\begin{array}{l}\text { Importância dos impactos das inovações } \\
\text { de produto e processo, implementadas, } \\
\text { nestes casos referentes a aspectos da } \\
\text { produção }\end{array}$ & $Y_{P R O D}$ & $\begin{array}{l}\text { Categórica nominal } \\
1 \text { - Alta importância } \\
2 \text { - Média importância } \\
3 \text { - Baixa importância } \\
4 \text { - Não desenvolveu }\end{array}$ & $\begin{array}{l}\text { Medida binária } \\
1 \text { - Se alta e média } \\
\text { importância } \\
0 \text { - Se baixa ou não } \\
\text { desenvolveu }\end{array}$ \\
\hline & $\begin{array}{l}\text { Importância dos impactos das inovações } \\
\text { de produto e processo, implementadas, } \\
\text { nestes casos referentes a aspectos } \\
\text { ambientais }\end{array}$ & $Y_{A M B I}$ & $\begin{array}{l}\text { Categórica nominal } \\
1 \text { - Alta importância } \\
2 \text { - Média importância } \\
3 \text { - Baixa importância } \\
4 \text { - Não desenvolveu }\end{array}$ & $\begin{array}{l}\text { Medida binária } \\
1 \text { - Se alta e média } \\
\text { importância } \\
0 \text { - Se baixa ou não } \\
\text { desenvolveu }\end{array}$ \\
\hline & $\begin{array}{l}\text { Importância dos impactos das inovações } \\
\text { de produto e processo implementadas. } \\
\text { Neste caso, referem-se a aspectos } \\
\text { sociais - saúde e segurança }\end{array}$ & $Y_{S O C I}$ & $\begin{array}{l}\text { Categórica nominal } \\
1 \text { - Alta importância } \\
2 \text { - Média importância } \\
3 \text { - Baixa importância } \\
4 \text { - Não desenvolveu }\end{array}$ & $\begin{array}{l}\text { Medida binária } \\
1 \text { - Se alta e média } \\
\text { importância } \\
0 \text { - Se baixa ou não } \\
\text { desenvolveu }\end{array}$ \\
\hline & $\begin{array}{l}\text { Importância dos impactos das inovações } \\
\text { implementadas, neste caso o } \\
\text { enquadramento em regulações e normas } \\
\text { padrão relativas ao mercado interno e } \\
\text { externo }\end{array}$ & $Y_{R E G U}$ & $\begin{array}{l}\text { Categórica nominal } \\
1 \text { - Alta importância } \\
2 \text { - Média importância } \\
3 \text { - Baixa importância } \\
4 \text { - Não desenvolveu }\end{array}$ & $\begin{array}{l}\text { Medida binária } \\
1 \text { - Se alta e média } \\
\text { importância; } 0 \text { - Se } \\
\text { baixa ou não } \\
\text { desenvolveu }\end{array}$ \\
\hline
\end{tabular}

Fonte: Elaboração própria.

Quadro 4.3 - Definição das variáveis de controle do estudo, códigos, escalas de medidas e valores

\begin{tabular}{|c|c|c|c|c|}
\hline \multicolumn{2}{|c|}{$\begin{array}{l}\text { Categoria e } \\
\text { denominação da variável }\end{array}$} & Código & Escala de medida pela Pintec 2014 & $\begin{array}{lll}\text { Valores adotados no } \\
\text { estudo }\end{array}$ \\
\hline \multirow{4}{*}{ 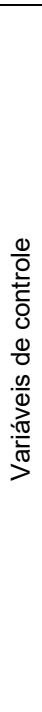 } & $\begin{array}{l}\text { Tamanho da empresa } \\
\text { da empresa - faixas } \\
\text { de pessoas ocupadas }\end{array}$ & $V C 1$ & $\begin{array}{l}\text { Categórica nominal (faixas) } \\
1 \text { - De } 10 \text { a } 29 \text { pessoas ocupadas } \\
2 \text { - De } 30 \text { a } 49 \text { pessoas ocupadas } \\
3 \text { - De } 50 \text { a } 99 \text { pessoas ocupadas } \\
4 \text { - De } 100 \text { a } 249 \text { pessoas ocupadas } \\
5 \text { - De } 250 \text { a } 499 \text { pessoas ocupadas } \\
6 \text { - Com } 500 \text { ou mais pessoas ocupadas }\end{array}$ & $\begin{array}{l}\text { Categórica nominal (faixas) } \\
1 \text { - micro e pequena [até } 99 \\
\text { pessoas ocupadas] } \\
2 \text { - média [100 a } 449] \\
3 \text { - grande [ } 500 \text { ou mais } \\
\text { pessoas] }\end{array}$ \\
\hline & $\begin{array}{l}\text { Capacidade para } \\
\text { inovar: empresas } \\
\text { inovadoras de } \\
\text { produto e/ou } \\
\text { processo; ou com } \\
\text { projetos incompletos } \\
\text { ou abandonados } \\
\end{array}$ & $V C 2$ & $\begin{array}{l}\text { Medida binária } \\
1 \text { - Se inovou (produto e/ou processo) ou } \\
\text { teve projetos incompletos ou } \\
\text { abandonados no período. } \\
0-\text { Se não inovou no período. }\end{array}$ & $\begin{array}{l}\text { Discreta binária } \\
1 \text { - Se inovou (produto e/ou } \\
\text { processo) ou teve projetos } \\
\text { incompletos ou } \\
\text { abandonados no período. } \\
0-\text { Se não inovou no } \\
\text { período. }\end{array}$ \\
\hline & $\begin{array}{l}\text { Envolvimento em } \\
\text { arranjos cooperativos } \\
\text { com outra(s) } \\
\text { organização(ões) com } \\
\text { vistas a desenvolver } \\
\text { atividades inovativas }\end{array}$ & $V C 3$ & $\begin{array}{l}\text { Medida binária } \\
1 \text { - A empresa esteve envolvida em } \\
\text { arranjos cooperativos para projetos de } \\
\text { PD\&I. } \\
0-\text { A empresa não esteve envolvida em } \\
\text { arranjos cooperativos para projetos de } \\
\text { PD\&I. }\end{array}$ & $\begin{array}{l}\text { Discreta binária } \\
1 \text { - Se cooperou em } \\
\text { projetos de PD\&l } \\
0 \text { - Se não cooperou em } \\
\text { projetos de PD\&I. }\end{array}$ \\
\hline & $\begin{array}{l}\text { Classificação setorial } \\
\text { (CNAE) da indústria } \\
\text { de transformação }\end{array}$ & $\begin{array}{l}\text { CNAE a } \\
\text { dois } \\
\text { dígitos }\end{array}$ & $\begin{array}{l}\text { Códigos CNAE da indústria de } \\
\text { transformação a dois dígitos. }\end{array}$ & $\begin{array}{l}\text { Códigos CNAE da indústria } \\
\text { de transformação a dois } \\
\text { dígitos. }\end{array}$ \\
\hline
\end{tabular}


Quadro 4.4 - Definição das variáveis explanatórias do estudo, códigos, escalas de medidas e valores

\begin{tabular}{|c|c|c|c|c|}
\hline \multicolumn{2}{|c|}{$\begin{array}{l}\text { Categoria e } \\
\text { denominação da variável }\end{array}$} & Código & $\begin{array}{l}\text { Escala de medida pela Pintec } \\
2014\end{array}$ & $\begin{array}{l}\text { Valores adotados no } \\
\text { estudo }\end{array}$ \\
\hline \multirow{5}{*}{ 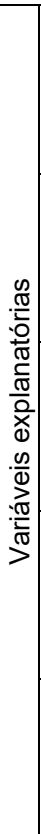 } & $\begin{array}{l}\text { Importância de } \\
\text { clientes e } \\
\text { consumidores como } \\
\text { parceiros }\end{array}$ & $X_{C L I E}$ & $\begin{array}{l}\text { Categórica nominal } \\
1 \text { - Alta importância } \\
2 \text { - Média importância } \\
3 \text { - Baixa importância } \\
4 \text { - Não desenvolveu }\end{array}$ & $\begin{array}{l}\text { Discreta binária } \\
1-\text { Se alta e média } \\
\text { importância } \\
0-\text { Se baixa ou não } \\
\text { desenvolveu }\end{array}$ \\
\hline & $\begin{array}{l}\text { Importância de } \\
\text { fornecedores como } \\
\text { parceiros }\end{array}$ & $X_{F O R N}$ & $\begin{array}{l}\text { Categórica nominal } \\
1 \text { - Alta importância } \\
2 \text { - Média importância } \\
3 \text { - Baixa importância } \\
4 \text { - Não desenvolveu }\end{array}$ & $\begin{array}{l}\text { Discreta binária } \\
1-\text { Se alta e média } \\
\text { importância } \\
0-\text { Se baixa ou não } \\
\text { desenvolveu }\end{array}$ \\
\hline & $\begin{array}{l}\text { Importância de } \\
\text { concorrentes como } \\
\text { parceiros }\end{array}$ & $X_{\text {CONC }}$ & $\begin{array}{l}\text { Categórica nominal } \\
1 \text { - Alta importância } \\
2 \text { - Média importância } \\
3 \text { - Baixa importância } \\
4 \text { - Não desenvolveu }\end{array}$ & $\begin{array}{l}\text { Discreta binária } \\
1-\text { Se alta e média } \\
\text { importância } \\
0-\text { Se baixa ou não } \\
\text { desenvolveu }\end{array}$ \\
\hline & $\begin{array}{l}\text { Importância de outra } \\
\text { empresa do grupo } \\
\text { como parceira }\end{array}$ & $X_{E M P R}$ & $\begin{array}{l}\text { Categórica nominal } \\
1 \text { - Alta importância } \\
2 \text { - Média importância } \\
3 \text { - Baixa importância } \\
4 \text { - Não desenvolveu }\end{array}$ & $\begin{array}{l}\text { Discreta binária } \\
1-\text { Se alta e média } \\
\text { importância } \\
0-\text { Se baixa ou não } \\
\text { desenvolveu }\end{array}$ \\
\hline & $\begin{array}{l}\text { Importância de } \\
\text { empresas de } \\
\text { consultoria como } \\
\text { parceiras }\end{array}$ & $X_{\text {CONS }}$ & $\begin{array}{l}\text { Categórica nominal } \\
1 \text { - Alta importância } \\
2 \text { - Média importância } \\
3 \text { - Baixa importância } \\
4 \text { - Não desenvolveu }\end{array}$ & $\begin{array}{l}\text { Discreta binária } \\
1-\text { Se alta e média } \\
\text { importância; } 0-\text { Se baixa ou } \\
\text { não desenvolveu }\end{array}$ \\
\hline \multirow{3}{*}{ 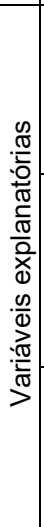 } & $\begin{array}{l}\text { Importância de } \\
\text { universidades ou } \\
\text { institutos de pesquisa } \\
\text { como parceiros }\end{array}$ & $X_{I C T S}$ & $\begin{array}{l}\text { Categórica nominal } \\
1 \text { - Alta importância } \\
2 \text { - Média importância } \\
3 \text { - Baixa importância } \\
4 \text { - Não desenvolveu }\end{array}$ & $\begin{array}{l}\text { Discreta binária } \\
1-\text { Se alta e média } \\
\text { importância } \\
0-\text { Se baixa ou não } \\
\text { desenvolveu }\end{array}$ \\
\hline & $\begin{array}{l}\text { Importância de } \\
\text { centros de } \\
\text { capacitação } \\
\text { profissional e } \\
\text { assistência técnica } \\
\text { como parceiros }\end{array}$ & $X_{C C A P}$ & $\begin{array}{l}\text { Categórica nominal } \\
1 \text { - Alta importância } \\
2 \text { - Média importância } \\
3 \text { - Baixa importância } \\
4 \text { - Não desenvolveu }\end{array}$ & $\begin{array}{l}\text { Discreta binária } \\
1-\text { Se alta e média } \\
\text { importância } \\
0-\text { Se baixa ou não } \\
\text { desenvolveu }\end{array}$ \\
\hline & $\begin{array}{l}\text { Importância de } \\
\text { instituições de ensaios } \\
\text { e certificações como } \\
\text { parceiras }\end{array}$ & $X_{C E R T}$ & $\begin{array}{l}\text { Categórica nominal } \\
1 \text { - Alta importância } \\
2 \text { - Média importância } \\
3 \text { - Baixa importância } \\
4 \text { - Não desenvolveu }\end{array}$ & $\begin{array}{l}\text { Discreta binária } \\
1-\text { Se alta e média } \\
\text { importância } \\
0-\text { Se baixa ou não } \\
\text { desenvolveu }\end{array}$ \\
\hline
\end{tabular}

Fonte: Elaboração própria.

\subsection{4.}

\section{Modelagem de dados e inferência estatística}

Uma vez estabelecidos os objetivos do estudo empírico e as hipóteses de pesquisa, definiram-se as variáveis dependentes, explanatórias e de controle. $\mathrm{Na}$ sequência, abordaram-se as questões da construção da amostra e avaliou-se o grau de atendimento das variáveis às suposições da regressão. Os próximos passos foram estimar os modelos de regressão e avaliar a qualidade de ajuste do modelo e a capacidade preditiva geral das variáveis explanatórias. Neste estágio, realizaram-se três tarefas básicas, como descrito em Hair et al. (2009):

- Seleção do método para especificar os modelos de regressão a serem estimados; 
- Estimação dos modelos de regressão, empregando-se um método de busca sequencial para seleção das variáveis explanatórias em cada modelo. Dentre os métodos de busca sequencial, escolheu-se a estimação Stepwise (Hair et al., 2009);

- Avaliação da qualidade de ajuste dos modelos propostos com emprego de testes estatísticos selecionados.

\subsubsection{1. \\ Seleção do método de regressão}

O método de regressão logística ${ }^{6}$ foi o método de escolha para investigar a influência de parceiros em arranjos cooperativos para projetos de $\mathrm{PD \&} \mathrm{I}^{7}$ sobre a apropriação de valor pelas inovações geradas por empresas brasileiras da indústria de transformação no período $2012-2014^{8}$, considerando-se fatores ambientais e características internas distintas. Para tal, as empresas foram classificadas em quatro grupos (AT/FO; AT/FR; BT/FO; e BT/FR) e em três faixas de pessoal ocupado (micro e pequenas; médias; e grandes empresas).

A análise comparativa dos estudos empíricos abordados no capítulo 2 (quadro 2.1) revelou que o método de regressão logística foi empregado na maioria dos trabalhos. Uma das principais razões pelas quais o modelo de regressão logística foi o mais utilizado deve-se à facilidade que proporciona na interpretação substantiva dos parâmetros do modelo, como se discute a seguir.

A escolha deste método para fins do presente estudo baseou-se nas seguintes razões: (i) não é necessário supor normalidade multivariada; (ii) é um método de análise multivariada muito adotado quando se pretende modelar relações entre variáveis categóricas dicotômicas; e (iii) a probabilidade de ocorrência de um evento pode ser estimada diretamente.

Pelas razões acima, considerou-se que o método de regressão logística seria o mais indicado para a investigação empírica que se pretende desenvolver. Isso posto, realizou-se a especificação formal do modelo de regressão logística, seguida da interpretação dos parâmetros do modelo e, posteriormente, a interpretação da qualidade de ajuste do modelo.

\footnotetext{
${ }^{6}$ Hair et al. (2009); Maddala (2003); Greene (2000); Hosmer e Lemeshow (2000); Kleinbaum e Klein (2010).

${ }^{7}$ Importância atribuída pelas empresas inovadoras aos diversos tipos de parceiros nos arranjos cooperativos no âmbito de seus projetos de inovação.

${ }^{8}$ Expressa pela importância atribuída pelas empresas inovadoras aos impactos de suas inovações (de processo e/ou produto).
} 
O método de regressão logit considera a componente sistemática:

$g\left(\mu_{i}\right)=\eta_{i}, i=1, \ldots, n$

Onde,

$\mu_{i}=E\left(y_{i}\right)$ e $g($. $)$ é uma função monótona e diferenciável, chamada função de ligação.

A função logit é expressa por meio da função de ligação abaixo:

Logit $-\eta=\log \left(\frac{\mu}{1-\mu}\right)$

Na sequência, foram elaborados os modelos de regressão logística teóricos, expressos pelas equações 3 a 7, que se referem aos impactos classificados em cinco dimensões: (i) mercadológicos; (ii) na produção; (iii) ambientais; (iv) sociais; e (v) regulatórios.

$$
\begin{gathered}
Y_{M E R C}=\beta_{0}+\beta_{1 m} X_{C L I E ; m}+\beta_{2 n} X_{F O R N ; n}+\beta_{3 o} X_{C O N C ; o}+\beta_{4 p} X_{E M P R ; p}+ \\
\beta_{5 q} X_{C O N S ; q}+\beta_{6 r} X_{I C T S ; r}+\beta_{7 s} X_{C C A P ; s}+\beta_{8 t} X_{C E R T ; t}+\varepsilon
\end{gathered}
$$

$$
\begin{aligned}
Y_{P R O D}= & \beta_{0}+\beta_{1 m} X_{C L I E ; m}+\beta_{2 n} X_{F O R N ; n}+\beta_{3 o} X_{C O N C ; o}+\beta_{4 p} X_{E M P R ; p}+ \\
& \beta_{5 q} X_{C O N S ; q}+\beta_{6 r} X_{I C T S ; r}+\beta_{7 s} X_{C C A P ; s}+\beta_{8 t} X_{C E R T ; t}+
\end{aligned}
$$

$\varepsilon$

$$
\begin{gathered}
Y_{A M B I}=\beta_{0}+\beta_{1 m} X_{C L I E ; m}+\beta_{2 n} X_{F O R N ; n}+\beta_{3 o} X_{C O N C ; o}+\beta_{4 p} X_{E M P R ; p}+ \\
\beta_{5 q} X_{C O N S ; q}+\beta_{6 r} X_{I C T S ; r}+\beta_{7 s} X_{C C A P ; S}+\beta_{8 t} X_{C E R T ; t}+\varepsilon \\
Y_{S O C I}=\beta_{0}+\beta_{1 m} X_{C L I E ; m}+\beta_{2 n} X_{F O R N ; n}+\beta_{3 o} X_{C O N C ; o}+\beta_{4 p} X_{E M P R ; p}+ \\
\beta_{5 q} X_{C O N S ; q}+\beta_{6 r} X_{I C T S ; r}+\beta_{7 s} X_{C C A P ; s}+\beta_{8 t} X_{C E R T ; t}+\varepsilon \\
Y_{R E G U}=\beta_{0}+\beta_{1 m} X_{C L I E ; m}+\beta_{2 n} X_{F O R N ; n}+\beta_{3 o} X_{C O N C ; o}+\beta_{4 p} X_{E M P R ; p}+ \\
\beta_{5 q} X_{C O N S ; q}+\beta_{6 r} X_{I C T S ; r}+\beta_{7 s} X_{C C A P ; S}+\beta_{8 t} X_{C E R T ; t}+\varepsilon
\end{gathered}
$$

Onde:

$X_{C L I E}$ - Variável explanatória referente a "Clientes e consumidores como parceiros em arranjos cooperativos para projetos de PD\&I"; $m=1$.

$X_{F O R N}$ - Variável explanatória referente a "Fornecedores como parceiros em arranjos cooperativos para projetos de PD\&I"; $\mathrm{n}=1$.

$X_{C O N C}$ - Variável explanatória e referente a "Concorrentes como parceiros em arranjos cooperativos para projetos de PD\&I"; $o=1$. 
$X_{E M P R}$ - Variável explanatória referente a "Outra empresa do grupo como parceira em arranjos cooperativos para projetos de PD\&I"; $p=1$.

$X_{\text {CONS }}$ - Variável explanatória referente a "Empresas de consultoria como parceiras em arranjos cooperativos para projetos de PD\&I"; q = 1 .

$X_{\text {ICTS }}$ - Variável explanatória referente a "Universidades ou institutos de pesquisa como parceiros em arranjos cooperativos para projetos de PD\&I"; $r=1$.

$X_{C C A P}$ - Variável explanatória referente a "Centros de capacitação profissional e assistência técnica como parceiros em arranjos cooperativos para projetos de PD\&I"; $\mathrm{s}=1$.

$X_{C E R T}$ - Variável explanatória referente a "Instituições de ensaios e certificações como parceiras em arranjos cooperativos para projetos de PD\&I"; $t$ $=1$.

$\beta$ - Parâmetros do modelo.

$\varepsilon-$ Erro.

No total, foram gerados 60 modelos (um por estrato da amostra), que permitiram evidenciar a influência dos diversos parceiros em arranjos cooperativos para projetos de PD\&I sobre a apropriação de valor das inovações geradas pelas empresas da indústria de transformação no Brasil. Assim, analisando-se cada modelo foi possível correlacionar os impactos das inovações geradas em arranjos cooperativos ${ }^{9}$ aos principais parceiros para projetos de PD\&I de empresas de quatro agrupamentos setoriais distintos da indústria de transformação brasileira (AT/FO; AT/FR; BT/FO; e BT/FR).

\subsubsection{2.}

\section{Estimação dos modelos de regressão}

Para estimar as equações de regressão (3) a (7) de cada um dos 60 modelos, empregou-se um método de busca sequencial, considerando-se o conjunto de variáveis definidas anteriormente. Dentre os métodos de busca sequencial, escolheu-se o procedimento Stepwise, segundo o qual é possível acrescentar ou eliminar variáveis dos modelos até que alguma medida geral de critérios seja alcançada.

A estimação Stepwise é considerada a abordagem sequencial mais comum para a seleção de variáveis a serem incluídas em modelos de regressão,

\footnotetext{
9 Impactos mercadológicos; impactos na produção; impactos ambientais; impactos sociais; e impactos regulatórios.
} 
começando-se pela seleção do melhor preditor da variável dependente. Ela permite examinar a contribuição de cada variável explanatória para os modelos de regressão. Variáveis explanatórias adicionais são selecionadas em termos da capacidade explicativa incremental que podem acrescentar ao modelo de regressão. As variáveis explanatórias são acrescentadas ao modelo final desde que seus coeficientes de correlação parcial sejam estatisticamente significantes. Algumas variáveis explanatórias poderão cair para um nível não significante, quando uma ou outra variável explanatória for acrescentada ao modelo.

A estimação Stepwise compreende cinco passos, como descrito por Hair et al., 2009, p. 179):

- Selecionar a variável explanatória que é mais fortemente correlacionada com a variável dependente. A equação neste passo é: $Y=\beta_{0}+\beta_{1} X_{1}$

- Examinar os coeficientes de correlação parcial para encontrar uma variável explanatória adicional, que explique a maior parte estatisticamente significante da variância não explicada (erro) remanescente da primeira equação de regressão;

- Recalcular a equação de regressão usando as duas variáveis explanatórias e examinar o valor parcial $\mathrm{F}$ para a variável original no modelo para ver se esta ainda faz uma contribuição significante, dada a presença da nova variável independente. Se não for o caso, eliminar a variável. Se a variável original ainda der uma contribuição significante, a equação será $Y=\beta_{0}+\beta_{1} X_{1}+\beta_{2} X_{2}$

- Continuar este procedimento, examinando todas as variáveis explanatórias não-presentes no modelo para determinar se alguma faria uma adição estatisticamente significante para a equação corrente. Em caso positivo, ela deveria ser incluída em uma equação revisada; e

- Continuar adicionando variáveis explanatórias até que nenhuma das variáveis candidatas remanescentes para inclusão possa contribuir em melhora estatisticamente significante na precisão preditiva. Isso ocorre quando todos os coeficientes de regressão parcial remanescentes forem não-significantes.

Neste estudo, utilizou-se a funcionalidade Stepwise Selection (STEPWISE) do pacote estatístico SAS para os 60 modelos de regressão focalizados neste estudo empírico. A título de exemplo, tomou-se o caso concreto do modelo $Y_{A M B I}$ gerado a partir dos dados das empresas de médio porte do agrupamento setorial BT/FO (extrato BT/FO - Médias empresas'). 
Partiu-se do modelo de regressão nulo, ou seja, somente com o intercepto sem a inclusão de nenhuma variável explanatória, chegando-se aos resultados mostrados nas tabelas 4.5 e 4.6 , a seguir.

Tabela 4.5 - Resultados do modelo nulo $Y_{A M B I}$ referente ao estrato 'BT/FO - Médias empresas': passo 0 da estimação Stepwise no caso concreto

\begin{tabular}{lllll}
\hline Parâmetro & $\begin{array}{l}\text { Coeficiente } \\
\text { estimado }(\beta)\end{array}$ & $\begin{array}{l}\text { Erro padrão } \\
(\varepsilon)\end{array}$ & $\begin{array}{l}\text { Wald } \\
\text { Qui quadrado }\end{array}$ & $\begin{array}{l}\text { Significância } \\
\left(\operatorname{Pr}>\mathrm{X}^{2}\right)\end{array}$ \\
\hline Intercepto & 10,622 & 0,2192 & 234,782 & $<0,0001$ \\
\hline $\begin{array}{l}\text { Qualidade de ajuste } \\
\text { do modelo }\end{array}$ & & & Qui quadrado & $\begin{array}{l}\text { Significância } \\
\left(\operatorname{Pr}>\mathrm{X}^{2}\right)\end{array}$ \\
\hline $\begin{array}{l}\text { Razão de } \\
\text { verossimilhança }\end{array}$ & & 45,174 & 0,0336 \\
\hline $\begin{array}{l}\text { Log-verossimilhança } \\
\text { (modelo nulo) }\end{array}$ & 124,210 & & \\
\hline Número de casos & 109 & & & \\
\hline
\end{tabular}

Fonte: Elaboração própria.

Ainda neste passo 0 , analisou-se a significância de todas as variáveis explanatórias elegíveis para entrada no modelo em questão (tabela 4.6).

Tabela 4.6 - Significância das variáveis explanatórias para entrada no modelo $Y_{A M B I}$ referente ao estrato 'BT/FO - Médias empresas': análise no caso concreto

\begin{tabular}{lll}
\hline Variável explanatória & Estatística de score & Significância \\
\hline$X_{C L I E}$ & 0,1582 & 0,6908 \\
\hline$X_{F O R N}$ & 0,5816 & 0,4457 \\
\hline$X_{C O N C}$ & 0,4734 & 0,4914 \\
\hline$X_{E M P R}$ & 46,434 & 0,0312 \\
\hline$X_{C O N S}$ & 0,0256 & 0,8729 \\
\hline$X_{I C T S}$ & 0,0401 \\
\hline$X_{C C A P}$ & 42,130 & 0,1290 \\
\hline$X_{C E R T}$ & 23,048 & 0,6661 \\
\hline
\end{tabular}

Fonte: Elaboração própria.

No passo 1 da estimação Stepwise, selecionou-se a mais elevada correlação bivariada e construiu-se a seguinte equação de regressão usando apenas essa variável explanatória $\left(X_{E M P R}\right)$, a saber: $Y_{A M B I}=\beta_{0}+\beta_{1} X_{E M P R}$. Com $X_{E M P R}$ na equação de regressão, os resultados do passo 1 podem ser vistos na tabela 4.7, a seguir.

Tabela 4.7 - Resultados da entrada de $X_{E M P R}$ no modelo $Y_{A M B I}$ referente ao estrato BT/FO - Médias empresas: passo 1 da estimação Stepwise: análise no caso concreto

\begin{tabular}{|c|c|c|c|c|}
\hline Parâmetro & $\begin{array}{l}\text { Coeficiente } \\
\text { estimado }(\beta)\end{array}$ & $\begin{array}{l}\text { Erro } \\
\text { padrão }(\varepsilon)\end{array}$ & $\begin{array}{l}\text { Wald } \\
\text { Qui quadrado }\end{array}$ & $\begin{array}{l}\text { Significância } \\
\left(\mathrm{Pr}>\mathrm{X}^{2}\right)\end{array}$ \\
\hline Intercepto & 0,0849 & 0,4926 & 0,0297 & 0,8631 \\
\hline \multicolumn{5}{|l|}{ Variável explanatória } \\
\hline$X_{E M P R}$ & 0,3464 & 0,1635 & 44,913 & 0,0341 \\
\hline $\begin{array}{l}\text { Qualidade de ajuste do } \\
\text { modelo }\end{array}$ & & & Qui quadrado & $\begin{array}{l}\text { Significância } \\
\left(\mathrm{Pr}>\mathrm{X}^{2}\right)\end{array}$ \\
\hline $\begin{array}{l}\text { Capacidade preditiva } \\
\text { (Índice c) }\end{array}$ & 0,621 & & & \\
\hline Razão de verossimilhança & 91,781 & & 91,781 & 0,0102 \\
\hline $\begin{array}{l}\text { Log-verossimilhança } \\
\text { (modelo nulo) }\end{array}$ & 124,210 & & & \\
\hline $\begin{array}{l}\text { Log-verossimilhança } \\
\text { (modelo estimado) }\end{array}$ & 119,692 & & & \\
\hline Número de casos & 109 & & & \\
\hline
\end{tabular}


Com relação aos resultados do passo 2 apresentados na tabela 4.7, observase que uma porção significativa da variância na variável dependente $Y_{A M B I}$ pode ser explicada por $X_{E M P R}$. No entanto, o procedimento Stepwise indicou também que se uma segunda variável fosse adicionada ao maior coeficiente de correlação parcial com a variável dependente a um nível de significância 0,05 , a capacidade preditiva do modelo de regressão geral poderia ter um aumento significativo. Neste passo 1, o valor de log-verossimilhança reduziu de 124,210 no modelo nulo para 119,692 .

Na sequência, repete-se o procedimento, analisando-se a significância das variáveis explanatórias restantes (tabela 4.8).

Tabela 4.8 - Significância das variáveis explanatórias após entrada de $X_{E M P R}$ no modelo $Y_{A M B I}$ referente ao estrato 'BT/FO - Médias empresas': análise no caso concreto

\begin{tabular}{lll}
\hline Variável explanatória & Estatística de score & Significância \\
\hline$X_{\text {CLIE }}$ & 0,0241 & 0,8765 \\
\hline$X_{F O R N}$ & 0,1615 & 0,6878 \\
\hline$X_{\text {CONC }}$ & 10,936 & 0,2957 \\
\hline$X_{\text {CONS }}$ & 0,0168 & 0,8970 \\
\hline$X_{I C T S}$ & 49,058 & 0,0268 \\
\hline$X_{C C A P}$ & 22,186 & 0,1364 \\
\hline$X_{C E R T}$ & 0,3173 & 0,5732
\end{tabular}

Fonte: Elaboração própria.

Da tabela 4.8 selecionou-se a correlação bivariada mais elevada $\left(X_{\text {ICTS }}\right)$. A nova equação de regressão foi a seguinte: $Y_{A M B I}=\beta_{0}+\beta_{1} X_{E M P R}+\beta_{2} X_{I C T S}$.

Na tabela 4.9, a seguir, mostram-se os resultados da entrada desta segunda variável explanatória no modelo de regressão em questão.

Tabela 4.9 - Resultados da entrada de $X_{I C T S}$ no modelo $Y_{A M B I}$ referente ao estrato 'BT/FO - Médias empresas': passo 2 da estimação Stepwise no caso concreto

\begin{tabular}{lllll}
\hline Parâmetro & $\begin{array}{l}\text { Coeficiente } \\
\text { estimado }(\beta)\end{array}$ & $\begin{array}{l}\text { Erro } \\
\text { padrão }(\varepsilon)\end{array}$ & $\begin{array}{l}\text { Wald } \\
\text { Qui quadrado }\end{array}$ & $\begin{array}{l}\text { Significância } \\
\left(P_{>}>\mathrm{X}^{2}\right)\end{array}$ \\
\hline Intercepto & 13,030 & 0,8263 & 24,868 & 0,1148 \\
\hline Variável explanatória & & & & \\
\hline$X_{E M P R}$ & 0,3826 & 0,1695 & 50,914 & 0,0240 \\
\hline$X_{I C T S}$ & 0,4108 & 0,1902 & 46,642 & 0,0308 \\
\hline $\begin{array}{l}\text { Qualidade de ajuste do } \\
\text { modelo }\end{array}$ & & Qui quadrado & $\begin{array}{l}\text { Significância } \\
(\text { Pr>X })\end{array}$ \\
\hline $\begin{array}{l}\text { Capacidade preditiva } \\
\text { (Índice c) }\end{array}$ & 0,708 & & \\
\hline Razão de verossimilhança & & & \\
\hline $\begin{array}{l}\text { Log-verossimilhança } \\
\text { (modelo nulo) }\end{array}$ & 124,210 & 91,781 & \\
\hline $\begin{array}{l}\text { Log-verossimilhança } \\
\text { (modelo estimado) }\end{array}$ & 115,032 & & \\
\hline Número de casos & 109 & & \\
\hline
\end{tabular}


Novamente, observa-se que uma porção significativa da variância na variável dependente $Y_{A M B}$ pode ser explicada pelas variáveis $X_{E M P R}$ e $X_{I C T S}$, mas o procedimento Stepwise apontou que se uma terceira variável for adicionada ao maior coeficiente de correlação parcial com a variável dependente ao nível de significância 0,5 , o poder preditivo do modelo de regressão geral pode ter um aumento até maior que no passo anterior. Neste passo 2, o valor de logverossimilhança reduziu de 124,210 no modelo nulo para 115,032.

Assim, repete-se o procedimento, analisando-se a significância das variáveis explanatórias restantes (tabela 4.10).

Tabela 4.10 - Significância das variáveis explanatórias após entrada de $X_{E M P R}$ e $X_{I C T S}$ no modelo $Y_{A M B I}$ referente ao estrato 'BT/FO - Médias empresas': análise no caso concreto

\begin{tabular}{lll}
\hline Variável explanatória & Estatística de score & Significância \\
\hline$X_{C L I E}$ & 0,2800 & 0,5967 \\
\hline$X_{F O R N}$ & 0,6825 & 0,4087 \\
\hline$X_{C O N C}$ & 32,285 & 0,0724 \\
\hline$X_{C O N S}$ & 0,3667 & 0,5448 \\
\hline$X_{C C A P}$ & 0,0151 & 0,9021 \\
\hline$X_{C E R T}$ & 40,805 & 0,0434 \\
\hline
\end{tabular}

Fonte: Elaboração própria.

No passo 3 da estimação Stepwise, selecionou-se da tabela 4.10 a correlação bivariada mais elevada $\left(X_{C E R T}\right)$. A nova equação de regressão foi a seguinte: $Y_{A M B I}$ $=\beta_{0}+\beta_{1} X_{E M P R}+\beta_{2} X_{I C T S}+\beta_{3} X_{C E R T}$.

$\mathrm{Na}$ tabela 4.11, apresentam-se os resultados da entrada desta terceira variável explanatória no modelo de regressão em questão.

Tabela 4.11 - Resultados da entrada de $X_{C E R T}$ no modelo $Y_{A M B I}$ referente ao estrato 'BT/FO - Médias empresas': passo 3 da estimação Stepwise no caso concreto

\begin{tabular}{|c|c|c|c|c|}
\hline Parâmetro & $\begin{array}{l}\text { Coeficiente } \\
\text { estimado }(\beta)\end{array}$ & $\begin{array}{l}\text { Erro } \\
\text { padrão }(\varepsilon)\end{array}$ & $\begin{array}{l}\text { Wald } \\
\text { Qui quadrado }\end{array}$ & $\begin{array}{l}\text { Significância } \\
\left(\operatorname{Pr}>X^{2}\right)\end{array}$ \\
\hline Intercepto & 10,787 & 0,8424 & 16,398 & 0,2004 \\
\hline \multicolumn{5}{|l|}{ Variável explanatória } \\
\hline$X_{E M P R}$ & 0,4342 & 0,1753 & 61,340 & 0,0133 \\
\hline$X_{I C T S}$ & 0,7102 & 0,2567 & 76,534 & 0,0057 \\
\hline$X_{C E R T}$ & 0,4815 & 0,2455 & 38,453 & 0,0499 \\
\hline $\begin{array}{l}\text { Qualidade de ajuste do } \\
\text { modelo }\end{array}$ & & & Qui quadrado & $\begin{array}{l}\text { Significância } \\
\left(\operatorname{Pr}>X^{2}\right)\end{array}$ \\
\hline $\begin{array}{l}\text { Capacidade preditiva } \\
\text { (Índice c) }\end{array}$ & 0,708 & & & \\
\hline Razão de verossimilhança & & & 135,427 & 0,0036 \\
\hline $\begin{array}{l}\text { Log-verossimilhança } \\
\text { (modelo nulo) }\end{array}$ & 124,210 & & & \\
\hline $\begin{array}{l}\text { Log-verossimilhança } \\
\text { (modelo estimado) }\end{array}$ & 110,667 & & & \\
\hline $\begin{array}{l}\text { Teste de Hosmer- } \\
\text { Lemeshow }\end{array}$ & & & 59,688 & 0,5434 \\
\hline Número de casos & 109 & & & \\
\hline
\end{tabular}


Em seguida, analisou-se a significância das variáveis explanatórias restantes para entrada (ou não) de variáveis no modelo em questão (tabela 4.12).

Tabela 4.12 - Significância das variáveis explanatórias após entrada de $X_{E M P R}, X_{I C T S} \mathrm{e}$ $X_{C E R T}$ no modelo $Y_{A M B I}$ referente ao estrato 'BT/FO - Médias empresas': análise no caso concreto

\begin{tabular}{lll}
\hline Variável explanatória & Estatística de score & Significância \\
\hline$X_{C L I E}$ & 0,1585 & 0,6905 \\
\hline$X_{F O R N}$ & 0,2238 & 0,6361 \\
\hline$X_{C O N C}$ & 23,360 & 0,1264 \\
\hline$X_{C O N S}$ & 0,0345 & 0,8526 \\
\hline$X_{C C A P}$ & 0,2763 & 0,5991 \\
\hline
\end{tabular}

Fonte: Elaboração própria.

Ao se observar os resultados da tabela 4.12, constatou-se que nenhuma das variáveis candidatas remanescentes para inclusão no modelo atendia ao nível de significância de 5\%, indicando que nenhum efeito adicional seria adicionado ao modelo em relação à melhoria da capacidade preditiva do modelo.

Uma questão crítica a ser considerada no procedimento Stepwise é a seleção das variáveis ocorre uma de cada vez. Supondo que as variáveis explanatórias $X_{C O N C}$ e $X_{C C A P}$ explicassem juntas uma parte significante da variância (cada uma, dada a presença da outra), mas nenhuma fosse significante quando considerada individualmente. Nessa situação, nenhuma delas deveria ser considerada para o modelo final.

De fato, para a efetiva interpretação da variável estatística de regressão, deve-se analisar a correlação entre as variáveis explanatórias, sendo que este é um problema dos dados e não do modelo em si (Hair et al., 2009). A maneira mais simples sugerida por esses autores para identificar a colinearidade é um exame da matriz de correlação para as variáveis explanatórias. A presença de elevadas correlações (em geral, 0,90 ou até superiores) é a primeira indicação de colinearidade substancial.

Para avaliar a multicolinearidade em regressão, emprega-se a medida direta de multicolinearidade, que é a tolerância. Define-se esta medida como a quantia de variabilidade da variável explanatória selecionada não explicada pelas outras variáveis explanatórias. A tolerância pode ser definida em dois passos: (i) 
considerar cada variável explanatória, uma por vez, e calcular $\mathrm{R}^{2}{ }^{10}$. Assim, a variável explanatória selecionada é transformada em uma variável dependente prevista pelas demais; e (ii) calcular a tolerância como $1-\mathrm{R}^{2}$. A título de exemplo, se as outras variáveis explanatórias explicam $25 \%$ da variável selecionada $\mathrm{X}_{1}\left(\mathrm{R}^{2}\right.$ $=0,25)$, então o valor de tolerância de $X_{1}$ é $0,75(1-0,25=0,75)$. Quando o valor de tolerância é alto significa um pequeno grau de multicolinearidade.

No entanto, como não existe nos modelos logit uma estatística semelhante ao $\mathrm{R}^{2}$ da análise de regressão (que possa ser interpretado como a proporção da variância da variável dependente que é “explicada" pelas variáveis explanatórias), algumas medidas de pseudo- $\mathrm{R}^{2}$ têm sido sugeridas (Aldrich e Nelson, 1984). Na modelagem em foco, não foi possível dispor dos microdados da Pintec 2014, após a segunda solicitação dos dados, ocasião em que se identificou a necessidade de se analisar a ocorrência de multicolinearidade. No entanto, pelas características das variáveis explanatórias, espera-se que a multicolineraridade seja muita baixa ou inexistente.

A estimação sequencial Stepwise descrita neste item para o modelo $Y_{A M B}$ (referente ao estrato da amostra "BT/FO - médias empresas") foi realizada para todos os 60 modelos de regressão estimados que integram este estudo empírico. Com as variáveis explanatórias selecionadas em cada um dos modelos e os coeficientes de regressão estimados, procedeu-se à avaliação da qualidade de ajuste dos modelos de estimação, como descrito no item seguinte.

\subsubsection{3.}

\section{Avaliação da qualidade de ajuste dos modelos de estimação}

Para a avaliação da qualidade de ajuste global dos modelos estimados, dispõe-se de várias medidas e testes estatísticos. Iniciando-se pela avaliação da capacidade preditiva do modelo estimado, esse autor descreve algumas medidas não paramétricas, como o Índice c; Índice D de Sommer; Índice Gama de Goodman-Kruskal; e Índice Tau-a de Kendall. Segundo ele, quanto maior o valor de cada um desses índices, melhor a capacidade do modelo de prever as probabilidades da variável dependente (Pino, 2007).

\footnotetext{
${ }^{10} \mathrm{~A}$ quantia da variável em questão que é explicada por todas as demais variáveis explanatórias no modelo de regressão.
} 
Neste estudo empírico, será adotado o Índice c para medir a capacidade preditiva dos 60 modelos estimados, que é definido como a relação entre os pares concordantes mais metade dos pares empatados e o total de pares com respostas diferentes (Pino, 2007).

A segunda medida é um teste de ajustamento, análogo ao teste $\mathrm{F}$ usado em análise de regressão, para testar a hipótese conjunta de que todos os coeficientes, exceto o intercepto, sejam nulos, baseando-se no princípio da razão de verossimilhança. A hipótese $\mathrm{H} 0: \beta=0$ pode ser testada pelo teste da razão de verossimilhança, resultando em um valor de qui-quadrado (quanto maior, melhor o ajustamento do modelo).

A terceira é a estatística da log-verossimilhança que avalia a significância global do modelo relativamente ao modelo nulo. A regressão logística mede o ajuste da estimação do modelo com o valor -2 vezes o logaritmo do valor da verossimilhança, também chamado de $-2 \operatorname{LogL}$. O valor mínimo para $-2 \operatorname{LogL}$ é 0 , correspondente a um ajuste perfeito (verossimilhança $=1$, então $-2 \log L=0$ ). Desse modo, melhor será o ajuste do modelo, quanto menor o valor -2LogL.

Esse valor pode ser usado para comparar equações de regressão quanto à diferença em ajuste preditivo de uma equação para outra, com testes estatísticos para significância dessas diferenças (Hair et al., 2009). O método básico consiste dos seguintes passos: (i) estimar um modelo nulo, que poderá atuar como uma referência em relação à qual qualquer modelo contendo variáveis explanatórias pode ser comparado; (ii) estimar o modelo proposto, com as variáveis explanatórias a serem incluídas no modelo de regressão logística. O ajuste deverá melhorar em relação ao modelo nulo, resultando em um valor de -2LogL menor; e (iii) avaliar a significância estatística do valor de -2LogL entre os dois modelos (nulo versus proposto).

Neste estudo, decidiu-se pelo emprego dos seguintes testes estatísticos, além dos já citados: (i) teste estatístico de Wald; e (iii) teste de Hosmer-Lemeshow.

Em regressão logística, usa-se o teste estatístico de Wald para verificar a significância estatística para cada coeficiente de regressão estimado, com o objetivo de se testar as hipóteses formuladas, como se faz em regressão múltipla (Hair et al., 2009). 
Com base no teste estatístico de Wald, podem ser verificadas duas situações (Silva, 2003):

- Para um nível de significância de 5\%, o coeficiente estimado não é estatisticamente significativo, o que leva a não rejeição da hipótese nula, sob a qual não existe relação entre duas variáveis. Perante esta situação, verifica-se se a exclusão dessa variável explanatória do modelo altera ou não a significância das outras variáveis explanatórias. Verifica-se ainda se existem mudanças na qualidade de ajuste global do modelo;

- Para um nível de significância de 5\%, o coeficiente estimado é estatisticamente significativo, pelo que se rejeita a hipótese nula de que não existe relação entre duas variáveis. Desse modo, conclui-se que existe uma relação entre essas variáveis, sendo necessário verificar se a relação estabelecida mantém o mesmo sentido ou, pelo contrário, se o sentido é simétrico àquele considerado na formulação da hipótese. A relação entre duas variáveis mantém o mesmo sentido, quando o sinal do coeficiente estimado corresponde ao sinal esperado para esse mesmo coeficiente. Caso contrário, o sentido da relação será invertido se o sinal do coeficiente se altera relativamente ao esperado.

Outro teste estatístico empregado foi o teste de Hosmer-Lemeshow. Esses autores desenvolveram um teste de classificação, no qual os casos são primeiramente divididos em aproximadamente 10 classes iguais, podendo variar esse número de classes. Em seguida, comparam-se os números de eventos reais e previstos em cada classe com a estatística qui-quadrado. Conforme Hair et al. (2009) e Hosmer e Lemeshow (2000, p. 36-40), esse teste fornece uma medida ampla de precisão preditiva que é baseada na real previsão da variável dependente e não no valor da razão de verossimilhança, mas também trabalha com distribuição de qui-quadrado. Valores altos desses testes indicam falta de ajustamento do modelo.

Cabe destacar que o uso apropriado do teste de Hosmer-Lemeshow requer um tamanho da amostra de pelo menos 50 casos para garantir que cada classe tenha pelo menos cinco observações. Nos 60 modelos de regressão estimados, os tamanhos das respectivas amostras (número de casos válidos) atenderam esse requisito, sendo todos acima do limite inferior de 50 casos válidos (ver tabela 4.4).

Retomando-se o caso concreto do modelo $Y_{A M B I}$ referente ao estrato 'BT/FO - médias empresas', constatou-se que todas as estimativas dos parâmetros 
da regressão foram estatisticamente significativas ao nível de $5 \%$, tendo sido usadas os testes de Wald e o da razão de verossimilhança como estatísticas de teste. A tabela 4.25, apresentada na seção seguinte deste capítulo, reúne os resultados da regressão logística para o modelo estimado e diversas medidas de qualidade de ajuste deste modelo. Observa-se que a capacidade preditiva do modelo, medida pelo Índice c aumentou em relação aos resultados do passo 1 da estimação Stepwise (Índice c $=0,708$, comparado com o Índice c no passo 1 , cujo valor foi 0,621$)$.

A estatística da log-verossimilhança, com o valor 110,667 também corroborou a significância global do modelo comparativamente ao modelo nulo (valor=124,210).

$\mathrm{Na}$ sequência, procedeu-se a análise dos resultados apresentados na tabela 4.11, com o objetivo de testar as hipóteses de pesquisa relativas a este modelo.

O quadro 4.5 sintetiza os resultados das hipóteses do modelo $Y_{A M B}$, referente ao estrato 'BT/FO - médias empresas'.

Quadro 4.5 - Resultados das hipóteses do modelo $Y_{A M B}$ referente ao estrato 'BT/FO médias empresas': análise de um caso concreto

\begin{tabular}{|c|c|c|}
\hline Hipótese & Descrição & Resultado \\
\hline H1.3 & $\begin{array}{l}\text { A cooperação com clientes e consumidores influencia a } \\
\text { apropriação de valor das inovações geradas em arranjos } \\
\text { cooperativos, pelos seus impactos ambientais. }\end{array}$ & Não confirmada \\
\hline H2.3 & $\begin{array}{l}\text { A cooperação com fornecedores influencia a apropriação de valor } \\
\text { das inovações geradas em arranjos cooperativos, pelos seus } \\
\text { impactos ambientais. }\end{array}$ & Não confirmada \\
\hline H3.3 & $\begin{array}{l}\text { A cooperação com concorrentes influencia a apropriação de valor } \\
\text { das inovações geradas em arranjos cooperativos, pelos seus } \\
\text { impactos ambientais. }\end{array}$ & Não confirmada \\
\hline H4.3 & $\begin{array}{l}\text { A cooperação com outra empresa do grupo influencia a } \\
\text { apropriação de valor das inovações geradas em arranjos } \\
\text { cooperativos, pelos seus impactos ambientais. }\end{array}$ & $\begin{array}{l}\text { Confirmada para o } \\
\text { estrato 'BT/FO -- } \\
\text { Médias empresas' }\end{array}$ \\
\hline H5.3 & $\begin{array}{l}\text { A cooperação com empresas de consultoria influencia a } \\
\text { apropriação de valor das inovações geradas em arranjos } \\
\text { cooperativos, pelos seus impactos ambientais. }\end{array}$ & Não confirmada \\
\hline H6.3 & $\begin{array}{l}\text { A cooperação com universidades e institutos de pesquisa } \\
\text { influencia a apropriação de valor das inovações geradas em } \\
\text { arranjos cooperativos, pelos seus impactos ambientais. }\end{array}$ & $\begin{array}{l}\text { Confirmada para o } \\
\text { estrato 'BT/FO - } \\
\text { Médias empresas' }\end{array}$ \\
\hline H7.3 & $\begin{array}{l}\text { A cooperação com centros de capacitação profissional e } \\
\text { assistência técnica influencia a apropriação de valor das } \\
\text { inovações geradas em arranjos cooperativos, pelos seus impactos } \\
\text { ambientais. }\end{array}$ & Não confirmada \\
\hline H8.3 & $\begin{array}{l}\text { A cooperação com instituições de ensaios e certificações } \\
\text { influencia a apropriação de valor das inovações geradas em } \\
\text { arranjos cooperativos, pelos seus impactos ambientais. }\end{array}$ & $\begin{array}{l}\text { Confirmada para o } \\
\text { estrato 'BT/FO - } \\
\text { Médias empresas' }\end{array}$ \\
\hline
\end{tabular}

Cabe ressaltar que todos os procedimentos relatados nesta seção para o caso concreto do modelo estimado $Y_{A M B I}$ referente ao estrato ' $\mathrm{BT} / \mathrm{FO}$ - médias 
empresas' foram realizados para os 60 modelos de estimação deste estudo empírico, como será apresentado seção 4.5.

\section{4. \\ Síntese dos aspectos metodológicos}

No quadro 4.6, a seguir, apresenta-se uma síntese dos aspectos metodológicos abordados neste capítulo.

Quadro 4.6 - Síntese dos aspectos metodológicos do estudo empírico

\begin{tabular}{|c|c|}
\hline Parâmetros & Base de dados secundários: Pintec 2014 \\
\hline Unidade de análise & Empresa \\
\hline Setores de atividades & Divisões da CNAE da indústria de transformação \\
\hline Área geográfica & Brasil \\
\hline $\begin{array}{l}\text { Organismo responsável } \\
\text { pela coleta e validação } \\
\text { dos dados }\end{array}$ & Diretoria de Pesquisas - DPE do IBGE. \\
\hline Tipo de dados & $\begin{array}{l}\text { Dados de pesquisa por amostragem probabilística. Amostra } \\
\text { estratificada desproporcional. }\end{array}$ \\
\hline $\begin{array}{l}\text { Periodicidade de } \\
\text { divulgação }\end{array}$ & $\begin{array}{l}\text { Trienal. Para este estudo, os dados referem-se ao período 2012- } \\
2014 .\end{array}$ \\
\hline Propósito da coleta & $\begin{array}{l}\text { Análise da influência da cooperação interorganizacional sobre a } \\
\text { apropriação de valor das inovações geradas em arranjos cooperativos } \\
\text { pelas empresas da indústria de transformação com } 10 \text { ou mais } \\
\text { pessoas ocupadas. }\end{array}$ \\
\hline Tamanho da amostra & $\begin{array}{l}\text { Amostra IBGE: estimadas } 6.091 \text { empresas da indústria de } \\
\text { transformação que implementaram inovações e com relações de } \\
\text { cooperação com outras organizações. } \\
\text { A amostra do estudo empírico totalizou } 1.520 \text { empresas respondentes } \\
\text { da Pintec } 2014 \text { (ver item 4.3.2). }\end{array}$ \\
\hline População-alvo & $\begin{array}{l}\text { Cadastro Central de Empresas - CEMPRE, do IBGE, delimitado pelo } \\
\text { âmbito da pesquisa. }\end{array}$ \\
\hline Qualidade dos dados & $\begin{array}{l}\text { Coeficiente de variação: } 12 \% \\
\text { Taxa de perda: } 15 \%\end{array}$ \\
\hline Acesso aos dados & $\begin{array}{l}\text { Acesso restrito aos microdados desidentificados da Pintec 2014, } \\
\text { mediante submissão de projeto de pesquisa ao Conselho de Sigilo do } \\
\text { IBGE. } \\
\text { Limitação do acesso aos microdados a duas solicitações por projeto. } \\
\text { Ou seja, em caso de necessidade de ajustes na programação na } \\
\text { linguagem SAS e novas rodadas, pode-se solicitar os dados somente } \\
\text { uma vez mais para uma segunda rodada. }\end{array}$ \\
\hline Análise dos dados & $\begin{array}{l}\text { Regressão logística com estimação Stepwise. } \\
\text { Testes estatísticos adotados: } \\
\text { - Capacidade preditiva do modelo medida pelo Índice c. } \\
\text { - Teste da razão de verossimilhança; } \\
\text { - Teste de Wald; } \\
\text { - Teste da log-verossimilhança; e } \\
\text { - Teste de Hosmer e Lemeshow. }\end{array}$ \\
\hline Pacote estatístico & $\begin{array}{l}\text { Statistical Analysis Software (SAS). } \\
\text { Disponibilizado pelo IBGE na Sala de Sigilo. }\end{array}$ \\
\hline
\end{tabular}

Fonte: Elaboração própria. 


\section{5.}

\section{Análise dos resultados}

Apresentam-se e discutem-se os resultados do estudo empírico em dois níveis:

(i) Análise da influência da cooperação interorganizacional sobre a apropriação de valor das inovações geradas pelas empresas da indústria de transformação, classificadas por agrupamento setorial (intensidade tecnológica/força do regime de apropriabilidade) e por tamanho (micro e pequenas; médias; e grandes empresas).

(ii) Análise comparativa dos resultados, evidenciando-se a influência da força do regime de apropriabilidade, da intensidade tecnológica setorial e do tamanho das empresas nos arranjos cooperativos e na escolha dos parceiros.

Partiu-se do pressuposto básico que em arranjos cooperativos as grandes empresas tendem a ter vantagens para alcançar seus objetivos em projetos de PD\&I, por possuírem uma grande base de conhecimento tecnológico e recursos próprios complementares, que proporcionam uma redução na incerteza do processo de inovação cooperativo. Por outro lado, as pequenas empresas têm uma estrutura mais flexível para gerenciar o compartilhamento de conhecimento e aceitar as mudanças em suas interfaces internas e externas, que trazem maiores incertezas em relação à expectativa na cooperação interorganizacional.

Isso posto, para o estudo empírico desenvolvido no âmbito da presente pesquisa, definiu-se como variável de controle o tamanho das empresas (por faixa de pessoal alocado), buscando-se investigar possíveis diferenças entre grandes, médias e empresas de menor porte na escolha de seus parceiros para cooperação em projetos de PD\&I.

Como já mencionado, a cooperação interorganizacional visando obter acesso a recursos externos para inovar pode aumentar a incerteza em relação a riscos de imitação, por exemplo. Empresas com forte regime de apropriabilidade teoricamente podem ter vantagens nesse sentido, independentemente de seu tamanho. 


\subsection{1.}

Análise da influência dos parceiros em arranjos cooperativos sobre a apropriação de valor das inovações geradas: agrupamento setorial AT/FO

As tabelas 4.13 a 4.17 , a seguir, apresentam as estimativas dos coeficientes de regressão em relação aos modelos estimados de regressão logística para empresas do agrupamento setorial AT/FO da indústria de transformação no Brasil que implementaram inovações em arranjos cooperativos com outras organizações no período de 2012 a 2014. Essas tabelas referem-se aos resultados deste agrupamento setorial, desagregados por tamanho das empresas, a saber: (i) micro e pequenas; (ii) médias; e (iii) grandes.

\subsubsection{1}

\section{Modelos estimados $Y_{M E R C}$}

Tabela 4.13 - Resultados das regressões logísticas para os modelos estimados $Y_{M E R C}$ referentes aos estratos AT/FO

\begin{tabular}{|c|c|c|c|c|}
\hline \multicolumn{5}{|c|}{ Modelos estimados $Y_{M E R C}$ referentes aos estratos AT/FO } \\
\hline Parâmetro & $\begin{array}{l}\text { Coeficiente } \\
\text { estimado }(\beta)\end{array}$ & $\begin{array}{l}\text { Erro } \\
\text { padrão }(\varepsilon)\end{array}$ & $\begin{array}{l}\text { Wald } \\
\text { Qui quadrado }\end{array}$ & $\begin{array}{l}\text { Significância } \\
\left(\mathrm{Pr}>\mathrm{X}^{2}\right)\end{array}$ \\
\hline \multicolumn{5}{|c|}{ Estrato AT/FO - Micro e pequenas empresas } \\
\hline Intercepto & 28,767 & 0,7415 & 150,506 & $0,0001^{* * *}$ \\
\hline \multicolumn{5}{|l|}{ Variável explanatória } \\
\hline$X_{\text {CLIE }}$ & 0,7283 & 0,2632 & 76,566 & $0,0057^{\star *}$ \\
\hline $\begin{array}{l}\text { Qualidade de ajuste do } \\
\text { modelo }\end{array}$ & & & Qui quadrado & $\begin{array}{l}\text { Significância } \\
\left(\mathrm{Pr}>\mathrm{X}^{2}\right)\end{array}$ \\
\hline $\begin{array}{l}\text { Capacidade preditiva } \\
\text { (Índice c) }\end{array}$ & 0,715 & & & \\
\hline Razão de verossimilhança & & & 82,827 & $0,0040^{* *}$ \\
\hline $\begin{array}{l}\text { Log-verossimilhança } \\
\text { (Modelo nulo) }\end{array}$ & 61,723 & & & \\
\hline $\begin{array}{l}\text { Log-verossimilhança } \\
\text { (Modelo estimado) }\end{array}$ & 53,440 & & & \\
\hline $\begin{array}{l}\text { Teste de Hosmer- } \\
\text { Lemeshow }\end{array}$ & & & 0,9996 & 0,6067 \\
\hline Número de casos & 58 & & & \\
\hline \multicolumn{5}{|c|}{ Estrato AT/FO - Médias empresas } \\
\hline Intercepto & 23,304 & 0,5583 & 174,230 & $<0,0001^{\star \star *}$ \\
\hline \multicolumn{5}{|l|}{ Variável explanatória } \\
\hline$X_{E M P R}$ & 0,4003 & 0,1678 & 56,931 & $0,0170^{*}$ \\
\hline $\begin{array}{l}\text { Qualidade de ajuste do } \\
\text { modelo }\end{array}$ & & & Qui quadrado & $\begin{array}{l}\text { Significância } \\
\left(\mathrm{Pr}>\mathrm{X}^{2}\right)\end{array}$ \\
\hline $\begin{array}{l}\text { Capacidade preditiva } \\
\text { (Índice c) }\end{array}$ & 0,634 & & & \\
\hline Razão de verossimilhança & & & 62,711 & $0,0123^{*}$ \\
\hline $\begin{array}{l}\text { Log-verossimilhança } \\
\text { (Modelo nulo) }\end{array}$ & 147,863 & & & \\
\hline $\begin{array}{l}\text { Log-verossimilhança } \\
\text { (Modelo estimado) }\end{array}$ & 141,592 & & & \\
\hline $\begin{array}{l}\text { Teste de Hosmer- } \\
\text { Lemeshow }\end{array}$ & & & 21,771 & 0,3367 \\
\hline Número de casos & 135 & & & \\
\hline
\end{tabular}


Tabela 4.13 - Resultados das regressões logísticas para os modelos estimados YMERC referentes aos estratos AT/FO (cont.)

\begin{tabular}{|c|c|c|c|c|}
\hline \multicolumn{5}{|c|}{ Modelos estimados $Y_{\text {MERC }}$ referentes aos estratos AT/FO } \\
\hline Parâmetro & $\begin{array}{l}\text { Coeficiente } \\
\text { estimado }(\beta)\end{array}$ & $\begin{array}{l}\text { Erro } \\
\text { padrão }(\varepsilon)\end{array}$ & $\begin{array}{l}\text { Wald } \\
\text { Qui quadrado }\end{array}$ & $\begin{array}{l}\text { Significância } \\
\left(\mathrm{Pr}>\mathrm{X}^{2}\right)\end{array}$ \\
\hline \multicolumn{5}{|c|}{ Estrato AT/FO - Grandes empresas } \\
\hline Intercepto & 35,961 & 0,8187 & 192.948 & $<0,0001^{* * *}$ \\
\hline \multicolumn{5}{|l|}{ Variável explanatória } \\
\hline$X_{\text {CLIE }}$ & 0,5221 & 0,2502 & 43,546 & $0,0369^{*}$ \\
\hline $\begin{array}{l}\text { Qualidade de ajuste do } \\
\text { modelo }\end{array}$ & & & Qui quadrado & $\begin{array}{l}\text { Significância } \\
\left(\mathrm{Pr}>\mathrm{X}^{2}\right)\end{array}$ \\
\hline $\begin{array}{l}\text { Capacidade preditiva } \\
\text { (Índice c) }\end{array}$ & 0,683 & & & \\
\hline Razão de verossimilhança & & & 48,346 & $0,0279^{*}$ \\
\hline $\begin{array}{l}\text { Log-verossimilhança } \\
\text { (Modelo nulo) }\end{array}$ & 72,141 & & & \\
\hline $\begin{array}{l}\text { Log-verossimilhança } \\
\text { (Modelo estimado) }\end{array}$ & 67,307 & & & \\
\hline $\begin{array}{l}\text { Teste de Hosmer- } \\
\text { Lemeshow }\end{array}$ & & & 29,979 & 0,2234 \\
\hline Número de casos & 113 & & & \\
\hline
\end{tabular}

Ao se analisar a qualidade de ajuste dos modelos estimados $Y_{M E R C}$, verificouse que as capacidades preditivas desses modelos, medidas pelo Índice c, variaram de 0,634 a 0,715. Como pode ser observado ainda, todas as estimativas dos parâmetros da regressão foram estatisticamente significativas ao nível de 5\%, tendo sido usadas a estatística de Wald e a razão de verossimilhança como estatísticas de teste.

As estatísticas da log-verosimilhança (valores de 53,440; 141,592; e 67,307), dos três modelos apresentados na tabela 4.13 também corroboram a significância global em comparação aos valores superiores observados nos respectivos modelos nulos.

$\mathrm{Na}$ sequência, procedeu-se a análise dos resultados apresentados na tabela 4.13 com o objetivo de testar as hipóteses de pesquisa relativas aos modelos estimados $Y_{M E R C}$ para estratos referentes aos estratos AT/FO (quadro 4.7). 
Quadro 4.7 - Resultados das hipóteses de pesquisa dos modelos $Y_{M E R C}$ referentes aos estratos AT/FO

\begin{tabular}{|c|c|c|}
\hline Hipótese & Descrição & Resultado \\
\hline H1.1 & $\begin{array}{l}\text { A cooperação com clientes e consumidores influencia } \\
\text { positivamente a apropriação de valor das inovações } \\
\text { geradas em arranjos cooperativos, pelos seus impactos } \\
\text { mercadológicos. }\end{array}$ & $\begin{array}{l}\text { Confirmada para dois estratos: } \\
\text { AT/FO - Micro e pequenas } \\
\text { empresas } \\
\text { AT/FO grandes emrpesas }\end{array}$ \\
\hline H2.1 & $\begin{array}{l}\text { A cooperação com fornecedores influencia positivamente a } \\
\text { apropriação de valor das inovações geradas em arranjos } \\
\text { cooperativos, pelos seus impactos mercadológicos. }\end{array}$ & Não confirmada \\
\hline H3.1 & $\begin{array}{l}\text { A cooperação com concorrentes influencia positivamente } \\
\text { a apropriação de valor das inovações geradas em arranjos } \\
\text { cooperativos, pelos seus impactos mercadológicos. }\end{array}$ & Não confirmada \\
\hline H4.1 & $\begin{array}{l}\text { A cooperação com outra empresa do grupo influencia } \\
\text { positivamente a apropriação de valor das inovações } \\
\text { geradas em arranjos cooperativos, pelos seus impactos } \\
\text { mercadológicos. }\end{array}$ & $\begin{array}{l}\text { Confirmada para o estrato } \\
\text { AT/FO - Médias empresas }\end{array}$ \\
\hline H5.1 & $\begin{array}{l}\text { A cooperação com empresas de consultoria influencia } \\
\text { positivamente a apropriação de valor das inovações } \\
\text { geradas em arranjos cooperativos, pelos seus impactos } \\
\text { mercadológicos. }\end{array}$ & Não confirmada \\
\hline H6.1 & $\begin{array}{l}\text { A cooperação com universidades e institutos de pesquisa } \\
\text { influencia positivamente a apropriação de valor das } \\
\text { inovações geradas em arranjos cooperativos, pelos seus } \\
\text { impactos mercadológicos. }\end{array}$ & Não confirmada \\
\hline H7.1 & $\begin{array}{l}\text { A cooperação com centros de capacitação profissional e } \\
\text { assistência técnica influencia positivamente a apropriação } \\
\text { de valor das inovações geradas em arranjos cooperativos, } \\
\text { pelos seus impactos mercadológicos. }\end{array}$ & Não confirmada \\
\hline H8.1 & $\begin{array}{l}\text { A cooperação com instituições de ensaios e certificações } \\
\text { influencia positivamente a apropriação de valor das } \\
\text { inovações geradas em arranjos cooperativos, pelos seus } \\
\text { impactos mercadológicos. }\end{array}$ & Não confirmada \\
\hline
\end{tabular}

Fonte: Elaboração própria.

Como ficou evidenciado na tabela 4.13, o modelo estimado $Y_{M E R C}$ referente ao estrato 'AT/FO - Micro e pequenas empresas' permitiu confirmar que o coeficiente estimado $(\beta)$ (valor $=0,7283)$ para a variável explanatória $X_{C L I E}$ foi estatisticamente significativo para um nível de significância de 5\%, confirmandose a hipótese H1.1 Essa hipótese também foi confirmada para o extrato das grandes empresas (coeficiente estimado $(\beta)=0,5221$ ).

A cooperação com outra empresa do grupo influenciando a apropriação de valor das inovações geradas em arranjos cooperativos pelas empresas de médio porte foi confirmada (H4.1), com o sinal do coeficiente coeficiente estimado $(\beta)$ (valor $=0,4003)$.

\subsubsection{2}

\section{Modelos estimados YPROD}

Apresentam-se na tabela 4.14, a seguir, os resultados obtidos dos coeficientes de regressão em relação aos modelos estimados YPRoD para micro e pequenas, médias e grandes empresas de transformação que implementaram 
inovações com cooperação interorganizacional em um ambiente setorial de alta tecnologia (AT) e com forte regime de apropriabilidade (FO).

Tabela 4.14 - Resultados das regressões logísticas para os modelos estimados YPROD referentes aos estratos AT/FO

\begin{tabular}{|c|c|c|c|c|}
\hline \multicolumn{5}{|c|}{ Modelos estimados $Y_{P R O D}$ referentes aos estratos AT/FO } \\
\hline Parâmetro & $\begin{array}{l}\text { Coeficiente } \\
\text { estimado }(\beta)\end{array}$ & $\begin{array}{l}\text { Erro } \\
\text { padrão }(\varepsilon)\end{array}$ & $\begin{array}{l}\text { Wald } \\
\text { Qui quadrado }\end{array}$ & $\begin{array}{l}\text { Significância } \\
\left(\mathrm{Pr}>\mathrm{X}^{2}\right)\end{array}$ \\
\hline \multicolumn{5}{|c|}{ Estrato AT/FO - Micro e pequenas empresas } \\
\hline Intercepto & 18,722 & 0,9292 & 40,596 & $0,0439^{*}$ \\
\hline \multicolumn{5}{|l|}{ Variável explanatória } \\
\hline$X_{\text {CONC }}$ & 0,5941 & 0,2667 & 49,630 & $0,0259^{*}$ \\
\hline $\begin{array}{l}\text { Qualidade de ajuste do } \\
\text { modelo }\end{array}$ & & & Qui quadrado & $\begin{array}{l}\text { Significância } \\
\left(\operatorname{Pr}>X^{2}\right)\end{array}$ \\
\hline $\begin{array}{l}\text { Capacidade preditiva } \\
\text { (Índice c) }\end{array}$ & 0,664 & & & \\
\hline Razão de verossimilhança & & & 55,803 & $0,0182^{*}$ \\
\hline $\begin{array}{l}\text { Log-verossimilhança } \\
\text { (Modelo nulo) }\end{array}$ & 80,336 & & & \\
\hline $\begin{array}{l}\text { Log-verossimilhança } \\
\text { (Modelo estimado) }\end{array}$ & 74,756 & & & \\
\hline $\begin{array}{ll}\text { Teste de Hosmer- } \\
\text { Lemeshow }\end{array}$ & & & 18,330 & 0,3999 \\
\hline Número de casos & 58 & & & \\
\hline \multicolumn{5}{|c|}{ Estrato AT/FO - Médias empresas } \\
\hline Intercepto & 12,555 & 0,4203 & 85,014 & $0,0035^{\star *}$ \\
\hline \multicolumn{5}{|l|}{ Variável explanatória } \\
\hline$X_{E M P R}$ & 0,3413 & 0,1351 & 63,783 & $0,0116^{*}$ \\
\hline $\begin{array}{l}\text { Qualidade de ajuste do } \\
\text { modelo }\end{array}$ & & $\begin{array}{l}\text { Qui } \\
\text { quadrado }\end{array}$ & & $\begin{array}{l}\text { Significância } \\
\left(\mathrm{Pr}>\mathrm{X}^{2}\right)\end{array}$ \\
\hline $\begin{array}{l}\text { Capacidade preditiva } \\
\text { (Índice c) }\end{array}$ & 0,613 & & & \\
\hline Razão de verossimilhança & & 66,467 & & $0,0099^{* *}$ \\
\hline $\begin{array}{l}\text { Log-verossimilhança } \\
\text { (Modelo nulo) }\end{array}$ & 184,467 & & & \\
\hline $\begin{array}{l}\text { Log-verossimilhança } \\
\text { (Modelo estimado) }\end{array}$ & 177,820 & & & \\
\hline $\begin{array}{l}\text { Teste de Hosmer- } \\
\text { Lemeshow }\end{array}$ & & 28,216 & & 0,2440 \\
\hline Número de casos & 135 & & & \\
\hline \multicolumn{5}{|c|}{ Estrato AT/FO - Grandes empresas } \\
\hline Intercepto & 19,885 & 0,6844 & 84,422 & $0,0037^{\star *}$ \\
\hline \multicolumn{5}{|l|}{ Variável explanatória } \\
\hline$X_{C C A P}$ & 0,4182 & 0,2030 & 42,423 & $0,0394^{*}$ \\
\hline $\begin{array}{l}\text { Qualidade de ajuste do } \\
\text { modelo }\end{array}$ & & $\begin{array}{l}\text { Qui } \\
\text { quadrado }\end{array}$ & & $\begin{array}{l}\text { Significância } \\
\left(\operatorname{Pr}>X^{2}\right)\end{array}$ \\
\hline $\begin{array}{l}\text { Capacidade preditiva } \\
\text { (Índice c) }\end{array}$ & 0,614 & & & \\
\hline Razão de verossimilhança & & 45,876 & & $0,0322^{*}$ \\
\hline $\begin{array}{l}\text { Log-verossimilhança } \\
\text { (Modelo nulo) }\end{array}$ & 144,310 & & & \\
\hline $\begin{array}{l}\text { Log-verossimilhança } \\
\text { (Modelo estimado) }\end{array}$ & 139,722 & & & \\
\hline $\begin{array}{l}\text { Teste de Hosmer- } \\
\text { Lemeshow }\end{array}$ & & 0,2457 & & 0,8844 \\
\hline Número de casos & 113 & & & \\
\hline
\end{tabular}

Analisando-se a qualidade de ajuste dos modelos estimados YPROD, constatou-se que as capacidades preditivas dos modelos, medidas pelo Índice c, variaram em média em torno de 0,630. Cabe ressaltar que todas as estimativas dos parâmetros da regressão foram estatisticamente significativas ao nível de 5\%, 
tendo sido usadas a estatística de Wald e a razão de verossimilhança como estatísticas de teste.

Adicionalmente, as estatísticas da log-verosimilhança (valores de 74,756; 177,820; e 139,722) corroboraram a significância global dos modelos comparativamente aos valores superiores observados nos modelos nulos.

$\mathrm{Na}$ sequência, procedeu-se a análise dos resultados apresentados na tabela 4.14 , visando testar as hipóteses de pesquisa relativas aos modelos estimados $Y_{P R O D}$ para estratos referentes aos estratos AT/FO (quadro 4.8).

Quadro 4.8 - Resultados das hipóteses de pesquisa dos modelos $Y_{P R O D}$ referentes aos estratos AT/FO

\begin{tabular}{|c|c|c|}
\hline Hipótese & Descrição & Resultado \\
\hline H1.2 & $\begin{array}{l}\text { A cooperação com clientes e consumidores influencia } \\
\text { positivamente a apropriação de valor das inovações geradas } \\
\text { em arranjos cooperativos, pelos seus impactos na produção. }\end{array}$ & Não confirmada \\
\hline H2.2 & $\begin{array}{l}\text { A cooperação com fornecedores influencia positivamente a } \\
\text { apropriação de valor das inovações geradas em arranjos } \\
\text { cooperativos, pelos seus impactos na produção. }\end{array}$ & Não confirmada \\
\hline H3.2 & $\begin{array}{l}\text { A cooperação com concorrentes influencia positivamente a } \\
\text { apropriação de valor das inovações geradas em arranjos } \\
\text { cooperativos, pelos seus impactos na produção. }\end{array}$ & $\begin{array}{l}\text { Confirmada para o estrato } \\
\text { AT/FO - Micro e pequenas } \\
\text { empresas }\end{array}$ \\
\hline H4.2 & $\begin{array}{l}\text { A cooperação com outra empresa do grupo influencia } \\
\text { positivamente a apropriação de valor das inovações geradas } \\
\text { em arranjos cooperativos, pelos seus impactos na produção. }\end{array}$ & $\begin{array}{l}\text { Confirmada para o estrato } \\
\text { AT/FO - Médias empresas }\end{array}$ \\
\hline H5.2 & $\begin{array}{l}\text { A cooperação com empresas de consultoria influencia } \\
\text { positivamente a apropriação de valor das inovações geradas } \\
\text { em arranjos cooperativos, pelos seus impactos na produção. }\end{array}$ & Não confirmada \\
\hline H6.2 & $\begin{array}{l}\text { A cooperação com universidades e institutos de pesquisa } \\
\text { influencia positivamente a apropriação de valor das } \\
\text { inovações geradas em arranjos cooperativos, pelos seus } \\
\text { impactos na produção. }\end{array}$ & Não confirmada \\
\hline H7.2 & $\begin{array}{l}\text { A cooperação com centros de capacitação profissional e } \\
\text { assistência técnica influencia positivamente a apropriação de } \\
\text { valor das inovações geradas em arranjos cooperativos, pelos } \\
\text { seus impactos na produção. }\end{array}$ & $\begin{array}{l}\text { Confirmada para o estrato } \\
\text { AT/FO - Grandes empresas }\end{array}$ \\
\hline H8.2 & $\begin{array}{l}\text { A cooperação com instituições de ensaios e certificações } \\
\text { influencia positivamente a apropriação de valor das } \\
\text { inovações geradas em arranjos cooperativos, pelos seus } \\
\text { impactos na produção. }\end{array}$ & Não confirmada \\
\hline
\end{tabular}

Fonte: Elaboração própria.

Como pode ser observado na tabela 4.14, o modelo estimado $Y_{P R O D}$ referente ao estrato 'AT/FO - Micro e pequenas empresas' permitiu confirmar que o coeficiente estimado $(0,5941)$ para a variável explanatória $X_{C O N C}$ foi estatisticamente significativo para um nível de significância de 5\%. Assim, rejeitou-se a hipótese nula de que não existia relação entre a referida variável explanatória e a variável dependente (i.e., apropriação de valor expressa por impactos na produção geradas pelas inovações das micro e pequenas empresas em arranjos cooperativos para projetos de PD\&I). 
A cooperação com outra empresa do grupo influenciando positivamente a apropriação de valor das inovações geradas em arranjos cooperativos (expressa pelos seus impactos na produção) foi confirmada com o sinal do coeficiente estimado $(\beta)$ positivo (valor=0,3413) para as empresas de médio porte (hipótese H4.2).

Finalmente, a hipótese H7.2 foi confirmada para grandes empresas do agrupamento AT/FO pelo sinal positivo do coeficiente de regressão $(0,4182)$.

\subsubsection{3 \\ Modelos estimados $Y_{A M B I}$}

A tabela 4.15 sumariza os resultados das regressões logísticas para os modelos estimados $Y_{A M B}$ referentes aos estratos do agrupamento setorial AT/FO, que integram a amostra deste estudo empírico.

Para o extrato das micro e pequenas empresas, não foi possível estimar um modelo de regressão pelos resultados iniciais da aplicação do procedimento Stepwise, que indicaram que nenhum efeito (adicional) pela entrada das variáveis explanatórias no modelo atenderia ao nível de significância de 5\%. Já para os outros dois extratos a avaliação da qualidade de ajuste dos modelos estimados $Y_{A M B I}$ apontou que as capacidades preditivas desses modelos, medidas pelo Índice c, chegaram a 0,687 ('AT/FO - Médias empresas') e 0,613 ('AT/FO - Grandes empresas').

Tabela 4.15 - Resultados das regressões logísticas para os modelos estimados $Y_{A M B I}$ referentes aos estratos AT/FO

\begin{tabular}{|c|c|c|c|c|}
\hline \multicolumn{5}{|c|}{ Modelos estimados $Y_{A M B I}$ referentes aos estratos AT/FO } \\
\hline Parâmetro & $\begin{array}{l}\text { Coeficiente } \\
\text { estimado }(\beta)\end{array}$ & $\begin{array}{l}\text { Erro } \\
\text { padrão }(\varepsilon)\end{array}$ & $\begin{array}{l}\text { Wald } \\
\text { Qui quadrado }\end{array}$ & $\begin{array}{l}\text { Significância } \\
\left(\operatorname{Pr}>X^{2}\right)\end{array}$ \\
\hline \multicolumn{5}{|c|}{ Estrato AT/FO - Micro e pequenas empresas } \\
\hline Intercepto & 13,437 & 0,3241 & 171,846 & $<0,0001^{\star \star \star}$ \\
\hline \multicolumn{5}{|l|}{ Variável explanatória } \\
\hline \multicolumn{5}{|c|}{$\begin{array}{l}\text { Nenhum efeito (adicional) pela entrada das variáveis explanatórias no modelo atendeu ao nível de } \\
\text { significância de } 5 \% \text {. }\end{array}$} \\
\hline $\begin{array}{l}\text { Qualidade de ajuste do } \\
\text { modelo }\end{array}$ & & & Qui quadrado & $\begin{array}{l}\text { Significância } \\
\left(\operatorname{Pr}>X^{2}\right)\end{array}$ \\
\hline $\begin{array}{l}\text { Capacidade preditiva } \\
\text { (Índice c) }\end{array}$ & - & & & \\
\hline Razão de verossimilhança & - & & & - \\
\hline $\begin{array}{l}\text { Log-verossimilhança } \\
\text { (modelo nulo) }\end{array}$ & 59,139 & & & \\
\hline $\begin{array}{l}\text { Log-verossimilhança } \\
\text { (modelo estimado) }\end{array}$ & - & & & \\
\hline $\begin{array}{l}\text { Teste de Hosmer- } \\
\text { Lemeshow }\end{array}$ & - & & & - \\
\hline Número de casos & 58 & & & \\
\hline
\end{tabular}


Tabela 4.15 - Resultados das regressões logísticas para os modelos estimados $Y_{A M B I}$ referentes aos estratos AT/FO (cont.)

\begin{tabular}{|c|c|c|c|c|}
\hline \multicolumn{5}{|c|}{ Modelos estimados $Y_{A M B I}$ referentes aos estratos AT/FO } \\
\hline Parâmetro & $\begin{array}{l}\text { Coeficiente } \\
\text { estimado }(\beta)\end{array}$ & $\begin{array}{l}\text { Erro } \\
\text { padrão }(\varepsilon)\end{array}$ & $\begin{array}{l}\text { Wald } \\
\text { Qui quadrado }\end{array}$ & $\begin{array}{l}\text { Significância } \\
\left(\operatorname{Pr}>X^{2}\right)\end{array}$ \\
\hline \multicolumn{5}{|c|}{ Estrato AT/FO - Médias empresas } \\
\hline Intercepto & 0,3243 & 0,4712 & 0,4739 & 0,4912 \\
\hline \multicolumn{5}{|l|}{ Variável explanatória } \\
\hline$X_{C E R T}$ & 0,5987 & 0,1744 & 117,905 & $0,0006^{* * *}$ \\
\hline $\begin{array}{l}\text { Qualidade de ajuste do } \\
\text { modelo }\end{array}$ & & & Qui quadrado & $\begin{array}{l}\text { Significância } \\
\left(\operatorname{Pr}>X^{2}\right)\end{array}$ \\
\hline $\begin{array}{l}\text { Capacidade preditiva } \\
\text { (Índice c) }\end{array}$ & 0,687 & & & \\
\hline Razão de verossimilhança & & & 118,759 & $0,0004^{\star * *}$ \\
\hline $\begin{array}{l}\text { Log-verossimilhança } \\
\text { (Modelo nulo) }\end{array}$ & 143,021 & & & \\
\hline $\begin{array}{l}\text { Log-verossimilhança } \\
\text { (Modelo estimado) }\end{array}$ & 130,353 & & & \\
\hline $\begin{array}{l}\text { Teste de Hosmer- } \\
\text { Lemeshow }\end{array}$ & & & 24,234 & 0,2977 \\
\hline Número de casos & 135 & & & \\
\hline \multicolumn{5}{|c|}{ Estrato AT/FO - Grandes empresas } \\
\hline Intercepto & 0,6307 & 0,3688 & 29,248 & 0,0872 \\
\hline \multicolumn{5}{|l|}{ Variável explanatória } \\
\hline$X_{\text {CLIE }}$ & 0,3780 & 0,1471 & 66,078 & $0,0102^{*}$ \\
\hline $\begin{array}{l}\text { Qualidade de ajuste do } \\
\text { modelo }\end{array}$ & & & Qui quadrado & $\begin{array}{l}\text { Significância } \\
\left(\operatorname{Pr}>X^{2}\right)\end{array}$ \\
\hline $\begin{array}{l}\text { Capacidade preditiva } \\
\text { (Índice c) }\end{array}$ & 0,638 & & & \\
\hline Razão de verossimilhança & & & 69,557 & $0,0084^{* *}$ \\
\hline $\begin{array}{l}\text { Log-verossimilhança } \\
\text { (modelo nulo) }\end{array}$ & 155,579 & & & \\
\hline $\begin{array}{l}\text { Log-verossimilhança } \\
\text { (modelo estimado) }\end{array}$ & 148,623 & & & \\
\hline $\begin{array}{l}\text { Teste de Hosmer- } \\
\text { Lemeshow }\end{array}$ & & & 16,570 & 0,4367 \\
\hline Número de casos & 113 & & & \\
\hline
\end{tabular}

Como pode ser visto na tabela 4.15 , todas as estimativas dos parâmetros da regressão desses dois modelos foram estatisticamente significativas ao nível de $5 \%$, tendo sido usadas a estatística de Wald e a razão de verossimilhança como estatísticas de teste. As estatísticas da log-verosimilhança (valores de 130,353; e 148,623) confirmaram ainda a significância global dos modelos em comparação aos valores superiores observados nos modelos nulos.

$\mathrm{Na}$ sequência, procedeu-se a análise dos resultados apresentados na tabela 4.16 para testar as hipóteses de pesquisa relativas aos modelos estimados $Y_{A M B I}$ para os três estratos do agrupamento setorial AT/FO (quadro 4.9). 
Quadro 4.9 - Resultados das hipóteses de pesquisa dos modelos $Y_{A M B I}$ referentes aos estratos AT/FO

\begin{tabular}{|c|c|c|}
\hline Hipótese & Descrição & Resultado \\
\hline H1.3 & $\begin{array}{l}\text { A cooperação com clientes e consumidores influencia } \\
\text { positivamente a apropriação de valor das inovações geradas } \\
\text { em arranjos cooperativos, pelos seus impactos ambientais. }\end{array}$ & $\begin{array}{l}\text { Confirmada para o extrato: } \\
\text { AT/FO - } \quad \text { Grandes } \\
\text { empresas. }\end{array}$ \\
\hline $\mathrm{H} 2.3$ & $\begin{array}{l}\text { A cooperação com fornecedores influencia positivamente a } \\
\text { apropriação de valor das inovações geradas em arranjos } \\
\text { cooperativos, pelos seus impactos ambientais. }\end{array}$ & Não confirmada \\
\hline H3.3 & $\begin{array}{l}\text { A cooperação com concorrentes influencia positivamente a } \\
\text { apropriação de valor das inovações geradas em arranjos } \\
\text { cooperativos, pelos seus impactos ambientais. }\end{array}$ & Não confirmada \\
\hline H4.3 & $\begin{array}{l}\text { A cooperação com outra empresa do grupo influencia } \\
\text { positivamente a apropriação de valor das inovações geradas } \\
\text { em arranjos cooperativos, pelos seus impactos ambientais. }\end{array}$ & Não confirmada \\
\hline H5.3 & $\begin{array}{l}\text { A cooperação com empresas de consultoria influencia } \\
\text { positivamente a apropriação de valor das inovações geradas } \\
\text { em arranjos cooperativos, pelos seus impactos ambientais. }\end{array}$ & Não confirmada \\
\hline H6.3 & $\begin{array}{l}\text { A cooperação com universidades e institutos de pesquisa } \\
\text { influencia positivamente a apropriação de valor das inovações } \\
\text { geradas em arranjos cooperativos, pelos seus impactos } \\
\text { ambientais. }\end{array}$ & Não confirmada \\
\hline H7.3 & $\begin{array}{l}\text { A cooperação com centros de capacitação profissional e } \\
\text { assistência técnica influencia positivamente a apropriação de } \\
\text { valor das inovações geradas em arranjos cooperativos, pelos } \\
\text { seus impactos ambientais }\end{array}$ & Não confirmada \\
\hline H8.3 & $\begin{array}{l}\text { A cooperação com instituições de ensaios e certificações } \\
\text { influencia positivamente a apropriação de valor das inovações } \\
\text { geradas em arranjos cooperativos, pelos seus impactos } \\
\text { ambientais. }\end{array}$ & $\begin{array}{l}\text { Confirmada para o extrato: } \\
\text { AT/FO - Médias empresas. }\end{array}$ \\
\hline
\end{tabular}

O modelo estimado $Y_{A M B I}$ referente ao estrato 'AT/FO - Médias empresas' permitiu confirmar que o coeficiente estimado $(0,5987)$ para a variável explanatória $X_{C E R T}$ foi estatisticamente significativo para um nível de significância de 5\%. Rejeitou-se assim a hipótese nula de que não existia relação entre a referida variável explanatória e a variável dependente (i.e., apropriação de valor expressa por impactos ambientiais das inovações geradas em arranjos cooperativos pelas médias empresas). Já a influência positiva da cooperação com clientes e consumidores sobre a apropriação de valor das inovações geradas por empresas de grande porte em arranjos cooperativos foi confirmada (H1.3) pelo valor positivo do coeficiente estimado $(\beta)$ igual a 0,3780 .

\subsubsection{4}

\section{Modelos estimados $Y_{\text {socl }}$}

A tabela 4.16 sumariza os resultados das regressões logísticas para os modelos estimados $Y_{\text {Socl }}$ referentes aos estratos do agrupamento setorial AT/FO, que integram a amostra deste estudo empírico 
Tabela 4.16 - Resultados das regressões logísticas para os modelos estimados $Y_{s o C l}$ referentes aos estratos AT/FO

\begin{tabular}{|c|c|c|c|c|}
\hline \multicolumn{5}{|c|}{ Modelos estimados $Y_{\text {socl }}$ referentes aos estratos AT/FO } \\
\hline Parâmetro & $\begin{array}{l}\text { Coeficiente } \\
\text { estimado }(\beta)\end{array}$ & $\begin{array}{l}\text { Erro } \\
\text { padrão }(\varepsilon)\end{array}$ & $\begin{array}{l}\text { Wald } \\
\text { Qui quadrado }\end{array}$ & $\begin{array}{l}\text { Significância } \\
\left(\operatorname{Pr}>X^{2}\right)\end{array}$ \\
\hline \multicolumn{5}{|c|}{ Estrato AT/FO - Micro e pequenas empresas } \\
\hline Intercepto & 15,786 & 0,5560 & 80,601 & $0,0045^{\star *}$ \\
\hline \multicolumn{5}{|l|}{ Variável explanatória } \\
\hline$X_{C L I E}$ & 0,5349 & 0,2313 & 53,501 & $0,0207^{*}$ \\
\hline $\begin{array}{l}\text { Qualidade de ajuste do } \\
\text { modelo }\end{array}$ & & & Qui quadrado & $\begin{array}{l}\text { Significância } \\
\left(\operatorname{Pr}>\mathrm{X}^{2}\right)\end{array}$ \\
\hline $\begin{array}{l}\text { Capacidade preditiva } \\
\text { (Índice c) }\end{array}$ & 0,649 & & & \\
\hline Razão de verossimilhança & & & 56,788 & $0,0172^{*}$ \\
\hline $\begin{array}{l}\text { Log-verossimilhança } \\
\text { (Modelo nulo) }\end{array}$ & 76,992 & & & \\
\hline $\begin{array}{l}\text { Log-verossimilhança } \\
\text { (Modelo estimado) }\end{array}$ & 71,313 & & & \\
\hline Teste de Hosmer-Lemeshow & & & 11,729 & 0,5563 \\
\hline Número de casos & 58 & & & \\
\hline \multicolumn{5}{|c|}{ Estrato AT/FO - Médias empresas } \\
\hline Intercepto & 10,116 & 0,4088 & 61,234 & $0,0133^{*}$ \\
\hline \multicolumn{5}{|l|}{ Variável explanatória } \\
\hline$X_{E M P R}$ & 0,2985 & 0,1328 & 50,536 & $0,0246^{*}$ \\
\hline $\begin{array}{l}\text { Qualidade de ajuste do } \\
\text { modelo }\end{array}$ & & & Qui quadrado & $\begin{array}{l}\text { Significância } \\
\left(\operatorname{Pr}>X^{2}\right)\end{array}$ \\
\hline $\begin{array}{l}\text { Capacidade preditiva } \\
\text { (Índice c) }\end{array}$ & 0,596 & & & \\
\hline Razão de verossimilhança & & & 52,060 & $0,0225^{*}$ \\
\hline $\begin{array}{l}\text { Log-verossimilhança } \\
\text { (Modelo nulo) }\end{array}$ & 185,896 & & & \\
\hline $\begin{array}{l}\text { Log-verossimilhança } \\
\text { (Modelo estimado) }\end{array}$ & 180,690 & & & \\
\hline Teste de Hosmer-Lemeshow & & & 93,684 & $0,0092^{* *}$ \\
\hline Número de casos & 135 & & & \\
\hline \multicolumn{5}{|c|}{ Estrato AT/FO - Grandes empresas } \\
\hline Intercepto & 20,078 & 0,4633 & 187,807 & $<0,0001^{\star \star \star}$ \\
\hline \multicolumn{5}{|l|}{ Variável explanatória } \\
\hline$X_{C L I E}$ & 0,4306 & 0,1588 & 73,515 & $0,0067^{* *}$ \\
\hline $\begin{array}{l}\text { Qualidade de ajuste do } \\
\text { modelo }\end{array}$ & & & Qui quadrado & $\begin{array}{l}\text { Significância } \\
\left(P r>X^{2}\right)\end{array}$ \\
\hline $\begin{array}{l}\text { Capacidade preditiva } \\
\text { (Índice c) }\end{array}$ & 0,657 & & & \\
\hline Razão de verossimilhança & & & 76,379 & $0,0057^{* *}$ \\
\hline $\begin{array}{l}\text { Log-verossimilhança } \\
\text { (modelo nulo) }\end{array}$ & 132,780 & & & \\
\hline $\begin{array}{l}\text { Log-verossimilhança } \\
\text { (modelo estimado) }\end{array}$ & 125,143 & & & \\
\hline Teste de Hosmer-Lemeshow & & & 0,3691 & 0,8315 \\
\hline Número de casos & 113 & & & \\
\hline
\end{tabular}

A avaliação da qualidade de ajuste dos três modelos $Y_{\text {socl }}$ apontou que as capacidades preditivas desses modelos, medidas pelo Índice c, se situaram entre os valores de 0,596 e 0,657 . 
Como pode ser observado na tabela 4.16, todas as estimativas dos parâmetros da regressão desses três modelos foram estatisticamente significativas ao nível de 5\%, tendo sido usadas a estatística de Wald e a razão de verossimilhança como estatísticas de teste. Além disso, as estatísticas da logverosimilhança (valores de 71,313; 180,690; e 125,143, respectivamente) confirmaram a significância global desses modelos em comparação aos valores superiores observados nos modelos nulos.

Na sequência, procedeu-se à análise dos resultados apresentados na tabela 4.16, visando testar as hipóteses de pesquisa relativas aos modelos estimados $Y_{S O C I}$ para os estratos AT/FO (quadro 4.10).

Quadro 4.10 - Resultados das hipóteses de pesquisa dos modelos $Y_{S O C I}$ referentes aos estratos AT/FO

\begin{tabular}{|c|c|c|}
\hline Hipótese & Descrição & Resultado \\
\hline H1.4 & $\begin{array}{l}\text { A cooperação com clientes e consumidores } \\
\text { influencia positivamente a apropriação de valor das } \\
\text { inovações geradas em arranjos cooperativos, pelos } \\
\text { seus impactos sociais. }\end{array}$ & $\begin{array}{l}\text { Confirmada para dois estratos: } \\
\text { AT/FO - Micro e pequenas empresas } \\
\text { AT/FO grandes empresas }\end{array}$ \\
\hline H2.4 & $\begin{array}{l}\text { A cooperação com fornecedores influencia } \\
\text { positivamente a apropriação de valor das inovações } \\
\text { geradas em arranjos cooperativos, pelos seus } \\
\text { impactos sociais. }\end{array}$ & Não confirmada \\
\hline H3.4 & $\begin{array}{l}\text { A cooperação com concorrentes influencia } \\
\text { positivamente a apropriação de valor das inovações } \\
\text { geradas em arranjos cooperativos, pelos seus } \\
\text { impactos sociais. }\end{array}$ & Não confirmada \\
\hline H4.4 & $\begin{array}{l}\text { A cooperação com outra empresa do grupo influencia } \\
\text { positivamente a apropriação de valor das inovações } \\
\text { geradas em arranjos cooperativos, pelos seus } \\
\text { impactos sociais. }\end{array}$ & $\begin{array}{l}\text { Confirmada para o estrato } \\
\text { AT/FO - Médias empresas }\end{array}$ \\
\hline H5.4 & $\begin{array}{l}\text { A cooperação com empresas de consultoria } \\
\text { influencia positivamente a apropriação de valor das } \\
\text { inovações geradas em arranjos cooperativos, pelos } \\
\text { seus impactos sociais. }\end{array}$ & Não confirmada \\
\hline H6.4 & $\begin{array}{l}\text { A cooperação com universidades e institutos de } \\
\text { pesquisa influencia positivamente a apropriação de } \\
\text { valor das inovações geradas em arranjos } \\
\text { cooperativos, pelos seus impactos sociais. }\end{array}$ & Não confirmada \\
\hline H7.4 & $\begin{array}{l}\text { A cooperação com centros de capacitação } \\
\text { profissional e assistência técnica influencia } \\
\text { positivamente a apropriação de valor das inovações } \\
\text { geradas em arranjos cooperativos, pelos seus } \\
\text { impactos socais. }\end{array}$ & Não confirmada \\
\hline H8.4 & $\begin{array}{l}\text { A cooperação com instituições de ensaios e } \\
\text { certificações influencia positivamente a apropriação } \\
\text { de valor das inovações geradas em arranjos } \\
\text { cooperativos, pelos seus impactos sociais. }\end{array}$ & Não confirmada \\
\hline
\end{tabular}

Fonte: Elaboração própria.

Como pode ser observado na tabela 4.16, o modelo estimado $Y_{S O C I}$ referente ao estrato 'AT/FO - Micro e pequenas empresas' permitiu confirmar que o coeficiente estimado $(\beta)$ igual a 0,5349 para a variável explanatória $X_{C L I E}$ foi estatisticamente significativo para um nível de significância de 5\%, confirmando- 
se assim a hipótese H1.4. Esta hipótese também foi confirmada para o extrato das grandes empresas (coeficiente estimado $(\beta)=0,4306$ ).

A cooperação com outra empresa do grupo influenciando a apropriação de valor das inovações geradas em arranjos cooperativos, expressa pelos seus impactos sociais foi confirmada (H4.4), com o sinal do coeficiente de regressão positivo $(0,2985)$ para as empresas de médio porte do agrupamento AT/FO.

\subsubsection{5}

\section{Modelos estimados $Y_{R E G U}$}

A seguir, na tabela 4.17, apresentam-se os resultados obtidos dos coeficientes de regressão em relação aos modelos estimados $Y_{R E G U}$ para os três estratos do agrupamento setorial AT/FO.

A avaliação da qualidade de ajuste dos três modelos $Y_{R E G U}$ indicou que as capacidades preditivas desses modelos, medidas pelo Índice c, variaram na faixa de 0,596 a 0,819 , sendo a capacidade maior observada no modelo do estrato ‘AT/FO - Micro e pequenas empresas' e a inferior no modelo do estrato 'AT/FO - Médias empresas'

Como pode ser constatado na tabela 4.17, todas as estimativas dos parâmetros da regressão desses três modelos foram estatisticamente significativas ao nível de 5\%, tendo sido usadas a estatística de Wald e a razão de verossimilhança como estatísticas de teste.

Além disso, as estatísticas da log-verosimilhança (valores de 59,225; 180,522; e 104,650, respectivamente) corroboraram a significância global desses modelos em comparação aos valores superiores observados nos modelos nulos.

A análise dos resultados apresentados na tabela 4.17 para testar as hipóteses de pesquisa relativas aos modelos estimados $Y_{R E G U}$ para os estratos $\mathrm{AT} / \mathrm{FO}$ revelou a confirmação das hipóteses H2.5, H4.5 e H5.5, conforme mostrado no quadro 4.11 (apresentado ao final deste item).

O modelo estimado $Y_{R E G U}$ referente ao estrato 'AT/FO - Médias empresas' permitiu confirmar que o coeficiente estimado $(\beta)$ igual a 0,9542 para a variável explanatória $X_{F O R N}$ foi estatisticamente significativo para um nível de significância de 5\%. Confirmou-se assim a hipótese H2.5 para este estrato. Mesma hipótese foi confirmada para o estrato das médias empresas, pelo valor do coeficiente de regressão igual a 0,3238. 
Tabela 4.17 - Resultados das regressões logísticas para os modelos estimados $Y_{R E G U}$ referentes aos estratos AT/FO

\begin{tabular}{|c|c|c|c|c|}
\hline \multicolumn{5}{|c|}{ Modelos estimados $Y_{R E G U}$ referentes aos estratos AT/FO } \\
\hline Parâmetro & $\begin{array}{l}\text { Coeficiente } \\
\text { estimado }(\beta)\end{array}$ & $\begin{array}{l}\text { Erro } \\
\text { padrão }(\varepsilon)\end{array}$ & $\begin{array}{l}\text { Wald } \\
\text { Qui quadrado }\end{array}$ & $\begin{array}{l}\text { Significância } \\
\left(\mathrm{Pr}>\mathrm{X}^{2}\right)\end{array}$ \\
\hline \multicolumn{5}{|c|}{ Estrato AT/FO - Micro e pequenas empresas } \\
\hline Intercepto & 38,240 & 10,682 & 128,145 & $0,0003^{* * *}$ \\
\hline \multicolumn{5}{|l|}{ Variável explanatória } \\
\hline$X_{\text {FORN }}$ & 0,9542 & 0,3420 & 77,862 & $0,0053^{* *}$ \\
\hline$X_{\text {CONS }}$ & 0,5976 & 0,2683 & 49,595 & $0,0259^{*}$ \\
\hline $\begin{array}{l}\text { Qualidade de ajuste do } \\
\text { modelo }\end{array}$ & & & Qui quadrado & $\begin{array}{l}\text { Significância } \\
\left(\mathrm{Pr}>\mathrm{X}^{2}\right)\end{array}$ \\
\hline $\begin{array}{l}\text { Capacidade preditiva } \\
\text { (Índice c) }\end{array}$ & 0,819 & & & \\
\hline Razão de verossimilhança & & & 177,676 & $0,0001^{* * *}$ \\
\hline $\begin{array}{l}\text { Log-verossimilhança } \\
\text { (modelo nulo) }\end{array}$ & 76,992 & & & \\
\hline $\begin{array}{l}\text { Log-verossimilhança } \\
\text { (modelo estimado) }\end{array}$ & 59,225 & & & \\
\hline $\begin{array}{l}\text { Teste de Hosmer- } \\
\text { Lemeshow }\end{array}$ & & & 69,465 & 0,3258 \\
\hline Número de casos & 58 & & & \\
\hline \multicolumn{5}{|c|}{ Estrato AT/FO - Médias empresas } \\
\hline Intercepto & 0,8819 & 0,3496 & 63,645 & 0,0116 \\
\hline \multicolumn{5}{|l|}{ Variável explanatória } \\
\hline$X_{\text {FORN }}$ & 0,3228 & 0,1411 & 52,368 & 0,0221 \\
\hline $\begin{array}{l}\text { Qualidade de ajuste do } \\
\text { modelo }\end{array}$ & & & Qui quadrado & $\begin{array}{l}\text { Significância } \\
\left(\operatorname{Pr}>X^{2}\right)\end{array}$ \\
\hline $\begin{array}{l}\text { Capacidade preditiva } \\
\text { (Índice c) }\end{array}$ & 0,596 & & & \\
\hline Razão de verossimilhança & & & 53,735 & 0,0204 \\
\hline $\begin{array}{l}\text { Log-verossimilhança } \\
\text { (modelo nulo) }\end{array}$ & 185,896 & & & \\
\hline $\begin{array}{l}\text { Log-verossimilhança } \\
\text { (modelo estimado) }\end{array}$ & 180,522 & & & \\
\hline $\begin{array}{l}\text { Teste de Hosmer- } \\
\text { Lemeshow }\end{array}$ & & & 12,826 & 0,5266 \\
\hline Número de casos & 135 & & & \\
\hline \multicolumn{5}{|c|}{ Estrato AT/FO - Grandes empresas } \\
\hline Intercepto & 45,158 & 10,551 & 183,175 & $<0,0001$ \\
\hline \multicolumn{5}{|l|}{ Variável explanatória } \\
\hline$X_{E M P R}$ & 0,6072 & 0,2013 & 90,997 & $0,0026^{* *}$ \\
\hline$X_{\text {CONS }}$ & 0,5160 & 0,2414 & 45,696 & $0,0325^{\star}$ \\
\hline $\begin{array}{l}\text { Qualidade de ajuste do } \\
\text { modelo }\end{array}$ & & & Qui quadrado & $\begin{array}{l}\text { Significância } \\
\left(\operatorname{Pr}>X^{2}\right)\end{array}$ \\
\hline $\begin{array}{l}\text { Capacidade preditiva } \\
\text { (Índice c) }\end{array}$ & 0,728 & & & \\
\hline Razão de verossimilhança & & & 147,846 & $0,0006^{\star \star \star}$ \\
\hline $\begin{array}{l}\text { Log-verossimilhança } \\
\text { (Modelo nulo) }\end{array}$ & 119,435 & & & \\
\hline $\begin{array}{l}\text { Log-verossimilhança } \\
\text { (Modelo estimado) }\end{array}$ & 104,650 & & & \\
\hline $\begin{array}{ll}\begin{array}{l}\text { Teste de } \\
\text { Lemeshow }\end{array} & \text { Hosmer- } \\
\end{array}$ & & & 115,740 & 0,0722 \\
\hline Número de casos & 113 & & & \\
\hline
\end{tabular}

A cooperação com empresas de consultoria influenciando positivamente a apropriação de valor das inovações geradas em arranjos cooperativos, expressa 
pelos seus impactos regulatórios, foi confirmada (H5.5) para dois estratos, respectivamente: micro e pequenas empresas (coeficiente de regressão $=0,5976$ ); e grandes empresas (coeficiente de regressão $=0,5160$ ).

Finalmente, a cooperação com outra empresa do grupo influenciando positivamente a apropriação de valor das inovações geradas em arranjos cooperativos (pelos seus impactos regulatórios) foi confirmada pelo coeficiente de regressão positivo $(0,6072)$ para o estrato de grandes empresas deste agrupamento setorial (AT/FO).

Quadro 4.11 - Resultados das hipóteses de pesquisa dos modelos $Y_{R E G U}$ referentes aos estratos AT/FO

\begin{tabular}{|c|c|c|}
\hline Hipótese & Descrição & Resultado \\
\hline H1.5 & $\begin{array}{l}\text { A cooperação com clientes e consumidores influencia } \\
\text { positivamente a apropriação de valor das inovações geradas } \\
\text { em arranjos cooperativos, pelos seus impactos regulatórios. }\end{array}$ & Não confirmada. \\
\hline H2.5 & $\begin{array}{l}\text { A cooperação com fornecedores influencia positivamente a } \\
\text { apropriação de valor das inovações geradas em arranjos } \\
\text { cooperativos, pelos seus impactos regulatórios. }\end{array}$ & $\begin{array}{l}\text { Confirmada para dois } \\
\text { estratos: } \\
\text { AT/FO - Micro e pequenas } \\
\text { empresas } \\
\text { AT/FO - Médias empresas }\end{array}$ \\
\hline H3.5 & $\begin{array}{l}\text { A cooperação com concorrentes influencia positivamente a } \\
\text { apropriação de valor das inovações geradas em arranjos } \\
\text { cooperativos, pelos seus impactos regulatórios. }\end{array}$ & Não confirmada \\
\hline H4.5 & $\begin{array}{l}\text { A cooperação com outra empresa do grupo influencia } \\
\text { positivamente a apropriação de valor das inovações geradas } \\
\text { em arranjos cooperativos, pelos seus impactos regulatórios. }\end{array}$ & $\begin{array}{l}\text { Confirmadas para o extrato } \\
\text { AT/FO - Grandes empresas }\end{array}$ \\
\hline H5.5 & $\begin{array}{l}\text { A cooperação com empresas de consultoria influencia } \\
\text { positivamente a apropriação de valor das inovações geradas } \\
\text { em arranjos cooperativos, pelos seus impactos regulatórios. }\end{array}$ & $\begin{array}{l}\text { Confirmada para dois } \\
\text { estratos: } \\
\text { AT/FO - Micro e pequenas } \\
\text { empresas } \\
\text { AT/FO - Grandes empresas }\end{array}$ \\
\hline H6.5 & $\begin{array}{l}\text { A cooperação com universidades e institutos de pesquisa } \\
\text { influencia positivamente a apropriação de valor das } \\
\text { inovações geradas em arranjos cooperativos, pelos seus } \\
\text { impactos regulatórios. }\end{array}$ & Não confirmada \\
\hline H7.5 & $\begin{array}{l}\text { A cooperação com centros de capacitação profissional e } \\
\text { assistência técnica influencia positivamente a apropriação de } \\
\text { valor das inovações geradas em arranjos cooperativos, pelos } \\
\text { seus impactos regulatórios. }\end{array}$ & Não confirmada \\
\hline H8.5 & $\begin{array}{l}\text { A cooperação com instituições de ensaios e certificações } \\
\text { influencia positivamente a apropriação de valor das } \\
\text { inovações geradas em arranjos cooperativos, pelos seus } \\
\text { impactos regulatórios. }\end{array}$ & Não confirmada \\
\hline
\end{tabular}

Fonte: Elaboração própria.

\subsubsection{6}

\section{Discussão dos resultados do agrupamento setorial AT/FO}

Vários pontos importantes das tabelas 4.13 a 4.17 merecem destaque. As empresas de menor porte do agrupamento setorial AT/FO tendem a cooperar para inovar, visando principalmente atender requisitos normativos e regulatórios de seus setores de atuação, em um primeiro nível de importância. Em um segundo nível, cooperam com clientes e consumidores para criar inovações com impactos 
sociais e de mercado; e com concorrentes, gerando inovações com impactos na produção (excelência operacional e redução de custos).

Já as médias empresas que atuam nos setores deste agrupamento buscam cooperação interorganizacional com diversos objetivos de inovação, desde a manutenção no mercado no qual atuam até o atendimento a requisitos de regulamentos e normas aplicáveis. Nestes casos, os parceiros preferenciais para cooperação em projetos de PD\&I foram empresas do mesmo grupo, gerando inovações com impactos mercadológicos; na produção; e sociais. Outros parceiros foram fornecedores que inovaram em conjunto para atendimento a regulamentos e normas aplicáveis a empresas dos setores em que atuam. Parcerias com instituições de ensaios e certificações foram consideradas importantes e influenciaram positivamente a geração de inovações para atendimento a exigências ambientais legais e a requisitos de normas de gestão ambiental aplicáveis.

As grandes empresas que atuam nos setores AT/FO buscaram cooperação interorganizacional com diversos objetivos de inovação, desde a manutenção nos mercados em que atuam até atendimento a requisitos de regulamentos e normas aplicáveis. Neste caso, os parceiros preferenciais para cooperação em projetos de PD\&I foram empresas os clientes e consumidores, gerando inovações com impactos mercadológicos; ambientais e sociais. Em ambientes de competição acirrada, as grandes empresas de um determinado setor concentram-se nas demandas dos clientes e na experimentação de outras alternativas, intensificandose assim a cooperação com clientes e consumidores como principais parceiros dos arranjos cooperativos para inovação.

Outros parceiros foram empresas do mesmo grupo e firmas de consultoria criando inovações com impactos regulatórios. Finalmente, os centros de capacitação profissional como parceiros cooperaram na geração de inovações para melhoria e/ou mudanças na produção.

\subsection{2.}

Análise da influência dos parceiros em arranjos cooperativos sobre a apropriação de valor das inovações geradas: agrupamento setorial AT/FR

As tabelas 4.18 a 4.22 , a seguir, apresentam as estimativas dos coeficientes de regressão em relação aos modelos logit para empresas do agrupamento setorial 
AT/FR da indústria de transformação no Brasil, que implementaram inovações em arranjos cooperativos com outras organizações no período de 2012 a 2014.

\subsubsection{1}

\section{Modelos estimados $Y_{M E R C}$}

Tabela 4.18 - Resultados das regressões logísticas para os modelos estimados $Y_{M E R C}$ referentes aos estratos AT/FR

\begin{tabular}{|c|c|c|c|c|}
\hline \multicolumn{5}{|c|}{ Modelos estimados $Y_{M E R C}$ referentes aos estratos AT/FR } \\
\hline Parâmetro & $\begin{array}{l}\text { Coeficiente } \\
\text { estimado }(\beta)\end{array}$ & $\begin{array}{l}\text { Erro } \\
\text { padrão }(\varepsilon)\end{array}$ & $\begin{array}{l}\text { Wald } \\
\text { Qui quadrado }\end{array}$ & $\begin{array}{l}\text { Significância } \\
\left(\operatorname{Pr}>X^{2}\right)\end{array}$ \\
\hline \multicolumn{5}{|c|}{ Estrato AT/FR - Micro e pequenas empresas } \\
\hline Intercepto & 14,966 & 0,2856 & 274,529 & $<0,0001^{* * *}$ \\
\hline \multicolumn{5}{|l|}{ Variável explanatória } \\
\hline \multicolumn{5}{|c|}{$\begin{array}{l}\text { Nenhum efeito (adicional) pela entrada das variáveis explanatórias no modelo atendeu ao nível de } \\
\text { significância de } 5 \% \text {. }\end{array}$} \\
\hline $\begin{array}{l}\text { Qualidade de ajuste do } \\
\text { modelo }\end{array}$ & & & Qui quadrado & $\begin{array}{l}\text { Significância } \\
\left(\operatorname{Pr}>X^{2}\right)\end{array}$ \\
\hline $\begin{array}{l}\text { Capacidade preditiva } \\
\text { (Índice c) }\end{array}$ & - & & & \\
\hline Razão de verossimilhança & - & & & - \\
\hline $\begin{array}{l}\text { Log-verossimilhança } \\
\text { (modelo nulo) }\end{array}$ & 78,032 & & & \\
\hline $\begin{array}{l}\text { Log-verossimilhança } \\
\text { (modelo estimado) }\end{array}$ & - & & & \\
\hline $\begin{array}{l}\text { Teste de Hosmer- } \\
\text { Lemeshow }\end{array}$ & - & & & - \\
\hline Número de casos & 82 & & & \\
\hline \multicolumn{5}{|c|}{ Estrato AT/FR - Médias empresas } \\
\hline Parâmetro & $\begin{array}{l}\text { Coeficiente } \\
\text { estimado }(\beta)\end{array}$ & $\begin{array}{l}\text { Erro } \\
\text { padrão }(\varepsilon)\end{array}$ & $\begin{array}{l}\text { Wald } \\
\text { Qui quadrado }\end{array}$ & $\begin{array}{l}\text { Significância } \\
\left(\operatorname{Pr}>X^{2}\right)\end{array}$ \\
\hline Intercepto & 41,209 & 0,7698 & 286,596 & $<0,0001^{* \star *}$ \\
\hline \multicolumn{5}{|l|}{ Variável explanatória } \\
\hline$X_{C E R T}$ & 0,8390 & 0,2231 & 141,400 & $0,0002^{* \star *}$ \\
\hline $\begin{array}{l}\text { Qualidade de ajuste do } \\
\text { modelo }\end{array}$ & & & Qui quadrado & $\begin{array}{l}\text { Significância } \\
\left(\operatorname{Pr}>X^{2}\right)\end{array}$ \\
\hline $\begin{array}{l}\text { Capacidade preditiva } \\
\text { (Índice c) }\end{array}$ & 0,747 & & & \\
\hline Razão de verossimilhança & & & 186,685 & $<0,0001^{* * *}$ \\
\hline $\begin{array}{l}\text { Log-verossimilhança } \\
\text { (modelo nulo) }\end{array}$ & 143,757 & & & \\
\hline $\begin{array}{l}\text { Log-verossimilhança } \\
\text { (modelo estimado) }\end{array}$ & 125,089 & & & \\
\hline $\begin{array}{l}\text { Teste de Hosmer- } \\
\text { Lemeshow }\end{array}$ & & & 13,846 & 0,5004 \\
\hline Número de casos & 165 & & & \\
\hline \multicolumn{5}{|c|}{ Estrato AT/FR - Grandes empresas } \\
\hline Parâmetro & $\begin{array}{l}\text { Coeficiente } \\
\text { estimado } \\
(\beta)\end{array}$ & $\begin{array}{l}\text { Erro padrão } \\
(\varepsilon)\end{array}$ & $\begin{array}{l}\text { Wald } \\
\text { Qui quadrado }\end{array}$ & $\begin{array}{l}\text { Significância } \\
\left(\operatorname{Pr}>X^{2}\right)\end{array}$ \\
\hline Intercepto & 19,124 & 0,2971 & 414,244 & $<0,0001^{* \star *}$ \\
\hline \multicolumn{5}{|c|}{ Variável explanatória } \\
\hline \multicolumn{5}{|c|}{$\begin{array}{l}\text { Nenhum efeito (adicional) pela entrada das variáveis explanatórias no modelo atendeu ao nível de } \\
\text { significância de } 5 \% \text {. }\end{array}$} \\
\hline $\begin{array}{l}\text { Qualidade de ajuste do } \\
\text { modelo }\end{array}$ & & & Qui quadrado & $\begin{array}{l}\text { Significância } \\
\left(\operatorname{Pr}>X^{2}\right)\end{array}$ \\
\hline $\begin{array}{l}\text { Capacidade preditiva } \\
\text { (Índice c) }\end{array}$ & - & & & \\
\hline Razão de verossimilhança & - & & & - \\
\hline $\begin{array}{l}\text { Log-verossimilhança } \\
\text { (modelo nulo) }\end{array}$ & 77,554 & & & \\
\hline $\begin{array}{l}\text { Log-verossimilhança } \\
\text { (modelo estimado) }\end{array}$ & - & & & \\
\hline $\begin{array}{l}\text { Teste de Hosmer- } \\
\text { Lemeshow }\end{array}$ & - & & & - \\
\hline Número de casos & 101 & & & \\
\hline
\end{tabular}


Para dois extratos - 'AT/FR - Micro e pequenas empresas' e 'AT/FR Grandes empresas', não foi possível estimar os modelos de regressão $Y_{M E R C}$ pelos resultados iniciais da aplicação do procedimento Stepwise, que indicaram que nenhum efeito (adicional) pela entrada das variáveis explanatórias nos dois modelos atenderia ao nível de significância de 5\%.

A avaliação da qualidade de ajuste do modelo $Y_{M E R C}$ para o estrato 'AT/FR - Médias empresas' indicou que a capacidade preditiva deste modelo, medida pelo Índice c, atingiu o valor de 0,747. Além disso, a estatística da log-verosimilhança (valor=125,089) corroborou a significância global do modelo, em comparação ao valor superior observado no modelo nulo (valor $=143,757$ ). Como nos modelos apresentados anteriormente, todas as estimativas dos parâmetros da regressão deste modelo foram estatisticamente significativas ao nível de 5\%.

$\mathrm{Na}$ sequência, procedeu-se a análise dos resultados apresentados na tabela 4.18 com o objetivo de testar as hipóteses de pesquisa relativas aos modelos estimados $Y_{M E R C}$ para estratos referentes aos estratos AT/FR (quadro 4.12).

Quadro 4.12 - Resultados das hipóteses de pesquisa dos modelos $Y_{M E R C}$ referentes aos estratos AT/FR

\begin{tabular}{|c|c|c|}
\hline Hipótese & Descrição & Resultado \\
\hline H1.1 & $\begin{array}{l}\text { A cooperação com clientes e consumidores influencia } \\
\text { positivamente a apropriação de valor das inovações geradas } \\
\text { em arranjos cooperativos, pelos seus impactos } \\
\text { mercadológicos. }\end{array}$ & Não confirmada \\
\hline H2.1 & $\begin{array}{l}\text { A cooperação com fornecedores influencia positivamente a } \\
\text { apropriação de valor das inovações geradas em arranjos } \\
\text { cooperativos, pelos seus impactos mercadológicos. }\end{array}$ & Não confirmada \\
\hline H3.1 & $\begin{array}{l}\text { A cooperação com concorrentes influencia positivamente a } \\
\text { apropriação de valor das inovações geradas em arranjos } \\
\text { cooperativos, pelos seus impactos mercadológicos. }\end{array}$ & Não confirmada \\
\hline H4.1 & $\begin{array}{l}\text { A cooperação com outra empresa do grupo influencia } \\
\text { positivamente a apropriação de valor das inovações geradas } \\
\text { em arranjos cooperativos, pelos seus impactos } \\
\text { mercadológicos. }\end{array}$ & Não confirmada \\
\hline H5.1 & $\begin{array}{l}\text { A cooperação com empresas de consultoria influencia } \\
\text { positivamente a apropriação de valor das inovações geradas } \\
\text { em arranjos cooperativos, pelos seus impactos } \\
\text { mercadológicos. }\end{array}$ & Não confirmada \\
\hline H6.1 & $\begin{array}{l}\text { A cooperação com universidades e institutos de pesquisa } \\
\text { influencia positivamente a apropriação de valor das inovações } \\
\text { geradas em arranjos cooperativos, pelos seus impactos } \\
\text { mercadológicos. }\end{array}$ & Não confirmada \\
\hline H7.1 & $\begin{array}{l}\text { A cooperação com centros de capacitação profissional e } \\
\text { assistência técnica influencia positivamente a apropriação de } \\
\text { valor das inovações geradas em arranjos cooperativos, pelos } \\
\text { seus impactos mercadológicos. }\end{array}$ & Não confirmada \\
\hline H8.1 & $\begin{array}{l}\text { A cooperação com instituições de ensaios e certificações } \\
\text { influencia positivamente a apropriação de valor das inovações } \\
\text { geradas em arranjos cooperativos, pelos seus impactos } \\
\text { mercadológicos. }\end{array}$ & $\begin{array}{l}\text { Confirmada para o estrato } \\
\text { AT/FR - Médias empresas }\end{array}$ \\
\hline
\end{tabular}

Fonte: Elaboração própria. 
Como pode ser observado na tabela 4.18, o modelo estimado $Y_{M E R C}$ referente ao estrato 'AT/FO - Médias empresas' permitiu confirmar que o coeficiente estimado $(0,8390)$ para a variável explanatória $X_{C E R T}$ foi estatisticamente significativo para um nível de significância de 5\%, confirmando-se a hipótese H8.1.

\subsubsection{2}

\section{Modelos estimados YPROD}

A tabela 4.19 reúne os resultados das regressões logísticas para os modelos estimados $Y_{P R O D}$ referentes aos estratos do agrupamento setorial AT/FR.

Tabela 4.19 - Resultados das regressões logísticas para os modelos estimados $Y_{P R O D}$ referentes aos estratos AT/FR

\begin{tabular}{|c|c|c|c|c|}
\hline \multicolumn{5}{|c|}{ Modelos estimados $Y_{P R O D}$ referentes aos estratos AT/FR } \\
\hline Parâmetro & $\begin{array}{l}\text { Coeficiente } \\
\text { estimado }(\beta)\end{array}$ & $\begin{array}{l}\text { Erro } \\
\text { padrão }(\varepsilon)\end{array}$ & $\begin{array}{l}\text { Wald } \\
\text { Qui quadrado }\end{array}$ & $\begin{array}{l}\text { Significância } \\
\left(\mathrm{Pr}>\mathrm{X}^{2}\right)\end{array}$ \\
\hline \multicolumn{5}{|c|}{ Estrato AT/FR - Micro e pequenas empresas } \\
\hline Intercepto & 19,582 & 0,8723 & 50,392 & $0,0248^{*}$ \\
\hline \multicolumn{5}{|l|}{ Variável explanatória } \\
\hline$X_{\text {CONS }}$ & 0,5057 & 0,2429 & 43,343 & $0,0374^{*}$ \\
\hline $\begin{array}{l}\text { Qualidade de ajuste do } \\
\text { modelo }\end{array}$ & & & Qui quadrado & $\begin{array}{l}\text { Significância } \\
\left(\mathrm{Pr}>\mathrm{X}^{2}\right)\end{array}$ \\
\hline $\begin{array}{l}\text { Capacidade preditiva } \\
\text { (Índice c) }\end{array}$ & 0,609 & & & \\
\hline Razão de verossimilhança & & & 49,021 & $0,0268^{*}$ \\
\hline $\begin{array}{l}\text { Log-verossimilhança } \\
\text { (modelo nulo) }\end{array}$ & 112,454 & & & \\
\hline $\begin{array}{l}\text { Log-verossimilhança } \\
\text { (modelo estimado) }\end{array}$ & 107,551 & & & \\
\hline $\begin{array}{l}\text { Teste de Hosmer- } \\
\text { Lemeshow }\end{array}$ & & & 0,4413 & 0,8020 \\
\hline Número de casos & 82 & & & \\
\hline \multicolumn{5}{|c|}{ Estrato AT/FR - Médias empresas } \\
\hline Intercepto & 24,689 & 0,6455 & 146,294 & $0,0001^{* * *}$ \\
\hline \multicolumn{5}{|l|}{ Variável explanatória } \\
\hline$X_{C C A P}$ & 0,5672 & 0,1809 & 98,268 & $0,0017^{* *}$ \\
\hline $\begin{array}{l}\text { Qualidade de ajuste do } \\
\text { modelo }\end{array}$ & & & Qui quadrado & $\begin{array}{l}\text { Significância } \\
\left(\operatorname{Pr}>X^{2}\right)\end{array}$ \\
\hline $\begin{array}{l}\text { Capacidade preditiva } \\
\text { (Índice c) }\end{array}$ & 0,637 & & & \\
\hline Razão de verossimilhança & & & 116,058 & $0,0007^{* * *}$ \\
\hline $\begin{array}{l}\text { Log-verossimilhança } \\
\text { (modelo nulo) }\end{array}$ & 215,164 & & & \\
\hline $\begin{array}{l}\text { Log-verossimilhança } \\
\text { (modelo estimado) }\end{array}$ & 203,558 & & & \\
\hline $\begin{array}{l}\text { Teste de Hosmer- } \\
\text { Lemeshow }\end{array}$ & & & 0,9484 & 0,6224 \\
\hline Número de casos & 165 & & & \\
\hline
\end{tabular}


Tabela 4.19 - Resultados das regressões logísticas para os modelos estimados $Y_{P R O D}$ referentes aos estratos AT/FR (cont.)

\begin{tabular}{|c|c|c|c|c|}
\hline \multicolumn{5}{|c|}{ Modelos estimados $Y_{P R O D}$ referentes aos estratos AT/FR } \\
\hline Parâmetro & $\begin{array}{l}\text { Coeficiente } \\
\text { estimado }(\beta)\end{array}$ & $\begin{array}{l}\text { Erro } \\
\text { padrão }(\varepsilon)\end{array}$ & $\begin{array}{l}\text { Wald } \\
\text { Qui quadrado }\end{array}$ & $\begin{array}{l}\text { Significância } \\
\left(\mathrm{Pr}>X^{2}\right)\end{array}$ \\
\hline \multicolumn{5}{|c|}{ Estrato AT/FR - Grandes empresas } \\
\hline Intercepto & 0,5801 & 0,6986 & 0,6896 & $0,0463^{*}$ \\
\hline \multicolumn{5}{|l|}{ Variável explanatória } \\
\hline$X_{F O R N}$ & 0,6373 & 0,2070 & 94,834 & $0,0021^{* *}$ \\
\hline$X_{\text {CONS }}$ & 0,4509 & 0,2247 & 40,257 & $0,0448^{*}$ \\
\hline $\begin{array}{l}\text { Qualidade de ajuste do } \\
\text { modelo }\end{array}$ & & & Qui quadrado & $\begin{array}{l}\text { Significância } \\
\left(\operatorname{Pr}>X^{2}\right)\end{array}$ \\
\hline $\begin{array}{l}\text { Capacidade preditiva } \\
\text { (Índice c) }\end{array}$ & 0,697 & & & \\
\hline Razão de verossimilhança & & & 119,535 & $0,0025^{* *}$ \\
\hline $\begin{array}{l}\text { Log-verossimilhança } \\
\text { (modelo nulo) }\end{array}$ & 130,346 & & & \\
\hline $\begin{array}{l}\text { Log-verossimilhança } \\
\text { (modelo estimado) }\end{array}$ & 118,392 & & & \\
\hline $\begin{array}{l}\text { Teste de Hosmer- } \\
\text { Lemeshow }\end{array}$ & & & 22,564 & 0,9443 \\
\hline Número de casos & 101 & & & \\
\hline
\end{tabular}

As capacidades preditivas dos modelos apresentados na tabela 4.19 (medidas pelo Índice c) atingiram valores entre 0,697 e 0,609. Além disso, as estatísticas da log-verosimilhança corroboraram a significância global dos modelos em foco, em comparação a valores superiores calculados para os respectivos modelos nulos.

Cabe ressaltar ainda que todas estimativas dos parâmetros da regressão deste modelo foram estatisticamente significativas ao nível de 5\% (testes de Wald e da razão de verossimilhança).

Analisaram-se os resultados apresentados na tabela 4.19, visando testar as hipóteses de pesquisa relativas aos modelos estimados $Y_{P R O D}$ para estratos referentes aos estratos AT/FR (ver quadro 4.13, a seguir).

Quadro 4.13 - Resultados das hipóteses de pesquisa dos modelos $Y_{P R O D}$ referentes aos estratos AT/FR

\begin{tabular}{|l|l|l|}
\hline Hipótese & Descrição & Resultado \\
\hline H1.2 & $\begin{array}{l}\text { A cooperação com clientes e consumidores influencia } \\
\text { positivamente a apropriação de valor das inovações geradas } \\
\text { em arranjos cooperativos, pelos seus impactos na produção. }\end{array}$ & Não confirmada. \\
\hline H2.2 & $\begin{array}{l}\text { A cooperação com fornecedores influencia positivamente a } \\
\text { apropriação de valor das inovações geradas em arranjos } \\
\text { cooperativos, pelos seus impactos na produção. }\end{array}$ & $\begin{array}{l}\text { Confirmada para o estrato } \\
\text { AT/FR - Grandes } \\
\text { empresas }\end{array}$ \\
\hline H3.2 & $\begin{array}{l}\text { A cooperação com concorrentes influencia positivamente a } \\
\text { apropriação de valor das inovações geradas em arranjos } \\
\text { cooperativos, pelos seus impactos na produção. }\end{array}$ & Não confirmada. \\
\hline H4.2 & $\begin{array}{l}\text { A cooperação com outra empresa do grupo influencia } \\
\text { positivamente a apropriação de valor das inovações geradas } \\
\text { em arranjos cooperativos, pelos seus impactos na produção. }\end{array}$ & Não confirmada. \\
\hline
\end{tabular}




\begin{tabular}{|l|l|l|}
\hline H5.2 & $\begin{array}{l}\text { A cooperação com empresas de consultoria influencia } \\
\text { positivamente a apropriação de valor das inovações geradas } \\
\text { em arranjos cooperativos, pelos seus impactos na produção. }\end{array}$ & $\begin{array}{l}\text { Confirmada para } \\
\text { estratos AT/FR }- \text { Micro es } \\
\text { pequenas empresas } \\
\text { AT/FR } \\
\text { empresas }\end{array}$ \\
\hline H6.2 & $\begin{array}{l}\text { A cooperação com universidades e institutos de pesquisa } \\
\text { influencia positivamente a apropriação de valor das inovações } \\
\text { geradas em arranjos cooperativos, pelos seus impactos na } \\
\text { produção. }\end{array}$ & Não confirmada. \\
\hline H7.2 & $\begin{array}{l}\text { A cooperação com centros de capacitação profissional e } \\
\text { assistência técnica influencia positivamente a apropriação de } \\
\text { valor das inovações geradas em arranjos cooperativos, pelos } \\
\text { seus impactos na produção. }\end{array}$ & $\begin{array}{l}\text { AT/FR - Médias empresas } \\
\text { H8.2 }\end{array}$ \\
\hline & $\begin{array}{l}\text { A cooperação com instituições de ensaios e certificações } \\
\text { influencia positivamente a apropriação de valor das inovações } \\
\text { geradas em arranjos cooperativos, pelos seus impactos na } \\
\text { produção. }\end{array}$ & Não confirmada. \\
\hline
\end{tabular}

Fonte: Elaboração própria.

Como evidenciam os resultados apresentados na tabela 4.19, o modelo estimado $Y_{P R O D}$ referente ao estrato 'AT/FR- Micro e pequenas empresas' permitiu confirmar que o coeficiente estimado $(0,5057)$ para a variável explanatória $X_{C O N S}$ foi estatisticamente significativo para um nível de significância de 5\%. Assim, rejeitou-se a hipótese nula de que não existia relação entre a referida variável explanatória e a variável dependente, confirmando-se a hipótese H5.2 para este estrato. Esta hipótese também foi confirmada para o estrato 'AT/FR - Grandes empresas', pelo valor do coeficiente de regressão no valor de 0,4509 (sinal positivo).

A cooperação com fornecedores influenciando positivamente a apropriação de valor das inovações geradas em arranjos cooperativos (expressa pelos seus impactos na produção) foi confirmada com o sinal do coeficiente de regressão positivo $(0,6373)$ para as empresas de grande porte (hipótese H2.2).

Finalmente, o modelo estimado $Y_{P R O D}$ referente ao estrato 'AT/FR-Médias empresas' permitiu confirmar que o coeficiente estimado $(0,5672)$ para a variável explanatória $X_{C C A P}$ foi estatisticamente significativo para um nível de significância de 5\%. Assim, rejeitou-se a hipótese nula e confirmou-se hipótese H7.2 para este estrato da amostra.

\subsubsection{3}

\section{Modelos estimados $Y_{A M B I}$}

A tabela 4.20 reúne os resultados das regressões logísticas para os modelos estimados $Y_{A M B I}$ referentes aos estratos do agrupamento setorial AT/FR. 
Tabela 4.20 - Resultados das regressões logísticas para os modelos estimados $Y_{A M B I}$ referentes aos estratos AT/FR

\begin{tabular}{|c|c|c|c|c|}
\hline \multicolumn{5}{|c|}{ Modelos estimados $Y_{A M B \mid}$ referentes aos estratos AT/FR } \\
\hline Parâmetro & $\begin{array}{l}\text { Coeficiente } \\
\text { estimado }(\beta)\end{array}$ & $\begin{array}{l}\text { Erro } \\
\text { padrão }(\varepsilon)\end{array}$ & $\begin{array}{l}\text { Wald } \\
\text { Qui quadrado }\end{array}$ & $\begin{array}{l}\text { Significância } \\
\left(\operatorname{Pr}>X^{2}\right)\end{array}$ \\
\hline \multicolumn{5}{|c|}{ Estrato AT/FR - Micro e pequenas empresas } \\
\hline Parâmetro & $\begin{array}{l}\text { Coeficiente } \\
\text { estimado }(\beta)\end{array}$ & $\begin{array}{l}\text { Erro } \\
\text { padrão }(\varepsilon)\end{array}$ & $\begin{array}{l}\text { Wald } \\
\text { Qui quadrado }\end{array}$ & $\begin{array}{l}\text { Significância } \\
\left(\operatorname{Pr}>X^{2}\right)\end{array}$ \\
\hline Intercepto & 0,6516 & 0,9329 & 0,4879 & 0,4849 \\
\hline \multicolumn{5}{|l|}{ Variável explanatória } \\
\hline$X_{C C A P}$ & 0,6548 & 0,2834 & 53,374 & $0,0209^{*}$ \\
\hline $\begin{array}{l}\text { Qualidade de ajuste do } \\
\text { modelo }\end{array}$ & & & Qui quadrado & $\begin{array}{l}\text { Significância } \\
\left(\operatorname{Pr}>X^{2}\right)\end{array}$ \\
\hline $\begin{array}{l}\text { Capacidade preditiva } \\
\text { (Índice c) }\end{array}$ & 0,679 & & & \\
\hline Razão de verossimilhança & & & 52,509 & $0,0219^{*}$ \\
\hline $\begin{array}{l}\text { Log-verossimilhança } \\
\text { (modelo nulo) }\end{array}$ & 78,032 & & & \\
\hline $\begin{array}{l}\text { Log-verossimilhança } \\
\text { (modelo estimado) }\end{array}$ & 72,781 & & & \\
\hline $\begin{array}{l}\text { Teste de Hosmer- } \\
\text { Lemeshow }\end{array}$ & & & 53,374 & 0,0707 \\
\hline Número de casos & 82 & & & \\
\hline \multicolumn{5}{|c|}{ Estrato AT/FR - Médias empresas } \\
\hline Intercepto & 0,4210 & 0,4929 & 0,7293 & 0,3931 \\
\hline \multicolumn{5}{|l|}{ Variável explanatória } \\
\hline$X_{C C A P}$ & 0,3633 & 0,1499 & 58,714 & $0,0154^{*}$ \\
\hline $\begin{array}{l}\text { Qualidade de ajuste do } \\
\text { modelo }\end{array}$ & & & Qui quadrado & $\begin{array}{l}\text { Significância } \\
\left(\mathrm{Pr}>\mathrm{X}^{2}\right)\end{array}$ \\
\hline $\begin{array}{l}\text { Capacidade preditiva } \\
\text { (Índice c) }\end{array}$ & 0,614 & & & \\
\hline Razão de verossimilhança & & & 58,937 & $0,0152^{*}$ \\
\hline $\begin{array}{l}\text { Log-verossimilhança } \\
\text { (modelo nulo) }\end{array}$ & 208,636 & & & \\
\hline $\begin{array}{l}\text { Log-verossimilhança } \\
\text { (modelo estimado) }\end{array}$ & 202,742 & & & \\
\hline $\begin{array}{l}\text { Teste de Hosmer- } \\
\text { Lemeshow }\end{array}$ & & & 23,405 & 0,3103 \\
\hline Número de casos & 165 & & & \\
\hline \multicolumn{5}{|c|}{ Estrato AT/FR - Grandes empresas } \\
\hline Intercepto & 0,3624 & 0,4213 & 0,7398 & 0,3897 \\
\hline \multicolumn{5}{|l|}{ Variável explanatória } \\
\hline$X_{F O R N}$ & 0,4015 & 0,1951 & 42,349 & $0,0396^{*}$ \\
\hline $\begin{array}{l}\text { Qualidade de ajuste do } \\
\text { modelo }\end{array}$ & & & Qui quadrado & $\begin{array}{l}\text { Significância } \\
\left(\mathrm{Pr}>\mathrm{X}^{2}\right)\end{array}$ \\
\hline $\begin{array}{l}\text { Capacidade preditiva } \\
\text { (Índice c) }\end{array}$ & 0,614 & & & \\
\hline Razão de verossimilhança & & & 45,905 & $0,0322^{*}$ \\
\hline $\begin{array}{l}\text { Log-verossimilhança } \\
\text { (modelo nulo) }\end{array}$ & 135,617 & & & \\
\hline $\begin{array}{l}\text { Log-verossimilhança } \\
\text { (modelo estimado) }\end{array}$ & 131,027 & & & \\
\hline $\begin{array}{l}\text { Teste de Hosmer- } \\
\text { Lemeshow }\end{array}$ & & & 0,9721 & 0,6150 \\
\hline Número de casos & 101 & & & \\
\hline
\end{tabular}

A avaliação da qualidade de ajuste dos modelos $Y_{A M B I}$ referentes aos três estratos do agrupamento setorial AT/FR indicou que as capacidades preditivas destes modelos, medidas pelo Índice c, atingiram valores em média da ordem de 0,650 . 
Além disso, as estatísticas da log-verosimilhança confirmaram a significância global dos modelos, quando se compram os valores dos modelos estimados aos valores superiores observados nos respectivos modelos nulos.

Como nos modelos apresentados anteriormente, todas as estimativas dos parâmetros da regressão deste modelo foram estatisticamente significativas ao nível de 5\%.

$\mathrm{Na}$ sequência, realizou-se a análise dos resultados apresentados na tabela 4.20 para testar as hipóteses de pesquisa relativas aos modelos estimados $Y_{A M B I}$ para os três estratos do agrupamento setorial AT/FR (quadro 4.14).

Quadro 4.14 - Resultados das hipóteses de pesquisa dos modelos $Y_{A M B I}$ referentes aos estratos AT/FR

\begin{tabular}{|c|c|c|}
\hline Hipótese & Descrição & Resultado \\
\hline H1.3 & $\begin{array}{l}\text { A cooperação com clientes e consumidores influencia } \\
\text { positivamente a apropriação de valor das inovações geradas } \\
\text { em arranjos cooperativos, pelos seus impactos ambientais. }\end{array}$ & Não confirmada. \\
\hline H2.3 & $\begin{array}{l}\text { A cooperação com fornecedores influencia positivamente a } \\
\text { apropriação de valor das inovações geradas em arranjos } \\
\text { cooperativos, pelos seus impactos ambientais. }\end{array}$ & $\begin{array}{l}\text { Confirmada para os } \\
\text { estratos AT/FR - Grandes } \\
\text { empresas }\end{array}$ \\
\hline H3.3 & $\begin{array}{l}\text { A cooperação com concorrentes influencia positivamente a } \\
\text { apropriação de valor das inovações geradas em arranjos } \\
\text { cooperativos, pelos seus impactos ambientais. }\end{array}$ & Não confirmada. \\
\hline H4.3 & $\begin{array}{l}\text { A cooperação com outra empresa do grupo influencia } \\
\text { positivamente a apropriação de valor das inovações geradas } \\
\text { em arranjos cooperativos, pelos seus impactos ambientais. }\end{array}$ & Não confirmada. \\
\hline H5.3 & $\begin{array}{l}\text { A cooperação com empresas de consultoria influencia } \\
\text { positivamente a apropriação de valor das inovações geradas } \\
\text { em arranjos cooperativos, pelos seus impactos ambientais. }\end{array}$ & Não confirmada. \\
\hline H6.3 & $\begin{array}{l}\text { A cooperação com universidades e institutos de pesquisa } \\
\text { influencia positivamente a apropriação de valor das inovações } \\
\text { geradas em arranjos cooperativos, pelos seus impactos } \\
\text { ambientais. }\end{array}$ & Não confirmada. \\
\hline H7.3 & $\begin{array}{l}\text { A cooperação com centros de capacitação profissional e } \\
\text { assistência técnica influencia positivamente a apropriação de } \\
\text { valor das inovações geradas em arranjos cooperativos, pelos } \\
\text { seus impactos ambientais }\end{array}$ & $\begin{array}{l}\text { Confirmada para os } \\
\text { estratos AT/FR - Micro e } \\
\text { pequenas empresas } \\
\text { AT/FR - Médias empresas }\end{array}$ \\
\hline H8.3 & $\begin{array}{l}\text { A cooperação com instituições de ensaios e certificações } \\
\text { influencia positivamente a apropriação de valor das inovações } \\
\text { geradas em arranjos cooperativos, pelos seus impactos } \\
\text { ambientais. }\end{array}$ & Não confirmada. \\
\hline
\end{tabular}

O modelo estimado $Y_{A M B I}$ referente ao estrato 'AT/FR - Grandes empresas' permitiu confirmar que o coeficiente estimado $(0,4015)$ para a variável explanatória $X_{F O R N}$ foi estatisticamente significativo para um nível de significância de 5\%. Confirmou-se assim a hipótese $\mathrm{H} 2.3$ para este estrato da amostra.

Já a hipótese H7.3 de que a cooperação com centros de capacitação profissional e assistência técnica influencia positivamente a apropriação de valor das inovações geradas em arranjos cooperativos foi confirmada para dois estratos 
da amostra, segundo os valores positivos dos coeficientes de regressão $(0,6548$ par ao estrato das micro e pequenas empresas e 0,3633 para as médias empresas).

Já a hipótese H7.3 de que a cooperação com centros de capacitação profissional e assistência técnica influencia positivamente a apropriação de valor das inovações geradas em arranjos cooperativos foi confirmada para dois estratos da amostra, segundo os valores positivos dos coeficientes estimados (igual a 0,6548 para o estrato das micro e pequenas empresas e a 0,3633 para as médias empresas).

\subsubsection{4}

\section{Modelos estimados $Y_{\text {socl }}$}

A tabela 4.21, a seguir, reúne os resultados das regressões logísticas para os modelos estimados $Y_{\text {Socl }}$ referentes aos estratos AT/FR.

Tabela 4.21 - Resultados das regressões logísticas para os modelos estimados $Y_{s o c}$ referentes aos estratos AT/FR

\begin{tabular}{|c|c|c|c|c|}
\hline \multicolumn{5}{|c|}{ Modelos estimados $Y_{\text {socl }}$ referentes aos estratos AT/FR } \\
\hline Parâmetro & $\begin{array}{l}\text { Coeficiente } \\
\text { estimado }(\beta)\end{array}$ & $\begin{array}{l}\text { Erro } \\
\text { padrão }(\varepsilon)\end{array}$ & $\begin{array}{l}\text { Wald } \\
\text { Qui quadrado }\end{array}$ & $\begin{array}{l}\text { Significância } \\
\left(\operatorname{Pr}>X^{2}\right)\end{array}$ \\
\hline \multicolumn{5}{|c|}{ Estrato AT/FR - Micro e pequenas empresas } \\
\hline Intercepto & 0,0976 & 0,2211 & 0,1950 & 0,6588 \\
\hline \multicolumn{5}{|l|}{ Variável explanatória } \\
\hline \multicolumn{5}{|c|}{$\begin{array}{l}\text { Nenhum efeito (adicional) pela entrada das variáveis explanatórias no modelo atendeu ao nível de } \\
\text { significância de } 5 \% \text {. }\end{array}$} \\
\hline $\begin{array}{l}\text { Qualidade de ajuste do } \\
\text { modelo }\end{array}$ & & & Qui quadrado & $\begin{array}{l}\text { Significância } \\
\left(\operatorname{Pr}>X^{2}\right)\end{array}$ \\
\hline $\begin{array}{l}\text { Capacidade preditiva } \\
\text { (Índice c) }\end{array}$ & - & & & \\
\hline Razão de verossimilhança & - & & & - \\
\hline $\begin{array}{l}\text { Log-verossimilhança } \\
\text { (modelo nulo) }\end{array}$ & 113,481 & & & \\
\hline $\begin{array}{l}\text { Log-verossimilhança } \\
\text { (modelo estimado) }\end{array}$ & - & & & \\
\hline $\begin{array}{l}\text { Teste de Hosmer- } \\
\text { Lemeshow }\end{array}$ & & & - & - \\
\hline Número de casos & 82 & & & \\
\hline \multicolumn{5}{|c|}{ Estrato AT/FR - Médias empresas } \\
\hline Intercepto & 14,831 & 0,6079 & 59,515 & $0,0147^{*}$ \\
\hline \multicolumn{5}{|l|}{ Variável explanatória } \\
\hline$X_{I C T S}$ & 0,3797 & 0,1634 & 54,018 & $0,0201^{*}$ \\
\hline$X_{C C A P}$ & 0,6535 & 0,1946 & 112,796 & $0,0008^{* * *}$ \\
\hline $\begin{array}{l}\text { Qualidade de ajuste do } \\
\text { modelo }\end{array}$ & & & Qui quadrado & $\begin{array}{l}\text { Significância } \\
\left(\operatorname{Pr}>X^{2}\right)\end{array}$ \\
\hline $\begin{array}{l}\text { Capacidade preditiva } \\
\text { (Índice c) }\end{array}$ & 0,665 & & & \\
\hline Razão de verossimilhança & & & 137,970 & $0,0010^{* *}$ \\
\hline $\begin{array}{l}\text { Log-verossimilhança } \\
\text { (modelo nulo) }\end{array}$ & 220,371 & & & \\
\hline $\begin{array}{l}\text { Log-verossimilhança } \\
\text { (modelo estimado) }\end{array}$ & 212,294 & & & \\
\hline $\begin{array}{l}\text { Teste de Hosmer- } \\
\text { Lemeshow }\end{array}$ & & & 13,203 & 0,8579 \\
\hline Número de casos & 165 & & & \\
\hline
\end{tabular}


Tabela 4.21 - Resultados das regressões logísticas para os modelos estimados $Y_{s o C l}$ referentes aos estratos AT/FR (cont.)

\begin{tabular}{|c|c|c|c|c|}
\hline \multicolumn{5}{|c|}{ Modelos estimados $Y_{\text {socl }}$ referentes aos estratos AT/FR } \\
\hline Parâmetro & $\begin{array}{l}\text { Coeficiente } \\
\text { estimado }(\beta)\end{array}$ & $\begin{array}{l}\text { Erro } \\
\text { padrão }(\varepsilon)\end{array}$ & $\begin{array}{l}\text { Wald } \\
\text { Qui quadrado }\end{array}$ & $\begin{array}{l}\text { Significância } \\
\left(\mathrm{Pr}>\mathrm{X}^{2}\right)\end{array}$ \\
\hline \multicolumn{5}{|c|}{ Estrato AT/FR - Grandes empresas } \\
\hline Intercepto & 23,309 & 0,6234 & 139,789 & $0,0002^{* * *}$ \\
\hline \multicolumn{5}{|l|}{ Variável explanatória } \\
\hline$X_{C E R T}$ & 0,5792 & 0,1938 & 89,367 & $0,0028^{* *}$ \\
\hline $\begin{array}{l}\text { Qualidade de ajuste do } \\
\text { modelo }\end{array}$ & & & Qui quadrado & $\begin{array}{l}\text { Significância } \\
\left(\operatorname{Pr}>X^{2}\right)\end{array}$ \\
\hline $\begin{array}{l}\text { Capacidade preditiva } \\
\text { (Índice c) }\end{array}$ & 0,677 & & & \\
\hline Razão de verossimilhança & & & 100,508 & $0,0015^{\star *}$ \\
\hline $\begin{array}{l}\text { Log-verossimilhança } \\
\text { (modelo nulo) }\end{array}$ & 129,033 & & & \\
\hline $\begin{array}{l}\text { Log-verossimilhança } \\
\text { (modelo estimado) }\end{array}$ & 118,982 & & & \\
\hline $\begin{array}{l}\text { Teste de Hosmer- } \\
\text { Lemeshow }\end{array}$ & & & 0,6098 & 0,7372 \\
\hline Número de casos & 101 & & & \\
\hline
\end{tabular}

Para o extrato 'AT/FR - Micro e pequenas empresas', não foi possível estimar o modelo de regressão $Y_{S O C I}$ pelos resultados iniciais da aplicação do procedimento Stepwise, que indicaram que nenhum efeito (adicional) pela entrada das variáveis explanatórias no referido modelo atenderia ao nível de significância de $5 \%$.

A avaliação da qualidade de ajuste dos modelos $Y_{S O C I}$ referentes aos outros dois estratos do agrupamento setorial AT/FR indicou que as capacidades preditivas destes modelos, medidas pelo Índice c, atingiram valores muito próximos em torno de 0,670 .

Verificou-se também que as estatísticas da log-verosimilhança confirmaram a significância global dos modelos, quando se compram os valores dos modelos estimados aos valores superiores observados nos respectivos modelos nulos.

Como nos modelos apresentados anteriormente, todas as estimativas dos parâmetros da regressão deste modelo foram estatisticamente significativas ao nível de 5\%.

Os resultados apresentados na tabela 4.21 foram analisados para testar as hipóteses de pesquisa relativas aos modelos estimados $Y_{S O C I}$ para dois dos estratos do agrupamento setorial AT/FR (quadro 4.15). 
Quadro 4.15 - Resultados das hipóteses de pesquisa dos modelos $Y_{\text {SOCI }}$ referentes aos estratos AT/FR

\begin{tabular}{|c|c|c|}
\hline Hipótese & Descrição & Resultado \\
\hline H1.4 & $\begin{array}{l}\text { A cooperação com clientes e consumidores influencia } \\
\text { positivamente a apropriação de valor das inovações geradas em } \\
\text { arranjos cooperativos, pelos seus impactos sociais. }\end{array}$ & Não confirmada. \\
\hline H2.4 & $\begin{array}{l}\text { A cooperação com fornecedores influencia positivamente a } \\
\text { apropriação de valor das inovações geradas em arranjos } \\
\text { cooperativos, pelos seus impactos sociais. }\end{array}$ & Não confirmada. \\
\hline H3.4 & $\begin{array}{l}\text { A cooperação com concorrentes influencia positivamente a } \\
\text { apropriação de valor das inovações geradas em arranjos } \\
\text { cooperativos, pelos seus impactos sociais. }\end{array}$ & Não confirmada. \\
\hline H4.4 & $\begin{array}{l}\text { A cooperação com outra empresa do grupo influencia } \\
\text { positivamente a apropriação de valor das inovações geradas em } \\
\text { arranjos cooperativos, pelos seus impactos sociais. }\end{array}$ & Não confirmada. \\
\hline H5.4 & $\begin{array}{l}\text { A cooperação com empresas de consultoria influencia } \\
\text { positivamente a apropriação de valor das inovações geradas em } \\
\text { arranjos cooperativos, pelos seus impactos sociais. }\end{array}$ & Não confirmada. \\
\hline H6.4 & $\begin{array}{l}\text { A cooperação com universidades e institutos de pesquisa } \\
\text { influencia positivamente a apropriação de valor das inovações } \\
\text { geradas em arranjos cooperativos, pelos seus impactos sociais. }\end{array}$ & $\begin{array}{l}\text { Confirmada para o estrato } \\
\text { AT/FR - Médias empresas }\end{array}$ \\
\hline H7.4 & $\begin{array}{l}\text { A cooperação com centros de capacitação profissional e } \\
\text { assistência técnica influencia positivamente a apropriação de } \\
\text { valor das inovações geradas em arranjos cooperativos, pelos } \\
\text { seus impactos socais. }\end{array}$ & $\begin{array}{l}\text { Confirmada para o estrato } \\
\text { AT/FR - Médias empresas }\end{array}$ \\
\hline H8.4 & $\begin{array}{l}\text { A cooperação com instituições de ensaios e certificações } \\
\text { influencia positivamente a apropriação de valor das inovações } \\
\text { geradas em arranjos cooperativos, pelos seus impactos sociais. }\end{array}$ & $\begin{array}{l}\text { Confirmada para o estrato } \\
\text { AT/FR }- \text { Grandes } \\
\text { empresas }\end{array}$ \\
\hline
\end{tabular}

Fonte: Elaboração própria.

Como pode ser observado na tabela 4.21, o modelo estimado $Y_{\text {SocI }}$ referente ao estrato 'AT/FR - Grandes empresas' permitiu confirmar que o coeficiente de regressão $(0,5792)$ para a variável explanatória $X_{C E R T}$ foi estatisticamente significativo para um nível de significância de 5\%, confirmando-se a hipótese H8.4.

A hipótese H6.4 referente à influênica positiva da cooperação com universidades e centros de pesquisa sobre a apropriação de valor das inovações geradas em arranjos cooperativos (impactos sociais) foi confirmada pelo coeficiente de regressão positivo $(0,3797)$ para as empresas de médio porte. Ainda para este estrato, confirmou-se a hipótese H7.4 de que a cooperação com centros de capacitação profissional e assistência técnica influencia positivamente a apropriação de valor das inovações geradas em arranjos cooperativos. O coeficiente de regressão neste caso foi 0,6535 , com sinal positivo.

\subsubsection{5}

\section{Modelos estimados $Y_{R E G U}$}

A seguir, a tabela 4.22 apresenta os resultados obtidos dos coeficientes de regressão em relação aos modelos estimados $Y_{R E G U}$ para micro e pequenas, médias 
e grandes empresas de transformação que implementaram inovações com cooperação interorganizacional em um ambiente setorial de alta tecnologia (AT) e com forte regime de apropriabilidade fraco (FR).

Tabela 4.22 - Resultados das regressões logísticas para os modelos estimados $Y_{R E G U}$ referentes aos estratos AT/FR

\begin{tabular}{|c|c|c|c|c|}
\hline \multicolumn{5}{|c|}{ Modelos estimados $Y_{R E G U}$ referentes aos estratos AT/FR } \\
\hline Parâmetro & $\begin{array}{l}\text { Coeficiente } \\
\text { estimado }(\beta)\end{array}$ & $\begin{array}{l}\text { Erro } \\
\text { padrão }(\varepsilon)\end{array}$ & $\begin{array}{l}\text { Wald } \\
\text { Qui quadrado }\end{array}$ & $\begin{array}{l}\text { Significância } \\
\left(\mathrm{Pr}>\mathrm{X}^{2}\right)\end{array}$ \\
\hline \multicolumn{5}{|c|}{ Estrato AT/FR - Micro e pequenas empresas } \\
\hline Parâmetro & $\begin{array}{l}\text { Coeficiente } \\
\text { estimado }(\beta)\end{array}$ & $\begin{array}{l}\text { Erro } \\
\text { padrão }(\varepsilon)\end{array}$ & $\begin{array}{l}\text { Wald } \\
\text { Qui quadrado }\end{array}$ & $\begin{array}{l}\text { Significância } \\
\left(\operatorname{Pr}>X^{2}\right)\end{array}$ \\
\hline Intercepto & 0,5500 & 0,2293 & 57,558 & $0,0164^{*}$ \\
\hline \multicolumn{5}{|l|}{ Variável explanatória } \\
\hline \multicolumn{5}{|c|}{$\begin{array}{l}\text { Nenhum efeito (adicional) pela entrada das variáveis explanatórias no modelo atendeu ao nível de } \\
\text { significância de } 5 \% \text {. }\end{array}$} \\
\hline $\begin{array}{l}\text { Qualidade de ajuste do } \\
\text { modelo }\end{array}$ & & & Qui quadrado & $\begin{array}{l}\text { Significância } \\
\left(\mathrm{Pr}>\mathrm{X}^{2}\right)\end{array}$ \\
\hline $\begin{array}{l}\text { Capacidade preditiva } \\
\text { (Índice c) }\end{array}$ & - & & & \\
\hline Razão de verossimilhança & - & & & - \\
\hline $\begin{array}{l}\text { Log-verossimilhança } \\
\text { (modelo nulo) }\end{array}$ & 107,701 & & & \\
\hline $\begin{array}{l}\text { Log-verossimilhança } \\
\text { (modelo estimado) }\end{array}$ & - & & & \\
\hline $\begin{array}{l}\text { Teste de Hosmer- } \\
\text { Lemeshow }\end{array}$ & - & & & - \\
\hline Número de casos & 82 & & & \\
\hline \multicolumn{5}{|c|}{ Estrato AT/FR - Médias empresas } \\
\hline Intercepto & 26,790 & 0,6762 & 156,967 & $<0,0001^{* * *}$ \\
\hline \multicolumn{5}{|l|}{ Variável explanatória } \\
\hline$X_{\text {CLIE }}$ & 0,2681 & 0,1353 & 39,272 & $0,0475^{*}$ \\
\hline$X_{C C A P}$ & 0,3782 & 0,1888 & 40,145 & $0,0451^{*}$ \\
\hline $\begin{array}{l}\text { Qualidade de ajuste do } \\
\text { modelo }\end{array}$ & & & Qui quadrado & $\begin{array}{l}\text { Significância } \\
\left(\mathrm{Pr}>X^{2}\right)\end{array}$ \\
\hline $\begin{array}{l}\text { Capacidade preditiva } \\
\text { (Índice c) }\end{array}$ & 0,658 & & & \\
\hline Razão de verossimilhança & & & 112,928 & $0,0035^{\star \star}$ \\
\hline $\begin{array}{l}\text { Log-verossimilhança } \\
\text { (modelo nulo) }\end{array}$ & 202,425 & & & \\
\hline $\begin{array}{l}\text { Log-verossimilhança } \\
\text { (modelo estimado) }\end{array}$ & 191,133 & & & \\
\hline $\begin{array}{l}\text { Teste de Hosmer- } \\
\text { Lemeshow }\end{array}$ & & & 0,3353 & 0,9969 \\
\hline Número de casos & 165 & & & \\
\hline \multicolumn{5}{|c|}{ Estrato AT/FR - Grandes empresas } \\
\hline Intercepto & 24,735 & 0,6244 & 156,916 & $<0,0001^{* * *}$ \\
\hline \multicolumn{5}{|l|}{ Variável explanatória } \\
\hline$X_{C E R T}$ & 0,6918 & 0,1949 & 125,958 & $0,0004^{* * *}$ \\
\hline $\begin{array}{l}\text { Qualidade de ajuste do } \\
\text { modelo }\end{array}$ & & & Qui quadrado & $\begin{array}{l}\text { Significância } \\
\left(\mathrm{Pr}>X^{2}\right)\end{array}$ \\
\hline $\begin{array}{l}\text { Capacidade preditiva } \\
\text { (Índice c) }\end{array}$ & 0,713 & & & \\
\hline Razão de verossimilhança & & & 146,261 & $0,0001^{* * *}$ \\
\hline $\begin{array}{l}\text { Log-verossimilhança } \\
\text { (modelo nulo) }\end{array}$ & 133,763 & & & \\
\hline $\begin{array}{l}\text { Log-verossimilhança } \\
\text { (modelo estimado) }\end{array}$ & 119,137 & & & \\
\hline $\begin{array}{l}\text { Teste de Hosmer- } \\
\text { Lemeshow }\end{array}$ & & & 16,725 & 0,4333 \\
\hline Número de casos & 101 & & & \\
\hline
\end{tabular}


Para o extrato 'AT/FR - Micro e pequenas empresas', não foi possível estimar o modelo de regressão $Y_{R E G U}$ pelos resultados iniciais da aplicação do procedimento Stepwise, que indicaram que nenhum efeito (adicional) pela entrada das variáveis explanatórias nos referidos modelo atenderia ao nível de significância de 5\%.

A análise dos resultados apresentados na tabela 4.22, visando testar as hipóteses de pesquisa relativas aos modelos estimados $Y_{R E G U}$ para os demais estratos AT/FR permitiu a confirmação das hipóteses H1.5, H7.5 e H8.5, conforme mostrado no quadro 4.16 .

Quadro 4.16 - Resultados das hipóteses de pesquisa dos modelos $Y_{R E G U}$ referentes aos estratos AT/FR

\begin{tabular}{|c|c|c|}
\hline Hipótese & Descrição & Resultado \\
\hline H1.5 & $\begin{array}{l}\text { A cooperação com clientes e consumidores influencia } \\
\text { positivamente a apropriação de valor das inovações geradas } \\
\text { em arranjos cooperativos, pelos seus impactos regulatórios. }\end{array}$ & $\begin{array}{l}\text { Confirmada para o estrato } \\
\text { AT/FR - Médias empresas. }\end{array}$ \\
\hline H2.5 & $\begin{array}{l}\text { A cooperação com fornecedores influencia positivamente a } \\
\text { apropriação de valor das inovações geradas em arranjos } \\
\text { cooperativos, pelos seus impactos regulatórios. }\end{array}$ & Não confirmada. \\
\hline H3.5 & $\begin{array}{l}\text { A cooperação com concorrentes influencia positivamente a } \\
\text { apropriação de valor das inovações geradas em arranjos } \\
\text { cooperativos, pelos seus impactos regulatórios. }\end{array}$ & Não confirmada. \\
\hline H4.5 & $\begin{array}{l}\text { A cooperação com outra empresa do grupo influencia } \\
\text { positivamente a apropriação de valor das inovações geradas } \\
\text { em arranjos cooperativos, pelos seus impactos regulatórios. }\end{array}$ & Não confirmada. \\
\hline H5.5 & $\begin{array}{l}\text { A cooperação com empresas de consultoria influencia } \\
\text { positivamente a apropriação de valor das inovações geradas } \\
\text { em arranjos cooperativos, pelos seus impactos regulatórios. }\end{array}$ & Não confirmada. \\
\hline H6.5 & $\begin{array}{l}\text { A cooperação com universidades e institutos de pesquisa } \\
\text { influencia positivamente a apropriação de valor das } \\
\text { inovações geradas em arranjos cooperativos, pelos seus } \\
\text { impactos regulatórios. }\end{array}$ & Não confirmada. \\
\hline H7.5 & $\begin{array}{l}\text { A cooperação com centros de capacitação profissional e } \\
\text { assistência técnica influencia positivamente a apropriação de } \\
\text { valor das inovações geradas em arranjos cooperativos, pelos } \\
\text { seus impactos regulatórios. }\end{array}$ & $\begin{array}{l}\text { Confirmada para o estrato } \\
\text { AT/FR - Médias empresas. }\end{array}$ \\
\hline H8.5 & $\begin{array}{l}\text { A cooperação com instituições de ensaios e certificações } \\
\text { influencia positivamente a apropriação de valor das } \\
\text { inovações geradas em arranjos cooperativos, pelos seus } \\
\text { impactos regulatórios. }\end{array}$ & $\begin{array}{l}\text { Confirmada para o estrato } \\
\text { AT/FR - Grandes empresas. }\end{array}$ \\
\hline
\end{tabular}

Fonte: Elaboração própria.

O modelo estimado $Y_{R E G U}$ referente ao estrato 'AT/FR - Grandes empresas' permitiu confirmar que o coeficiente de regressão $(0,6918)$ para a variável explanatória $X_{C E R T}$ foi estatisticamente significativo para um nível de significância de 5\%. Confirmou-se assim a hipótese H8.5 para este estrato.

A cooperação com clientes e consumidores influenciando positivamente a apropriação de valor das inovações geradas em arranjos cooperativos (expressa pelos seus impactos regulatórios), foi confirmada (H5.5) para o estrato 'AT/FR Médias empresas'. O coeficiente de regressão foi 0,2681 e seu sinal é positivo. 
Ainda para esse mesmo estrato, confirmou-se a hipótese H7.5 referente à influência positiva da cooperação das médias empresas com centros de capacitação profissional e assistência técnica sobre a apropriação de valor das inovações tecnológicas geradas nesses arranjos cooperativos (coeficiente de regressão $=0,3782$ ).

\subsubsection{6}

\section{Discussão dos resultados do agrupamento setorial AT/FR}

Quando o ambiente setorial é de alta intensidade tecnológica, porém com regime de apropriabilidade fraco (AT/FR), as micro e pequenas empresas desses setores buscam cooperação com outras organizações com o objetivo de inovar para melhorar seus processos de produção e as condições de saúde e segurança para seus colaboradores e/ou clientes. Para tal, os parceiros de escolha são empresas de consultoria e centros de capacitação e formação profissional.

Por sua vez, as médias empresas buscam cooperação interorganizacional com diversos objetivos, desde melhorias e/ou mudanças nos processos de produção até atendimento a requisitos de regulamentos técnicos e normas aplicáveis. Os principais parceiros nestes casos foram os centros de capacitação profissional, sendo que a apropriação de valor pelas inovações geradas nesses arranjos cooperativos refere-se aos impactos na produção; ambientais; sociais; e regulatórios. Universidades e institutos de pesquisa influenciaram positivamente a geração de inovaçãoes e apropriação de valor, expressa preponderamente pelos impactos spciais. A cooperação com instituições de ensaios e certificações geraram inovações com impactos no mercado, especialmente entrada em novos mercados com exigências normativas e regulatórias.

As empresas brasileiras de grande porte da indústria de transformação também buscaram cooperação interorganizacional com diversos objetivos de inovação, desde melhorias e/ou mudanças nos processos de produção até atendimento a requisitos de regulamentos e normas aplicáveis. Os principais parceiros nestes casos foram as instituições de ensaios e certificações para a criação de inovações com impactos regulatórios (atendimento a requisitos legais e/ou de normas aplicáveis) e sociais (questões de segurança e saúde ocupacional). Outros parceiros importantes deste grupo foram fornecedores que, juntamente com as grandes empresas, geraram inovações com impactos na produção e 
ambientais nas respectivas cadeias de produção. Universidades e institutos de pesquisa não foram apontados como parceiros em projetos de PD\&I, apesar dos esforços institucionais e políticas públicas voltadas para maior interação universidade-empresa.

\subsection{3}

Análise da influência dos parceiros em arranjos cooperativos sobre a apropriação de valor das inovações geradas: agrupamento setorial BT/FO

As tabelas 4.23 a 4.27 , a seguir, apresentam as estimativas dos coeficientes de regressão em relação aos modelos logit para empresas do agrupamento setorial BT/FO da indústria de transformação no Brasil, que implementaram inovações em arranjos cooperativos com outras organizações no período de 2012 a 2014.

\subsubsection{1}

\section{Modelos estimados $Y_{M E R C}$}

Tabela 4.23 - Resultados das regressões logísticas para os modelos estimados YMERC referentes aos estratos BT/FO

\begin{tabular}{|c|c|c|c|c|}
\hline \multicolumn{5}{|c|}{ Modelos estimados $Y_{M E R C}$ referentes aos estratos BT/FO } \\
\hline Parâmetro & $\begin{array}{l}\text { Coeficiente } \\
\text { estimado }(\beta)\end{array}$ & $\begin{array}{l}\text { Erro } \\
\text { padrão }(\varepsilon)\end{array}$ & $\begin{array}{l}\text { Wald } \\
\text { Qui quadrado }\end{array}$ & $\begin{array}{l}\text { Significância } \\
\left(\operatorname{Pr}>X^{2}\right)\end{array}$ \\
\hline \multicolumn{5}{|c|}{ Estrato BT/FO - Micro e pequenas empresas } \\
\hline Intercepto & 15,339 & 11,347 & 18,275 & 0,1764 \\
\hline \multicolumn{5}{|l|}{ Variável explanatória } \\
\hline$X_{E M P R}$ & 0,6961 & 0,3033 & 52,685 & $0,0217^{*}$ \\
\hline $\begin{array}{l}\text { Qualidade de ajuste do } \\
\text { modelo }\end{array}$ & & & Qui quadrado & $\begin{array}{l}\text { Significância } \\
\left(\mathrm{Pr}>\mathrm{X}^{2}\right)\end{array}$ \\
\hline $\begin{array}{l}\text { Capacidade preditiva } \\
\text { (Índice c) }\end{array}$ & 0,609 & & & \\
\hline Razão de verossimilhança & & & 57,989 & $0,0160^{*}$ \\
\hline $\begin{array}{l}\text { Log-verossimilhança } \\
\text { (modelo nulo) }\end{array}$ & 77,346 & & & \\
\hline $\begin{array}{l}\text { Log-verossimilhança } \\
\text { (modelo estimado) }\end{array}$ & 71,547 & & & \\
\hline $\begin{array}{l}\text { Teste de Hosmer- } \\
\text { Lemeshow }\end{array}$ & & & 0,6250 & 0,4292 \\
\hline Número de casos & 66 & & & \\
\hline \multicolumn{5}{|c|}{ Estrato BT/FO - Médias empresas } \\
\hline Intercepto & 14,328 & 0,2429 & 348,061 & $<0,0001^{* \star *}$ \\
\hline \multicolumn{5}{|c|}{ Variável explanatória } \\
\hline \multicolumn{5}{|c|}{$\begin{array}{l}\text { Nenhum efeito (adicional) pela entrada das variáveis explanatórias no modelo atendeu ao nível de } \\
\text { significância de } 5 \% \text {. }\end{array}$} \\
\hline $\begin{array}{l}\text { Qualidade de ajuste do } \\
\text { modelo }\end{array}$ & & & Qui quadrado & $\begin{array}{l}\text { Significância } \\
\left(\mathrm{Pr}>X^{2}\right)\end{array}$ \\
\hline $\begin{array}{l}\text { Capacidade preditiva } \\
\text { (Índice c) }\end{array}$ & - & & & \\
\hline Razão de verossimilhança & - & & & - \\
\hline $\begin{array}{l}\text { Log-verossimilhança } \\
\text { (modelo nulo) }\end{array}$ & 106,833 & & & \\
\hline $\begin{array}{l}\text { Log-verossimilhança } \\
\text { (modelo estimado) }\end{array}$ & - & & & \\
\hline $\begin{array}{l}\text { Teste de Hosmer- } \\
\text { Lemeshow }\end{array}$ & - & & & - \\
\hline Número de casos & 109 & & & \\
\hline
\end{tabular}


Tabela 4.23 - Resultados das regressões logísticas para os modelos estimados YMERC referentes aos estratos BT/FO (cont.)

\begin{tabular}{|c|c|c|c|c|}
\hline \multicolumn{5}{|c|}{ Modelos estimados $Y_{\text {MERC }}$ referentes aos estratos BT/FO } \\
\hline Parâmetro & $\begin{array}{l}\text { Coeficiente } \\
\text { estimado }(\beta)\end{array}$ & $\begin{array}{l}\text { Erro } \\
\text { padrão }(\varepsilon)\end{array}$ & $\begin{array}{l}\text { Wald } \\
\text { Qui quadrado }\end{array}$ & $\begin{array}{l}\text { Significância } \\
\left(\mathrm{Pr}>\mathrm{X}^{2}\right)\end{array}$ \\
\hline \multicolumn{5}{|c|}{ Estrato BT/FO - Grandes empresas } \\
\hline Intercepto & 42,734 & 0,8874 & 231,890 & \\
\hline \multicolumn{5}{|l|}{ Variável explanatória } \\
\hline$X_{C L I E}$ & 11,631 & 0,2679 & 188,555 & $<0,0001^{* * *}$ \\
\hline $\begin{array}{l}\text { Qualidade de ajuste do } \\
\text { modelo }\end{array}$ & & & Qui quadrado & $\begin{array}{l}\text { Significância } \\
\left(\mathrm{Pr}>\mathrm{X}^{2}\right)\end{array}$ \\
\hline $\begin{array}{l}\text { Capacidade preditiva } \\
\text { (Índice c) }\end{array}$ & 0,851 & & & \\
\hline Razão de verossimilhança & & & 268,982 & $<0,0001^{* * *}$ \\
\hline $\begin{array}{l}\text { Log-verossimilhança } \\
\text { (modelo nulo) }\end{array}$ & 89,302 & & & \\
\hline $\begin{array}{l}\text { Log-verossimilhança } \\
\text { (modelo estimado) }\end{array}$ & 62,404 & & & \\
\hline $\begin{array}{l}\text { Teste de Hosmer- } \\
\text { Lemeshow }\end{array}$ & & & 14,457 & 0,4854 \\
\hline Número de casos & 83 & & & \\
\hline
\end{tabular}

Com relação ao extrato 'BT/FO - Médias empresas', não foi possível estimar o modelo de regressão $Y_{M E R C}$ pelos resultados iniciais da aplicação do procedimento Stepwise, que indicaram que nenhum efeito (adicional) pela entrada das variáveis explanatórias no referido modelo atenderia ao nível de significância de $5 \%$.

A avaliação da qualidade de ajuste dos modelos $Y_{M E R C}$ referentes aos outros dois estratos do agrupamento setorial BT/FO indicou que as capacidades preditivas destes modelos, medidas pelo Índice c, atingiram valores ente 0,609 e 0,851 .

Verificou-se também que as estatísticas da log-verosimilhança confirmaram a significância global dos modelos, quando se compram os valores dos modelos estimados aos valores superiores observados nos respectivos modelos nulos. Ainda, como nos modelos apresentados anteriormente, todas as estimativas dos parâmetros da regressão deste modelo foram estatisticamente significativas ao nível de $5 \%$.

Com o objetivo de testar as hipóteses de pesquisa relativas aos modelos estimados $Y_{M E R C}$ para estratos referentes aos estratos $\mathrm{BT} / \mathrm{FO}$, procedeu-se à análise dos resultados apresentados na tabela 4.23, como mostra o quadro 4.17, a seguir. 
A análise dos resultados apresentados na tabela 4.23, visando testar as hipóteses de pesquisa relativas aos modelos estimados $Y_{M E R C}$ para os demais estratos BT/FO permitiu a confirmação das hipóteses H1.1 e H4.1, conforme mostrado no quadro 4.17 (apresentado adiante).

O modelo estimado $Y_{M E R C}$ referente ao estrato 'BT/FO - Grandes empresas' permitiu confirmar que o coeficiente de regressão $(11,631)$ para a variável explanatória $X_{C L I E}$ foi estatisticamente significativo para um nível de significância de 5\%. Confirmou-se assim a hipótese H1.1 para este estrato.

A cooperação com outra empresa do grupo influenciando positivamente a apropriação de valor das inovações geradas em arranjos cooperativos foi confirmada (H4.1) para o estrato 'BT/F0 - Micro e pequenas empresas'. O coeficiente de regressão para a variável explanatória $X_{E M P}$ foi estatisticamente significativo para um nível de significância de 5\% (valor $=0,6961)$ e seu sinal é positivo.

Quadro 4.17 - Resultados das hipóteses de pesquisa dos modelos $Y_{M E R C}$ referentes aos estratos BT/FO

\begin{tabular}{|c|c|c|}
\hline Hipótese & Descrição & Resultado \\
\hline H1.1 & $\begin{array}{l}\text { A cooperação com clientes e consumidores influencia } \\
\text { positivamente a apropriação de valor das inovações geradas } \\
\text { em arranjos cooperativos, pelos seus impactos } \\
\text { mercadológicos. }\end{array}$ & $\begin{array}{l}\text { Confirmada para o estrato } \\
\text { BT/FO - Grandes empresas }\end{array}$ \\
\hline H2.1 & $\begin{array}{l}\text { A cooperação com fornecedores influencia positivamente a } \\
\text { apropriação de valor das inovações geradas em arranjos } \\
\text { cooperativos, pelos seus impactos mercadológicos. }\end{array}$ & Não confirmada. \\
\hline H3.1 & $\begin{array}{l}\text { A cooperação com concorrentes influencia positivamente a } \\
\text { apropriação de valor das inovações geradas em arranjos } \\
\text { cooperativos, pelos seus impactos mercadológicos. }\end{array}$ & Não confirmada. \\
\hline H4.1 & $\begin{array}{l}\text { A cooperação com outra empresa do grupo influencia } \\
\text { positivamente a apropriação de valor das inovações geradas } \\
\text { em arranjos cooperativos, pelos seus impactos } \\
\text { mercadológicos. }\end{array}$ & $\begin{array}{l}\text { Confirmada para o estrato } \\
\text { BT/FO - Micro e pequenas } \\
\text { empresas }\end{array}$ \\
\hline H5.1 & $\begin{array}{l}\text { A cooperação com empresas de consultoria influencia } \\
\text { positivamente a apropriação de valor das inovações geradas } \\
\text { em arranjos cooperativos, pelos seus impactos } \\
\text { mercadológicos. }\end{array}$ & Não confirmada. \\
\hline H6.1 & $\begin{array}{l}\text { A cooperação com universidades e institutos de pesquisa } \\
\text { influencia positivamente a apropriação de valor das } \\
\text { inovações geradas em arranjos cooperativos, pelos seus } \\
\text { impactos mercadológicos. }\end{array}$ & Não confirmada. \\
\hline H7.1 & $\begin{array}{l}\text { A cooperação com centros de capacitação profissional e } \\
\text { assistência técnica influencia positivamente a apropriação de } \\
\text { valor das inovações geradas em arranjos cooperativos, pelos } \\
\text { seus impactos mercadológicos. }\end{array}$ & Não confirmada. \\
\hline H8.1 & $\begin{array}{l}\text { A cooperação com instituições de ensaios e certificações } \\
\text { influencia positivamente a apropriação de valor das } \\
\text { inovações geradas em arranjos cooperativos, pelos seus } \\
\text { impactos mercadológicos. }\end{array}$ & Não confirmada. \\
\hline
\end{tabular}

Fonte: Elaboração própria. 


\subsubsection{2 \\ Modelos estimados YPROD}

A tabela 4.24 reúne os resultados obtidos dos coeficientes de regressão em relação aos modelos estimados $Y_{P R O D}$ para micro e pequenas, médias e grandes empresas de transformação que implementaram inovações com cooperação interorganizacional em um ambiente setorial de baixa tecnologia (BT) e com regime de apropriabilidade forte (FO).

Para o extrato - 'BT/FO - Micro e pequenas empresas', não foi possível estimar o modelo de regressão $Y_{P R O D}$ pelos resultados iniciais da aplicação do procedimento Stepwise, que indicaram que nenhum efeito (adicional) pela entrada das variáveis explanatórias no referido modelo atenderia ao nível de significância de $5 \%$.

Tabela 4.24 - Resultados das regressões logísticas para os modelos estimados $Y_{P R O D}$ referentes aos estratos BT/FO

\begin{tabular}{|c|c|c|c|c|}
\hline \multicolumn{5}{|c|}{ Modelos estimados $Y_{P R O D}$ referentes aos estratos BT/F0 } \\
\hline Parâmetro & $\begin{array}{l}\text { Coeficiente } \\
\text { estimado }(\beta)\end{array}$ & $\begin{array}{l}\text { Erro } \\
\text { padrão }(\varepsilon)\end{array}$ & $\begin{array}{l}\text { Wald } \\
\text { Qui quadrado }\end{array}$ & $\begin{array}{l}\text { Significância } \\
\left(\operatorname{Pr}>X^{2}\right)\end{array}$ \\
\hline \multicolumn{5}{|c|}{ Estrato BT/FO - Micro e pequenas empresas } \\
\hline Intercepto & 0,5596 & 0,2559 & 47,830 & $0,0287^{*}$ \\
\hline \multicolumn{5}{|c|}{ Variável explanatória } \\
\hline \multicolumn{5}{|c|}{$\begin{array}{l}\text { Pelo procedimento Stepwise, a variável } X_{\text {CLIE }} \text { foi removida. Sua inserção no modelo não atendeu ao } \\
\text { critério da estatítica de Wald. }\end{array}$} \\
\hline $\begin{array}{l}\text { Qualidade de ajuste do } \\
\text { modelo }\end{array}$ & & & Qui quadrado & $\begin{array}{l}\text { Significância } \\
\left(\operatorname{Pr}>X^{2}\right)\end{array}$ \\
\hline $\begin{array}{l}\text { Capacidade preditiva } \\
\text { (Índice c) }\end{array}$ & - & & & \\
\hline Razão de verossimilhança & - & & & - \\
\hline $\begin{array}{l}\text { Log-verossimilhança } \\
\text { (modelo nulo) }\end{array}$ & 86,524 & & & \\
\hline $\begin{array}{l}\text { Log-verossimilhança } \\
\text { (modelo estimado) }\end{array}$ & - & & & \\
\hline $\begin{array}{l}\text { Teste de Hosmer- } \\
\text { Lemeshow }\end{array}$ & - & & & - \\
\hline Número de casos & 66 & & & \\
\hline \multicolumn{5}{|c|}{ Estrato BT/FO - Médias empresas } \\
\hline Intercepto & 18,290 & 0,6860 & 71,087 & $0,0077^{* *}$ \\
\hline \multicolumn{5}{|l|}{ Variável explanatória } \\
\hline$X_{I C T S}$ & 0,4695 & 0,1935 & 58,898 & $0,0152^{*}$ \\
\hline $\begin{array}{l}\text { Qualidade de ajuste do } \\
\text { modelo }\end{array}$ & & & Qui quadrado & $\begin{array}{l}\text { Significância } \\
\left(\operatorname{Pr}>X^{2}\right)\end{array}$ \\
\hline $\begin{array}{l}\text { Capacidade preditiva } \\
\text { (Índice c) }\end{array}$ & 0,619 & & & \\
\hline Razão de verossimilhança & & & 66,414 & $0,0100^{*}$ \\
\hline $\begin{array}{l}\text { Log-verossimilhança } \\
\text { (modelo nulo) }\end{array}$ & 149,035 & & & \\
\hline $\begin{array}{l}\text { Log-verossimilhança } \\
\text { (modelo estimado) }\end{array}$ & 142,394 & & & \\
\hline $\begin{array}{l}\text { Teste de Hosmer- } \\
\text { Lemeshow }\end{array}$ & & & 0,8563 & 0,6517 \\
\hline Número de casos & 109 & & & \\
\hline
\end{tabular}


Tabela 4.24 - Resultados das regressões logísticas para os modelos estimados YPROD referentes aos estratos BT/FO (cont.)

\begin{tabular}{|c|c|c|c|c|}
\hline \multicolumn{5}{|c|}{ Modelos estimados $Y_{P R O D}$ referentes aos estratos BT/F0 } \\
\hline Parâmetro & $\begin{array}{l}\text { Coeficiente } \\
\text { estimado }(\beta)\end{array}$ & $\begin{array}{l}\text { Erro } \\
\text { padrão }(\varepsilon)\end{array}$ & $\begin{array}{l}\text { Wald } \\
\text { Qui quadrado }\end{array}$ & $\begin{array}{l}\text { Significância } \\
\left(\mathrm{Pr}>\mathrm{X}^{2}\right)\end{array}$ \\
\hline \multicolumn{5}{|c|}{ Estrato BT/FO - Grandes empresas } \\
\hline Intercepto & 14,590 & 0,4694 & 96,616 & $0,0019^{* *}$ \\
\hline \multicolumn{5}{|l|}{ Variável explanatória } \\
\hline$X_{C L I E}$ & 0,4264 & 0,1789 & 56,830 & $0,0171^{*}$ \\
\hline $\begin{array}{l}\text { Qualidade de ajuste do } \\
\text { modelo }\end{array}$ & & & Qui quadrado & $\begin{array}{l}\text { Significância } \\
\left(\operatorname{Pr}>X^{2}\right)\end{array}$ \\
\hline $\begin{array}{l}\text { Capacidade preditiva } \\
\text { (Índice c) }\end{array}$ & 0,654 & & & \\
\hline Razão de verossimilhança & & & 58,800 & $0,0153^{*}$ \\
\hline $\begin{array}{l}\text { Log-verossimilhança } \\
\text { (modelo nulo) }\end{array}$ & 109,691 & & & \\
\hline $\begin{array}{l}\text { Log-verossimilhança } \\
\text { (modelo estimado) }\end{array}$ & 103,811 & & & \\
\hline $\begin{array}{l}\text { Teste de Hosmer- } \\
\text { Lemeshow }\end{array}$ & & & 47,888 & 0,0912 \\
\hline Número de casos & 83 & & & \\
\hline
\end{tabular}

A avaliação da qualidade de ajuste dos modelos $Y_{P R O D}$ referentes aos outros dois estratos do agrupamento setorial BT/FO indicou que as capacidades preditivas destes modelos, medidas pelo Índice c, atingiram valores próximos $(0,619$ e 0,654 , respectivamente). Como nos modelos apresentados anteriormente, todas as estimativas dos parâmetros da regressão deste modelo foram estatisticamente significativas ao nível de 5\%.

$\mathrm{Na}$ sequência, procedeu-se a análise dos resultados apresentados na tabela 4.24 , visando testar as hipóteses de pesquisa relativas aos modelos estimados $Y_{P R O D}$ para estratos referentes aos estratos BT/FO (quadro 4.18, ao final deste item).

Como pode ser observado na tabela 4.24, o modelo estimado $Y_{P R O D}$ referente ao estrato 'BT/FO - Médias empresas' permitiu confirmar que o coeficiente estimado $(0,4695)$ para a variável explanatória $X_{I C T S}$ foi estatisticamente significativo para um nível de significância de 5\%. Assim, rejeitou-se a hipótese nula de que não existia relação entre a referida variável explanatória e a variável dependente e confirmou-se a hipótese H6.2. A hipótese de cooperação com clientes e consumidores influenciando positivamente a apropriação de valor das inovações geradas em arranjos cooperativos, pelos seus impactos na produção, foi 
confirmada com o sinal do coeficiente de regressão positivo $(0,4264)$ para as grandes empresas deste agrupamento setorial (hipótese H1.2 confirmada).

Quadro 4.18 - Resultados das hipóteses de pesquisa dos modelos $Y_{P R O D}$ referentes aos estratos BT/FO

\begin{tabular}{|c|c|c|}
\hline Hipótese & Descrição & Resultado \\
\hline H1.2 & $\begin{array}{l}\text { A cooperação com clientes e consumidores influencia } \\
\text { positivamente a apropriação de valor das inovações geradas } \\
\text { em arranjos cooperativos, pelos seus impactos na produção. }\end{array}$ & $\begin{array}{l}\text { Confirmada para o estrato } \\
\text { BT/FO - Grandes } \\
\text { empresas }\end{array}$ \\
\hline H2.2 & $\begin{array}{l}\text { A cooperação com fornecedores influencia positivamente a } \\
\text { apropriação de valor das inovações geradas em arranjos } \\
\text { cooperativos, pelos seus impactos na produção. }\end{array}$ & Não confirmada. \\
\hline H3.2 & $\begin{array}{l}\text { A cooperação com concorrentes influencia positivamente a } \\
\text { apropriação de valor das inovações geradas em arranjos } \\
\text { cooperativos, pelos seus impactos na produção. }\end{array}$ & Não confirmada. \\
\hline H4.2 & $\begin{array}{l}\text { A cooperação com outra empresa do grupo influencia } \\
\text { positivamente a apropriação de valor das inovações geradas } \\
\text { em arranjos cooperativos, pelos seus impactos na produção. }\end{array}$ & Não confirmada. \\
\hline H5.2 & $\begin{array}{l}\text { A cooperação com empresas de consultoria influencia } \\
\text { positivamente a apropriação de valor das inovações geradas } \\
\text { em arranjos cooperativos, pelos seus impactos na produção. }\end{array}$ & Não confirmada. \\
\hline H6.2 & $\begin{array}{l}\text { A cooperação com universidades e institutos de pesquisa } \\
\text { influencia positivamente a apropriação de valor das inovações } \\
\text { geradas em arranjos cooperativos, pelos seus impactos na } \\
\text { produção. }\end{array}$ & $\begin{array}{l}\text { Confirmada para o estrato } \\
\text { BT/FO - Médias empresas }\end{array}$ \\
\hline H7.2 & $\begin{array}{l}\text { A cooperação com centros de capacitação profissional e } \\
\text { assistência técnica influencia positivamente a apropriação de } \\
\text { valor das inovações geradas em arranjos cooperativos, pelos } \\
\text { seus impactos na produção. }\end{array}$ & Não confirmada. \\
\hline H8.2 & $\begin{array}{l}\text { A cooperação com instituições de ensaios e certificações } \\
\text { influencia positivamente a apropriação de valor das inovações } \\
\text { geradas em arranjos cooperativos, pelos seus impactos na } \\
\text { produção. }\end{array}$ & Não confirmada. \\
\hline
\end{tabular}

\subsubsection{3}

\section{Modelos estimados $Y_{A M B I}$}

Tabela 4.25 - Resultados das regressões logísticas para os modelos estimados Y $_{\text {AMBI }}$ referentes aos estratos $\mathrm{BT} / \mathrm{FO}$

\begin{tabular}{|c|c|c|c|c|}
\hline \multicolumn{5}{|c|}{ Modelos estimados $Y_{A M B I}$ referentes aos estratos BT/FO } \\
\hline Parâmetro & $\begin{array}{l}\text { Coeficiente } \\
\text { estimado }(\beta)\end{array}$ & $\begin{array}{l}\text { Erro } \\
\text { padrão }(\varepsilon)\end{array}$ & $\begin{array}{l}\text { Wald } \\
\text { Qui quadrado }\end{array}$ & $\begin{array}{l}\text { Significância } \\
\left(P r>X^{2}\right)\end{array}$ \\
\hline \multicolumn{5}{|c|}{ Estrato BT/FO - Micro e pequenas empresas } \\
\hline Intercepto & 12,238 & 0,2937 & 173,589 & $<0,0001^{* * *}$ \\
\hline \multicolumn{5}{|c|}{ Variável explanatória } \\
\hline \multicolumn{5}{|c|}{$\begin{array}{l}\text { Nenhum efeito (adicional) pela entrada das variáveis explanatórias no modelo atendeu ao nível de } \\
\text { significância de } 5 \% \text {. }\end{array}$} \\
\hline $\begin{array}{l}\text { Qualidade de ajuste do } \\
\text { modelo }\end{array}$ & & & Qui quadrado & $\begin{array}{l}\text { Significância } \\
\left(\operatorname{Pr}>X^{2}\right)\end{array}$ \\
\hline $\begin{array}{l}\text { Capacidade preditiva } \\
\text { (Índice c) }\end{array}$ & - & & & \\
\hline Razão de verossimilhança & & & - & - \\
\hline $\begin{array}{l}\text { Log-verossimilhança } \\
\text { (Modelo nulo) }\end{array}$ & 70,747 & & & \\
\hline $\begin{array}{l}\text { Log-verossimilhança } \\
\text { (Modelo estimado) }\end{array}$ & - & & & \\
\hline $\begin{array}{l}\text { Teste de Hosmer- } \\
\text { Lemeshow }\end{array}$ & & & - & - \\
\hline Número de casos & 66 & & & \\
\hline
\end{tabular}


Tabela 4.25 - Resultados das regressões logísticas para os modelos estimados YAMBI $_{\text {A }}$ referentes aos estratos BT/FO (cont.)

\begin{tabular}{|c|c|c|c|c|}
\hline \multicolumn{5}{|c|}{ Modelos estimados $Y_{A M B I}$ referentes aos estratos BT/FO } \\
\hline Parâmetro & $\begin{array}{l}\text { Coeficiente } \\
\text { estimado }(\beta)\end{array}$ & $\begin{array}{l}\text { Erro } \\
\text { padrão }(\varepsilon)\end{array}$ & $\begin{array}{l}\text { Wald } \\
\text { Qui quadrado }\end{array}$ & $\begin{array}{l}\text { Significância } \\
\left(\operatorname{Pr}>X^{2}\right)\end{array}$ \\
\hline \multicolumn{5}{|c|}{ Estrato BT/FO - Médias empresas } \\
\hline Intercepto & 10,787 & 0,8424 & 16,398 & 0,2004 \\
\hline \multicolumn{5}{|l|}{ Variável explanatória } \\
\hline$X_{E M P R}$ & 0,4342 & 0,1753 & 61,340 & $0,0133^{*}$ \\
\hline$X_{\text {ICTS }}$ & 0,7102 & 0,2567 & 76,534 & $0,0057^{\star *}$ \\
\hline$X_{C E R T}$ & 0,4815 & 0,2455 & 38,453 & $0,0499^{*}$ \\
\hline $\begin{array}{l}\text { Qualidade de ajuste do } \\
\text { modelo }\end{array}$ & & & Qui quadrado & $\begin{array}{l}\text { Significância } \\
\left(\mathrm{Pr}>\mathrm{X}^{2}\right)\end{array}$ \\
\hline $\begin{array}{l}\text { Capacidade preditiva } \\
\text { (Índice c) }\end{array}$ & 0,753 & & & \\
\hline Razão de verossimilhança & & & 135,427 & $0,0036^{* *}$ \\
\hline $\begin{array}{l}\text { Log-verossimilhança } \\
\text { (modelo nulo) }\end{array}$ & 124,210 & & & \\
\hline $\begin{array}{l}\text { Log-verossimilhança } \\
\text { (modelo estimado) }\end{array}$ & 110,667 & & & \\
\hline $\begin{array}{l}\text { Teste de Hosmer- } \\
\text { Lemeshow }\end{array}$ & & & 59,688 & 0,5434 \\
\hline Número de casos & 109 & & & \\
\hline \multicolumn{5}{|c|}{ Estrato BT/FO - Grandes empresas } \\
\hline Intercepto & 29,295 & 0,8286 & 124,994 & $0,0004^{* * *}$ \\
\hline \multicolumn{5}{|l|}{ Variável explanatória } \\
\hline$X_{\text {CLIE }}$ & 0,5222 & 0,2041 & 65,447 & $0,0105^{*}$ \\
\hline$X_{\text {CONS }}$ & 0,7022 & 0,2126 & 109,105 & $0,0010^{* *}$ \\
\hline $\begin{array}{l}\text { Qualidade de ajuste do } \\
\text { modelo }\end{array}$ & & & Qui quadrado & $\begin{array}{l}\text { Significância } \\
\left(\mathrm{Pr}>\mathrm{X}^{2}\right)\end{array}$ \\
\hline $\begin{array}{l}\text { Capacidade preditiva } \\
\text { (Índice c) }\end{array}$ & 0,788 & & & \\
\hline Razão de verossimilhança & & & 192,264 & $<0,0001^{\star * *}$ \\
\hline $\begin{array}{l}\text { Log-verossimilhança } \\
\text { (modelo nulo) }\end{array}$ & 114,761 & & & \\
\hline $\begin{array}{l}\text { Log-verossimilhança } \\
\text { (modelo estimado) }\end{array}$ & 95,535 & & & \\
\hline $\begin{array}{l}\text { Teste de Hosmer- } \\
\text { Lemeshow }\end{array}$ & & & 43,907 & 0,6240 \\
\hline Número de casos & 83 & & & \\
\hline
\end{tabular}

Na sequência, procedeu-se a análise dos resultados apresentados na tabela 4.25 para testar as hipóteses de pesquisa relativas aos modelos estimados $Y_{A M B I}$ para os três estratos do agrupamento setorial BT/FO. Confirmaram-se as hipóteses H1.3; H4.3; H5.3; H6.3 e H8.3, como mostra o quadro 4.19. 
Quadro 4.19 - Resultados das hipóteses de pesquisa dos modelos $Y_{A M B I}$ referentes aos estratos BT/FO

\begin{tabular}{|c|c|c|}
\hline Hipótese & Descrição & Resultado \\
\hline H1.3 & $\begin{array}{l}\text { A cooperação com clientes e consumidores influencia } \\
\text { positivamente a apropriação de valor das inovações } \\
\text { geradas em arranjos cooperativos, pelos seus impactos } \\
\text { ambientais. }\end{array}$ & $\begin{array}{l}\text { Confirmada para o estrato } \\
\text { BT/FO - Grandes empresas } \\
\text { Coeficiente estimado } \quad(\beta) \\
0,5222\end{array}$ \\
\hline H2.3 & $\begin{array}{l}\text { A cooperação com fornecedores influencia positivamente } \\
\text { a apropriação de valor das inovações geradas em } \\
\text { arranjos cooperativos, pelos seus impactos ambientais. }\end{array}$ & Não confirmada. \\
\hline H3.3 & $\begin{array}{l}\text { A cooperação com concorrentes influencia } \\
\text { positivamente a apropriação de valor das inovações } \\
\text { geradas em arranjos cooperativos, pelos seus impactos } \\
\text { ambientais. }\end{array}$ & Não confirmada. \\
\hline H4.3 & $\begin{array}{l}\text { A cooperação com outra empresa do grupo influencia } \\
\text { positivamente a apropriação de valor das inovações } \\
\text { geradas em arranjos cooperativos, pelos seus impactos } \\
\text { ambientais. }\end{array}$ & $\begin{array}{l}\text { Confirmada para o estrato } \\
\text { BT/FO - Médias empresas } \\
\text { Coeficiente estimado } \quad(\beta) \\
0,4342\end{array}$ \\
\hline H5.3 & $\begin{array}{l}\text { A cooperação com empresas de consultoria influencia } \\
\text { positivamente a apropriação de valor das inovações } \\
\text { geradas em arranjos cooperativos, pelos seus impactos } \\
\text { ambientais. }\end{array}$ & $\begin{array}{l}\text { Confirmada para o estrato } \\
\text { BT/FO - Grandes empresas } \\
\text { Coeficiente estimado } \quad(\beta) \\
0,7022\end{array}$ \\
\hline H6.3 & $\begin{array}{l}\text { A cooperação com universidades e institutos de pesquisa } \\
\text { influencia positivamente a apropriação de valor das } \\
\text { inovações geradas em arranjos cooperativos, pelos seus } \\
\text { impactos ambientais. }\end{array}$ & $\begin{array}{l}\text { Confirmada para o estrato } \\
\text { BT/FO - Médias empresas } \\
\text { Coeficiente estimado } \quad(\beta) \\
0,7102\end{array}$ \\
\hline H7.3 & $\begin{array}{l}\text { A cooperação com centros de capacitação profissional e } \\
\text { assistência técnica influencia positivamente a } \\
\text { apropriação de valor das inovações geradas em arranjos } \\
\text { cooperativos, pelos seus impactos ambientais }\end{array}$ & Não confirmada. \\
\hline H8.3 & $\begin{array}{l}\text { A cooperação com instituições de ensaios e certificações } \\
\text { influencia positivamente a apropriação de valor das } \\
\text { inovações geradas em arranjos cooperativos, pelos seus } \\
\text { impactos ambientais. }\end{array}$ & $\begin{array}{l}\text { Confirmada para o estrato } \\
\text { BT/FO - Médias empresas } \\
\text { Coeficiente estimado } \quad(\beta) \\
0,4815\end{array}$ \\
\hline
\end{tabular}

\subsubsection{4}

\section{Modelos estimados $Y_{\text {socl }}$}

A tabela 4.26 reúne os resultados obtidos dos coeficientes de regressão em relação aos modelos estimados $Y_{\text {soc }}$ para micro e pequenas, médias e grandes empresas de transformação que implementaram inovações com cooperação interorganizacional em um ambiente setorial de baixa tecnologia (BT) e com regime de apropriabilidade forte (FO).

Para o extrato - 'BT/FO - Grandes empresas', não foi possível estimar o modelo de regressão $Y_{S O C I}$ pelos resultados iniciais da aplicação do procedimento Stepwise, que indicaram que nenhum efeito (adicional) pela entrada das variáveis explanatórias no referido modelo atenderia ao nível de significância de 5\%. 
Tabela 4.26 - Resultados das regressões logísticas para os modelos estimados YsocI referentes aos estratos $\mathrm{BT} / \mathrm{FO}$

\begin{tabular}{|c|c|c|c|c|}
\hline \multicolumn{5}{|c|}{ Modelos estimados $Y_{\text {socl }}$ referentes aos estratos BT/FO } \\
\hline Parâmetro & $\begin{array}{l}\text { Coeficiente } \\
\text { estimado }(\beta)\end{array}$ & $\begin{array}{l}\text { Erro } \\
\text { padrão }(\varepsilon)\end{array}$ & $\begin{array}{l}\text { Wald } \\
\text { Qui quadrado }\end{array}$ & $\begin{array}{l}\text { Significância } \\
\left(\operatorname{Pr}>X^{2}\right)\end{array}$ \\
\hline \multicolumn{5}{|c|}{ Estrato BT/FO - Micro e pequenas empresas } \\
\hline Intercepto & 47,607 & 14,906 & 102,011 & 0,0014 \\
\hline \multicolumn{5}{|l|}{ Variável explanatória } \\
\hline$X_{\text {CLIE }}$ & 0,6282 & 0,2198 & 81,721 & $0,0043^{* *}$ \\
\hline$X_{\text {CONS }}$ & 0,7297 & 0,3721 & 38,442 & $0,0499^{*}$ \\
\hline $\begin{array}{l}\text { Qualidade de ajuste do } \\
\text { modelo }\end{array}$ & & & Qui quadrado & $\begin{array}{l}\text { Significância } \\
\left(\operatorname{Pr}>X^{2}\right)\end{array}$ \\
\hline $\begin{array}{l}\text { Capacidade preditiva } \\
\text { (Índice c) }\end{array}$ & 0,755 & & & \\
\hline Razão de verossimilhança & & & 162,217 & $0,0003^{* * *}$ \\
\hline $\begin{array}{l}\text { Log-verossimilhança } \\
\text { (modelo nulo) }\end{array}$ & 82,565 & & & \\
\hline $\begin{array}{l}\text { Log-verossimilhança } \\
\text { (modelo estimado) }\end{array}$ & 66,343 & & & \\
\hline $\begin{array}{l}\text { Teste de Hosmer- } \\
\text { Lemeshow }\end{array}$ & & & 48,138 & 0,4390 \\
\hline Número de casos & 66 & & & \\
\hline \multicolumn{5}{|c|}{ Estrato BT/FO - Médias empresas } \\
\hline Intercepto & 15,215 & 0,6450 & 55,641 & 0,0183 \\
\hline \multicolumn{5}{|l|}{ Variável explanatória } \\
\hline$X_{C C A P}$ & 0,3933 & 0,1848 & 45,288 & $0,0333^{*}$ \\
\hline $\begin{array}{l}\text { Qualidade de ajuste do } \\
\text { modelo }\end{array}$ & & & Qui quadrado & $\begin{array}{l}\text { Significância } \\
\left(\operatorname{Pr}>X^{2}\right)\end{array}$ \\
\hline $\begin{array}{l}\text { Capacidade preditiva } \\
\text { (Índice c) }\end{array}$ & 0,595 & & & \\
\hline Razão de verossimilhança & & & 49,119 & $0,0267^{*}$ \\
\hline $\begin{array}{l}\text { Log-verossimilhança } \\
\text { (modelo nulo) }\end{array}$ & 149,552 & & & \\
\hline $\begin{array}{l}\text { Log-verossimilhança } \\
\text { (modelo estimado) }\end{array}$ & 144,640 & & & \\
\hline $\begin{array}{l}\text { Teste de Hosmer- } \\
\text { Lemeshow }\end{array}$ & & & 14,393 & 0,4869 \\
\hline Número de casos & 109 & & & \\
\hline \multicolumn{5}{|c|}{ Estrato BT/FO - Grandes empresas } \\
\hline Intercepto & 0,6217 & 0,2302 & 72,922 & 0,0069 \\
\hline \multicolumn{5}{|l|}{ Variável explanatória } \\
\hline \multicolumn{5}{|c|}{$\begin{array}{l}\text { Nenhum efeito (adicional) pela entrada das variáveis explanatórias no modelo atendeu ao nível de } \\
\text { significância de } 5 \% \text {. }\end{array}$} \\
\hline $\begin{array}{l}\text { Qualidade de ajuste do } \\
\text { modelo }\end{array}$ & & & Qui quadrado & $\begin{array}{l}\text { Significância } \\
\left(\operatorname{Pr}>X^{2}\right)\end{array}$ \\
\hline $\begin{array}{l}\text { Capacidade preditiva } \\
\text { (Índice c) }\end{array}$ & - & & & \\
\hline Razão de verossimilhança & - & & & - \\
\hline $\begin{array}{l}\text { Log-verossimilhança } \\
\text { (modelo nulo) }\end{array}$ & 107,414 & & & \\
\hline $\begin{array}{l}\text { Log-verossimilhança } \\
\text { (modelo estimado) }\end{array}$ & - & & & \\
\hline $\begin{array}{l}\text { Teste de Hosmer- } \\
\text { Lemeshow }\end{array}$ & - & & & - \\
\hline Número de casos & 83 & & & \\
\hline
\end{tabular}


$\mathrm{Na}$ sequência, procedeu-se à análise dos resultados apresentados na tabela 4.26, visando testar as hipóteses de pesquisa relativas aos modelos estimados $Y_{S O C I}$ para os estratos BT/FO. Confirmaram-se as hipóteses H1.4; H5.4; e H7.4, confome quadro 4.20 .

Quadro 4.20 - Resultados das hipóteses de pesquisa dos modelos $Y_{S O C I}$ referentes aos estratos BT/FO

\begin{tabular}{|c|c|c|}
\hline Hipótese & Descrição & Resultado \\
\hline H1.4 & $\begin{array}{l}\text { A cooperação com clientes e consumidores influencia } \\
\text { positivamente a apropriação de valor das inovações } \\
\text { geradas em arranjos cooperativos, pelos seus impactos } \\
\text { sociais. }\end{array}$ & $\begin{array}{l}\text { Confirmada para o estrato } \\
\text { BT/FO - Micro e pequenas } \\
\text { Coeficiente estimado } \quad(\beta)= \\
0,6282\end{array}$ \\
\hline $\mathrm{H} 2.4$ & $\begin{array}{l}\text { A cooperação com fornecedores influencia positivamente } \\
\text { a apropriação de valor das inovações geradas em } \\
\text { arranjos cooperativos, pelos seus impactos sociais. }\end{array}$ & Não confirmada. \\
\hline H3.4 & $\begin{array}{l}\text { A cooperação com concorrentes influencia } \\
\text { positivamente a apropriação de valor das inovações } \\
\text { geradas em arranjos cooperativos, pelos seus impactos } \\
\text { sociais. }\end{array}$ & Não confirmada. \\
\hline H4.4 & $\begin{array}{l}\text { A cooperação com outra empresa do grupo influencia } \\
\text { positivamente a apropriação de valor das inovações } \\
\text { geradas em arranjos cooperativos, pelos seus impactos } \\
\text { sociais. }\end{array}$ & Não confirmada. \\
\hline H5.4 & $\begin{array}{l}\text { A cooperação com empresas de consultoria influencia } \\
\text { positivamente a apropriação de valor das inovações } \\
\text { geradas em arranjos cooperativos, pelos seus impactos } \\
\text { sociais. }\end{array}$ & $\begin{array}{l}\text { Confirmada para o estrato } \\
\text { BT/FO - Micro e pequenas } \\
\text { Coeficiente estimado } \quad(\beta) \\
0,7297\end{array}$ \\
\hline H6.4 & $\begin{array}{l}\text { A cooperação com universidades e institutos de pesquisa } \\
\text { influencia positivamente a apropriação de valor das } \\
\text { inovações geradas em arranjos cooperativos, pelos seus } \\
\text { impactos sociais. }\end{array}$ & Não confirmada. \\
\hline H7.4 & $\begin{array}{l}\text { A cooperação com centros de capacitação profissional e } \\
\text { assistência técnica influencia positivamente a } \\
\text { apropriação de valor das inovações geradas em arranjos } \\
\text { cooperativos, pelos seus impactos socais. }\end{array}$ & $\begin{array}{l}\text { Confirmada para o estrato } \\
\text { BT/FO - Médias empresas } \\
\text { Coeficiente estimado } \quad(\beta) \\
0,3933\end{array}$ \\
\hline H8.4 & $\begin{array}{l}\text { A cooperação com instituições de ensaios e certificações } \\
\text { influencia positivamente a apropriação de valor das } \\
\text { inovações geradas em arranjos cooperativos, pelos seus } \\
\text { impactos sociais. }\end{array}$ & Não confirmada. \\
\hline
\end{tabular}

Fonte: Elaboração própria.

\subsubsection{5}

\section{Modelos estimados $Y_{R E G U}$}

A tabela 4.27 reúne os resultados obtidos dos coeficientes de regressão em relação aos modelos estimados $Y_{R E G U}$ para micro e pequenas, médias e grandes empresas de transformação que implementaram inovações com cooperação interorganizacional em um ambiente setorial de baixa tecnologia (BT) e com regime de apropriabilidade forte (FO).

Com referência ao extrato - 'BT/FO - Micro e pequenas empresas', não foi possível estimar o modelo de regressão $Y_{R E G U}$ pelos resultados iniciais da aplicação do procedimento Stepwise, que indicaram que nenhum efeito (adicional) 
pela entrada das variáveis explanatórias no referido modelo atenderia ao nível de significância de 5\%.

Tabela 4.27 - Resultados das regressões logísticas para os modelos estimados $Y_{R E G U}$ referentes aos estratos BT/FO

\begin{tabular}{|c|c|c|c|c|}
\hline \multicolumn{5}{|c|}{ Modelos estimados $Y_{R E G U}$ referentes aos estratos BT/FO } \\
\hline Parâmetro & $\begin{array}{l}\text { Coeficiente } \\
\text { estimado }(\beta)\end{array}$ & $\begin{array}{l}\text { Erro } \\
\text { padrão }(\varepsilon)\end{array}$ & $\begin{array}{l}\text { Wald } \\
\text { Qui quadrado }\end{array}$ & $\begin{array}{l}\text { Significância } \\
\left(\operatorname{Pr}>X^{2}\right)\end{array}$ \\
\hline \multicolumn{5}{|c|}{ Estrato BT/FO - Micro e pequenas empresas } \\
\hline Intercepto & 0,6931 & 0,2611 & 70,466 & 0,0079 \\
\hline \multicolumn{5}{|c|}{ Variável explanatória } \\
\hline \multicolumn{5}{|c|}{$\begin{array}{l}\text { Nenhum efeito (adicional) pela entrada das variáveis explanatórias no modelo atendeu ao nível de } \\
\text { significância de } 5 \% \text {. }\end{array}$} \\
\hline $\begin{array}{l}\text { Qualidade de ajuste do } \\
\text { modelo }\end{array}$ & & & Qui quadrado & $\begin{array}{l}\text { Significância } \\
\left(\operatorname{Pr}>X^{2}\right)\end{array}$ \\
\hline $\begin{array}{l}\text { Capacidade preditiva } \\
\text { (Índice c) }\end{array}$ & - & & & \\
\hline Razão de verossimilhança & & & - & - \\
\hline $\begin{array}{l}\text { Log-verossimilhança } \\
\text { (modelo nulo) }\end{array}$ & 84,020 & & & \\
\hline $\begin{array}{l}\text { Log-verossimilhança } \\
\text { (modelo estimado) }\end{array}$ & - & & & \\
\hline $\begin{array}{l}\text { Teste de Hosmer- } \\
\text { Lemeshow }\end{array}$ & & & - & - \\
\hline Número de casos & 66 & & & \\
\hline \multicolumn{5}{|c|}{ Estrato BT/FO - Médias empresas } \\
\hline Intercepto & 0,8503 & 0,3768 & 50,929 & 0,0240 \\
\hline \multicolumn{5}{|l|}{ Variável explanatória } \\
\hline$X_{C L I E}$ & 0,3712 & 0,1586 & 54,749 & $0,0193^{*}$ \\
\hline $\begin{array}{l}\text { Qualidade de ajuste do } \\
\text { modelo }\end{array}$ & & & Qui quadrado & $\begin{array}{l}\text { Significância } \\
\left(\operatorname{Pr}>X^{2}\right)\end{array}$ \\
\hline $\begin{array}{l}\text { Capacidade preditiva } \\
\text { (Índice c) }\end{array}$ & 0,618 & & & \\
\hline Razão de verossimilhança & & & 57,183 & $0,0168^{*}$ \\
\hline $\begin{array}{l}\text { Log-verossimilhança } \\
\text { (modelo nulo) }\end{array}$ & 150,877 & & & \\
\hline $\begin{array}{l}\text { Log-verossimilhança } \\
\text { (modelo estimado) }\end{array}$ & 145,158 & & & \\
\hline $\begin{array}{l}\text { Teste de Hosmer- } \\
\text { Lemeshow }\end{array}$ & & & 0,0378 & 0,9813 \\
\hline Número de casos & 109 & & & \\
\hline \multicolumn{5}{|c|}{ Estrato BT/FO - Grandes empresas } \\
\hline Intercepto & 12,676 & 0,5898 & 46,195 & 0,0316 \\
\hline \multicolumn{5}{|l|}{ Variável explanatória } \\
\hline$X_{E M P R}$ & 0,4030 & 0,1890 & 45,467 & $0,0330^{*}$ \\
\hline $\begin{array}{l}\text { Qualidade de ajuste do } \\
\text { modelo }\end{array}$ & & & Qui quadrado & $\begin{array}{l}\text { Significância } \\
\left(\operatorname{Pr}>X^{2}\right)\end{array}$ \\
\hline $\begin{array}{l}\text { Capacidade preditiva } \\
\text { (Índice c) }\end{array}$ & 0,624 & & & \\
\hline Razão de verossimilhança & & & 47,750 & $0,0289^{*}$ \\
\hline $\begin{array}{l}\text { Log-verossimilhança } \\
\text { (modelo nulo) }\end{array}$ & 114,761 & & & \\
\hline $\begin{array}{l}\text { Log-verossimilhança } \\
\text { (modelo estimado) }\end{array}$ & 109,986 & & & \\
\hline $\begin{array}{l}\text { Teste de Hosmer- } \\
\text { Lemeshow }\end{array}$ & & & 16,731 & 0,4332 \\
\hline Número de casos & 83 & & & \\
\hline
\end{tabular}


A análise dos resultados apresentados na tabela 4.27, visando testar as hipóteses de pesquisa relativas aos modelos estimados $Y_{R E G U}$ para os estratos BT/FO permitiu a confirmação das hipóteses H1.5 e H4.5, conforme quadro 4.21.

Quadro 4.21- Resultados das hipóteses de pesquisa dos modelos $Y_{R E G U}$ referentes aos estratos BT/FO

\begin{tabular}{|c|c|c|}
\hline Hipótese & Descrição & Resultado \\
\hline H1.5 & $\begin{array}{l}\text { A cooperação com clientes e consumidores influencia } \\
\text { positivamente a apropriação de valor das inovações } \\
\text { geradas em arranjos cooperativos, pelos seus impactos } \\
\text { regulatórios. }\end{array}$ & $\begin{array}{l}\text { Confirmada para o estrato } \\
\text { BT/FO - Médias empresas } \\
\text { Coeficiente estimado } \quad(\beta)= \\
0,3712\end{array}$ \\
\hline H2.5 & $\begin{array}{l}\text { A cooperação com fornecedores influencia positivamente } \\
\text { a apropriação de valor das inovações geradas em } \\
\text { arranjos cooperativos, pelos seus impactos regulatórios. }\end{array}$ & Não confirmada. \\
\hline H3.5 & $\begin{array}{l}\text { A cooperação com concorrentes influencia } \\
\text { positivamente a apropriação de valor das inovações } \\
\text { geradas em arranjos cooperativos, pelos seus impactos } \\
\text { regulatórios. }\end{array}$ & Não confirmada. \\
\hline H4.5 & $\begin{array}{l}\text { A cooperação com outra empresa do grupo influencia } \\
\text { positivamente a apropriação de valor das inovações } \\
\text { geradas em arranjos cooperativos, pelos seus impactos } \\
\text { regulatórios. }\end{array}$ & $\begin{array}{l}\text { Confirmada para o estrato } \\
\text { BT/FO - Grandes empresas } \\
\text { Coeficiente estimado } \quad(\beta)= \\
0,4030\end{array}$ \\
\hline H5.5 & $\begin{array}{l}\text { A cooperação com empresas de consultoria influencia } \\
\text { positivamente a apropriação de valor das inovações } \\
\text { geradas em arranjos cooperativos, pelos seus impactos } \\
\text { regulatórios. }\end{array}$ & Não confirmada. \\
\hline H6.5 & $\begin{array}{l}\text { A cooperação com universidades e institutos de pesquisa } \\
\text { influencia positivamente a apropriação de valor das } \\
\text { inovações geradas em arranjos cooperativos, pelos seus } \\
\text { impactos regulatórios. }\end{array}$ & Não confirmada. \\
\hline H7.5 & $\begin{array}{l}\text { A cooperação com centros de capacitação profissional e } \\
\text { assistência técnica influencia positivamente a } \\
\text { apropriação de valor das inovações geradas em arranjos } \\
\text { cooperativos, pelos seus impactos regulatórios. }\end{array}$ & Não confirmada. \\
\hline H8.5 & $\begin{array}{l}\text { A cooperação com instituições de ensaios e certificações } \\
\text { influencia positivamente a apropriação de valor das } \\
\text { inovações geradas em arranjos cooperativos, pelos seus } \\
\text { impactos regulatórios. }\end{array}$ & Não confirmada. \\
\hline
\end{tabular}

Fonte: Elaboração própria.

\subsubsection{6}

\section{Discussão dos resultados do agrupamento setorial BT/FO}

As micro e pequenas empresas deste agrupamento formam parcerias preferencialmente com clientes e consumidores, visando melhorar seus processos de produção e as condições de saúde e segurança para seus colaboradores e/ou clientes. As empresas de consultoria como parceiros de escolha para essas empresas geram inovações com impactos sociais, ou seja, melhoria das condições de saúde e segurança para seus colaboradores e/ou clientes e/ou atendimento a regulamentos e normas aplicáveis.

As empresas de médio porte que atuam em setores de intensidade tecnológica baixa, mas com regime de apropriabilidade forte, buscam cooperação em seus projetos de PD\&I com diversos parceiros, a saber: (i) universidades e 
institutos de pesquisa; (ii) clientes e consumidores; (iii) concorrentes; (iv) centros de capacitação profissional; e (v) instituições de ensaios e certificações. As inovações visam preponderantemente atender à legislação ambiental; requisitos de normas de gestão ambiental aplicáveis; seguidas de inovações com impactos na produção e sociais.

Já as empresas de grande porte que atuam nesses setores (BT/FO) buscam cooperar em seus projetos de PD\&I preferencialmente com seus clientes e consumidores finais dos produtos que ofertam, criando inovações com impactos mercadológicos, ambientais e na produção. Outros parceiros importantes são as empresas de consultoria na introdução no mercado de inovações com impactos ambientais.

\subsection{4.}

Análise da influência dos parceiros em arranjos cooperativos sobre a apropriação de valor das inovações geradas: agrupamento setorial BT/FR

As tabelas 4.28 a 4.32, a seguir, apresentam as estimativas dos coeficientes de regressão em relação aos modelos logit para empresas do agrupamento setorial BT/FR da indústria de transformação no Brasil, que implementaram inovações em arranjos cooperativos com outras organizações no período de 2012 a 2014. Essas tabelas referem-se aos resultados deste agrupamento setorial, desagregados por tamanho das empresas em: (i) micro e pequenas; (ii) médias; e (iii) grandes.

\subsubsection{1}

\section{Modelos estimados $Y_{M E R C}$}

A tabela 4.28 reúne os resultados obtidos dos coeficientes de regressão em relação aos modelos estimados $Y_{M E R C}$ para micro e pequenas, médias e grandes empresas de transformação que implementaram inovações com cooperação interorganizacional em um ambiente setorial de baixa tecnologia (BT) e com regime de apropriabilidade fraco (FR).

Somente com relação ao extrato - 'BT/FR - Médias empresas', não foi possível estimar o modelo de regressão $Y_{M E R C}$ pelos resultados iniciais da aplicação do procedimento Stepwise, que indicaram que nenhum efeito (adicional) pela entrada das variáveis explanatórias no referido modelo atenderia ao nível de significância de 5\%. 
Tabela 4.28 - Resultados das regressões logísticas para os modelos estimados YMERC referentes aos estratos BT/FR

\begin{tabular}{|c|c|c|c|c|}
\hline \multicolumn{5}{|c|}{ Modelos estimados $Y_{M E R C}$ referentes aos estratos BT/FR } \\
\hline Parâmetro & $\begin{array}{l}\text { Coeficiente } \\
\text { estimado }(\beta)\end{array}$ & $\begin{array}{l}\text { Erro } \\
\text { padrão }(\varepsilon)\end{array}$ & $\begin{array}{l}\text { Wald } \\
\text { Qui quadrado }\end{array}$ & $\begin{array}{l}\text { Significância } \\
\left(\operatorname{Pr}>X^{2}\right)\end{array}$ \\
\hline \multicolumn{5}{|c|}{ Estrato BT/FR - Micro e pequenas empresas } \\
\hline Intercepto & 28,138 & 0,8746 & 103,505 & 0,0013 \\
\hline \multicolumn{5}{|l|}{ Variável explanatória } \\
\hline$X_{I C T S}$ & 0,5059 & 0,2343 & 46,643 & $0,0308^{*}$ \\
\hline $\begin{array}{l}\text { Qualidade de ajuste do } \\
\text { modelo }\end{array}$ & & & Qui quadrado & $\begin{array}{l}\text { Significância } \\
\left(\mathrm{Pr}>\mathrm{X}^{2}\right)\end{array}$ \\
\hline $\begin{array}{l}\text { Capacidade preditiva } \\
\text { (Índice c) }\end{array}$ & 0,588 & & & \\
\hline Razão de verossimilhança & & & 59,278 & $0,0149^{*}$ \\
\hline $\begin{array}{l}\text { Log-verossimilhança } \\
\text { (modelo nulo) }\end{array}$ & 179,708 & & & \\
\hline $\begin{array}{l}\text { Log-verossimilhança } \\
\text { (modelo estimado) }\end{array}$ & 173,780 & & & \\
\hline $\begin{array}{l}\text { Teste de Hosmer- } \\
\text { Lemeshow }\end{array}$ & & & 0,9802 & 0,6126 \\
\hline Número de casos & 156 & & & \\
\hline \multicolumn{5}{|c|}{ Estrato BT/FR - Médias empresas } \\
\hline Intercepto & 14,153 & 0,1561 & 821,930 & $<0,0001^{* \star *}$ \\
\hline \multicolumn{5}{|l|}{ Variável explanatória } \\
\hline \multicolumn{5}{|c|}{$\begin{array}{l}\text { Nenhum efeito (adicional) pela entrada das variáveis explanatórias no modelo atendeu ao nível de } \\
\text { significância de } 5 \% \text {. }\end{array}$} \\
\hline $\begin{array}{l}\text { Qualidade de ajuste do } \\
\text { modelo }\end{array}$ & & & Qui quadrado & $\begin{array}{l}\text { Significância } \\
\left(\operatorname{Pr}>X^{2}\right)\end{array}$ \\
\hline $\begin{array}{l}\text { Capacidade preditiva } \\
\text { (Índice c) }\end{array}$ & - & & & \\
\hline Razão de verossimilhança & & & - & - \\
\hline $\begin{array}{l}\text { Log-verossimilhança } \\
\text { (modelo nulo) }\end{array}$ & 257,848 & & & \\
\hline $\begin{array}{l}\text { Log-verossimilhança } \\
\text { (modelo estimado) }\end{array}$ & - & & & \\
\hline $\begin{array}{l}\text { Teste de Hosmer- } \\
\text { Lemeshow }\end{array}$ & & & - & - \\
\hline Número de casos & 261 & & & \\
\hline \multicolumn{5}{|c|}{ Estrato BT/FR - Grandes empresas } \\
\hline Intercepto & 25,241 & 0,4707 & 287,513 & $<0,0001^{* * *}$ \\
\hline \multicolumn{5}{|l|}{ Variável explanatória } \\
\hline$X_{C L I E}$ & 0,3744 & 0,1501 & 62,263 & $0,0126^{*}$ \\
\hline $\begin{array}{l}\text { Qualidade de ajuste do } \\
\text { modelo }\end{array}$ & & & Qui quadrado & $\begin{array}{l}\text { Significância } \\
\left(\operatorname{Pr}>X^{2}\right)\end{array}$ \\
\hline $\begin{array}{l}\text { Capacidade preditiva } \\
\text { (Índice c) }\end{array}$ & 0,629 & & & \\
\hline Razão de verossimilhança & & & 65,805 & $0,0103^{*}$ \\
\hline $\begin{array}{l}\text { Log-verossimilhança } \\
\text { (modelo nulo) }\end{array}$ & 178,915 & & & \\
\hline $\begin{array}{l}\text { Log-verossimilhança } \\
\text { (modelo estimado) }\end{array}$ & 172,334 & & & \\
\hline $\begin{array}{l}\text { Teste de Hosmer- } \\
\text { Lemeshow }\end{array}$ & & & 0,1001 & 0,9512 \\
\hline Número de casos & 191 & & & \\
\hline
\end{tabular}

Com o objetivo de testar as hipóteses de pesquisa relativas aos modelos estimados $Y_{M E R C}$ para estratos referentes aos estratos $\mathrm{BT} / \mathrm{FR}$, procedeu-se à 
análise dos resultados apresentados na tabela 4.28. Confirmaram-se as hipóteses H1.1 e H6.1, como mostra o quadro 4.22, a seguir.

Quadro 4.22 - Resultados das hipóteses de pesquisa dos modelos $Y_{M E R C}$ referentes aos estratos BT/FR

\begin{tabular}{|c|c|c|}
\hline Hipótese & Descrição & Resultado \\
\hline H1.1 & $\begin{array}{l}\text { A cooperação com clientes e consumidores influencia } \\
\text { positivamente a apropriação de valor das inovações } \\
\text { geradas em arranjos cooperativos, pelos seus } \\
\text { impactos mercadológicos. }\end{array}$ & $\begin{array}{l}\text { Confirmada para o estrato } \\
\text { BT/FR - Grandes empresas } \\
\text { Coeficiente estimado }(\beta)=0,3744\end{array}$ \\
\hline H2.1 & $\begin{array}{l}\text { A cooperação com fornecedores influencia } \\
\text { positivamente a apropriação de valor das inovações } \\
\text { geradas em arranjos cooperativos, pelos seus } \\
\text { impactos mercadológicos. }\end{array}$ & Não confirmada. \\
\hline H3.1 & $\begin{array}{l}\text { A cooperação com concorrentes influencia } \\
\text { positivamente a apropriação de valor das inovações } \\
\text { geradas em arranjos cooperativos, pelos seus } \\
\text { impactos mercadológicos. }\end{array}$ & Não confirmada. \\
\hline H4.1 & $\begin{array}{l}\text { A cooperação com outra empresa do grupo influencia } \\
\text { positivamente a apropriação de valor das inovações } \\
\text { geradas em arranjos cooperativos, pelos seus } \\
\text { impactos mercadológicos. }\end{array}$ & Não confirmada. \\
\hline H5.1 & $\begin{array}{l}\text { A cooperação com empresas de consultoria } \\
\text { influencia positivamente a apropriação de valor das } \\
\text { inovações geradas em arranjos cooperativos, pelos } \\
\text { seus impactos mercadológicos. }\end{array}$ & Não confirmada. \\
\hline H6.1 & $\begin{array}{l}\text { A cooperação com universidades e institutos de } \\
\text { pesquisa influencia positivamente a apropriação de } \\
\text { valor das inovações geradas em arranjos } \\
\text { cooperativos, pelos seus impactos mercadológicos. }\end{array}$ & $\begin{array}{l}\text { Confirmada para o estrato } \\
\text { BT/FR - Micro e pequenas empresas } \\
\text { Coeficiente estimado }(\beta)=0,5059\end{array}$ \\
\hline H7.1 & $\begin{array}{l}\text { A cooperação com centros de capacitação } \\
\text { profissional e assistência técnica influencia } \\
\text { positivamente a apropriação de valor das inovações } \\
\text { geradas em arranjos cooperativos, pelos seus } \\
\text { impactos mercadológicos. }\end{array}$ & Não confirmada. \\
\hline H8.1 & $\begin{array}{l}\text { A cooperação com instituições de ensaios e } \\
\text { certificações influencia positivamente a apropriação } \\
\text { de valor das inovações geradas em arranjos } \\
\text { cooperativos, pelos seus impactos mercadológicos. }\end{array}$ & Não confirmada. \\
\hline
\end{tabular}

Fonte: Elaboração própria.

\subsubsection{2}

\section{Modelos estimados YPROD}

A tabela 4.29 reúne os resultados obtidos dos coeficientes de regressão em relação aos modelos estimados $Y_{P R O D}$ para micro e pequenas, médias e grandes empresas de transformação que implementaram inovações com cooperação interorganizacional em um ambiente setorial de baixa tecnologia (BT) e com regime de apropriabilidade fraco (FR).

Pelos resultados iniciais da aplicação do procedimento Stepwise nos dados do extrato - 'BT/FR - Micro e pequenas empresas', constatou-se não ser possível estimar o modelo de regressão $Y_{P R O D}$, pois a entrada de nenhuma das variáveis explanatórias no referido modelo atenderia ao nível de significância de 5\% e contribuiria para a melhoria de sua capacidade preditiva. 
Tabela 4.29 - Resultados das regressões logísticas para os modelos estimados YPROD referentes aos estratos BT/FR

\begin{tabular}{|c|c|c|c|c|}
\hline \multicolumn{5}{|c|}{ Modelos estimados $Y_{P R O D}$ referentes aos estratos BT/FR } \\
\hline Parâmetro & $\begin{array}{l}\text { Coeficiente } \\
\text { estimado }(\beta)\end{array}$ & $\begin{array}{l}\text { Erro } \\
\text { padrão }(\varepsilon)\end{array}$ & $\begin{array}{l}\text { Wald } \\
\text { Qui quadrado }\end{array}$ & $\begin{array}{l}\text { Significância } \\
\left(\operatorname{Pr}>X^{2}\right)\end{array}$ \\
\hline \multicolumn{5}{|c|}{ Estrato BT/FR - Micro e pequenas empresas } \\
\hline Intercepto & 0,4700 & 0,1646 & 81,564 & 0,0043 \\
\hline \multicolumn{5}{|l|}{ Variável explanatória } \\
\hline \multicolumn{5}{|c|}{$\begin{array}{l}\text { Nenhum efeito (adicional) pela entrada das variáveis explanatórias no modelo atendeu ao nível de } \\
\text { significância de } 5 \% \text {. }\end{array}$} \\
\hline $\begin{array}{l}\text { Qualidade de ajuste do } \\
\text { modelo }\end{array}$ & & & Qui quadrado & $\begin{array}{l}\text { Significância } \\
\left(\operatorname{Pr}>X^{2}\right)\end{array}$ \\
\hline $\begin{array}{l}\text { Capacidade preditiva } \\
\text { (Índice c) }\end{array}$ & - & & & \\
\hline Razão de verossimilhança & - & & & - \\
\hline $\begin{array}{l}\text { Log-verossimilhança } \\
\text { (modelo nulo) }\end{array}$ & 207,879 & & & \\
\hline $\begin{array}{l}\text { Log-verossimilhança } \\
\text { (modelo estimado) }\end{array}$ & - & & & \\
\hline $\begin{array}{l}\text { Teste de Hosmer- } \\
\text { Lemeshow }\end{array}$ & - & & & - \\
\hline Número de casos & 156 & & & \\
\hline \multicolumn{5}{|c|}{ Estrato BT/FR - Médias empresas } \\
\hline Intercepto & 22,900 & 0,5410 & 179,195 & $<0,0001^{* * *}$ \\
\hline \multicolumn{5}{|l|}{ Variável explanatória } \\
\hline$X_{\text {CONC }}$ & 0,2746 & 0,1300 & 44,611 & $0,0347^{*}$ \\
\hline$X_{\text {CONS }}$ & 0,3732 & 0,1181 & 99,876 & $0,0016^{\star \star}$ \\
\hline $\begin{array}{l}\text { Qualidade de ajuste do } \\
\text { modelo }\end{array}$ & & & Qui quadrado & $\begin{array}{l}\text { Significância } \\
\left(\operatorname{Pr}>X^{2}\right)\end{array}$ \\
\hline $\begin{array}{l}\text { Capacidade preditiva } \\
\text { (Índice c) }\end{array}$ & 0,646 & & & \\
\hline Razão de verossimilhança & & & 180,481 & $0,0001^{* *}$ \\
\hline $\begin{array}{l}\text { Log-verossimilhança } \\
\text { (modelo nulo) }\end{array}$ & 357,639 & & & \\
\hline $\begin{array}{l}\text { Log-verossimilhança } \\
\text { (modelo estimado) }\end{array}$ & 339,591 & & & \\
\hline $\begin{array}{l}\text { Teste de Hosmer- } \\
\text { Lemeshow }\end{array}$ & & & 45,745 & 0,4700 \\
\hline Número de casos & 261 & & & \\
\hline \multicolumn{5}{|c|}{ Estrato BT/FR - Grandes empresas } \\
\hline Parâmetro & $\begin{array}{l}\text { Coeficiente } \\
\text { estimado } \\
(\beta)\end{array}$ & $\begin{array}{l}\text { Erro padrão } \\
(\varepsilon)\end{array}$ & $\begin{array}{l}\text { Wald } \\
\text { Qui quadrado }\end{array}$ & $\begin{array}{l}\text { Significância } \\
\left(\operatorname{Pr}>X^{2}\right)\end{array}$ \\
\hline Intercepto & 10,633 & 0,3233 & 108,179 & $0,0010^{\star *}$ \\
\hline \multicolumn{5}{|l|}{ Variável explanatória } \\
\hline$X_{\text {CLIE }}$ & 0,2783 & 0,1132 & 60,434 & $0,0140^{*}$ \\
\hline $\begin{array}{l}\text { Qualidade de ajuste do } \\
\text { modelo }\end{array}$ & & & Qui quadrado & $\begin{array}{l}\text { Significância } \\
\left(\operatorname{Pr}>X^{2}\right)\end{array}$ \\
\hline $\begin{array}{l}\text { Capacidade preditiva } \\
\text { (Índice c) }\end{array}$ & 0,600 & & & \\
\hline Razão de verossimilhança & & & 61,653 & $0,0130^{*}$ \\
\hline $\begin{array}{l}\text { Log-verossimilhança } \\
\text { (modelo nulo) }\end{array}$ & 258,332 & & & \\
\hline $\begin{array}{l}\text { Log-verossimilhança } \\
\text { (modelo estimado) }\end{array}$ & 252,167 & & & \\
\hline $\begin{array}{l}\text { Teste de Hosmer- } \\
\text { Lemeshow }\end{array}$ & & & 57,969 & 0,0551 \\
\hline Número de casos & 191 & & & \\
\hline
\end{tabular}


Na sequência, procedeu-se a análise dos resultados apresentados na tabela 4.29 , visando testar as hipóteses de pesquisa relativas aos modelos estimados $Y_{P R O D}$ para estratos referentes aos estratos BT/FR. Confirmaram-se as hipóteses H1.2; H3.2; e H5.2, como mostrado no quadro 4.23 abaixo.

Quadro 4.23 - Resultados das hipóteses de pesquisa dos modelos $Y_{P R O D}$ referentes aos estratos BT/FR

\begin{tabular}{|c|c|c|}
\hline Hipótese & Descrição & Resultado \\
\hline H1.2 & $\begin{array}{l}\text { A cooperação com clientes e consumidores } \\
\text { influencia positivamente a apropriação de valor das } \\
\text { inovações geradas em arranjos cooperativos, pelos } \\
\text { seus impactos na produção. }\end{array}$ & $\begin{array}{l}\text { Confirmada para o estrato } \\
\text { BT/FR - Grandes empresas } \\
\text { Coeficiente estimado }(\beta)=0,2783\end{array}$ \\
\hline $\mathrm{H} 2.2$ & $\begin{array}{l}\text { A cooperação com fornecedores influencia } \\
\text { positivamente a apropriação de valor das inovações } \\
\text { geradas em arranjos cooperativos, pelos seus } \\
\text { impactos na produção. }\end{array}$ & Não confirmada \\
\hline H3.2 & $\begin{array}{l}\text { A cooperação com concorrentes influencia } \\
\text { positivamente a apropriação de valor das inovações } \\
\text { geradas em arranjos cooperativos, pelos seus } \\
\text { impactos na produção. }\end{array}$ & $\begin{array}{l}\text { Confirmada para o estrato } \\
\text { BT/FR - Médias empresas } \\
\text { Coeficiente estimado }(\beta)=0,2746\end{array}$ \\
\hline H4.2 & $\begin{array}{l}\text { A cooperação com outra empresa do grupo influencia } \\
\text { positivamente a apropriação de valor das inovações } \\
\text { geradas em arranjos cooperativos, pelos seus } \\
\text { impactos na produção. }\end{array}$ & \\
\hline H5.2 & $\begin{array}{l}\text { A cooperação com empresas de consultoria } \\
\text { influencia positivamente a apropriação de valor das } \\
\text { inovações geradas em arranjos cooperativos, pelos } \\
\text { seus impactos na produção. }\end{array}$ & $\begin{array}{l}\text { Confirmada para o estrato } \\
\text { BT/FR - Médias empresas } \\
\text { Coeficiente estimado }(\beta)=0,3732\end{array}$ \\
\hline H6.2 & $\begin{array}{l}\text { A cooperação com universidades e institutos de } \\
\text { pesquisa influencia positivamente a apropriação de } \\
\text { valor das inovações geradas em arranjos } \\
\text { cooperativos, pelos seus impactos na produção. }\end{array}$ & Não confirmada. \\
\hline H7.2 & $\begin{array}{l}\text { A cooperação com centros de capacitação } \\
\text { profissional e assistência técnica influencia } \\
\text { positivamente a apropriação de valor das inovações } \\
\text { geradas em arranjos cooperativos, pelos seus } \\
\text { impactos na produção. }\end{array}$ & Não confirmada. \\
\hline H8.2 & $\begin{array}{l}\text { A cooperação com instituições de ensaios e } \\
\text { certificações influencia positivamente a apropriação } \\
\text { de valor das inovações geradas em arranjos } \\
\text { cooperativos, pelos seus impactos na produção. }\end{array}$ & Não confirmada. \\
\hline
\end{tabular}

Fonte: Elaboração própria.

\subsubsection{3 \\ Modelos estimados $Y_{A M B I}$}

A tabela 4.30 reúne os resultados obtidos dos coeficientes de regressão em relação aos modelos estimados $Y_{A M B I}$ para micro e pequenas, médias e grandes empresas de transformação que implementaram inovações com cooperação interorganizacional em um ambiente setorial de baixa tecnologia (BT) e com regime de apropriabilidade fraco (FR). 
Tabela 4.30 - Resultados das regressões logísticas para os modelos estimados $Y_{A M B I}$ referentes aos estratos BT/FR

\begin{tabular}{|c|c|c|c|c|}
\hline \multicolumn{5}{|c|}{ Modelos estimados $Y_{A M B I}$ referentes aos estratos BT/FR } \\
\hline Parâmetro & $\begin{array}{l}\text { Coeficiente } \\
\text { estimado }(\beta)\end{array}$ & $\begin{array}{l}\text { Erro } \\
\text { padrão }(\varepsilon)\end{array}$ & $\begin{array}{l}\text { Wald } \\
\text { Qui quadrado }\end{array}$ & $\begin{array}{l}\text { Significância } \\
\left(\mathrm{Pr}>\mathrm{X}^{2}\right)\end{array}$ \\
\hline \multicolumn{5}{|c|}{ Estrato BT/FR - Micro e pequenas empresas } \\
\hline Intercepto & 0,3573 & 0,5411 & 0,4359 & 0,5091 \\
\hline \multicolumn{5}{|l|}{ Variável explanatória } \\
\hline$X_{C E R T}$ & 0,3789 & 0,1709 & 49,177 & $0,0266^{*}$ \\
\hline $\begin{array}{l}\text { Qualidade de ajuste do } \\
\text { modelo }\end{array}$ & & & Qui quadrado & $\begin{array}{l}\text { Significância } \\
\left(\mathrm{Pr}>\mathrm{X}^{2}\right)\end{array}$ \\
\hline $\begin{array}{l}\text { Capacidade preditiva } \\
\text { (Índice c) }\end{array}$ & 0,616 & & & \\
\hline Razão de verossimilhança & & & 47,729 & $0,0289^{*}$ \\
\hline $\begin{array}{l}\text { Log-verossimilhança } \\
\text { (modelo nulo) }\end{array}$ & 146,832 & & & \\
\hline $\begin{array}{l}\text { Log-verossimilhança } \\
\text { (modelo estimado) }\end{array}$ & 142,059 & & & \\
\hline $\begin{array}{l}\text { Teste de Hosmer- } \\
\text { Lemeshow }\end{array}$ & & & 0,0352 & 0,9826 \\
\hline Número de casos & 156 & & & \\
\hline \multicolumn{5}{|c|}{ Estrato BT/FR - Médias empresas } \\
\hline Intercepto & 0,4208 & 0.3304 & 16.223 & 0,2028 \\
\hline \multicolumn{5}{|l|}{ Variável explanatória } \\
\hline$X_{C E R T}$ & 0,2802 & 0,1162 & 58,185 & $0,0159^{*}$ \\
\hline $\begin{array}{l}\text { Qualidade de ajuste do } \\
\text { modelo }\end{array}$ & & & Qui quadrado & $\begin{array}{l}\text { Significância } \\
\left(\mathrm{Pr}>\mathrm{X}^{2}\right)\end{array}$ \\
\hline $\begin{array}{l}\text { Capacidade preditiva } \\
\text { (Índice c) }\end{array}$ & 0,596 & & & \\
\hline Razão de verossimilhança & & & 58,793 & $0,0153^{*}$ \\
\hline $\begin{array}{l}\text { Log-verossimilhança } \\
\text { (modelo nulo) }\end{array}$ & 286,180 & & & \\
\hline $\begin{array}{l}\text { Log-verossimilhança } \\
\text { (modelo estimado) }\end{array}$ & 280,300 & & & \\
\hline $\begin{array}{l}\text { Teste de Hosmer- } \\
\text { Lemeshow }\end{array}$ & & & 0,4474 & 0,7995 \\
\hline Número de casos & 261 & & & \\
\hline \multicolumn{5}{|c|}{ Estrato BT/FR - Grandes empresas } \\
\hline Intercepto & 0,3860 & 0,3875 & 0,9922 & 0,3192 \\
\hline \multicolumn{5}{|l|}{ Variável explanatória } \\
\hline$X_{C E R T}$ & 0,4001 & 0,1305 & 93,950 & $0,0022^{\star *}$ \\
\hline $\begin{array}{l}\text { Qualidade de ajuste do } \\
\text { modelo }\end{array}$ & & & Qui quadrado & $\begin{array}{l}\text { Significância } \\
\left(\operatorname{Pr}>X^{2}\right)\end{array}$ \\
\hline $\begin{array}{l}\text { Capacidade preditiva } \\
\text { (Índice c) }\end{array}$ & 0,630 & & & \\
\hline Razão de verossimilhança & & & 96,341 & $0,0019^{* *}$ \\
\hline $\begin{array}{l}\begin{array}{l}\text { Log-verossimilhança } \\
\text { (modelo nulo) }\end{array} \\
\end{array}$ & 240,772 & & & \\
\hline $\begin{array}{l}\text { Log-verossimilhança } \\
\text { (modelo estimado) }\end{array}$ & 231,138 & & & \\
\hline $\begin{array}{l}\text { Teste de Hosmer- } \\
\text { Lemeshow }\end{array}$ & & & 33,432 & 0,1879 \\
\hline Número de casos & 191 & & & \\
\hline
\end{tabular}

Na sequência, procedeu-se a análise dos resultados apresentados na tabela 4.30 para testar as hipóteses de pesquisa relativas aos modelos estimados 
$Y_{A M B I}$ para os três estratos do agrupamento setorial BT/FR. Como mostra o quadro 4.24, a hipótese H8.3 foi confirmada para os três estratos de ste agrupamento setorial.

Quadro 4.24 - Resultados das hipóteses de pesquisa dos modelos $Y_{A M B I}$ referentes aos estratos BT/FR

\begin{tabular}{|c|c|c|}
\hline Hipótese & Descrição & Resultado \\
\hline H1.3 & $\begin{array}{l}\text { A cooperação com clientes e consumidores } \\
\text { influencia positivamente a apropriação de valor das } \\
\text { inovações geradas em arranjos cooperativos, pelos } \\
\text { seus impactos ambientais. }\end{array}$ & Não confirmada. \\
\hline H2.3 & $\begin{array}{l}\text { A cooperação com fornecedores influencia } \\
\text { positivamente a apropriação de valor das inovações } \\
\text { geradas em arranjos cooperativos, pelos seus } \\
\text { impactos ambientais. }\end{array}$ & Não confirmada. \\
\hline H3.3 & $\begin{array}{l}\text { A cooperação com concorrentes influencia } \\
\text { positivamente a apropriação de valor das inovações } \\
\text { geradas em arranjos cooperativos, pelos seus } \\
\text { impactos ambientais. }\end{array}$ & Não confirmada. \\
\hline H4.3 & $\begin{array}{l}\text { A cooperação com outra empresa do grupo influencia } \\
\text { positivamente a apropriação de valor das inovações } \\
\text { geradas em arranjos cooperativos, pelos seus } \\
\text { impactos ambientais. }\end{array}$ & Não confirmada. \\
\hline H5.3 & $\begin{array}{l}\text { A cooperação com empresas de consultoria } \\
\text { influencia positivamente a apropriação de valor das } \\
\text { inovações geradas em arranjos cooperativos, pelos } \\
\text { seus impactos ambientais. }\end{array}$ & Não confirmada. \\
\hline H6.3 & $\begin{array}{l}\text { A cooperação com universidades e institutos de } \\
\text { pesquisa influencia positivamente a apropriação de } \\
\text { valor das inovações geradas em arranjos } \\
\text { cooperativos, pelos seus impactos ambientais. }\end{array}$ & Não confirmada. \\
\hline H7.3 & $\begin{array}{l}\text { A cooperação com centros de capacitação } \\
\text { profissional e assistência técnica influencia } \\
\text { positivamente a apropriação de valor das inovações } \\
\text { geradas em arranjos cooperativos, pelos seus } \\
\text { impactos ambientais }\end{array}$ & Não confirmada. \\
\hline H8.3 & $\begin{array}{l}\text { A cooperação com instituições de ensaios e } \\
\text { certificações influencia positivamente a apropriação } \\
\text { de valor das inovações geradas em arranjos } \\
\text { cooperativos, pelos seus impactos ambientais. }\end{array}$ & $\begin{array}{l}\text { Confirmada para os três estratos } \\
\text { BT/FR - Micro e pequenas empresas } \\
\text { Coeficiente estimado }(\beta)=0,3789 \\
\text { BT/FR - Médias empresas } \\
\text { Coeficiente estimado }(\beta)=0,2802 \\
\text { BT/FR - Grandes empresas } \\
\text { Coeficiente estimado }(\beta)=0,4001\end{array}$ \\
\hline
\end{tabular}

Fonte: Elaboração própria.

\subsubsection{4}

\section{Modelos estimados $Y_{\text {socl }}$}

A tabela 4.31 reúne os resultados obtidos dos coeficientes de regressão em relação aos modelos estimados $Y_{\text {Soc }}$ para micro e pequenas, médias e grandes empresas de transformação que implementaram inovações com cooperação interorganizacional em um ambiente setorial de baixa tecnologia (BT) e com regime de apropriabilidade fraco (FR). 
Tabela 4.31 - Resultados das regressões logísticas para os modelos estimados $Y_{\text {socl }}$ referentes aos estratos BT/FR

\begin{tabular}{|c|c|c|c|c|}
\hline \multicolumn{5}{|c|}{ Modelos estimados $Y_{\text {socl }}$ referentes aos estratos BT/FR } \\
\hline Parâmetro & $\begin{array}{l}\text { Coeficiente } \\
\text { estimado }(\beta)\end{array}$ & $\begin{array}{l}\text { Erro } \\
\text { padrão }(\varepsilon)\end{array}$ & $\begin{array}{l}\text { Wald } \\
\text { Qui quadrado }\end{array}$ & $\begin{array}{l}\text { Significância } \\
\left(\operatorname{Pr}>X^{2}\right)\end{array}$ \\
\hline \multicolumn{5}{|c|}{ Estrato BT/FR- Micro e pequenas empresas } \\
\hline Intercepto & 25,306 & 0,8152 & 96,363 & $0,0019^{* *}$ \\
\hline \multicolumn{5}{|l|}{ Variável explanatória } \\
\hline$X_{F O R N}$ & 0,6115 & 0,1674 & 133,419 & $0,0003^{* * *}$ \\
\hline$X_{\text {ICTS }}$ & 0,4665 & 0,2086 & 50,002 & $0,0253^{*}$ \\
\hline$X_{C C A P}$ & 0,7091 & 0,2258 & 98,627 & $0,0017^{\star *}$ \\
\hline $\begin{array}{l}\text { Qualidade de ajuste do } \\
\text { modelo }\end{array}$ & & & Qui quadrado & $\begin{array}{l}\text { Significância } \\
\left(\operatorname{Pr}>X^{2}\right)\end{array}$ \\
\hline $\begin{array}{l}\text { Capacidade preditiva } \\
\text { (Índice c) }\end{array}$ & 0,755 & & & \\
\hline Razão de verossimilhança & 307,718 & & & $<0,0001^{* * *}$ \\
\hline $\begin{array}{l}\text { Log-verossimilhança } \\
\text { (modelo nulo) }\end{array}$ & 203,682 & & & \\
\hline $\begin{array}{l}\text { Log-verossimilhança } \\
\text { (modelo estimado) }\end{array}$ & 172,910 & & & \\
\hline $\begin{array}{l}\text { Teste de Hosmer- } \\
\text { Lemeshow }\end{array}$ & 21,613 & & & 0,9043 \\
\hline Número de casos & 156 & & & \\
\hline \multicolumn{5}{|c|}{ Estrato BT/FR - Médias empresas } \\
\hline Intercepto & 18,282 & 0,4390 & 173,426 & $<0,0001^{* * *}$ \\
\hline \multicolumn{5}{|l|}{ Variável explanatória } \\
\hline$X_{C C A P}$ & 0,4111 & 0,1272 & 104,418 & $0,0012^{* *}$ \\
\hline $\begin{array}{l}\text { Qualidade de ajuste do } \\
\text { modelo }\end{array}$ & & & Qui quadrado & $\begin{array}{l}\text { Significância } \\
\left(\operatorname{Pr}>X^{2}\right)\end{array}$ \\
\hline $\begin{array}{l}\text { Capacidade preditiva } \\
\text { (Índice c) }\end{array}$ & 0,603 & & & \\
\hline Razão de verossimilhança & 114,421 & & & $0,0007^{\star \star \star *}$ \\
\hline $\begin{array}{l}\text { Log-verossimilhança } \\
\text { (modelo nulo) }\end{array}$ & 345,463 & & & \\
\hline $\begin{array}{l}\text { Log-verossimilhança } \\
\text { (modelo estimado) }\end{array}$ & 334,021 & & & \\
\hline $\begin{array}{l}\text { Teste de Hosmer- } \\
\text { Lemeshow }\end{array}$ & 43,256 & & & 0,1150 \\
\hline Número de casos & 261 & & & \\
\hline \multicolumn{5}{|c|}{ Estrato BT/FR - Grandes empresas } \\
\hline Intercepto & 16,495 & 0,5550 & 88,346 & $0,0030^{* *}$ \\
\hline \multicolumn{5}{|l|}{ Variável explanatória } \\
\hline$X_{\text {CONC }}$ & 0,3741 & 0,1562 & 57,377 & $0,0166^{*}$ \\
\hline $\begin{array}{l}\text { Qualidade de ajuste do } \\
\text { modelo }\end{array}$ & & & Qui quadrado & $\begin{array}{l}\text { Significância } \\
\left(\operatorname{Pr}>X^{2}\right)\end{array}$ \\
\hline $\begin{array}{l}\text { Capacidade preditiva } \\
\text { (Índice c) }\end{array}$ & 0,605 & & & \\
\hline Razão de verossimilhança & 62,335 & & & $0,0125^{*}$ \\
\hline $\begin{array}{l}\text { Log-verossimilhança } \\
\text { (modelo nulo) }\end{array}$ & 257,569 & & & \\
\hline $\begin{array}{l}\text { Log-verossimilhança } \\
\text { (modelo estimado) }\end{array}$ & 251,336 & & & \\
\hline $\begin{array}{l}\text { Teste de Hosmer- } \\
\text { Lemeshow }\end{array}$ & 52,746 & & & 0,0716 \\
\hline Número de casos & 191 & & & \\
\hline
\end{tabular}


Procedeu-se à análise dos resultados apresentados na tabela 4.31, com o objetivo de testar as hipóteses de pesquisa relativas aos modelos estimados $Y_{S O C I}$ para os estratos BT/FR. Confirmaram-se as hipóteses H2.4; H3.4; H6.4; e H7.4, como mostra o quadro 4.25 abaixo.

Quadro 4.25 - Resultados das hipóteses de pesquisa dos modelos $Y_{S O C I}$ referentes aos estratos BT/FR

\begin{tabular}{|c|c|c|}
\hline Hipótese & Descrição & Resultado \\
\hline H1.4 & $\begin{array}{l}\text { A cooperação com clientes e consumidores } \\
\text { influencia positivamente a apropriação de valor das } \\
\text { inovações geradas em arranjos cooperativos, pelos } \\
\text { seus impactos sociais. }\end{array}$ & Não confirmada. \\
\hline H2.4 & $\begin{array}{l}\text { A cooperação com fornecedores influencia } \\
\text { positivamente a apropriação de valor das inovações } \\
\text { geradas em arranjos cooperativos, pelos seus } \\
\text { impactos sociais. }\end{array}$ & $\begin{array}{l}\text { Confirmada para o estrato } \\
\text { BT/FR - Micro e pequenas empresas } \\
\text { Coeficiente estimado }(\beta)=0,6115\end{array}$ \\
\hline H3.4 & $\begin{array}{l}\text { A cooperação com concorrentes influencia } \\
\text { positivamente a apropriação de valor das inovações } \\
\text { geradas em arranjos cooperativos, pelos seus } \\
\text { impactos sociais. }\end{array}$ & $\begin{array}{l}\text { Confirmada para o estrato } \\
\text { BT/FR - Grandes empresas } \\
\text { Coeficiente estimado }(\beta)=0,3741\end{array}$ \\
\hline H4.4 & $\begin{array}{l}\text { A cooperação com outra empresa do grupo influencia } \\
\text { positivamente a apropriação de valor das inovações } \\
\text { geradas em arranjos cooperativos, pelos seus } \\
\text { impactos sociais. }\end{array}$ & Não confirmada. \\
\hline H5.4 & $\begin{array}{l}\text { A cooperação com empresas de consultoria } \\
\text { influencia positivamente a apropriação de valor das } \\
\text { inovações geradas em arranjos cooperativos, pelos } \\
\text { seus impactos sociais. }\end{array}$ & Não confirmada. \\
\hline H6.4 & $\begin{array}{l}\text { A cooperação com universidades e institutos de } \\
\text { pesquisa influencia positivamente a apropriação de } \\
\text { valor das inovações geradas em arranjos } \\
\text { cooperativos, pelos seus impactos sociais. }\end{array}$ & $\begin{array}{l}\text { Confirmada para o estrato } \\
\text { BT/FR - Micro e pequenas empresas } \\
\text { Coeficiente estimado }(\beta)=0,4665\end{array}$ \\
\hline H7.4 & $\begin{array}{l}\text { A cooperação com centros de capacitação } \\
\text { profissional e assistência técnica influencia } \\
\text { positivamente a apropriação de valor das inovações } \\
\text { geradas em arranjos cooperativos, pelos seus } \\
\text { impactos socais. }\end{array}$ & $\begin{array}{l}\text { Confirmada para dois estratos } \\
\text { BT/FR - Micro e pequenas empresas } \\
\text { Coeficiente estimado }(\beta)=0,7091 \\
\text { BT/FR - Médias empresas } \\
\text { Coeficiente estimado }(\beta)=0,4111\end{array}$ \\
\hline H8.4 & $\begin{array}{l}\text { A cooperação com instituições de ensaios e } \\
\text { certificações influencia positivamente a apropriação } \\
\text { de valor das inovações geradas em arranjos } \\
\text { cooperativos, pelos seus impactos sociais. }\end{array}$ & Não confirmada. \\
\hline
\end{tabular}

Fonte: Elaboração própria.

\subsubsection{5}

\section{Modelos estimados $Y_{R E G U}$}

A tabela 4.32 reúne os resultados obtidos dos coeficientes de regressão em relação aos modelos estimados $Y_{R E G U}$ para micro e pequenas, médias e grandes empresas de transformação que implementaram inovações com cooperação interorganizacional em um ambiente setorial de baixa tecnologia (BT) e com regime de apropriabilidade fraco (FR). 
Tabela 4.32 - Resultados das regressões logísticas para os modelos estimados YREGU referentes aos estratos BT/FR

\begin{tabular}{|c|c|c|c|c|}
\hline \multicolumn{5}{|c|}{ Modelos estimados $Y_{R E G U}$ referentes aos estratos BT/FR } \\
\hline Parâmetro & $\begin{array}{l}\text { Coeficiente } \\
\text { estimado }(\beta)\end{array}$ & $\begin{array}{l}\text { Erro } \\
\text { padrão }(\varepsilon)\end{array}$ & $\begin{array}{l}\text { Wald } \\
\text { Qui quadrado }\end{array}$ & $\begin{array}{l}\text { Significância } \\
\left(\operatorname{Pr}>X^{2}\right)\end{array}$ \\
\hline \multicolumn{5}{|c|}{ Estrato BT/FR - Micro e pequenas empresas } \\
\hline Parâmetro & $\begin{array}{l}\text { Coeficiente } \\
\text { estimado }(\beta)\end{array}$ & $\begin{array}{l}\text { Erro } \\
\text { padrão }(\varepsilon)\end{array}$ & $\begin{array}{l}\text { Wald } \\
\text { Qui quadrado }\end{array}$ & $\begin{array}{l}\text { Significância } \\
\left(\operatorname{Pr}>X^{2}\right)\end{array}$ \\
\hline Intercepto & 31,210 & 0,7359 & 179,872 & $<0,0001^{* * *}$ \\
\hline \multicolumn{5}{|l|}{ Variável explanatória } \\
\hline$X_{C E R T}$ & 0,8007 & 0,2011 & 158,580 & $<0,0001^{* \star *}$ \\
\hline $\begin{array}{l}\text { Qualidade de ajuste do } \\
\text { modelo }\end{array}$ & & & Qui quadrado & $\begin{array}{l}\text { Significância } \\
\left(\mathrm{Pr}>\mathrm{X}^{2}\right)\end{array}$ \\
\hline $\begin{array}{l}\text { Capacidade preditiva } \\
\text { (Índice c) }\end{array}$ & 0,680 & & & \\
\hline Razão de verossimilhança & & & 215,155 & $<0,0001^{* * *}$ \\
\hline $\begin{array}{l}\text { Log-verossimilhança } \\
\text { (modelo nulo) }\end{array}$ & 209,651 & & & \\
\hline $\begin{array}{l}\text { Log-verossimilhança } \\
\text { (modelo estimado) }\end{array}$ & 188,136 & & & \\
\hline $\begin{array}{l}\text { Teste de Hosmer- } \\
\text { Lemeshow }\end{array}$ & & & 0,3198 & 0,8522 \\
\hline Número de casos & 156 & & & \\
\hline \multicolumn{5}{|c|}{ Estrato BT/FR - Médias empresas } \\
\hline Intercepto & 20,961 & 0,4502 & 216,828 & $<0,0001^{* \star *}$ \\
\hline \multicolumn{5}{|l|}{ Variável explanatória } \\
\hline$X_{\text {CLIE }}$ & 0,2975 & 0,1067 & 77,725 & $0,0053^{\star *}$ \\
\hline$X_{C C A P}$ & 0,3207 & 0,1301 & 60,758 & $0,0137^{*}$ \\
\hline $\begin{array}{l}\text { Qualidade de ajuste do } \\
\text { modelo }\end{array}$ & & & Qui quadrado & $\begin{array}{l}\text { Significância } \\
\left(\operatorname{Pr}>X^{2}\right)\end{array}$ \\
\hline $\begin{array}{l}\text { Capacidade preditiva } \\
\text { (Índice c) }\end{array}$ & 0,660 & & & \\
\hline Razão de verossimilhança & & & 201,021 & $<0,0001^{* * *}$ \\
\hline $\begin{array}{l}\text { Log-verossimilhança } \\
\text { (modelo nulo) }\end{array}$ & 350,145 & & & \\
\hline $\begin{array}{l}\text { Log-verossimilhança } \\
\text { (modelo estimado) }\end{array}$ & 330,043 & & & \\
\hline $\begin{array}{l}\text { Teste de Hosmer- } \\
\text { Lemeshow }\end{array}$ & & & 20,066 & 0,9191 \\
\hline Número de casos & 261 & & & \\
\hline \multicolumn{5}{|c|}{ Estrato BT/FR - Grandes empresas } \\
\hline Intercepto & 20,384 & 0,5904 & 119,205 & $0,0006^{* * *}$ \\
\hline \multicolumn{5}{|l|}{ Variável explanatória } \\
\hline$X_{\text {CONC }}$ & 0,4739 & 0,1646 & 82,884 & $0,0040^{* *}$ \\
\hline $\begin{array}{l}\text { Qualidade de ajuste do } \\
\text { modelo }\end{array}$ & & & Qui quadrado & $\begin{array}{l}\text { Significância } \\
\left(\operatorname{Pr}>X^{2}\right)\end{array}$ \\
\hline $\begin{array}{l}\text { Capacidade preditiva } \\
\text { (Índice c) }\end{array}$ & 0,606 & & & \\
\hline Razão de verossimilhança & & & 93,983 & $0,0222^{*}$ \\
\hline $\begin{array}{l}\text { Log-verossimilhança } \\
\text { (modelo nulo) }\end{array}$ & 255,912 & & & \\
\hline $\begin{array}{l}\text { Log-verossimilhança } \\
\text { (modelo estimado) }\end{array}$ & 246,514 & & & \\
\hline $\begin{array}{l}\text { Teste de Hosmer- } \\
\text { Lemeshow }\end{array}$ & & & 0,0749 & 0,9632 \\
\hline Número de casos & 191 & & & \\
\hline
\end{tabular}


A análise dos resultados apresentados na tabela 4.32, visando testar as hipóteses de pesquisa relativas aos modelos estimados $Y_{R E G U}$ para os estratos BT/FR permitiu a confirmação das hipóteses H1.5; H3.5; H7.5; e H8.5, conforme mostrado no quadro 4.26 abaixo.

Quadro 4.26 - Resultados das hipóteses de pesquisa dos modelos $Y_{R E G U}$ referentes aos estratos BT/FR

\begin{tabular}{|c|c|c|}
\hline Hipótese & Descrição & Resultado \\
\hline H1.5 & $\begin{array}{l}\text { A cooperação com clientes e consumidores influencia } \\
\text { positivamente a apropriação de valor das inovações } \\
\text { geradas em arranjos cooperativos, pelos seus impactos } \\
\text { regulatórios. }\end{array}$ & $\begin{array}{l}\text { Confirmada para o estrato } \\
\text { BT/FR - Médias empresas } \\
\text { Coeficiente estimado }(\beta)= \\
0,2975\end{array}$ \\
\hline H2.5 & $\begin{array}{l}\text { A cooperação com fornecedores influencia positivamente } \\
\text { a apropriação de valor das inovações geradas em } \\
\text { arranjos cooperativos, pelos seus impactos regulatórios. }\end{array}$ & Não confirmada. \\
\hline H3.5 & $\begin{array}{l}\text { A cooperação com concorrentes influencia } \\
\text { positivamente a apropriação de valor das inovações } \\
\text { geradas em arranjos cooperativos, pelos seus impactos } \\
\text { regulatórios. }\end{array}$ & $\begin{array}{l}\text { Confirmada para o estrato } \\
\text { BT/FR - Grandes empresas } \\
\text { Coeficiente estimado }(\beta)= \\
0,4739\end{array}$ \\
\hline H4.5 & $\begin{array}{l}\text { A cooperação com outra empresa do grupo influencia } \\
\text { positivamente a apropriação de valor das inovações } \\
\text { geradas em arranjos cooperativos, pelos seus impactos } \\
\text { regulatórios. }\end{array}$ & Não confirmada. \\
\hline H5.5 & $\begin{array}{l}\text { A cooperação com empresas de consultoria influencia } \\
\text { positivamente a apropriação de valor das inovações } \\
\text { geradas em arranjos cooperativos, pelos seus impactos } \\
\text { regulatórios. }\end{array}$ & Não confirmada. \\
\hline H6.5 & $\begin{array}{l}\text { A cooperação com universidades e institutos de pesquisa } \\
\text { influencia positivamente a apropriação de valor das } \\
\text { inovações geradas em arranjos cooperativos, pelos seus } \\
\text { impactos regulatórios. }\end{array}$ & Não confirmada. \\
\hline H7.5 & $\begin{array}{l}\text { A cooperação com centros de capacitação profissional e } \\
\text { assistência técnica influencia positivamente a } \\
\text { apropriação de valor das inovações geradas em arranjos } \\
\text { cooperativos, pelos seus impactos regulatórios. }\end{array}$ & $\begin{array}{l}\text { Confirmada para o estrato } \\
\text { BT/FR - Médias empresas } \\
\text { Coeficiente estimado }(\beta)= \\
0,3207\end{array}$ \\
\hline H8.5 & $\begin{array}{l}\text { A cooperação com instituições de ensaios e certificações } \\
\text { influencia positivamente a apropriação de valor das } \\
\text { inovações geradas em arranjos cooperativos, pelos seus } \\
\text { impactos regulatórios. }\end{array}$ & $\begin{array}{l}\text { Confirmada para o estrato } \\
\text { BT/FR - Micro e pequenas } \\
\text { empresas } \\
\text { Coeficiente estimado }(\beta)= \\
0,8007\end{array}$ \\
\hline
\end{tabular}

Fonte: Elaboração própria.

\subsubsection{6}

\section{Discussão dos resultados do agrupamento setorial BT/FR}

As empresas de menor porte buscam cooperação com fornecedores, universidades e institutos de pesquisa e instituições de ensaios e certificações, visando melhorar as condições de saúde e segurança para seus colaboradores e/ou clientes e atender a requisitos de regulamentos e normas aplicáveis. Também com universidades e institutos de pesquisa conseguem criar inovações com impactos mercadológicos. Com instituições de ensaios e certificações, visam atender a exigências ambientais legais de suas próprias empresas e/ou de seus clientes. 
Consistentes com estudos anteriores, os resultados empíricos obtidos até o momento mostram que as micro, pequenas e médias empresas da indústria de transformação no Brasil seguem estratégias de parcerias distintas, de acordo com o ambiente setorial em que atuam, caracterizado pela intensidade tecnológica e força do regime de apropriabilidade.

Por sua vez, as empresas as empresas de médio porte deste agrupamento setorial (BT/FR) buscam cooperação com centros de capacitação profissional para inovações com impactos ambientais e sociais. Com concorrentes e empresas de consultoria, buscam melhorias e/ou mudanças em seus processos de produção. Já com empresas de ensaios e certificações, inovações têm impactos ambientais para as próprias empresas e/ou seus clientes.

Finalmente, as grandes empresas buscam cooperação com clientes e consumidores; concorrentes; e instituições de ensaios e certificações. Com clientes e consumidores, as inovações tiveram impactos mercadológicos e na produção. Com os concorrentes, criaram inovações com impactos sociais e regulatórios. Já com instituições de ensaios e certificações, as inovações tiveram impactos ambientais para as próprias empresas e/ou seus clientes.

\section{6}

\section{Síntese e discussão dos resultados do estudo empírico}

Neste capítulo, buscou-se analisar a influência da cooperação interorganizacional na apropriação de valor pela criação de inovações por empresas classificadas por agrupamento setorial (intensidade tecnológica e regimes de apropriabilidade distintos) e por tamanho (micro e pequenas; médias; e grandes empresas).

Foi possível demonstrar que o tamanho da empresa, a força do regime de apropriabilidade e a intensidade tecnológica setorial influenciam as escolhas de parceiros estratégicos por parte das empresas brasileiras da indústria de transformação, quando do desenvolvimento conjunto de projetos de PD\&I.

A diversidade de tipos de parceiros nos quatro agrupamentos (AT/FO/ AT/FR; BT/FO; ou BT/FR) pode ser estimada nos modelos de regressão, como evidenciado pelos resultados apresentados nas tabelas 4.14 a 4.33 . Em termos de formação de parcerias é relativamente fácil de explicar. Isolando-se clientes e consumidores, que aparecem como principais parceiros de empresas em diversos 
agrupamentos, constata-se que há uma diversidade de parceiros preferenciais quando as condições ambientais e características internas das empresas mudam. Mostrou-se que, por exemplo, empresas de consultoria não são parceiros preferenciais para empresas que atuam em setores BT/FR.

O tamanho da empresa, por sua vez, também tem uma influência nos arranjos cooperativos para desenvolvimento conjunto de projetos de PD\&I. As inovações tecnológicas resultantes de parcerias das empresas de menor porte com outras organizações estão mais voltadas para o mercado e o atendimento aos requisitos de regulamentos e normas aplicáveis.

Observou-se que na maioria dos setores da indústria de transformação, intensivos ou não em tecnologia, prevalece uma estratégia das grandes empresas de criarem inovações na perspectiva da entrada em novos mercados, independente da força do regime de apropriabilidade do setores em que atuam. Além disso, essas empresas precisam estar continuamente preparadas para atender às novas demandas e enfrentar ameaças que possam surgir em seus ambientes de negócios. Isso significa dizer que elas precisam encontrar parceiros adequados, o que explica a tendência da busca de clientes e consumidores como principais parceiros das grandes empresas. Única exceção foi observada no agrupamento de empresas que atuam em ambientes de alta intensidade tecnológica (AT) e regime de apropriabilidade fraco (FR).

Apresenta-se no quadro 4.27 a síntese dos resultados do estudo empírico foco desta dissertação. Ao dispor esses resultados segundo o enquadramento inicial da pesquisa (quadro 1.1, no capítulo introdutório), torna-se possível evidenciar e comparar visualmente a influência de diferentes tipos de parceiros em arranjos cooperativos para desenvolvimento conjunto de projetos de PD\&I sobre a apropriação de valor das inovações geradas por empresas da indústria de transformação no Brasil no período 2012 - 2014. 
Quadro 4.27 - Síntese dos resultados do estudo empírico, segundo enquadramento conceitual da pesquisa

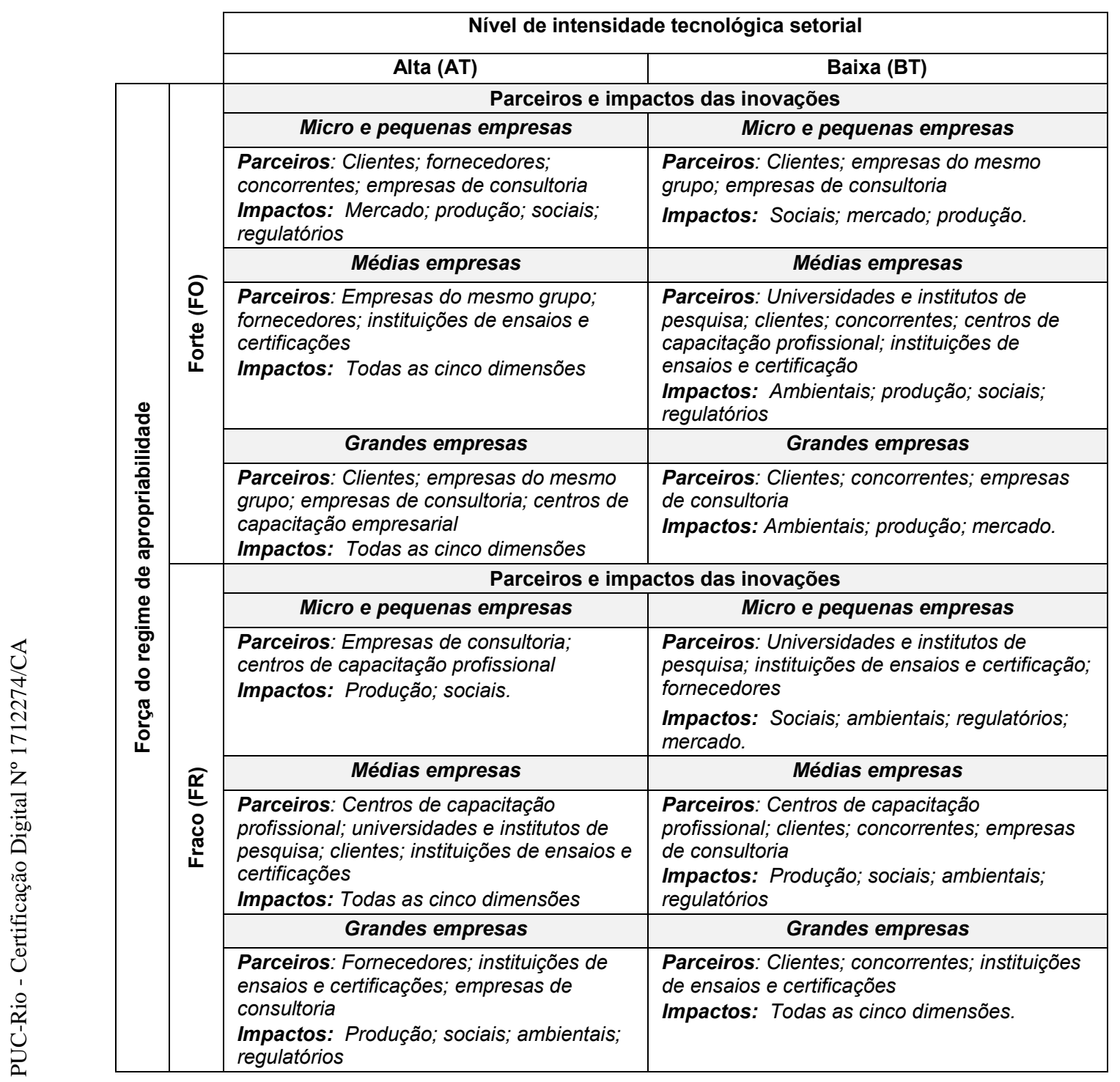




\section{5 \\ Conclusões}

A presente pesquisa contribuiu para o avanço do conhecimento sobre as relações entre cooperação interorganizacional em projetos de PD\&I e a apropriação de valor pela criação de inovações tecnológicas, considerando condições ambientais distintas (força do regime de apropriabilidade e intensidade tecnológica dos setores em que as empresas atuam) e diferentes características internas (como tamanho da empresa e capacidade inovativa). Os resultados obtidos ao longo da pesquisa aqui relatada permitiram que o objetivo geral da dissertação fosse alcançado.

Em resposta às questões norteadoras da pesquisa, um estudo empírico foi desenvolvido com o objetivo de analisar e comparar a influência de diferentes tipos de parceiros em arranjos cooperativos para projetos de PD\&I sobre a apropriação de valor das inovações geradas pelas empresas da indústria de transformação no Brasil, tendo como fonte de dados a Pintec 2014, realizada pelo IBGE. Nesse sentido, cabe destacar que, sem a liberação do Instituto para acesso aos microdados não desidentificados da Pintec 2014 e participação de um de seus tecnologistas como procurador interno deste projeto de pesquisa, o estudo relatado nesta dissertação não teria sido desenvolvido.

A análise dos estudos empíricos sobre a temática abordada na presente pesquisa permitiu concluir que muitos já abordaram, separadamente ou de forma integrada, os temas cooperação interorganizacional e apropriação de valor pela criação de inovações. A maioria foi desenvolvida em países europeus (Alemanha; Bélgica; Espanha; Finlândia, França; Holanda; Itália; e Reino Unido;); dois na Ásia (Coreia e China); um no Brasil e outro nos EUA. Constatou-se também que poucos foram os estudos empíricos que abordaram os dois temas centrais, buscando correlacionar variáveis a eles associadas (Hurmelinna-Laukkanen, 2011; Henttonen, Hurmelinna-Laukkanen e Ritala, 2016; Veer, Lorenz e Blind, 2016; Pereira, 2017; e Lorenz e Veer, 2019). Não obstante a importância dos 
resultados desses estudos para o avanço do conhecimento na temática em foco, concluiu-se que a análise das contribuições de diferentes tipos de parceiros em arranjos de cooperação interorganizacional entre empresas da indústria de transformação para a apropriação de valor pela criação de suas inovações, considerando condições ambientais distintas e diferentes características internas não havia sido foco de nenhum desses trabalhos. Assim, o modelo conceitual proposto no final do capítulo 2 deve ser assumido como uma das principais contribuições desta pesquisa.

Com o desenvolvimento do estudo empírico, chegou-se a 60 modelos de regressão logística ajustados (tabelas 4.13 a 4.32) e a importantes resultados referentes ao período 2012-2014, que permitiram afirmar que:

- No agrupamento de empresas classificadas em setores de intensidade tecnológica alta e forte regime de apropriabilidade (AT/FO):

- As micro e pequenas empresas buscaram envolver clientes e consumidores em seus projetos de PD\&I e as inovações resultantes tiveram impactos mercadológicos e sociais. A cooperação com concorrentes associou-se a resultados de PD\&I com impactos na eficiência operacional de seus processos produtivos. Já a cooperação com empresas de consultoria e fornecedores geraram inovações com impactos regulatórios;

- As médias empresas em seus arranjos cooperativos para inovar tiveram como principal parceiro outra empresa do grupo, com impactos de suas inovações no mercado e na produção, além de impactos sociais. A cooperação com fornecedores propiciou a geração de inovações com impactos regulatórios. Com instituições de ensaios e certificações os impactos das inovações resultantes referem-se a impactos ambientais;

- Já para as grandes empresas, os parceiros preferenciais em arranjos cooperativos para inovar foram os clientes e consumidores, com impactos ambientais e sociais; e no mercado. Em segundo lugar, os arranjos com outra empresa do grupo e empresas de consultoria e assistência técnica propiciaram a criação de inovações com impactos regulatórios.

- No agrupamento de empresas classificadas em setores de intensidade tecnológica alta e fraco regime de apropriabilidade (AT/FR): 
- As micro e pequenas empresas buscaram empresas de consultoria e centros de capacitação profissional como parceiros para seus projetos de PD\&I e as inovações resultantes tiveram impactos na produção e sociais, respectivamente;

- As médias empresas em seus arranjos cooperativos para inovar tiveram como principal parceiro os centros de capacitação profissional, com impactos em quase todas as dimensões abordadas, menos impactos no mercado. Cooperação com universidades e institutos de pesquisa resultou em inovações com impactos sociais;

- Já para as grandes empresas, os parceiros preferenciais em arranjos cooperativos para inovar foram as instituições de ensaios e certificações, com impactos sociais e regulatórios. Cooperação com empresas de consultoria resultaram em inovações com impactos na produção; e arranjos cooperativos com fornecedores permitiram criar inovações com impactos ambientais e na produção.

- No agrupamento de empresas classificadas em setores de intensidade tecnológica baixa e forte regime de apropriabilidade (BT/FO):

- As micro e pequenas empresas tiveram como principais parceiros seus clientes e consumidores para seus projetos de PD\&I e as inovações resultantes tiveram impactos sociais e na produção. Cooperação com outra empresa do grupo correlaciona-se com impactos no mercado propiciados pelas inovações resultantes e arranjos cooperativos com empresas de consultoria geraram inovações com impactos sociais;

- As médias empresas em seus arranjos cooperativos para inovar tiveram como principais parceiros as universidades e institutos de pesquisa, com impactos ambientais e na produção. Outros parceiros importantes foram concorrentes e instituições de ensaios e certificação, cujas inovações tiveram impactos ambientais. A cooperação com centros de capacitação profissional resultou em inovações com impactos sociais;

- Já para as grandes empresas, os parceiros preferenciais em arranjos cooperativos para inovar foram os clientes e consumidores, cujas inovações tiveram impactos ambientais, no mercado e na produção. As empresas de consultoria também foram parceiros 
importantes nos arranjos cooperativos e a apropriação de valor pela criação conjunta de inovações referiu-se a impactos ambientais.

- Finalmente, no agrupamento de empresas classificadas em setores de intensidade tecnológica baixa e fraco regime de apropriabilidade (BT/FR):

- As micro e pequenas empresas buscaram preferencialmente universidades e institutos de pesquisa, bem como instituições de ensaios e certificação como parceiros para seus projetos de PD\&I, e as inovações resultantes tiveram impactos ambientais, sociais e no mercado. A cooperação com centros de capacitação profissional levou a inovações com impactos sociais;

- As médias empresas em seus arranjos cooperativos para inovar tiveram como principais parceiros os centros de capacitação profissional, com impactos sociais e regulatórios. Outros parceiros foram empresas de consultoria, concorrentes e instituições de ensaios e certificações, gerando inovações com impactos ambientais e na produção;

- Já para as grandes empresas, os parceiros preferenciais em arranjos cooperativos para inovar foram os clientes e consumidores, com impactos no mercado e na produção; e com empresas concorrentes, gerando inovações com impactos regulatórios e sociais.

Ao se comparar os resultados dos modelos de regressão logística para os quatro agrupamentos de empresas (AT/FO/AT/FR; BT/FO; e BT/FR), constatouse que a escolha dos parceiros varia de agrupamento para agrupamento (condições setoriais) e também em função do tamanho das empresas e de sua capacidade de inovar em arranjos cooperativos com outras organizações (características internas).

Para trabalhos futuros de desdobramento da pesquisa e aprofundamento dos resultados, propõem-se:

- Estender a abordagem metodológica adotada no estudo empírico objeto da presente pesquisa a outros setores contemplados na Pesquisa Nacional de Inovação (indústria extrativa; serviços; eletricidade e gás) e comparar os resultados com os da indústria de transformação;

- Replicar o estudo empírico da indústria de transformação para outros horizontes temporais $(2002 ; 2005 ; 2008 ; 2011 ; 2017)$ e comparar os resultados para identificar tendências e sinais de mudança nos arranjos 
cooperativos e sua relação com apropriação de valor pela criação de inovações nessa indústria;

- Desenvolver estudos comparativos sobre cooperação interorganizacional para inovação e apropriação de valor pela criação de inovações, em países de economia emergente (Brasil, inclusive), tendo como fontes de dados as pesquisas nacionais de inovação dos países selecionados;

- Analisar outros fatores que influenciam a escolha de parceiros em arranjos cooperativos para desenvolvimento de projetos de PD\&I, dentre variáveis da Pintec que não consideradas na presente pesquisa;

- Analisar a influência da localização geográfica das empresas da indústria de transformação na escolha de parceiros em arranjos cooperativos para desenvolvimento de projetos de PD\&I e sua relação com a apropriação de valor pelas inovações criadas no âmbito desses arranjos;

- Explorar outros métodos de análise nos próximos estudos empíricos sobre cooperação interorganizacional em projetos de PD\&I e apropriação de valor pela criação de inovações, tendo como fonte de dados a Pesquisa Nacional de Inovação. 


\section{Referências bibliográficas}

ADAMS, R.; BESSANT, J.; PHELPS, R. Innovation management measurement: a review. International Journal of Management Reviews, v.8, p.21-47, 2006.

AHUJA, G.; LAMPERT, C.M.; NOVELLI, E. The second face of appropriability: generative appropriability and its determinants. Academy of Management Review, v.38, p.248-269, 2013.

ALDRICH, J. H.; NELSON, F. D. Linear probability, logit,and probit models. London: Sage, 1984.

ALMEIDA, M. F. L.; BARRETO JR. J. T.; FROTA, M. N. Regime de apropriabilidade e apropriação econômica de resultados de P\&D: o caso de uma empresa concessionária de energia elétrica. In: XXXVI ENAPAD, Rio de Janeiro/RJ - 22-26 de setembro, 2012.

ARCHIBUGI, D. Pavitt's taxonomy sixteen years on: a review article. Economics of Innovation and New Technology, v.10, p. 415-425, 2001.

ARRANZ, N.; ARROYABE, J. The choice of partners in R\&D cooperation: an empirical analysis of Spanish firms. Technovation, v.28, n.1, p.88-100, 2008.

ARROW, K. Economic welfare and the allocation of resources for invention. In: R Nelson (ed.) The rate and direction of inventive activity: economic and social factors (p. 609-625). New York: Princeton University Press, 1962.

BARDIN, L. Análise de conteúdo. Lisboa: Edições 70, 2011.

BAREGHEH, A.; ROWLEY, J.; SAMBROOK, S. Towards a multidisciplinary definition of innovation. Management Decision, v. 47, n. 8, p. 1323-1339, 2009.

BASBERG, B. L. Patents and the measurement of technological change: A survey of the literature. Research Policy, v. 16, p. 131-141, 1987.

BAYONA, C.; CARCIA-MARCO, T.; ANDHUERTA, E. Firms' motivations for cooperative R\&D: an empirical analysis of Spanish firms. Research Policy, v.30, p.1289-1307, 2001.

BOLDRIN, M.; LEVINE, D.K. Perfectly competitive innovation. Journal of Monetary Economics, v.55, p. 435-453, 2008.

BÖNTE, W.; KEILBACH, B. Concubinage or marriage? Informal and formal cooperations for innovation. International Journal of Industrial Organization, v. 23, n.3, p. 279-302, 2005. 
BUAINAIN, A. M.; CARVALHO, S. M. P DE.; PAULINO, S. R.; YAMAMURA, S. Propriedade intelectual e inovação tecnológica: algumas questões para o debate atual. In: OLIVEIRA, D. H. de. (org.). O futuro da indústria: cadeias produtivas. Brasília, v. 1, p. 11-38, 2005.

CAPALDO, A.; PETRUZZELLI, A. M. In search of alliance-level relational capabilities: balancing innovation value creation and appropriability in $R \& D$ alliances. Scandinavian Journal of Management, v.27, n.3, p.273-286, 2011.

CARVALHO, M.O.G.; ALMEIDA, M.F.L.; TRINDADE, J.E.O. Firm size, technological intensity, and informal appropriation mechanisms in innovative manufacturing firms. In: Proceedings of the 28th International Conference for Management of Technology. Mumbai: IAMOT, 2019.

CÁSSIA, A. R.; ZILBER, S.N. Orientação estratégica e atividades inovativas: uma análise a partir dos dados da PINTEC no período de 1998 a 2011. Gestão e Produção, v. 23, n. 3, p. 447-458, 2016.

CAVALCANTE, L.R. Classificações tecnológicas: uma sistematização. Instituto de Pesquisa Econômica Aplicada. IPEA. Nota Técnica no 17. Brasília: IPEA, 2014.

CEFIS, E.; MARSILI, O. Survivor: the role of innovation in firms' survival. Research Policy, v.35, n.5, p. 626-641, 2006.

CHRISTENSEN, C. M. The innovator's dilemma: when new technologies cause great firms to fail. Boston, Massachusetts: Harvard Business School Press, 1997.

COHEN, W.; NELSON, R.; WALSH, J. P. Protecting their intellectual assets: appropriability conditions and why US manufacturing firms patent (or not). National Bureau of Economic Research Working Paper No. 7552, 2000.

CROSSAN, M. M.; APAYDIN, M.A. Multi-dimensional framework of organizational innovation: a systematic review of the literature. Journal of Management Studies, v.47, n.6, p. 1155 - 1188, 2010.

CRUZ, P. A.M. et al. A eficiência das inovações tecnológicas no Brasil: uma analise sobre a indústria de transformação. Rev. Econ. NE, v. 46, n. 3, p. 27-40, 2015 .

CZARNITZKI, D.; HUSSINGER, K.; SCHNEIDER, C. R\&D collaboration with uncertain intellectual property rights. Review of Industrial Organization, v.46, p.183-204, 2015.

DACHS, B.; EBERSBERGER, B.; PYKA, A. Why do firms cooperate for innovation? A comparison of Austrian and Finnish CIS3 results. Journal International Journal of Foresight and Innovation Policy, v.4, n.3-4, p.200229, 2008. 
DAHLANDER, L.; GANN, D. M. How open is innovation? Research Policy, v.39, n.6, p.699-709, 2010.

DAMANPOUR, F.; SCHNEIDER, M. Phases of the adoption of innovation in organizations: effects of environment, organization and top managers. British Journal of Management, v. 17, n. 3, p. 215-236, 2006.

DAMANPOUR, F.; SZABAT, K.; EVAN, W.M. The relationship between types of innovation and organizational performance. Journal of Management Studies, v. 26, n .6, p.587-601, 1989.

DANNEELS, E. The dynamics of product innovation and firm competences. Strategic Management Journal, v.23, n.12, p.1095-1121, 2002.

DAVILA, T.; EPSTEIN, M. J.; SHELTON, R. As regras da inovação. Porto Alegre: Bookman, 2007.

DOSI, G. Technological paradigms and technological trajectories. The determinants and directions of technical change and the transformation of the economy. In: Freeman, C. (ed.). Long waves in the world economy. London: Frances Pinter, 1982.

DOSI, G. Mudança técnica e transformação industrial: a teoria e uma aplicação à indústria de semicondutores. Campinas: Editora da Unicamp, 2006.

ERNST, D.; GANIATSOS, T.; MYTELKA, L. Technological capabilities and export success in Asia. London: Routledge, 1998.

EUROPEAN UNION INTELLECTUAL PROPERTY OFFICE. EUIPO. Protecting innovation through trade secrets and patents: determinants for European Union firms. Alicante, Spain: EUIPO, 2017.

FEDERAÇÃO DAS INDÚSTRAIS DO ESTADO DE SÃO PAULO. FIESP. Panorama da indústria de transformação brasileira. $18^{\mathrm{a}}$ ed. Última atualização 26 de março de 2019. São Paulo: Departamento de Economia, Competitividade e Tecnologia. FIESP/CIESP, 2019.

FRANCIS, D.; BESSANT, J. Targeting innovation and implications for capability development. Technovation, v. 25, n. 3, p. 171-183, 2005.

FREEMAN, C.; PEREZ, C. Structural crises of adjustment. In: Dosi, Giovanni et al. (eds). Technical change and economic theory. London: Frances Pinter Publishers, 1988.

FREEMAN, C. The economics of industrial innovation. London: Pinter, 1982.

FREEMAN, C. The economics of technological change: a critical survey. Cambridge Journal of Economics, v. 18, p. 463-514, 1994. 
FREEMAN, C.; SOETE, L. Technical change and full employment. London: Pinter, 1997.

FURTADO, A. T.; CARVALHO, R. D. Q. Padrões de intensidade tecnológica da indústria brasileira: um estudo comparativo com os países centrais. São Paulo em Perspectiva, v. 19, p. 70-84, 2005.

GOFFIN, K.; MITCHELL, R. Innovation management: strategy and implementation using the Pentathlon framework. 2nd ed. Basingstoke: Palgrave Macmillan, 2010.

GONÇALVES, E.; SIMÕES, R. Padrões de esforço tecnológico da indústria brasileira: uma análise setorial a partir de técnicas multivariadas. EconomiA, v.6, n.2, p.391-433, 2005.

GOPALAKRISHNAN, S., DAMANPOUR, F. Patterns of generation and adoption of innovation in organizations: contingency models of innovation attributes. Journal of Engineering and Technology Management, v.11, 95116, 1994.

GREENE, W. H. Econometric analysis. $4^{\text {th }}$ ed., Upper Saddle River, N.J.: Prentice Hall, 2000.

HAIR, J. F.; BLACK, W.C.; BABIN, B.J.; ANDERSON, R.E.; TATHAM, R.L. Análise multivariada de dados. Tradução Adonai Schlup Sant'Anna. 6 ed. Porto Alegre: Bookman, 2009.

HALL, B.H.; HELMERS, C.; ROGERS, M.; SENA, V. The choice between formal and informal intellectual property: a literature review. NBER Working Paper Series, WP 17983. Cambridge, MA: National Bureau of Economic Research, 2012.

HARABI, N. Appropriability of technical innovations: an empirical analysis. Research Policy, v.24, p.981-992, 1995.

HATZICHRONOGLOU, T. Revision of the high-technology sector and product classification. OECD Science, Technology and Industry Working Papers, 1997/02, OECD Publishing, Paris, 1997. Disponível em: $<$ https://www.oecd-ilibrary.org/docserver/134337307632.pdf $>$. Acesso em: Acesso em: 02 mar. 2019.

HELFAT, C. E. Firm-specificity in corporate applied R\&D. Organization Science, v.5, p.173-184, 1994.

HENTTONEN. K.; HURMELINNA-LAUKKANEN, P.; RITALA, P. Managing the appropriability of R\&D collaboration. R\&D Management, v. 46, S1, p. 145$158,2016$. 
HIPP, C.B.; HERSTATT, C. Patterns of innovation and protection activities within service companies: results from a German study on service-intensive companies, Working Paper N. 45, Technische Universitat Hamburg-Harburg, 2006.

HOSMER, D. W.; LEMESHOW, S. Applied logistic regression. 2nd. ed. Hoboken, NJ: John Wiley and Sons, 2000.

HURMELINNA, P.; KYLAHEIKO, K.; JAUHIAINEN, T. The Janus face of the appropriability regime in the protection of innovations: theoretical re-appraisal and empirical analysis. Technovation, v.27, p.133-144, 2007.

HURMELINNA, P.; PUUMALAINEN, K. The dynamics of appropriability regimes. In: The DRUID Tenth Anniversary. 27- 29 de julho, 2005. Disponível em: <http://www.druid.dk/uploads/tx_picturedb/ds2005-1522.pdf >. Acesso em: 23 nov. 2018.

HURMELINNA-LAUKKANEN, P.; PUUMALAINEN, K. Nature and dynamics of appropriability: strategies for appropriating returns on innovation. R\&D Management, v. 37, n.2, p. 95-112, 2007.

HURMELINNA-LAUKKANEN, P.; SAINIO, L. M.; JAUHIAINEN, T. Appropriability regime for radical and incremental innovations. R\&D Management, v.38, n.3, p. 278-289, 2008.

HURMELINNA-LAUKKANEN, P. Enabling collaborative innovation knowledge protection for knowledge sharing. European Journal of Innovation Management, v. 14, n. 3, p. 303-321, 2011.

HURMELINNA-LAUKKANEN, P. The availability, strength and efficiency of appropriability mechanisms-protecting investments in knowledge creation, International Journal of Innovation Management, v.45, p. 282-290, 2009.

INSTITUTO BRASILEIRO DE GEOGRAFIA E ESTATÍSTICA. IBGE. Classificação Nacional de Atividades Econômicas - CNAE: versão 2.2. Rio de Janeiro: IBGE, 2015.

INSTITUTO BRASILEIRO DE GEOGRAFIA E ESTATÍSTICA. IBGE. Pesquisa de Inovação. Pintec 2014. Rio de Janeiro: IBGE, 2016. Disponível em: $<$ http://www.ibge.gov.br/>. Acesso em: 02 mar. 2019.

INSTITUTO DE ESTUDOS PARA O DESENVOLVIMENTO INDUSTRIAL. IEDI. Panorama do retrocesso industrial de longo prazo. 2019a. Disponível em: <https://iedi.org.br/artigos/top/analise/analise_iedi_20190326_industria.html >. Acesso em: 02 mai. 2019.

INSTITUTO DE ESTUDOS PARA O DESENVOLVIMENTO INDUSTRIAL. IEDI. O perfil setorial do retrocesso da indústria brasileira. 2019b. Disponível em: $<$ https://iedi.org.br/cartas/carta_iedi_n_920.html>. Acesso em: 02 mai. 2019. 
JACOBIDES, M. G.; KNUDSEN, T. T.; AUGIER, M. Benefiting from innovation: value creation, value appropriation and the role of industry architectures. Research Policy, v. 35, n. 8, p. 1200-1221, 2006.

JAMES, S.D.; LEIBLEIN, M.J.; LU, S. How firms capture value from their innovations. Journal of Management, v.39, p.1123-1155, 2013.

KAY, N. The R\&D function: corporate strategy and structure. In: Dosi, G.; Freeman, C.; Nelson, R.; Silverberg, G.; Soete, L. (eds.), Technical change and economic theory. Londres: Pinter Publishers, 1988.

LAWSON, B.; SAMSON, D.; RODEN, S. Appropriating the value from innovation: inimitability and the effectiveness of isolating mechanisms. R\&D Management, v.42, p.420-434, 2012

LEVIN, R.C.; KLEVORICK, ALVIN K.; NELSON, R.R.; WINTER, S.G. Appropriating the returns from industrial research and development. Brookings Papers on Economic Activity, v.3, p.783-831, 1987.

LHUILLERY, S.; PFISTER, E. R\&D cooperation and failures in innovation projects: empirical evidence from French CIS data. Research Policy, v.38, n.1, p.45-57, 2009.

LIPPMAN, S.A.; RUMELT, R.P. Uncertain imitability: an analysis of interfirm differences in efficiency under competition. The Bell Journal of Economics, v.13, n.2, p. 418-438, 1982.

LORENZ, A.; VEER, T. Once bitten, less shy? The influence of prior misappropriation experience on $\mathrm{R} \& \mathrm{D}$ collaboration. Industry and Innovation, v.26, n.1, p. 31-56, 2019.

LUNDVALL, B-A. National systems of innovation: towards a theory of innovation and interactive learning. London: Pinter, 1992. p. 146-168.

MADDALA, G.S. Introdução à Econometria. 3.ed. Rio de Janeiro: LTC Editora S.A., 2003.

MENDES, C. S.; LOPES, L. S.; GOMES, A. P. Eficiência dos dispêndios em inovação nas indústrias de transformação do Brasil. Revista Brasileira de Inovação, v. 11, n.1, p. 193-218, 2012.

MILESI, D.; PETELSKI, N.; VERRE, V. Innovation and appropriation mechanisms: evidence from Argentine microdata. Technovation, v.33, p.78-87, 2013.

MORCEIRO, P.C. Influência metodológica na desindustrialização brasileira e correções na composição setorial do PIB. TD NEREUS 02-2019. São Paulo: NEREUS-USP, 2019. 
MOURA, D.C. Fatores determinantes do desempenho inovador nas empresas portuguesas: cooperação, capacidade de absorção e políticas públicas. 2016. Covilhã, Portugal, 2016, 261 p. Tese (Doutorado em Economia). Faculdade de Ciências Sociais e Humanas. Universidade da Beira Interior.

MYTELKA, L.; FARINELLI, F. Local clusters, innovation systems and sustained competitiveness: discussion paper. New York: Institute for New Technologies, 2000.

NAQSHBANDI, M. M.; KAUR, S. Effects of managerial ties and appropriability regimes on open innovation. World Applied Sciences Journal, v.15, n.2. p.271278, 2011.

NELSON, R.R.; WINTER, S.G. An evolutionary theory of economic change. Harvard University Press, Cambridge, 1982.

OLANDER, H.; HURMELINNA-LAUKKANEN, P.; VANHALA, M. Mission: possible but sensitive - knowledge protection mechanisms serving different purposes. International Journal of Innovation Management, v.18, n.6, p.1-24, 2014.

OREIRO, J. L.; FEIJÓ, C. A. Desindustrialização: conceituação, causas, efeitos e o caso brasileiro. Revista de Economia Política, v.30, n.2, p. 219-232, 2010.

ORGANISATION FOR ECONOMIC CO-OPERATION AND DEVELOPMENT. OECD. ISIC Rev. 3 Technology intensity definition. OECD Directorate for Science, Technology and Industry. 2011.

ORGANISATION FOR ECONOMIC CO-OPERATION AND DEVELOPMENT. OECD. The measurement of scientific and technological activities: proposed guidelines for collecting and interpreting technological innovation data. Oslo Manual. $3^{\text {rd }}$ ed. Paris: OECD/Eurostat, 2005.

ORGANIZAÇÃO PARA A COOPERAÇÃO E DESENVOLVIMENTO ECONÔMICO. OCDE. Manual de Frascati 2002: medição de atividades científicas e tecnológicas. São Paulo: F-Iniciativas, 2013.

ORGANIZAÇÃO PARA A COOPERAÇÃO E O DESENVOLVIMENTO ECONÔMICO. OCDE. Manual de Oslo: diretrizes para a coleta e interpretação de dados sobre inovação tecnológica. Publicado pela FINEP (Financiadora de Estudos e Projetos). $3^{\text {a }}$ ed. Rio de Janeiro: Finep, 2005.

PARK, K.; KOH, J. Exploring the relationship between perceived pace of technology change and adoption resistance to convergence products. Computers in Human Behavior, v. 69, p. 142-150, 2017.

PAVITT, K. Sectoral patterns of technical change: Towards a taxonomy. Research Policy, v.13, n.6, p. 343-373, 1984. 
PEREIRA, R. M. Relações interorganizacionais e inovação: a importância dos diferentes parceiros e o fator localização. São Paulo, 2017, 109 p. Dissertação (Mestrado). Programa de Pós-graduação em Administração. Departamento de Administração. Faculdade de Economia, Administração e Contabilidade. Universidade de São Paulo.

PINO, F.A. Modelos de decisão binários: uma revisão. Revista de Economia Agrícola, São Paulo, v. 54, n. 1, p. 43-57, jan.-jun. 2007.

PIRES, A.F.E. Determinantes da inovação no desempenho inovador: influencia das fontes de informação, da cooperação e dos investimentos e despesas de inovação. Tomar, Portugal, 2013, 91p. Dissertação (Mestrado) Escola Superior de GestãoInstituto Politécnico de Tomar.

PISANO, G. Profiting from innovation and the intellectual property revolution. Research Policy, v.35, p.1122-1130, 2006.

PODCAMENI, M. G. V. B. Meio ambiente, inovação e competitividade: uma análise da indústria de transformação brasileira com ênfase no setor de combustível. Rio de Janeiro, 2007, 131 p. Dissertação (Mestrado) - Instituto de Economia. Universidade Federal do Rio de Janeiro.

POLANYI, M. The tacit dimension. New York: Doubleday, 1967.

PORTER, M. E. Vantagem competitiva: criando e sustentando um desempenho superior. Rio de Janeiro: Campus, 1989.

PORTER, M. E.; MONTGOMERY, C. Estratégia: a busca da vantagem competitiva. sustentando um desempenho superior. Rio de Janeiro: Campus, 1998.

RITALA, P; HURMELINNA-LAUKKANEN, P. Incremental and radical innovation in coopetition - the role of absorptive capacity and appropriability. Journal of Product Innovation Management, v.30, p.154-169, 2013.

RITALA, P; HURMELINNA-LAUKKANEN, P. What's in it for me? Creating and appropriating value in innovation related coopetition. Technovation, v.29, p.819-828, 2009.

ROBINSON, C.; STOKES, L.; STUIVENWOLD, E.; VAN ARK, B. Industry structure and taxonomies. In: O'Mahony, M. Van Ark, B. EU productivity and competitiveness: An industry perspective. Brussels: European Commission, 2003.

ROTHAERMEL, F. T.; HILL, C. W. L. Technological discontinuities and complementary assets: a longitudinal study of industry and firm performance. Organization Science, v.16, p. 52-70, 2005.

ROTHWELL, R. Towards the fifth-generation innovation process. International Marketing Review, v.11, n.1, p. 7-31, 1994. 
ROUSSEAU, D.M.; WADE-BENZONI, K.A. Linking strategy and human resource practices: how employee and customer contracts are created. Human Resource Management, v,33, n.3, p.463-489, 1994.

RUMELT, R.P. Theory, strategy and entrepreneurship. In: David J. Teece (ed.), The competitive challenge (p. 137-158). New York: Harper \& Row, 1987.

SÁEZ, C. B.; MARCO, T.G.; ANDARRIBAS, E. H. Collaboration in R\&D with universities and research centres: an empirical study of Spanish firms. R\&D Management, v.32, p.321-341, 2002.

SAVIOTTI, P.P. On the dynamics of appropriability, of tacit and of codified knowledge. Research Policy, v.26, p.843-856, 1998.

SCHUMPETER, J. A. Capitalismo, socialismo e democracia. Editado por George Allen e Unwin Ltd.; traduzido por Ruy Jungmann. Rio de Janeiro: Editora Fundo de Cultura, 1961.

SEBRAE. Micro, pequenas e médias empresas. 2018. Disponível em: $<$ http://www.sebrae.com.br/>. Acesso em: 08 abr. 2019.

SEO, H.; CHUNG, Y.; YOON, H. R\&D cooperation and unintended innovation performance: role of appropriability regimes and sectoral characteristics. Technovation, v.66-67, p. 28-42, 2017.

SEVERO, E. A.; DORION, E. C. H.; GUIMARAES, J. C. F. Innovation and environmental sustainability: analysis in Brazilian metal-mechanic industry. International Journal of Innovation and Sustainable Development, v. 11, p. 230-248, 2017.

SILVA, J. A. A questão da desindustrialização no Brasil. Revista Economia \& Tecnologia, v. 10, n. 1, p. 45-75, 2014.

SILVA, M.J.M.; RAPOSO, M.L.B.; FERRÃO, M.E.; MORENO, J.J.J. Relacionamentos externos no âmbito da inovação empresarial: modelo aplicado aos avanços inovadores. Portuguese Journal of Management Sciences, v. X, n.1, p. 5-19, 2005.

SILVA, M.J.A.M. Capacidade inovadora empresarial: estudo dos factores impulsionadores e limitadores nas empresas industriais portuguesas. Covilhã, Portugal, 2003, 262p. Tese (Doutorado em Gestão) - Departamento de Gestão e Economia. Universidade da Beira Interior.

SMIT, T. The appropriability regime as a tool to measure knowledge protection. In: 3rd International Business Administration Bachelor Thesis Conference, July 3, 2014. University of Twente, Faculty of Management and Governance, Enschede, The Netherlands, 2014. 
SORESCU, A. B.; CHANDY, R. K.; PRABHU, J. C. Sources and financial consequences of radical innovation: insights from pharmaceuticals. Journal of Marketing, v..67, p. 82-102, 2003.

SPITHOVENA, A.; TEIRLINCK, P. Internal capabilities, network resources and appropriation mechanisms as determinants of R\&D outsourcing. Research Policy, v.44, p.711-725, 2015.

SUÁREZ, F. F.; LANZOLLA, G. The role of environmental dynamics in building a first mover advantage theory. Academy of Management Review, v. 32, n. 2, p. 377-392, 2007.

SUN, Y.; ZHAI, Y. Mapping the knowledge domain and the theme evolution of appropriability research between 1986 and 2016: a scientometric review. Scientometrics, v. 116, n.1, p, 203-230, 2018.

TEECE, D. J. Profiting from technological innovation: implications for integration, collaboration, licensing and public policy. Research Policy, v.15, n.6, p. $285-305,1986$.

TEECE, D. J. Technological change and the nature of the firm. In: Dosi, G. et al. (org.) Technical change and economic theory. London: Pinter Publishers, 1988.

TEECE, D. J. Competition, cooperation, and innovation: organizational arrangements for regimes of rapid technological progress. Journal of Economic Behavior \& Organization, v.18, p.1-25, 1992.

TEECE, D. J. Reflections on 'Profiting from Innovation'. Research Policy, v. 35, p. 1131-1146, 2006.

TEECE, D. J. Profiting from innovation in the digital economy: standards, complementary assets, and business models in the wireless world. Working Paper Series n.16. 2016. Berkeley, CA: Tusher Center for the Management of Intellectual Capital, 2016.

TETHER, B.S. Who co-operates for innovation, and why? An empirical analysis. Research Policy, v.31, p. 947- 967, 2002.

TIDD, J.; BESSANT, J. Managing innovation: integrating technological, market and organizational change. $6^{\text {th }}$ ed. New York: Wiley, 2018.

TRIPSAS, M. Unraveling the process of creative destruction: complementary assets and incumbent survival in the typesetter industry. Strategic Management Journal, v.18, n.1, p.119-142, 1997.

TUSHMAN, M., ANDERSON, P. Technological discontinuities and organizational environments. Administration Science Quarterly, v. 31, p.439465, 1986. 
VAN DIJK, M. Technological regimes and industrial dynamics: the evidence from Dutch manufacturing. Industrial and Corporate Change, v.9, p.173-194, 2000 .

VEER, T.; LORENZ, A.; BLIND, K. How open is too open? The mitigating role of appropriation mechanisms in $R \& D$ cooperation settings. R\&D Management, v. 46, p.1113-1128, 2016.

VERGARA, S. C. Projetos e relatórios de pesquisa em administração. 4 ed. São Paulo: Atlas, 2003.

VEUGELERS, R.; CASSIMAN, B. R\&D cooperation between firms and universities. Some empirical evidence from Belgian manufacturing. International Journal of Industrial Organization, v. 23, n.5, p.355-379, 2005.

WINTER, S. G. The logic of appropriability: from Schumpeter to Arrow to Teece. LEM Working Paper Series, No. 2006/21, Scuola Superiore Sant'Anna, Laboratory of Economics and Management (LEM), Pisa, 2006.

WU, J. Technological collaboration in product innovation: the role of market competition and sectoral technological intensity. Research Policy, v.41, n.2, p. 489-496, 2012.

ZOBEL, A.K.; LOKSHIN, B.; HAGEDOOM, J. Formal and informal appropriation mechanisms: the role of openness and innovativeness. Technovation, v.59, p.44-54, 2017. 


\section{Apêndice 1 \\ Código-fonte do programa em linguagem SAS utilizado nas regressões logísticas com os microdados da Pintec 2014}

Neste apêndice, apresenta-se o código-fonte do programa em linguagem SAS utilizado nas regressões logísticas com os microdados da Pintec 2014 solicitados em função das questões de pesquisa.

Data Pintec_orig; set caminho.Pintec2014;

RUN ;

data pintec; set Pintec_orig;

/*Apenas empresas que inovaram*/

if INOVAPROJ $=1$;

if $\mathrm{V} 134=1$;

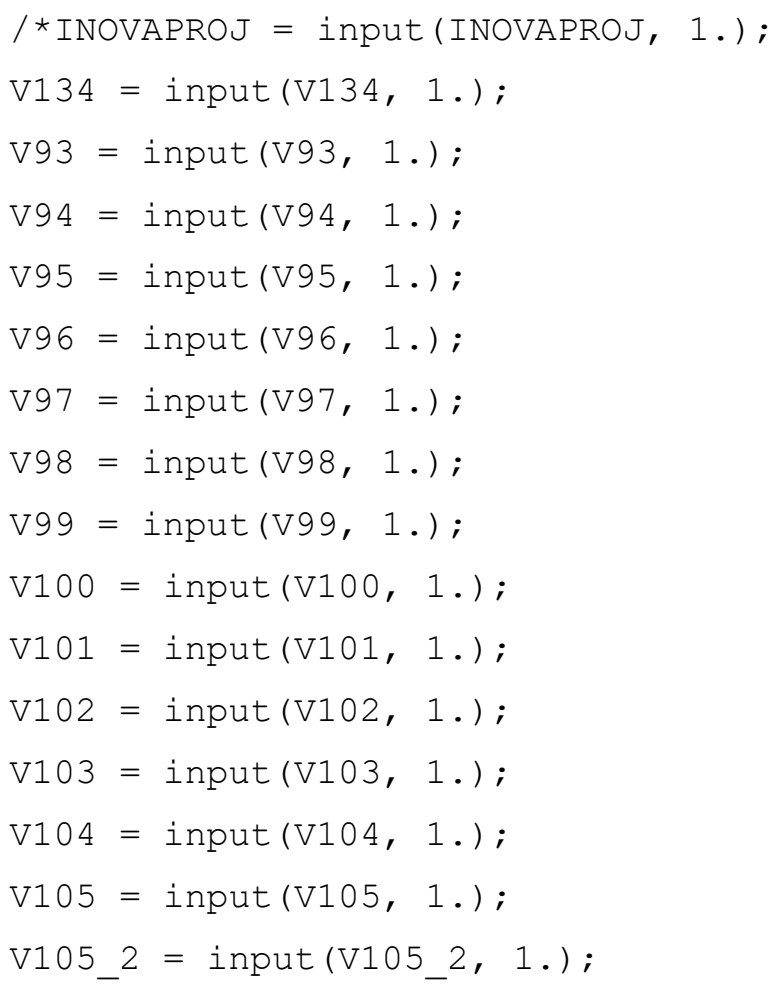









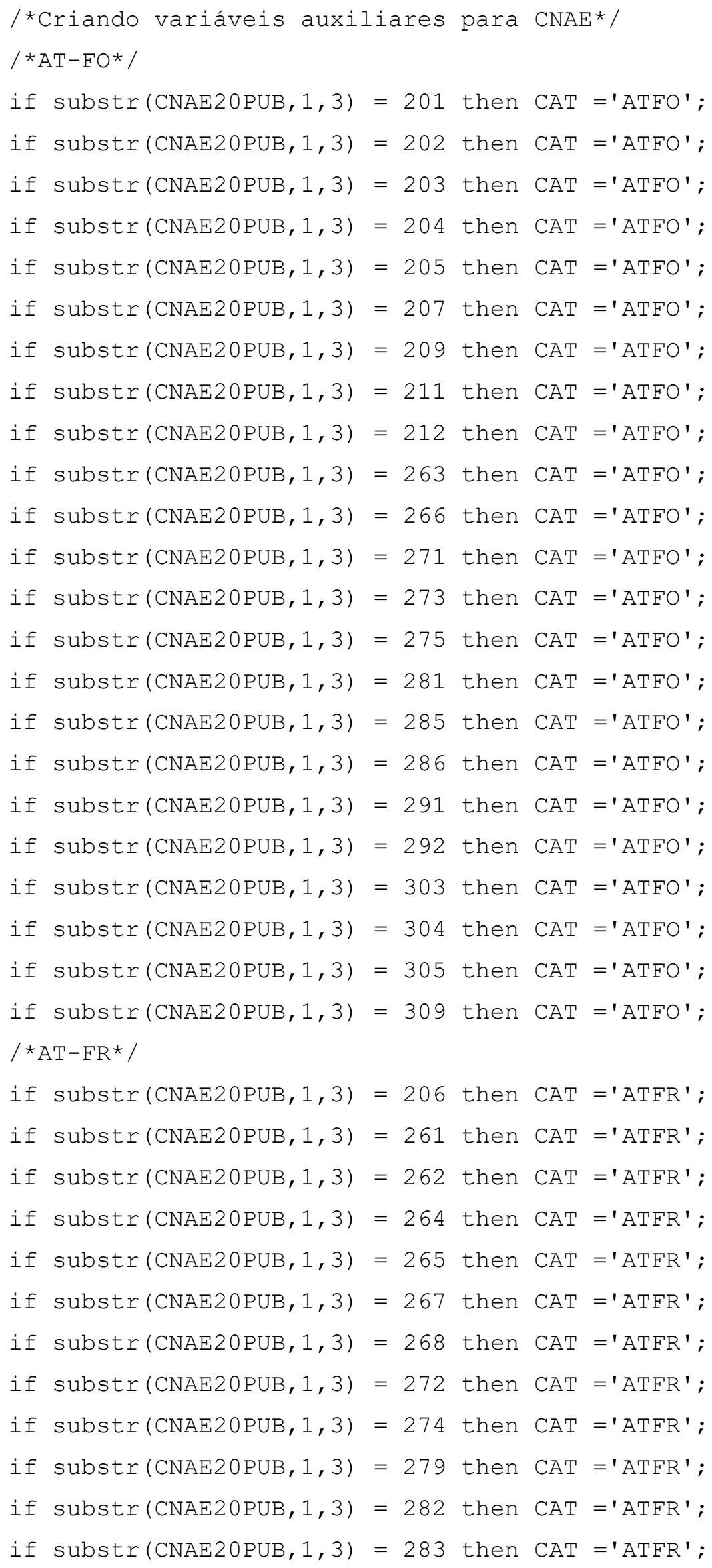




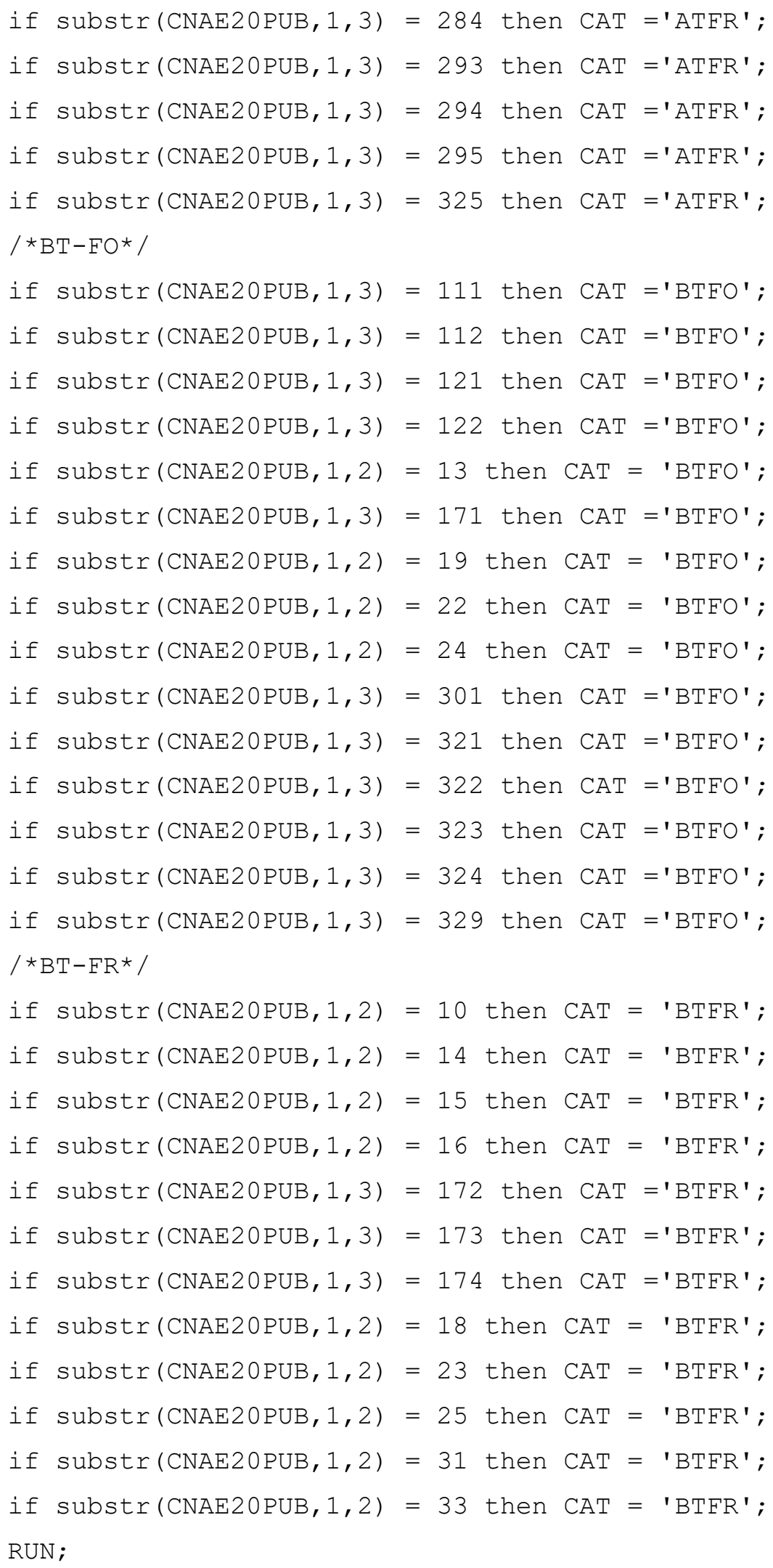




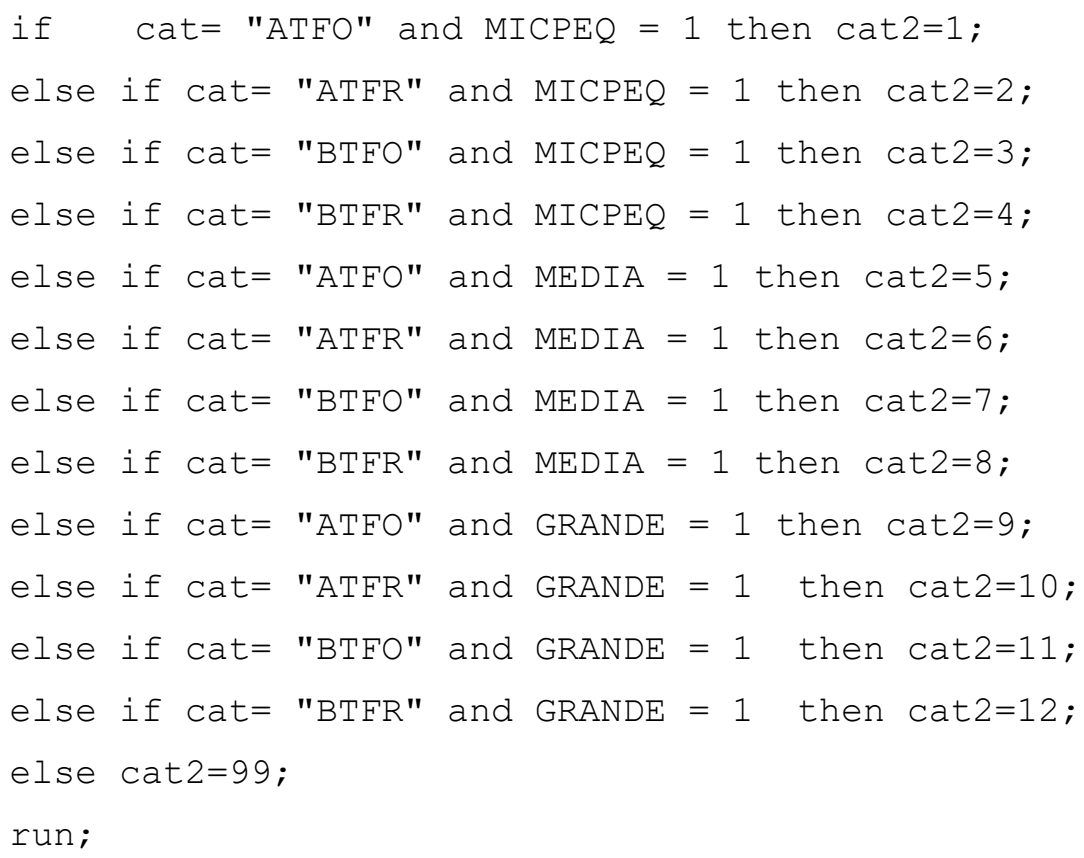

data Pintec; set Pintecintec;

if cat2 =99;

RUN ;

/* FREQUENCIA POR CONJUNTO DE VARIAVEIS CONSTRUidAS* /

proc freq data $=$ Pintec; table cat $2 * M E R C$; run;

proc freq data $=$ Pintec; table cat $2 * \mathrm{PROD}$; run;

proc freq data $=$ Pintec; table cat $2 * A M B I E N$; run;

proc freq data= Pintec; table cat2*SOCIAL; run;

proc freq data = Pintec; table cat $2 *$ REGUL; run;

/* Modelos Logit para cada Variável e categoria*/

/*Variar os 12 filtros*/

omacro cat;

odo cat=1 \%to 12;

ods html

body=" \\Servidor $2 \backslash f \backslash p r o j e t o s \backslash 2018 \backslash 0001727$ _00000232_2018_39-

$\backslash$ modelo1_\&cat..xls";

$/ * \mathrm{MERC} * /$

proc logistic data=Pintec desc outest=betas covout;

model MERC $=$ V135 V136 V137 V138 V139 V140 V141 V141_1

/ selection=stepwise

$$
\begin{aligned}
& \text { slentry }=0.05 \\
& \text { slstay }=0.05
\end{aligned}
$$




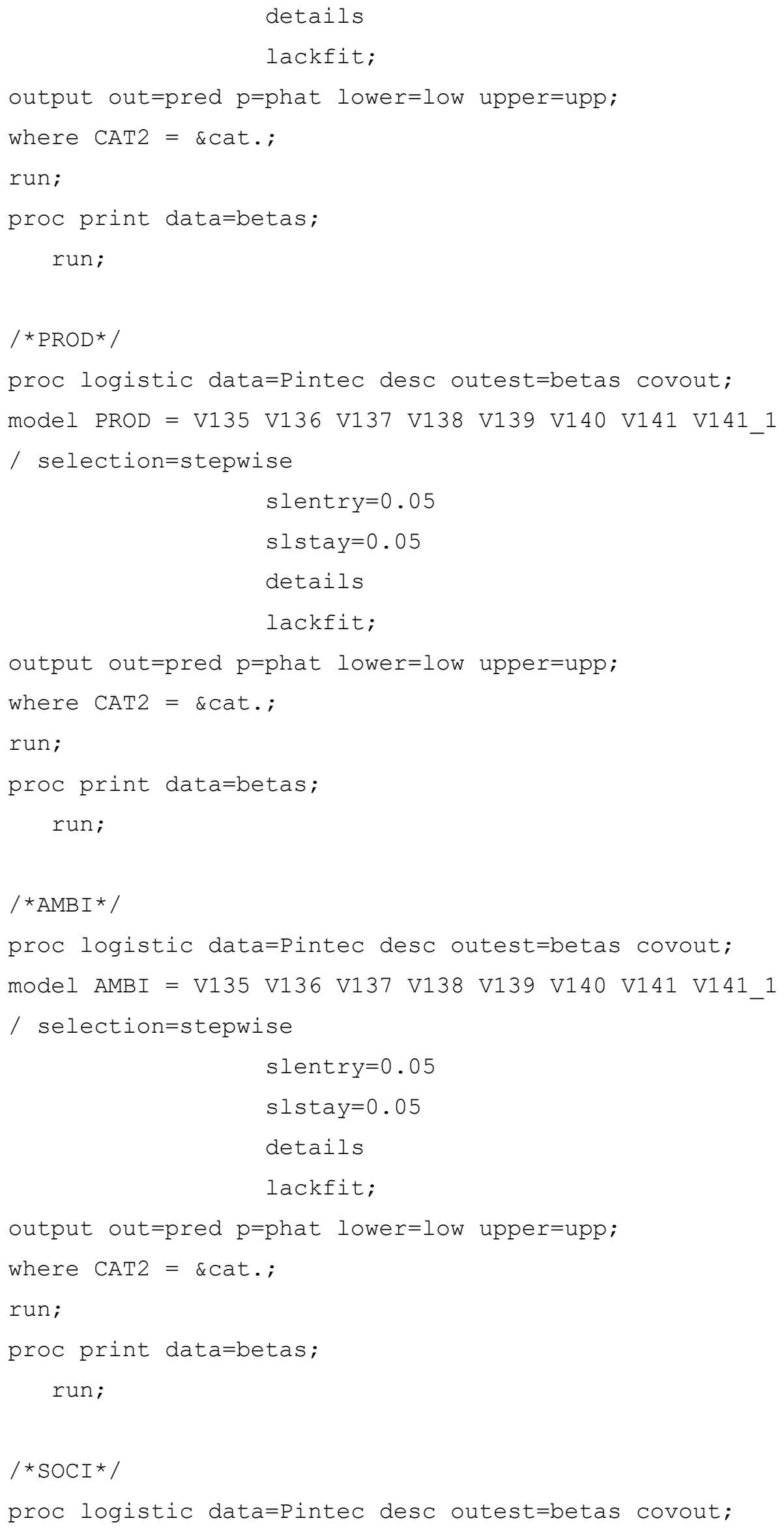


model SOCI $=$ V135 V136 V137 V138 V139 V140 V141 V141_1

/ selection=stepwise

$$
\begin{aligned}
& \text { slentry=0.05 } \\
& \text { slstay=0.05 } \\
& \text { details } \\
& \text { lackfit; }
\end{aligned}
$$

output out=pred $\mathrm{p}=$ phat lower=low upper=upp;

where CAT2 = \&cat.;

run;

proc print data=betas;

run;

/*REGU*/

proc logistic data=Pintec desc outest=betas covout;

model REGU $=$ V135 V136 V137 V138 V139 V140 V141 V141_1

/ selection=stepwise

$$
\begin{aligned}
& \text { slentry=0.05 } \\
& \text { slstay=0.05 } \\
& \text { details } \\
& \text { lackfit; }
\end{aligned}
$$

output out=pred $\mathrm{p}=$ phat lower=low upper=upp ;

where CAT2 = \&cat.;

run;

proc print data=betas;

run;

oend;

omend cat;

ocat;

ods html close. 